U.S. Geological Survey National Water-Quality Assessment Program

Geochemical Evolution Processes and Water-Quality Observations Based on Results of the National WaterQuality Assessment Program in the San Antonio Segment of the Edwards Aquifer, Texas, 1996-2006
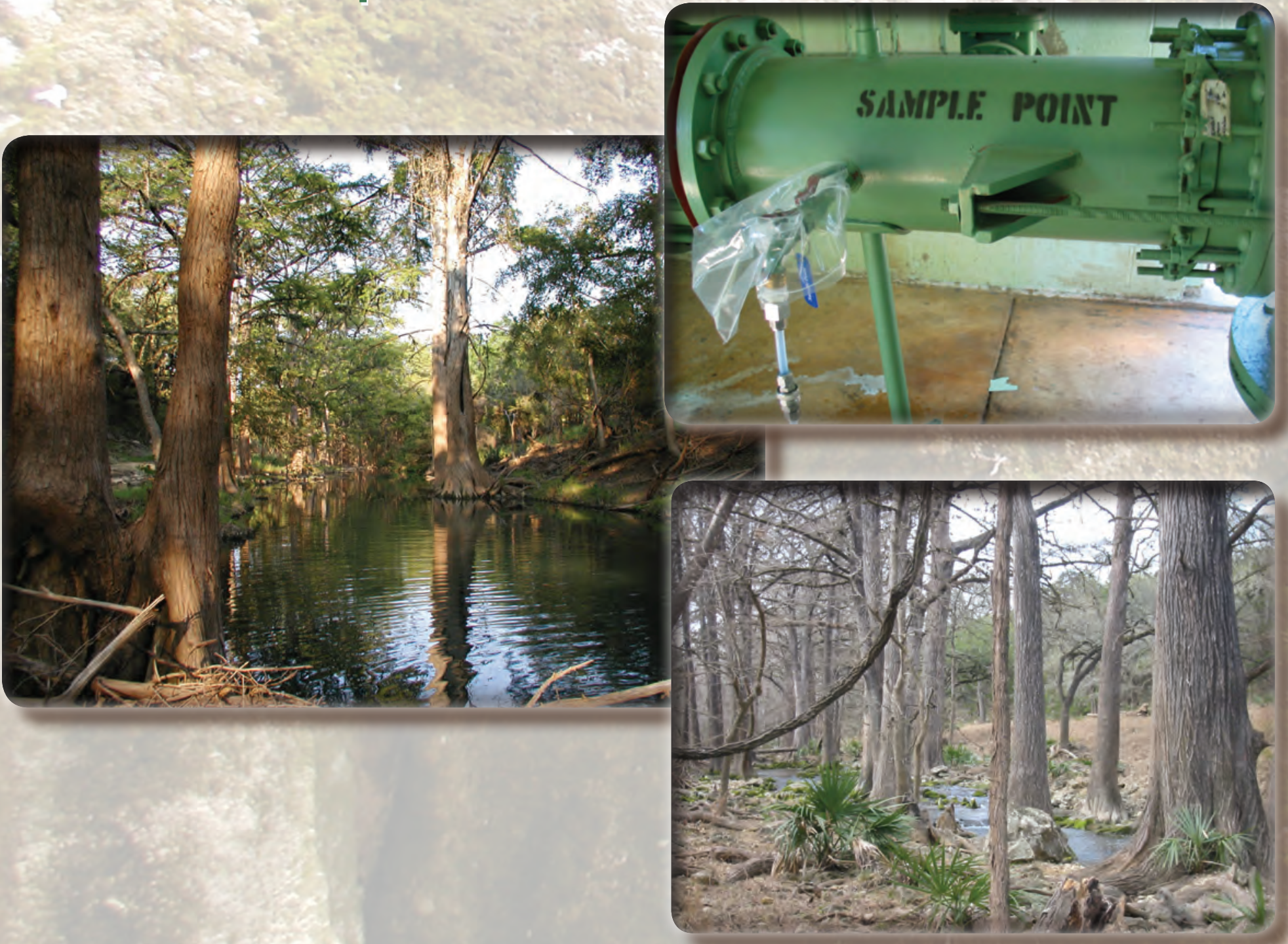

Scientific Investigations Report 2010-5129 


\section{Front cover:}

Top, Public-supply well completed in San Antonio segment of the Ewards aquifer (photograph by Lynne Fahlquist, U.S. Geological Survey).

Left, Surface-water creek, San Antonio segment of the Edwards aquifer (photograph by Libby Stern, U.S. Geological Survey).

Bottom, Surface-water creek, San Antonio segment of the Edwards aquifer (photograph by MaryLynn Musgrove, U.S. Geological Survey).

\section{Back cover:}

Top right, Surface-water creek, San Antonio segment of the Edwards aquifer (photograph by Libby Stern, U.S. Geological Survey).

Top left, Public-supply well completed in San Antonio segment of the Ewards aquifer (photograph by Libby Stern, U.S. Geological Survey).

Bottom right, Surface-water creek, San Antonio segment of the Edwards aquifer (photograph by Libby Stern, U.S. Geological Survey).

Bottom left, Overview of Edwards Plateau, Central Texas (photograph by Libby Stern, U.S. Geological Survey). 


\section{Geochemical Evolution Processes and Water-Quality Observations Based on Results of the National Water-Quality Assessment Program in the San Antonio Segment of the Edwards Aquifer, Texas, 1996-2006}

By MaryLynn Musgrove, Lynne Fahlquist, Natalie A. Houston, Richard J. Lindgren, and Patricia B. Ging

U.S. Geological Survey National Water-Quality Assessment Program

Scientific Investigations Report 2010-5129 


\section{U.S. Department of the Interior \\ KEN SALAZAR, Secretary \\ U.S. Geological Survey \\ Marcia K. McNutt, Director}

U.S. Geological Survey, Reston, Virginia: 2010

This and other USGS information products are available at http://store.usgs.gov/
U.S. Geological Survey
Box 25286 , Denver Federal Center
Denver, CO 80225
To learn about the USGS and its information products visit http://www.usgs.gov/
1-888-ASK-USGS

Any use of trade, product, or firm names is for descriptive purposes only and does not imply endorsement by the U.S. Government.

Although this report is in the public domain, permission must be secured from the individual copyright owners to reproduce any copyrighted materials contained within this report.

Suggested citation:

Musgrove, M., Fahlquist, L., Houston, N.A., Lindgren, R.J., and Ging, P.B., 2010, Geochemical evolution processes and water-quality observations based on results of the National Water-Quality Assessment Program in the San Antonio segment of the Edwards aquifer, 1996-2006: U.S. Geological Survey Scientific Investigations Report 2010-5129, 93 p. (Appendixes available online at http://pubs.usgs.gov/sir/2010/5129/.) 


\section{Acknowledgments}

The authors thank Bruce D. Lindsey and Barbara J. Mahler, U.S. Geological Survey, and Geary Schindel, Edwards Aquifer Authority, for their helpful technical reviews of this report. 
Blank Page 


\section{Contents}

Abstract
Introduction
Purpose and Scope
Hydrogeologic Setting
Variability in Water Quality in Karst Aquifers
Methods
Overview of Geochemical Data
Geochemical Evolution Processes
Major/Trace Element Ratios
Strontium Isotopes
Salinity Sources
Radon

Appendixes (available online at http://pubs.usgs.gov/sir/2010/5129/)

1 Site information for wells and springs sampled for National Water-Quality Assessment studies, San Antonio segment of the Edwards aquifer, south-central Texas, 1996-2006

2. Physicochemical measurements for groundwater samples collected for National Water-Quality Assessment studies, San Antonio segment of the Edwards aquifer, south-central Texas, 1996-2006

3. Dissolved solids and major ion measurements for groundwater samples collected for National Water-Quality Assessment studies, San Antonio segment of the Edwards aquifer, south-central Texas, 1996-2006

4. Nutrient measurements for groundwater samples collected for National WaterQuality Assessment studies, San Antonio segment of the Edwards aquifer, southcentral Texas, 1996-2006

5. Trace element measurements for groundwater samples collected for National Water-Quality Assessment studies, San Antonio segment of the Edwards aquifer, south-central Texas, 1996-2006 
6. Stable isotope and radionuclide measurements for groundwater samples collected for National Water-Quality Assessment studies, San Antonio segment of the Edwards aquifer, south-central Texas, 1996-2006

7. Volatile organic and fuel oxygenate compounds for groundwater samples collected for National Water-Quality Assessment studies, San Antonio segment of the Edwards aquifer, south-central Texas, 1996-2006

8A. Soluble pesticide compounds for groundwater samples collected for National Water-Quality Assessment studies, San Antonio segment of the Edwards aquifer, south-central Texas, 1996-2006

8B. Polar pesticide compounds for groundwater samples collected for National Water-Quality Assessment studies, San Antonio segment of the Edwards aquifer, south-central Texas, 1996-2006

8C. Acetamide, glyphosate, amino-methyl-phosphoric acid, and glufosinate pesticide compounds for groundwater samples collected for National Water-Quality Assessment studies, San Antonio segment of the Edwards aquifer, south-central Texas, 1996-2006

9. Wastewater indicator compounds for groundwater samples collected for National Water-Quality Assessment studies, San Antonio segment of the Edwards aquifer, south-central Texas, 1996-2006

10. Apparent age tracer concentrations and piston-flow model apparent ages for groundwater samples collected for National Water-Quality Assessment studies, San Antonio segment of the Edwards aquifer, south-central Texas, 1998 and 2006

11. Summary of particle-track results for conduit- and diffuse-flow models, San Antonio segment of the Edwards aquifer, south-central Texas

\section{Figures}

1. Map showing hydrogeologic setting and location of wells (shallow/urban unconfined, unconfined, and confined) and springs (confined) sampled for water quality in the San Antonio segment of the Edwards aquifer, south-central Texas, 1996-2006

2. Diagrammatic north-northwest to south-southeast section showing hydrogeologic framework and generalized groundwater flow directions, Edwards Plateau to Gulf Coastal Plain, San Antonio region, Texas

3. Graphs showing time series (1996-2006) of (A) Comal Springs discharge and Bexar County index well (J-17) water-level altitude, and (B) San Antonio rainfall

4-5. Maps showing:

4. Regional land use and location of wells (shallow/urban unconfined, unconfined, and confined) and springs (confined) sampled for water quality in the San Antonio segment of the Edwards aquifer, south-central Texas, 1996-2006

5. Surface-water sites sampled for water quality in or near the Edwards aquifer recharge zone, San Antonio segment of the Edwards aquifer, south-central Texas, 1996-2007

6. Trilinear diagram showing relations between major cations and anions in groundwater collected from shallow/urban unconfined, unconfined, and confined parts of the San Antonio segment of the Edwards aquifer, south-central Texas, 1996-2006 
7-10. Graphs showing:

7. Relation between magnesium to calcium and strontium to calcium (molar ratios) for groundwater samples collected from shallow/urban unconfined, unconfined, and confined parts of the San Antonio segment of the Edwards aquifer, south-central Texas, 1996-2006; (A) full scale, and (B) shaded region in (A)

8. Relation between magnesium to calcium (molar ratio) and dolomite mineral saturation index for groundwater samples collected from shallow/urban unconfined, unconfined, and confined parts of the San Antonio segment of the Edwards aquifer, south-central Texas, 1996-2006

9. Relation between $(A)$ magnesium to calcium (molar ratio) and calcium concentration, and (B) strontium to calcium (molar ratio $\times 10^{3}$ ) and calcium concentration for groundwater samples collected from shallow/urban unconfined, unconfined, and confined parts of the San Antonio segment of the Edwards aquifer, 1996-2006

10. Relation between (A) strontium-87/strontium- 86 isotopic ratio and magnesium to calcium (molar ratio) and (B) strontium-87/strontium-86 isotopic ratio and strontium to calcium (molar ratio $\times 10^{3}$ ) for groundwater samples collected from shallow/urban unconfined, unconfined, and confined parts of the San Antonio segment of the Edwards aquifer, south-central Texas, 1996-2006

11. Graph of $(A)$ relation between chloride concentration and delta deuterium for groundwater samples collected from shallow/urban unconfined, unconfined, and confined parts of the San Antonio segment of the Edwards aquifer, south-central Texas, 1996-2006, and (B) location map of sample sites associated with mixing trendlines shown in (A)

12-19. Graphs showing:

12. Relation between (A) sulfate to chloride ratio and sulfate concentration, and (B) magnesium to sodium ratio and magnesium concentration for groundwater samples collected from shallow/urban unconfined, unconfined, and confined parts of the San Antonio segment of the Edwards aquifer, southcentral Texas, 1996-2006

13. Relation between magnesium to calcium (molar ratio) and radon-222 for groundwater samples collected from unconfined and confined parts of the San Antonio segment of the Edwards aquifer, south-central Texas, 1996-2006 ...26

14. Relation between well depth and (A) radon-222 and (B) magnesium to calcium (molar ratio) for groundwater samples collected from shallow/urban unconfined, unconfined, and confined parts of the San Antonio segment of the Edwards aquifer, south-central Texas, 1996-2006

15. Relation between nitrate concentration and specific conductance for groundwater samples collected from shallow/urban unconfined, unconfined, and confined parts of the San Antonio segment of the Edwards aquifer, southcentral Texas, 1996-2006

16. (A) Time series of nitrate concentration in Comal Springs discharge, and (B) relation between nitrate concentration at Comal Springs and Comal Springs discharge, San Antonio segment of the Edwards aquifer, southcentral Texas, 1938-2006

17. Time series of chloride concentration in Comal Springs discharge, San Antonio segment of the Edwards aquifer, south-central Texas, 1938-2006

18. (A) Detection frequency and (B) median concentration of the most frequently detected anthropogenic contaminants in groundwater samples collected from shallow/urban unconfined, unconfined, and confined parts of the San Antonio segment of the Edwards aquifer, south-central Texas, 19962006 
19. Most frequently detected anthropogenic contaminants, detection frequency in (A) shallow/urban unconfined category samples collected in 1998 and 2006, and (B) unconfined category samples collected in 1996 and 2006; median concentration in (C) shallow/urban unconfined category samples collected in 1998 and 2006, and (D) unconfined category samples collected in 1996 and 2006, San Antonio segment of the Edwards aquifer, south-central Texas

20. Map showing location of five shallow/urban unconfined monitoring wells with time-series data, and regional wells (shallow/urban unconfined, unconfined, and confined) and springs (confined) sampled for water quality in the San Antonio segment of the Edwards aquifer, south-central Texas, 1996-2006

21-24. Graphs showing:

21. Time-series comparison of $(A)$ depth to water in five shallow/urban unconfined category monitoring wells; (B) daily rainfall at San Antonio International Airport, and (C) discharge at Comal Springs, San Antonio segment of the Edwards aquifer, south-central Texas, 1998-2006

22. Time series comparison of $(A)$ nitrate concentration, $(B)$ atrazine concentration, (C) magnesium to calcium (molar ratio) for five shallow/urban unconfined category monitoring wells, and (D) discharge at Comal Springs, San Antonio segment of the Edwards aquifer, south-central Texas, 19982006

23. Relation between Comal Springs discharge and (A) nitrate concentration, (B) atrazine concentration, and (C) magnesium to calcium (molar ratio) for five shallow/urban unconfined category monitoring wells, San Antonio segment of the Edwards aquifer, south-central Texas, 1998-2006

24. Time-series comparison of depth to water and (A) nitrate concentration, (B) atrazine concentration, and (C) magnesium to calcium (molar ratio) for shallow/urban unconfined category monitoring well AY-28-28-314, San Antonio segment of the Edwards aquifer, south-central Texas, 1998-2006 .40

25. Map showing location of unconfined and confined category wells with historical water-quality data, San Antonio segment of the Edwards aquifer, south-central Texas, 1957-2006

26-29. Graphs showing:

26. Comparison of (A) time series of magnesium to calcium (molar ratio) for 13 wells (two unconfined category and 11 confined category); (B) historical relation between Comal Springs discharge and depth to water at well TD-69-46-601 (confined category, Medina County); and (C) time series of magnesium to calcium (molar ratio) (note inverted scale) and depth to water at well TD-69-46-601 (confined category, Medina County), San Antonio segment of the Edwards aquifer, south-central Texas, 1970-2007

27. Relation between groundwater apparent ages for chlorofluorocarbon (CFC) (CFC-12 or CFC-113) and sulfur hexafluoride tracers for groundwater samples collected from shallow/urban unconfined category wells, San Antonio segment of the Edwards aquifer, south-central Texas, 2006 .46

28. Relation between magnesium to calcium (molar ratio) and apparent age for groundwater samples collected from shallow/urban unconfined and unconfined parts of the San Antonio segment of the Edwards aquifer, southcentral Texas, (A) 1998 and (B) 2006

29. Comparison of apparent ages determined from geochemical age tracers (sulfur hexafluoride, chlorofluorocarbons, and tritium) for groundwater samples collected from shallow/urban unconfined, unconfined, and confined parts of the San Antonio segment of the Edwards aquifer, south-central Texas, 1996-2006, with mean particle-track travel-time estimates derived from conduit-flow and diffuse-flow models for the Edwards aquifer 


\section{Tables}

1. Summary of constituents by group for groundwater samples collected for National Water-Quality Assessment studies, San Antonio segment of the Edwards aquifer, south-central Texas, 1996-2006

2. Surface-water sites sampled for water quality in or near the Edwards aquifer recharge zone, San Antonio segment of the Edwards aquifer, south-central Texas, 1996-2007

3. Summary statistics by group for field, physicochemical, inorganic, radiogenic, and stable isotope constituents analyzed in groundwater samples collected from the San Antonio segment of the Edwards aquifer, south-central Texas, 1996-2006

4. Summary statistics by group for organic constituents analyzed in groundwater samples collected from the San Antonio segment of the Edwards aquifer, southcentral Texas, 1996-2006

5. Unconfined and confined category wells with historical water-quality data, San Antonio segment of the Edwards aquifer, south central Texas, 1957-2006

6. Summary of age tracer data and interpreted apparent ages for groundwater samples collected from the San Antonio segment of the Edwards aquifer, southcentral Texas, 1996-2006

7. Summary of model-calculated particle-track information for groundwater sample categories, San Antonio segment of the Edwards aquifer, south-central Texas 


\section{Conversion Factors, Datums, Water-Quality Units, Abbreviations, and Isotope Unit Explanations}

\section{Inch/Pound to SI}

\begin{tabular}{lcl}
\hline \multicolumn{1}{c}{ Multiply } & By & \multicolumn{1}{c}{ To obtain } \\
\hline foot (ft) & Length & \\
inch (in.) & 0.3048 & meter $(\mathrm{m})$ \\
mile (mi) & 25.4 & millimeter $(\mathrm{mm})$ \\
\hline & 1.609 & kilometer $(\mathrm{km})$ \\
\hline square mile $\left(\mathrm{mi}^{2}\right)$ & Area & \\
\hline & 2.590 & square kilometer $\left(\mathrm{km}^{2}\right)$ \\
\hline cubic foot per second $\left(\mathrm{ft}^{3} / \mathrm{s}\right)$ & Flow rate & \\
foot per day $(\mathrm{ft} / \mathrm{d})$ & 0.02832 & cubic meter per second $\left(\mathrm{m}^{3} / \mathrm{s}\right)$ \\
& 0.3048 & \\
\hline picocurie per liter $(\mathrm{pCi} / \mathrm{L})$ & Radioactivity & becquerel per liter $(\mathrm{Bq} / \mathrm{L})$ \\
\hline
\end{tabular}

\section{SI to Inch/Pound}

\begin{tabular}{lll}
\hline \multicolumn{1}{c}{ Multiply } & By & \multicolumn{1}{c}{ To obtain } \\
\hline centimeter $(\mathrm{cm})$ & Length & \\
kilometer $(\mathrm{km})$ & 0.39370 & inch (in.) \\
meter $(\mathrm{m})$ & 0.6214 & mile (mi) \\
\hline & 3.281 & foot (ft) \\
\hline meter per day $(\mathrm{m} / \mathrm{d})$ & Flow rate & foot per day $(\mathrm{ft} / \mathrm{d})$ \\
\hline
\end{tabular}

\section{Datums}

Horizontal coordinate information is referenced to the North American Datum of 1983 (NAD 83). Vertical coordinate information is referenced to the North American Vertical Datum of 1988 (NAVD 88).

Altitude, as used in this report, refers to distance above the vertical datum.

\section{Water-Quality Units}

Chemical concentrations are reported in milligrams per liter ( $\mathrm{mg} / \mathrm{L})$, micrograms per liter $(\mu \mathrm{g} / \mathrm{L})$, and milliequivalents per liter (meq/L). Milligrams per liter and micrograms per liter are units expressing the concentration of chemical constituents in solution as weight of solute (milligrams or micrograms) per unit volume (liter) of water. Milliequivalents per liter is a unit expressing the concentration of chemical constituents in solution as $1 / 1000$ the molecular weight, in milligrams, divided by the valence of one molecule of the constituent per unit volume (liter) of water. Specific conductance is given in microsiemens per centimeter at 25 degrees Celsius $\left(\mu \mathrm{S} / \mathrm{cm}\right.$ at $\left.25^{\circ} \mathrm{C}\right)$. 


\section{Abbreviations}

femtoMol/kg, femtomoles per kilogram

$\mu \mathrm{g} / \mathrm{L}$, micrograms per liter

$\mu \mathrm{S} / \mathrm{cm}$, microsiemens per centimeter at 25 degrees Celsius

$\mathrm{meq} / \mathrm{L}$, milliequivalents per liter

$\mathrm{mg} / \mathrm{L}$, milligrams per liter

NTRU, nephelometric turbidity ratiometric units

$\mathrm{pCi} / \mathrm{L}$, picocurie per liter

$\mathrm{pk} / \mathrm{kg}$, picograms per kilogram

$\mathrm{pMol} / \mathrm{kg}$, picomoles per kilogram

ppm, parts per million

pptv, parts per trillion per volume

SI, saturation index

TU, tritium units

\section{Isotope Unit Explanations}

Per mil (\%): A unit expressing the ratio of isotope abundances of an element in a sample to those of a standard material. Per mil units are equivalent to parts per thousand. Stable-isotope ratios are computed as follows (Kendall and McDonnell, 1998):

$$
\delta X=\left\{\left(R_{\text {sample }}-R_{\text {standard }}\right) / R_{\text {standard }}\right\} \times 1,000 \text {, }
$$

where

$\delta$ is the "delta" notation,

$\mathrm{X}$ is the heavier stable isotope, and

$\mathrm{R}$ is the ratio of the heavier, less abundant isotope to the lighter, stable isotope in a sample or standard.

The $\delta$ values for stable-isotope ratios discussed in this report are referenced to the following standard materials:

\begin{tabular}{ccc}
\hline Element & R & \multicolumn{1}{c}{ Standard identity and reference } \\
\hline hydrogen & hydrogen-2/hydrogen-1 & Vienna Standard Mean Ocean Water (VSMOW) (Fritz and \\
& & Fontes, 1980) \\
oxygen & oxygen-18/oxygen-16 & $\begin{array}{c}\text { Vienna Standard Mean Ocean Water (VSMOW) (Fritz and } \\
\text { Fontes, 1980) }\end{array}$ \\
\hline
\end{tabular}


Blank Page 


\title{
Geochemical Evolution Processes and Water-Quality Observations Based on Results of the National Water- Quality Assessment Program in the San Antonio Segment of the Edwards Aquifer, Texas, 1996-2006
}

\author{
By MaryLynn Musgrove, Lynne Fahlquist, Natalie A. Houston, Richard J. Lindgren, and Patricia B. Ging
}

\section{Abstract}

As part of the National Water-Quality Assessment Program, the U.S. Geological Survey collected and analyzed groundwater samples during 1996-2006 from the San Antonio segment of the Edwards aquifer of central Texas, a productive karst aquifer developed in Cretaceous-age carbonate rocks. These National Water-Quality Assessment Program studies provide an extensive dataset of groundwater geochemistry and water quality, consisting of 249 groundwater samples collected from 136 sites (wells and springs), including (1) wells completed in the shallow, unconfined, and urbanized part of the aquifer in the vicinity of San Antonio (shallow/urban unconfined category), (2) wells completed in the unconfined (outcrop area) part of the regional aquifer (unconfined category), and (3) wells completed in and springs discharging from the confined part of the regional aquifer (confined category). This report evaluates these data to assess geochemical evolution processes, including local- and regional-scale processes controlling groundwater geochemistry, and to make water-quality observations pertaining to sources and distribution of natural constituents and anthropogenic contaminants, the relation between geochemistry and hydrologic conditions, and groundwater age tracers and travel time. Implications for monitoring water-quality trends in karst are also discussed.

Geochemical and isotopic data are useful tracers of recharge, groundwater flow, fluid mixing, and water-rock interaction processes that affect water quality. Sources of dissolved constituents to Edwards aquifer groundwater include dissolution of and geochemical interaction with overlying soils and calcite and dolomite minerals that compose the aquifer. Geochemical tracers such as magnesium to calcium and strontium to calcium ratios and strontium isotope compositions are used to evaluate and constrain progressive fluidevolution processes. Molar ratios of magnesium to calcium and strontium to calcium in groundwater typically increase along flow paths; results for samples of Edwards aquifer groundwater show an increase from shallow/urban unconfined, to unconfined, to confined groundwater categories. These differences are consistent with longer residence times and greater extents of water-rock interaction controlling fluid compositions as groundwater evolves from shallow unconfined groundwater to deeper confined groundwater. Results for stable isotopes of hydrogen and oxygen indicate specific geochemical processes affect some groundwater samples, including mixing with downdip saline water, mixing with recent recharge associated with tropical cyclonic storms, or mixing with recharge water than has undergone evaporation. The composition of surface water recharging the aquifer, as well as mixing with downdip water from the Trinity aquifer or the saline zone, also might affect water quality.

A time-series record (1938-2006) of discharge at Comal Springs, one of the major aquifer discharge points, indicates an upward trend for nitrate and chloride concentrations, which likely reflects anthropogenic activities. A small number of organic contaminants were routinely or frequently detected in Edwards aquifer groundwater samples. These were the pesticides atrazine, its degradate deethylatrazine, and simazine; the drinking-water disinfection byproduct chloroform; and the solvent tetrachloroethene. Detection of these contaminants was most frequent in samples of the shallow/urban unconfined groundwater category and least frequent in samples of the unconfined groundwater category. Results indicate that the shallow/urban unconfined part of the aquifer is most affected by anthropogenic contaminants and the unconfined part of the aquifer is the least affected. The high frequency of detection for these anthropogenic contaminants aquifer-wide and in samples of deep, confined groundwater indicates that the entire aquifer is susceptible to water-quality changes as a result of anthropogenic activities.

Like many karst aquifers, the Edwards aquifer responds rapidly to changes in hydrologic conditions, with accompanying changes in water-level altitudes, spring discharge rates, and water quality. Samples of groundwater were collected one or two times during the study period (1996-2006) from most sites, a sampling frequency which does not allow for evaluation of temporal trends. Five of the shallow/urban unconfined 
category wells had a higher frequency of sampling, with a total of eight samples collected from each well over the 10-year study period. These data indicate that changes in hydrologic conditions, as demonstrated by changes in rainfall, aquifer recharge, water-level altitudes in wells, and springflow at major aquifer discharge points, affect water quality. Variations in selected dissolved constituents or ratios of dissolved constituents (atrazine, nitrate, and magnesium to calcium molar ratios) at these five wells provide insight into the sources and transport of dissolved constituents and contaminants in the aquifer, and the relation between water quality and hydrologic conditions. These results suggest that atrazine enters the aquifer with surface-water recharge, whereas background nitrate concentrations in the aquifer are diluted by surfacewater recharge. Higher nitrate concentrations and magnesium to calcium ratios occur in conjunction with lower water-level altitudes during drier hydrologic conditions.

Geochemical age tracers, including tritium, chlorofluorocarbons, and sulfur hexafluoride, were measured in a majority of the groundwater samples. Results for apparent groundwater ages indicated that samples of groundwater from the Edwards aquifer are dominated by young (that is, water recharged within approximately the past 50 years) and (or) modern water (in this report, samples with apparent ages that belong to the present day, that is within 10 years of the time of sampling), with extensive groundwater mixing. These results are consistent with the regional hydrogeology and previous studies that document a large range of travel times and groundwater mixing. Apparent ages for all uncontaminated groundwater samples (many of the chlorofluorocarbon and sulfur hexafluoride results indicated that samples were contaminated by non-atmospheric sources of these tracers) ranged from 1 to 52 years, with a median of 20 years. These results are based on a piston-flow model, which might not adequately describe the range of ages in a mixed sample, which is a relevant consideration for karst aquifers such as the Edwards aquifer. In spite of uncertainties in age interpretation, age tracers provide insight into how changing hydrologic conditions affect groundwater recharge and mixing processes. Apparent age results for samples collected from the relatively shallow unconfined part of the aquifer were younger than those for samples collected from the deeper unconfined part of the aquifer.

A comparison of apparent groundwater ages with calculated particle-track travel times from existing hydrogeologic models indicates that these flow models do not accurately represent the fast-flow (conduit-dominated) component of this karst aquifer. The model results, however, do show a progression toward longer travel times from the unconfined to the confined parts of the aquifer, which is consistent with geochemical interpretations and aquifer hydrogeology. The results of this evaluation of NAWQA data have implications for the design of monitoring programs in karst aquifers. When monitoring programs are intended to provide the data necessary to assess long-term trends and increase understanding of karst aquifer functioning, time scales of hydrologic and geochemical variability need to be carefully considered.

\section{Introduction}

Forty percent of the Nation's groundwater used for drinking water is obtained from karst aquifers (Quinlan and Ewers, 1989; Karst Waters Institute, 2008). Karst groundwater systems are subject to rapid changes in flow and discharge rates, water-level altitudes, and water quality, and as a result, are susceptible to contamination (White, 1988). The San Antonio segment of the Edwards aquifer in south-central Texas, one of the most productive karst aquifers in the world, is the sole source water supply for more than 2 million people in a rapidly urbanizing region (Sharp and Banner, 1997; U.S. Environmental Protection Agency, 2006). The San Antonio segment of the Edwards aquifer is in a part of Texas characterized by numerous sinkholes, caves, and losing streams that supply recharge to the aquifer and provide direct interaction between surface water and groundwater (Sharp and Banner, 1997). Springs issuing from the Edwards aquifer provide habitat for several threatened and endangered species (Edwards Aquifer Research and Data Center, 2010). An understanding of the relation between variability in water quality and hydrologic conditions on different time scales including geochemical evolution processes, spatial and temporal variability of groundwater geochemistry, and natural and anthropogenic effects on water quality is necessary for resource management as well as for sustainability of springflow for threatened and endangered species habitat.

Karst aquifers are composed of soluble host rocks, usually carbonates, that have dissolved preferentially to form large voids and conduits (White, 1988). As a result, karst aquifers are extremely heterogeneous, with a large range of porosity and permeability spanning many orders of magnitude. Aquifer systems with these features are susceptible to contamination because of the rapid transport of groundwater through high porosity voids and conduits with little opportunity for subsurface filtration, sorption, or degradation of dissolved or particulate constituents (White, 1988). Karst aquifer permeability ranges from matrix permeability, characterized by high storage and low transmissivity, to conduit permeability, characterized by low storage and high transmissivity (Schuster and White, 1971; Atkinson, 1977). Karst sometimes is considered in terms of a triple porosity/permeability model that includes matrix permeability (intergranular permeability of the unfractured rock), fracture permeability (permeability associated with joints and bedding plane partings, which are sometimes enlarged by dissolution), and conduit permeability (permeability associated with pipe-like openings ranging from 1 centimeter to tens of meters (White, 2002). Most groundwater storage occurs within the aquifer matrix, but most transport occurs within conduits, which often dominate groundwater flow where present (White, 2002). Recharge to karst aquifers occurs as direct infiltration into karst features such as sinkholes and fractures (focused recharge), and as distributed infiltration into the rock matrix (diffuse recharge); the proportion of focused and diffuse recharge can vary greatly in time and space depending on a number of variables (Worthington, 
2003; Mahler and others, 2006). In wells and springs that are dominantly affected by conduit flow, physicochemical properties, concentrations of geochemical constituents, and discharge (springs) or water-level altitudes (wells) can change rapidly (minutes to hours to days) following rainfall and aquifer recharge. In contrast, water-level altitudes in wells that are dominantly affected by matrix flow might show little response to recharge events and less variability in physicochemical properties and geochemistry. Natural discharge in karst aquifers often occurs through large springs, which represent a composite of all water moving through the aquifer; as a result, variations in spring discharge, physicochemical constituents, and geochemistry provide insight into karst aquifer hydrogeology (White, 2002).

\section{Purpose and Scope}

The combined results of previous National Water-Quality Assessment (NAWQA) studies done in the San Antonio segment of the Edwards aquifer (1996-2006) provide an extensive dataset for analysis. The purpose of this report is to evaluate those previously collected and quality-assured data to assess geochemical evolution processes and to make water-quality observations. One of the long-term goals of the NAWQA Program is to assess status and trends in the quality of the Nation's water resources. Toward those goals, this report evaluates (1) hydrologic processes in the Edwards aquifer such as mineral-solution reactions and groundwater geochemical evolution, (2) spatial and temporal (time-series) data for natural and anthropogenic constituents, (3) the relation between geochemistry and water quality with hydrologic conditions, (4) the utility of geochemical age tracers, and (5) a comparison of age-tracer data with existing flow models, to develop an integrated understanding of karst and aquifer processes. Implications for monitoring water-quality trends in karst are also discussed. Given the large number of analytical constituents that have been analyzed for samples of groundwater collected throughout the Edwards aquifer, this report presents an overview of variability in groundwater geochemistry and water quality, and controlling processes in the San Antonio segment of the aquifer.

\section{Background and Previous Studies}

Knowledge of water resources and water quality is important for reasons of human and aquatic health as well as for costs and concerns associated with water management. In 1991, the U.S. Geological Survey (USGS) implemented the NAWQA Program to characterize, in a nationally consistent manner, water quality of major surface-water and groundwater resources of the Nation, to determine natural and human factors that affect water quality, and to define trends in water quality (Gilliom and others, 1995). The NAWQA Program includes efforts to systematically assess the occurrence and distribution of natural and anthropogenic compounds in aquifers of regional importance. Another component of the NAWQA Program is to evaluate trends in water quality in these aquifers. Toward these ends, the NAWQA Program collected and analyzed 249 groundwater samples from 136 sites during 1996-2006 throughout the San Antonio segment of the Edwards aquifer in the south-central Texas (SCTX) study unit. The study unit includes the extent of the San Antonio segment of the aquifer, which is the area of focus of this report (fig. 1).

Previous studies of the Edwards aquifer provide insight into the hydrology and geochemistry of this system. Geochemical processes that affect groundwater geochemistry include interaction with overlying soils, mineral-solution reactions, and mixing with saline waters from downdip and underlying hydrostratigraphic units (Sharp and Clement, 1988; Oetting and others, 1996; Groschen and Buszka, 1997; Musgrove and Banner, 2004). Geochemical tracers of mineralsolution reactions (such as the molar ratios of magnesium to calcium $[\mathrm{Mg} / \mathrm{Ca}]$ concentrations and strontium to calcium [Sr/Ca] concentrations) can be indicative of groundwater residence time, which is a function of both flow path and water flux (Musgrove and Banner, 2004; Wong, 2008). Studies in the Barton Springs segment of the aquifer, a smaller segment of this large regional aquifer system (fig. 1), have documented extensive surface water-groundwater interaction, relations between variable hydrologic conditions and water quality in the aquifer, and movement of anthropogenic contaminants and dissolved constituents through the aquifer (Hauwert, Johns, and others, 2004; Hauwert, Sansom, and others, 2004; Mahler and others, 2006; Garner and Mahler, 2007; Mahler and Massei, 2007; Mahler and Garner, 2009). Groundwater resources susceptible to contamination can be affected by a variety of anthropogenic contaminants, including pesticides, volatile organic compounds (VOCs), and nutrients. Analyses of water samples for anthropogenic contaminants in the San Antonio segment of the Edwards aquifer in recent years have detected numerous anthropogenic contaminants, mostly at low concentrations (less than 1 microgram per liter $[\mu \mathrm{g} / \mathrm{L}]$ ) (Bush and others, 2000; Fahlquist and Ardis, 2004).

\section{Hydrogeologic Setting}

The central Texas Edwards aquifer developed in Early Cretaceous-age limestone and dolomite rocks that are extensively faulted, fractured, and karstified. The Edwards aquifer, like many karst aquifers, is characterized by hydrologic variability — water-level altitudes in the aquifer can rise rapidly in response to rainfall and corresponding recharge, accompanied by increases in springflow; conversely, water-level altitudes and springflow decrease during periods of low rainfall and recharge. The San Antonio segment of the Edwards aquifer is present in a narrow band along the Balcones fault zone from the groundwater divide near Las Moras Springs in Kinney County to the groundwater divide north of San Marcos Springs in Hays County (fig. 1). Late Cenozoic faulting of the predominantly flat-lying region along the Balcones fault zone formed a series of high-angle normal en echelon 

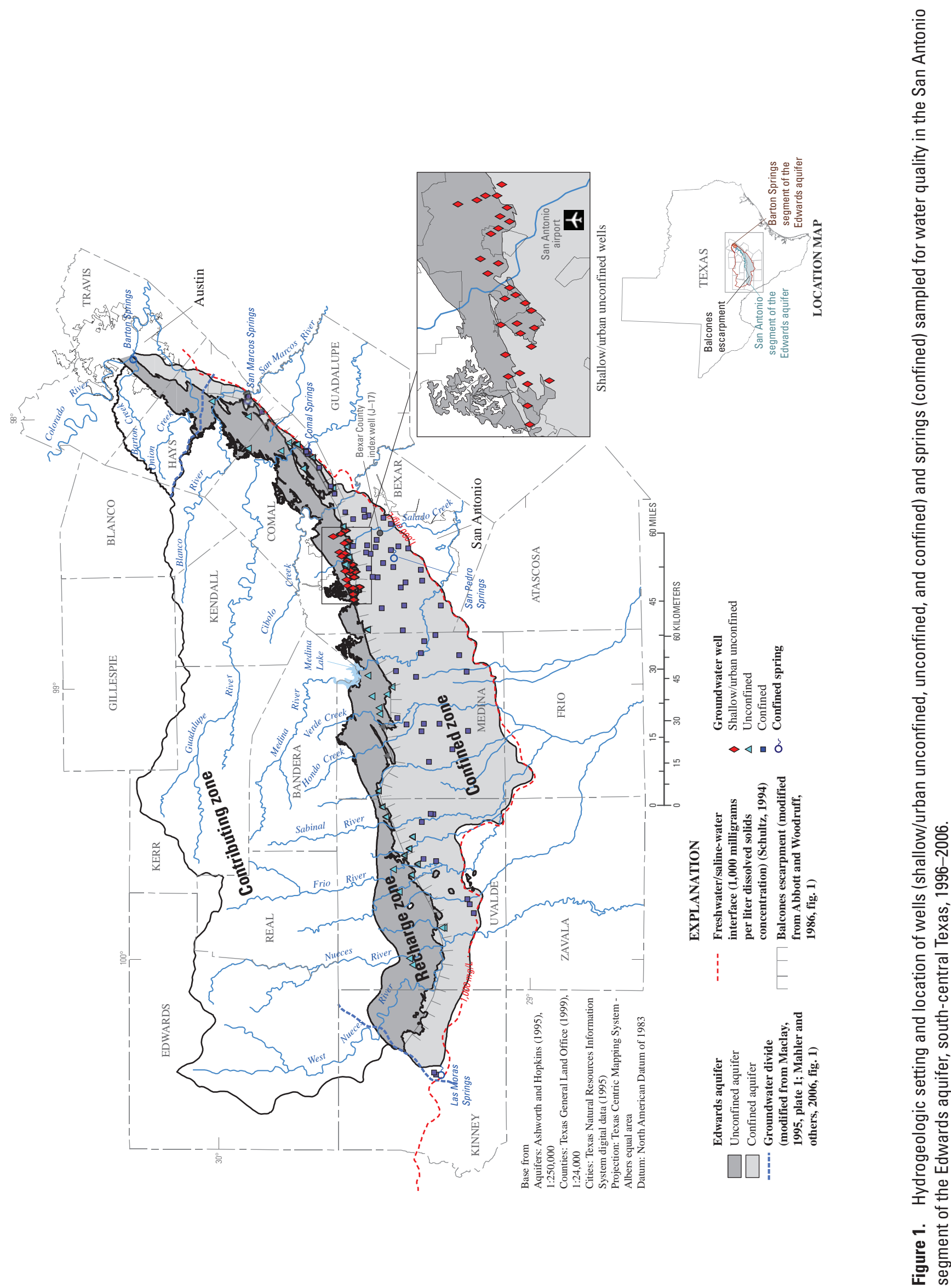
down-toward-the-coast faults. The Balcones escarpment is the surface manifestation of the Balcones fault zone (fig. 1). The faulting resulted in a series of blocks of Edwards aquifer rocks that are partially to completely offset and divide the confined and unconfined parts of the aquifer (Maclay and Small, 1983) (fig. 2). The aquifer is composed of carbonate rocks of the Georgetown Formation (not shown in fig. 2) and Edwards Group (or their stratigraphic equivalents), which range in thickness from 350 to 500 feet (ft) (Burchett and others, 1986). The Georgetown Formation overlies the Edwards Group and is part of the Edwards aquifer. The less permeable upper member of the Glen Rose Limestone (not shown in fig. 2), which is the uppermost part of the Trinity Group, underlies the aquifer and acts as a lower confining unit across much of the region. Where confined, the aquifer is overlain by the Del Rio Clay and other less permeable units. The aquifer is about 180 miles (mi) long from west to east, ranges from 5 to 40 mi wide from north to south (Maclay, 1995), and is characterized by relatively high transmissivities (summarized by Lindgren, 2006). The northern limit of the recharge zone (outcrop) defines the northern aquifer boundary. The aquifer is bounded to the south by the downdip limit of potable water in the aquifer, below which groundwater salinity rises rapidly downgradient (Abbott, 1975; Sharp and Banner, 1997). The freshwater/ saline-water interface (Schultz, 1994) represents the transition (1,000 milligrams per liter [mg/L] dissolved solids concentration) from a zone of more active flow with fresh groundwater to a downdip zone of less active flow with saline groundwater. The downdip saline zone is characterized by numerous complex saline hydrochemical facies (Clement, 1989; Oetting and others, 1996). A small number of volcanic and intrusive igneous rocks locally cross-cut the aquifer, possibly affecting groundwater geochemistry on a local scale.

The recharge zone consists of approximately 1,250 square miles $\left(\mathrm{mi}^{2}\right)$ of Edwards Group limestone exposed at the surface (Hamilton and others, 2008) (fig. 1). Streams flowing south and east toward the Gulf of Mexico drain the Edwards Plateau contributing zone and recharge the aquifer by streamflow losses across the Balcones fault zone, where the porous and permeable Edwards Group outcrops (figs. 1 and 2). Most stream base flow and much of the stormflow recharges the aquifer through open solution channels (Maclay and Land, 1988). The majority of recharge to the Edwards aquifer occurs as losing streams flow across the recharge zone, with estimates of recharge from streams ranging from 60 to 80 percent (Klemt and others, 1979; Maclay and Land, 1988; Thorkildsen and McElhaney, 1992; Ockerman, 2005). Most of the remaining recharge occurs as direct infiltration on the recharge zone, with some recharge occurring by leakage from the underlying Trinity aquifer (Sharp and Banner, 1997). This leakage is not well quantified, but might constitute as much as 10 percent of aquifer recharge (Geary Schindel, Edwards Aquifer Authority, written commun., 2009).

Regional groundwater flow is to the east and northeast with natural discharge occurring at large springs, predominantly Comal and San Marcos Springs (fig. 1). Domestic, livestock, municipal, agricultural, and industrial withdrawals, by way of wells, also contribute to groundwater discharge throughout the region (Hamilton and others, 2008). Recharge and discharge are not evenly distributed across the aquifer; most recharge occurs in the westernmost catchments of the region, whereas most discharge occurs in the eastern area. The proportion of discharge by wells relative to springs varies from year to year; springflow typically exceeds well discharge in wet years, and well discharge typically exceeds springflow in dry years (Hamilton and others, 2008). Comal Springs (fig. 1), one of the major aquifer discharge points, is hydrologically isolated from large sources of local recharge (Ogden and others, 1986). As such, Comal Springs represents the integration of the regional flow system of the San Antonio segment of the aquifer and its flow rate and geochemistry provide an indicator of regional hydrologic conditions. Several wells in the aquifer, such as the Bexar County index well (J-17), intersect major flow paths and respond quickly to changes in recharge and pumping; water-level altitude variations in well $\mathrm{J}-17$ are also indicative of regional hydrologic conditions.

Previous studies indicate that groundwater flow is focused in highly permeable units and is affected by faulting throughout the aquifer (Abbott, 1975; Woodruff and Abbott, 1979; Maclay and Small, 1986; Maclay and Land, 1988; Sharp, 1990). Water-level altitudes in the aquifer can rise rapidly in response to rainfall and corresponding recharge, accompanied by increases in springflow (high aquifer flow conditions); conversely, water-level altitudes and springflow decrease during periods of low rainfall and recharge (low aquifer flow conditions). Records of San Antonio rainfall (recorded at the San Antonio International Airport [National Oceanic and Atmospheric Administration, 2009]), discharge at Comal Springs, and water-level altitudes at well J-17 (Edwards Aquifer Authority, 2009) illustrate the hydrologic variability of the Edwards aquifer (fig. 3).

Mean annual rainfall decreases across the region from east to west, equaling 30.3 inches (in.) per year in San Antonio. The region is prone to climatic and hydrologic extremes (Griffiths and Straus, 1985; Jones, 1991). Some of the most extreme 1-day duration storms in the world have occurred along the Balcones escarpment (Slade, 1986). During the study period (1996-2006) annual rainfall in San Antonio ranged from $16.6 \mathrm{in.} \mathrm{(1999)} \mathrm{to} 46.3 \mathrm{in.} \mathrm{(2002).} \mathrm{Storms} \mathrm{often}$ produce rapid runoff that provides recharge to the aquifer; numerous storms occurred during the 10-year study period. Droughts lasting from many months to years have been documented in the region since the earliest settlers began keeping records (Texas State Historical Association, 2009). During the study period, droughts lasting several months occurred in 1996, 1998, 2000, and 2006. Wet periods occurred in summer and fall 1997, fall and winter 1998, late 2000 and early 2001, late 2001 and early 2002, and through most of 2003-05. These dry and wet periods were accompanied by changes in spring discharge (fig. 3) and water-level altitudes in wells. Comal Springs discharge during the study period ranged from 83 to 509 cubic feet per second $\left(\mathrm{ft}^{3} / \mathrm{s}\right)$, with a median value of 335 


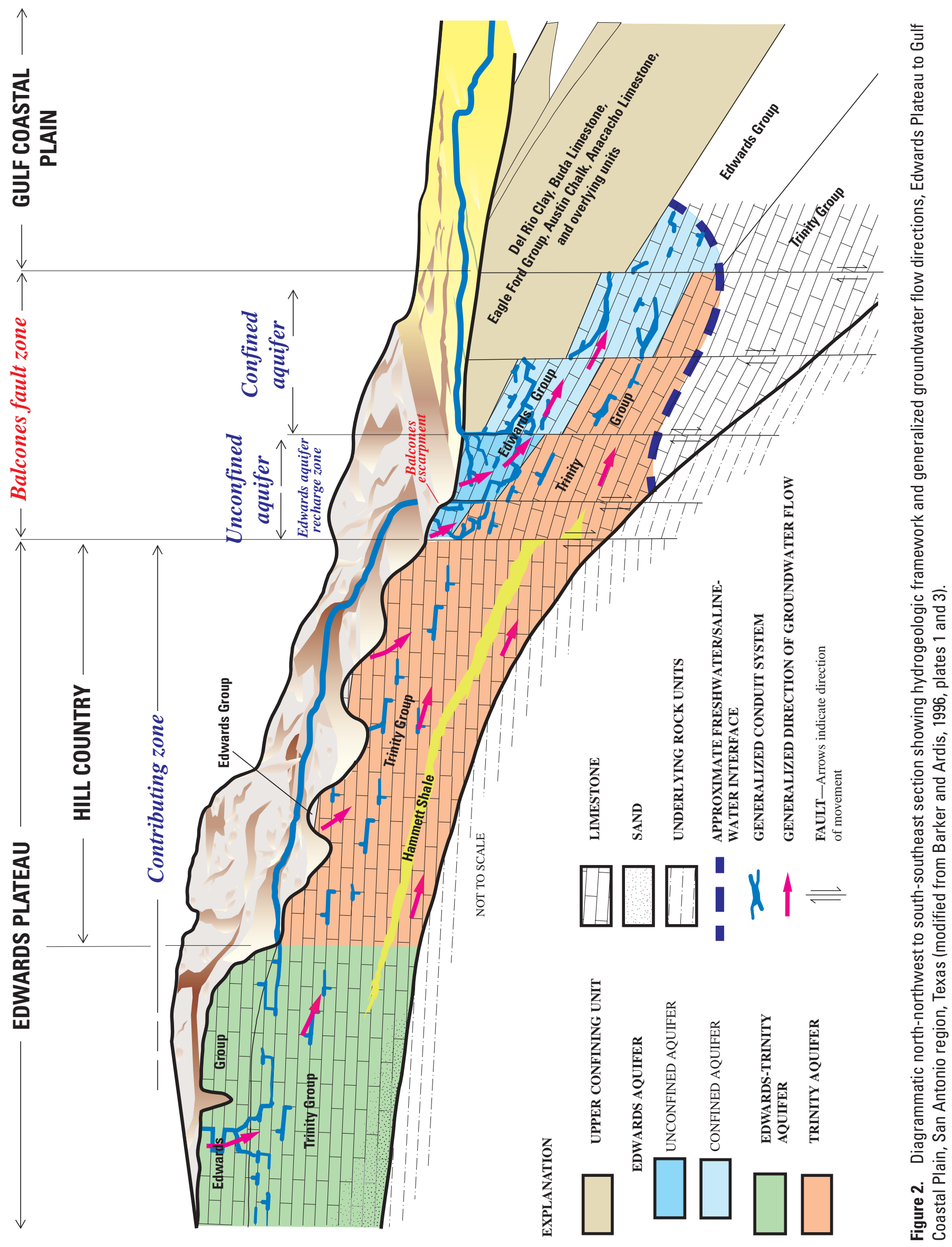




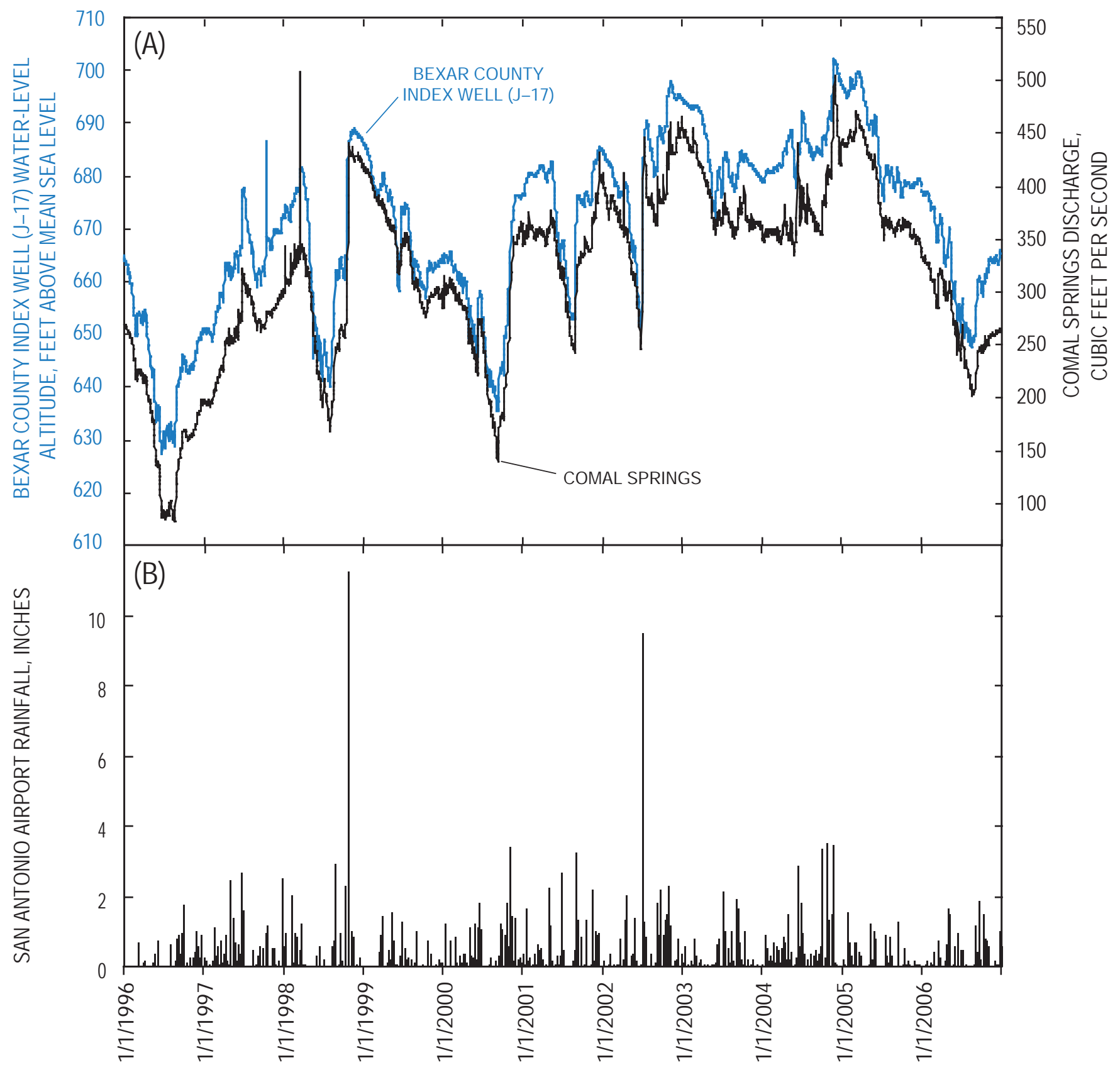

Figure 3. Time series (1996-2006) of (A) Comal Springs discharge and Bexar County index well (J-17) water-level altitude (Edwards Aquifer Authority, 2009), and (B) San Antonio rainfall (recorded at the San Antonio International Airport) (National Oceanic and Atmospheric Administration, 2009).

$\mathrm{ft}^{3} / \mathrm{s}$, which is close to the historical median (1930-2007) of $308 \mathrm{ft}^{3} / \mathrm{s}$.

Most of the land use in the region correlates with physiography (fig. 4). The Edwards Plateau is characterized by thin soils and is predominantly undeveloped rangeland. There is little agriculture in the study area, with agricultural lands mostly on the coastal plain to the west of San Antonio, over the confined aquifer. Regional land use is characterized as 3 percent agriculture, 6 percent urban, and 90 percent forest and rangeland (including shrub and grassland); the remaining 1 percent is water, wetlands, and barren land (Homer and others, 2001) (fig. 4). The city of San Antonio is the principal urban area and includes much of Bexar County in the east-central part of the aquifer region. San Antonio is the seventh largest city in the United States with a 2007 population of about 1.3 million (U.S. Census Bureau, 2009). Although pumping in the San Antonio area has increased about fivefold since the 1930s, aquifer water-level altitudes have not shown long-term declines because the aquifer readily recharges during periods of rainfall (Bush and others, 2000). 


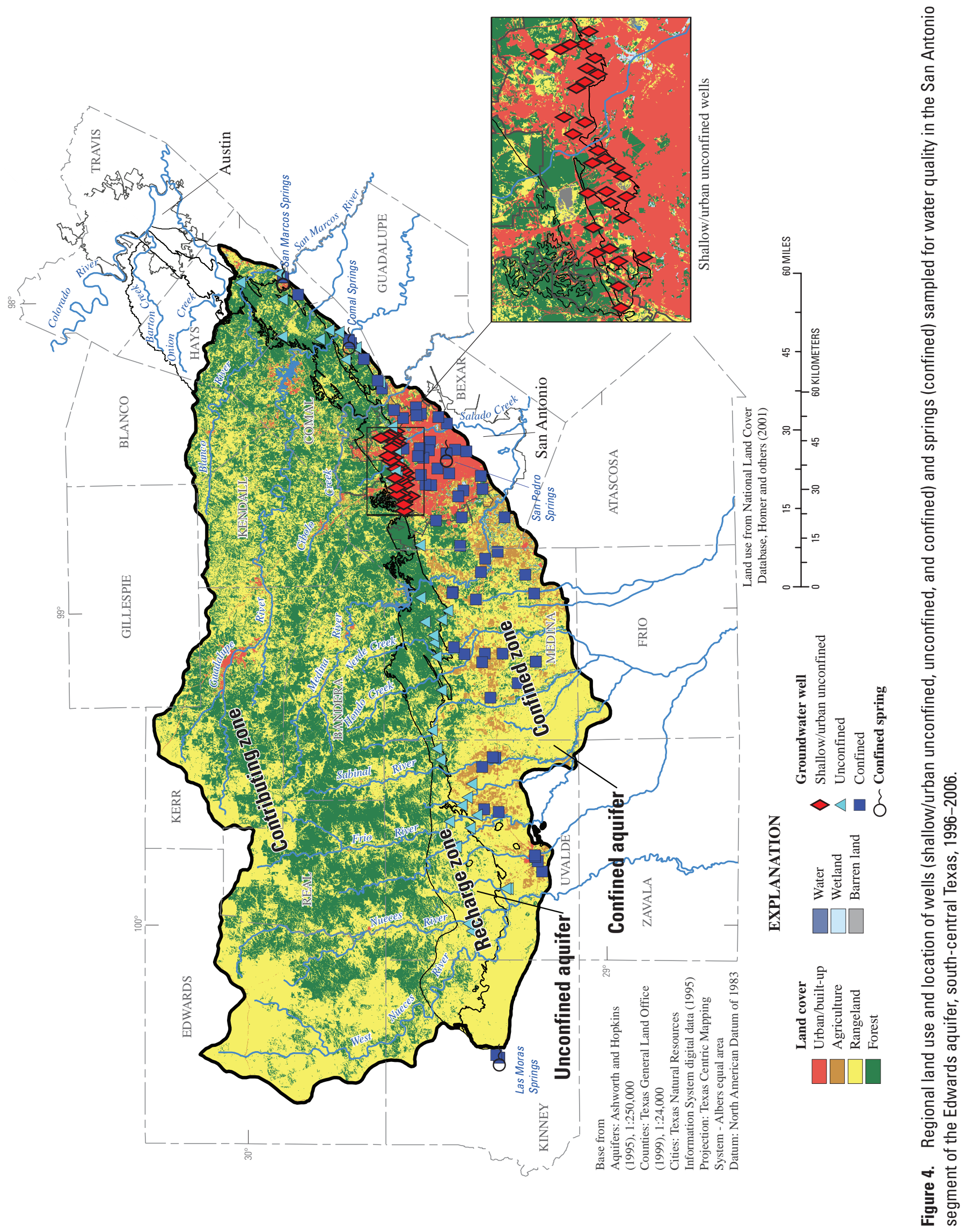


Water-quality concerns associated with land use include contaminants resulting from development and urbanization on the recharge zone (anthropogenic contaminants), abandoned or poorly completed water wells, and urban nonpoint runoff (Hamilton and others, 2008). Like many karst aquifers, high porosity and permeability and rapid flow of recharging surface water through conduits, with little to no filtration, render the Edwards aquifer highly susceptible to contamination.

\section{Variability in Water Quality in Karst Aquifers}

Karst aquifers are characterized by extreme variability and rapid response to changes in environmental, climatic, and hydrologic conditions, which exert a fundamental control on groundwater geochemistry and water quality. Temporal variability in hydrologic conditions for the Edwards aquifer is apparent in data for rainfall, aquifer recharge, water-level altitudes in wells, and springflow (for example, fig. 3). Temporal changes in hydrologic conditions such as waterlevel altitudes, recharge, groundwater travel times, and flow routing affect hydrogeologic processes, including the extent of variability in water-rock interaction processes, dilution of recharge, and associated geochemistry. Rapidly changing hydrologic conditions and a continuum of flow pathways from matrix to conduit flow imply that hydrogeologic processes might operate on different temporal and spatial scales in different parts of the aquifer. For example, groundwater dominated by matrix/diffuse flow or less affected by focused recharge might exhibit less temporal variability than groundwater affected by focused recharge and conduit flow. Numerous studies have documented temporal variability in karst groundwater in response to changes in hydrologic conditions, storms, and recharge, and variable mixtures of base flow and stormflow (for example, Hess and White, 1993; Desmarais and Rojstaczer, 2002; Vesper and White, 2004; Winston and Criss, 2004).

Previous work in the Edwards aquifer has used temporal variability in geochemistry to investigate transport and the influence of hydrologic conditions. Mahler and Massei (2007) describe rapid changes in concentrations of anthropogenic contaminants in springflow in response to storms in the Barton Springs segment of the Edwards aquifer. Musgrove and Banner (2004) describe temporal variations in unsaturated-zone groundwater geochemistry that record changes in hydrologic conditions. Mahler (2008) investigates the relation between rainfall and aquifer water level on groundwater geochemistry for a group of wells transecting the freshwater/ saline-water interface in San Antonio, showing a clear relation for some wells and constituents.

\section{Methods}

The USGS collected groundwater samples from Edwards aquifer groundwater wells and springs during 1996-2006 for studies done as part of the NAWQA Program (table 1; appendix 1). Sampling primarily occurred during 1996-98 and again during 2005-06. A small subset of wells was sampled repeatedly during 1999-2004. The resulting groundwater dataset encompasses a total of 249 samples collected from 136 sites between June 1996 and December 2006. For this analysis, groundwater samples are grouped into categories of "shallow/urban unconfined," "unconfined," and "confined." These categories are representative of groundwater evolution along a hypothetical flow path encompassing endmembers of (1) shallow, unconfined, younger, less geochemically evolved groundwater (shallow/urban unconfined category) and (2) deep, confined, older, more geochemically evolved groundwater (confined category). Unconfined groundwater is intermediate between these two endmembers in this conceptual flow path. Monitoring wells from which samples in the shallow/urban unconfined category were collected are relatively shallow (median well depth of $263 \mathrm{ft}$ below land surface). Wells from which samples in the unconfined and confined categories were collected, in comparison, have median well depths of 385 and $859 \mathrm{ft}$ below land surface, respectively (excluding those with unknown well depths). Groundwater samples collected from four springs discharging from the confined part of the Edwards aquifer (Las Moras, San Pedro, Comal, and San Marcos Springs) are included in the confined category.

NAWQA studies of the San Antonio segment of the Edwards aquifer during 1996-2006 provide groundwater geochemistry data with extensive spatial coverage of the Edwards aquifer. Time-series data, for the most part, were limited to one or two samples over the 10-year study period. A small number of the shallow/urban unconfined groundwater sampling sites had a higher frequency of sampling and these results provide a more extensive time series of geochemical variability. Samples were collected eight times over the 10-year study period from five shallow/urban unconfined sampling sites in Bexar County (appendix 1). Time-series water-level and water-quality data for these five wells allow for analysis of controls on water-quality variations (environmental, climatic, and hydrologic conditions), sources of anthropogenic contaminants, and the relation between hydrologic conditions and water quality. High-resolution time-series data for regional hydrologic conditions, including rainfall, discharge at Comal Springs, and water-level altitudes in the confined Bexar County index well (J-17) are readily available for comparison (Edwards Aquifer Authority, 2009; National Oceanic and Atmospheric Administration, 2009).

Different groups of wells and springs were sampled. The first group consisted of 30 water-level monitoring wells completed in 1998 in the urban San Antonio recharge zone (outcrop) of the Edwards aquifer in northern Bexar County; the recharge zone is the unconfined part of the aquifer. All of these wells are relatively shallow (median well depth of $263 \mathrm{ft}$ below land surface); their locations were chosen randomly as part of a statistical sampling design throughout the urban areal extent of the aquifer. The land-use setting of each of these wells is classified as either residential or commercial; about 
Table 1. Summary of constituents by group for groundwater samples collected for National Water-Quality Assessment studies, San Antonio segment of the Edwards aquifer, south-central Texas, 1996-2006.

$\left[{ }^{87} \mathrm{Sr} /{ }^{86} \mathrm{Sr}\right.$, strontium-87/strontium-86; $\delta \mathrm{D}$, delta deuterium; $\delta^{18} \mathrm{O}$, delta oxygen-18; $\delta^{13} \mathrm{C}$, delta carbon-13]

\begin{tabular}{|c|c|c|c|c|c|c|c|c|c|c|c|c|c|c|c|c|}
\hline Well type & $\begin{array}{l}\text { Year } \\
\text { sam- } \\
\text { pled }\end{array}$ & $\begin{array}{l}\text { Num- } \\
\text { ber of } \\
\text { wells } \\
\text { sam- } \\
\text { pled }\end{array}$ & $\begin{array}{l}\text { Physico- } \\
\text { chem- } \\
\text { ical } \\
\text { constit- } \\
\text { uents }\end{array}$ & $\begin{array}{c}\text { Major } \\
\text { ions }\end{array}$ & $\begin{array}{c}\text { Trace } \\
\text { ele- } \\
\text { ments }\end{array}$ & $\begin{array}{c}\text { Nutri- } \\
\text { ents }\end{array}$ & $\begin{array}{c}\text { Dis- } \\
\text { solved } \\
\text { or- } \\
\text { ganic } \\
\text { carbon }\end{array}$ & $\begin{array}{c}\text { Volatile } \\
\text { organic } \\
\text { com- } \\
\text { pounds }\end{array}$ & $\begin{array}{c}\text { Pesti- } \\
\text { cide } \\
\text { com- } \\
\text { pounds }\end{array}$ & $\begin{array}{c}\text { Waste- } \\
\text { water } \\
\text { indicator } \\
\text { com- } \\
\text { pounds }\end{array}$ & $\begin{array}{c}\text { Age } \\
\text { trac- } \\
\text { ers }^{1}\end{array}$ & $\begin{array}{l}{ }^{87} \mathrm{Sr} / \\
{ }^{86} \mathrm{Sr}\end{array}$ & $\begin{array}{c}\delta \mathbf{D} \\
\delta^{18} \mathbf{O}\end{array}$ & $\delta^{13} \mathrm{C}$ & Radon & $\begin{array}{l}\text { Ra- } \\
\text { dium }\end{array}$ \\
\hline \multicolumn{17}{|c|}{ Shallow/urban unconfined } \\
\hline Monitor & 1998 & 30 & $\mathrm{x}$ & $\mathrm{x}$ & $\mathrm{x}$ & $\mathrm{x}$ & $\mathrm{x}$ & $\mathrm{x}$ & $\mathrm{x}$ & & $\mathrm{x}$ & $\mathrm{x}$ & $\mathrm{x}$ & $\mathrm{x}$ & & \\
\hline \multicolumn{17}{|c|}{ Unconfined } \\
\hline Domestic & $\begin{array}{l}2002 \\
2005\end{array}$ & 5 & $\mathrm{x}$ & $\mathrm{x}$ & $\mathrm{x}$ & $\mathrm{x}$ & & $\mathrm{x}$ & $\mathrm{x}$ & & & & & & & \\
\hline Public & 2005 & 3 & $\mathrm{x}$ & $\mathrm{x}$ & $\mathrm{x}$ & $\mathrm{x}$ & $\mathrm{x}$ & $\mathrm{x}$ & $\mathrm{x}$ & $\mathrm{x}$ & & & & & & \\
\hline \multicolumn{17}{|c|}{ Confined } \\
\hline $\begin{array}{l}\text { Mostly } \\
\text { public }{ }^{2}\end{array}$ & 1997 & 36 & $\mathrm{x}$ & $\mathrm{x}$ & $\mathrm{x}$ & $\mathrm{x}$ & $\mathrm{x}$ & $\mathrm{x}$ & $\mathrm{x}$ & & $\mathrm{x}$ & & $\mathrm{x}$ & & $\mathrm{x}$ & \\
\hline Public & 2005 & 8 & $\mathrm{x}$ & & & & & $\mathrm{x}$ & $\mathrm{x}$ & $\mathrm{x}$ & & & & & & \\
\hline Public & $\begin{array}{l}2004 \\
2005\end{array}$ & 34 & $\mathrm{x}$ & $\mathrm{x}$ & $\mathrm{x}$ & $\mathrm{x}$ & $\mathrm{x}$ & $\mathrm{x}$ & $\mathrm{x}$ & $\mathrm{x}$ & & & & & & \\
\hline
\end{tabular}

${ }^{1}$ More information on age tracers in table 6.

${ }^{2}$ Includes samples from four springs (Las Moras, San Pedro, Comal, and San Marcos).

30 years ago, all of this area was outside the urban footprint of San Antonio on ranch or farmland. These wells and the samples collected from them are categorized hereinafter as the "shallow/urban unconfined" groundwater category. The shallow/urban unconfined wells were sampled in 1998 and again in 2006. Different hydrologic conditions were associated with the two sampling periods. Samples were collected after a large storm in fall 1998, with a correspondingly larger amount of aquifer recharge, higher water-level altitudes, and larger spring discharges compared to 2006, a relatively dry year. Median springflow at Comal Springs during the 1998 sampling period was $429 \mathrm{ft}^{3} / \mathrm{s}$, compared to $247 \mathrm{ft}^{3} / \mathrm{s}$ during the 2006 sampling period for these wells. Additionally, five of the 30 shallow/urban unconfined wells were designated for more frequent sampling to document long-term geochemical trends and were sampled as many as six additional times between 1998 and 2006, under varying hydrologic conditions.

The second group of wells included primarily domesticsupply wells completed in the San Antonio segment of the recharge zone (outcrop area) of the Edwards aquifer in a variety of land-use settings but at greater depths compared to those in the shallow/urban unconfined category. The median depth of wells in the second group was $385 \mathrm{ft}$ below land surface (excluding those with unknown well depths). Wells in the second group and the samples collected from them are categorized hereinafter as the "unconfined" groundwater category. Wells in the unconfined groundwater category, located randomly as part of a statistical sampling design throughout the areal extent of the unconfined aquifer, were sampled in 1996 and 2006. Twenty-eight wells in this category were sampled in 1996 and 23 of these were resampled in 2006, as well as 7 additional wells in this category. Five of the unconfined category wells were also sampled in 2002 and 2005. Different hydrologic conditions prevailed during the two main sampling intervals for unconfined category wells; conditions were exceptionally dry in 1996 (median discharge at Comal Springs was $92 \mathrm{ft}^{3} / \mathrm{s}$ ) and moderately dry in 2006 (median discharge at Comal Springs was $269 \mathrm{ft}^{3} / \mathrm{s}$ ). A few of the unconfined groundwater category wells are located south of the land-surface delineation of the unconfined aquifer (fig. 1). These wells are located near the aquifer unconfined 
(outcrop) area and are classified as unconfined groundwater category wells on the basis of water-level altitude fluctuations similar to those observed in other unconfined (subcrop) wells.

The third group of sampling locations consisted of mostly public-supply wells completed in the confined part of the Edwards aquifer and springs discharging from the confined part of the aquifer. These wells and springs and the samples collected from them are categorized hereinafter as the "confined" groundwater category. Wells from which samples in the confined category were collected have median well depths of $859 \mathrm{ft}$ below land surface (excluding those with unknown well depths). Thirty-six samples were collected in 1997 from wells and springs in the confined groundwater category. Sampling sites were mostly wells; six samples were collected from four springs discharging from the confined part of the aquifer (Las Moras, San Pedro [two orifices], Comal, and San Marcos [two orifices] Springs). Hydrologic conditions during the 1997 sampling period, as represented by discharge at Comal Springs, were close to the historical median value of $308 \mathrm{ft}^{3} / \mathrm{s}$ (median discharge during the sampling period was $296 \mathrm{ft}^{3} / \mathrm{s}$ ).

Thirty-nine randomly selected public-supply wells throughout the aquifer were sampled during 2004-05 as part of NAWQA source-water quality assessment and transport of anthropogenic and natural contaminants (TANC) to publicsupply wells studies. Of these 39 wells, 34 were completed in the confined part of the aquifer and 5 were completed in the unconfined part of the aquifer. Samples collected from these wells are included in the confined and unconfined categories, respectively. Fifteen of these public-supply wells were large-capacity wells selected from the top quartile of pumping (76th to 100th percentile), 13 of which are in Bexar County. The remaining 24 public-supply wells that were sampled included 8 each from the lower 3 quartiles of pumping. A few of these confined category wells were also sampled in 1997. Hydrologic conditions during the 2004-05 sampling period were relatively wet (median Comal Springs discharge of $\left.399 \mathrm{ft}^{3} / \mathrm{s}\right)$.

The aquifer sample categories of shallow/urban unconfined, unconfined, and confined groundwater are useful for contrasting different regional hydrologic and land-use effects on water quality. The hypothesis that land use affects water quality is well established and has been explored in a variety of settings (Eckhardt and Stackelberg, 1995; Honisch and others, 2002). The water-quality data associated with the categories of shallow/urban unconfined, unconfined, and confined groundwater represent different types of land use that can help explain differences in water quality. Wells in the shallow/urban unconfined category are in northern Bexar County, a rapidly urbanizing area. Groundwater samples from these wells provide information about urban influences on water quality in contrast to other hydrologic settings. Wells in the unconfined category, while randomly located throughout the unconfined part of the aquifer, were mostly in undeveloped and rangeland land-use settings. Wells and springs in the confined category, randomly located throughout the confined part of the aquifer, are in both developed and undeveloped land-use settings.
Physicochemical properties (depth to water, air and water temperature, air pressure, dissolved oxygen, specific conductance, $\mathrm{pH}$, turbidity, and alkalinity) were measured in the field at the time of sample collection. Samples were analyzed at USGS laboratories (with a few noted exceptions) for numerous geochemical constituents, including major ions; nutrients; trace elements; isotopes (hydrogen [hydrogen-2/hydrogen-1 $\left({ }^{2} \mathrm{H} /{ }^{1} \mathrm{H}\right)$ ], oxygen [oxygen-18/oxygen-16 $\left({ }^{18} \mathrm{O} /{ }^{16} \mathrm{O}\right)$ ], carbon [carbon-13/carbon-12 $\left({ }^{13} \mathrm{C} /{ }^{12} \mathrm{C}\right)$ ], and strontium [strontium-87/ strontium-86 $\left.\left.\left({ }^{87} \mathrm{Sr} /{ }^{86} \mathrm{Sr}\right)\right]\right)$; tritium $\left({ }^{3} \mathrm{H}\right)$ and other geochemical age tracers; radon $(\mathrm{Rn})$; radium $(\mathrm{Ra})$; dissolved organic carbon; pesticide compounds; and volatile organic compounds (VOCs) (table 1). Results for hydrogen and oxygen isotopes in water are reported as delta deuterium $(\delta \mathrm{D})$ and delta oxygen-18 $\left(\delta^{18} \mathrm{O}\right)$, respectively, which represent the relative difference in parts per thousand (per mil) between the sample isotope ratio and the isotope ratio of a known standard (Vienna Standard Mean Ocean Water [VSMOW]) (Hagemann and others, 1970; Baertschi, 1976). Not all constituents were measured on all samples; some samples were analyzed for fewer constituents depending on specific study objectives. Some analyses for ${ }^{87} \mathrm{Sr} /{ }^{86} \mathrm{Sr}$ were done at the University of Texas at Austin (Musgrove, 2000).

Site selection for pre-existing and newly drilled wells followed protocols described by Gilliom and others (1995), Lapham and others (1995), and Squillace and Price (1996). All samples were collected according to protocols developed for the NAWQA Program (Koterba and others, 1995; Lapham and others, 1995; Koterba, 1998; U.S. Geological Survey, variously dated). In addition to laboratory quality-control samples, field quality-control samples were collected in the form of replicate, organic spike, and blank samples to aid in evaluating data quality. All of the analytical data, including results for quality-control samples, are in the USGS National Water Information System (NWIS) (U.S. Geological Survey, 2009). A list of references describing analytical methods is provided in Fahlquist (2003). Results for groundwater samples collected from the Edwards aquifer during 1996-98 as part of the NAWQA Program are discussed by Bush and others (2000) and Fahlquist and Ardis (2004). USGS analytical method reporting conventions are defined in Childress and others (1999) and include laboratory reporting level, minimum reporting level, method detection limit, and long-term method detection level. The types of reporting levels for data considered herein varied depending on constituent, analytical methods, and time period. In this report, laboratory reporting level is used inclusively to describe reporting levels.

Also considered in the analyses for this report are data for groundwater quality, water level, and spring discharge from the Edwards Aquifer Authority (2009) and San Antonio Water System (Hydrogeologic Studies and Assessment Division, written commun., 2009). Comal Springs discharge and Bexar County index well (J-17) water-level altitudes, as well as data included in annual "Hydrogeologic Data Reports," are available online from the Edwards Aquifer Authority (2009). Some water-level altitude, spring discharge, and surface-water and 
groundwater-quality data (1960-2006) from other studies and (or) sites were acquired from the USGS NWIS database (U.S. Geological Survey, 2009). Available historical geochemical data largely consist of inorganic data, for example major ions, trace elements, and (or) nutrients. Although few multidecadal historical data are available, a small number of groundwater wells distributed across the aquifer have geochemical data extending back to the 1970s. Rainfall data measured at the San Antonio International Airport during 1996-2006 (Coop ID 417945) (fig. 3) were acquired from the National Climatic Data Center (National Oceanic and Atmospheric Administration, 2009).

NAWQA surface-water studies have included sampling of some of the streams that directly recharge the Edwards aquifer; many of these sites have been sampled multiple times by the USGS and the data are available in the USGS NWIS database (U.S. Geological Survey, 2009). Geochemical data for 24 surface-water sites across the San Antonio segment of the aquifer and within or in close proximity to the recharge zone were compiled for comparison with groundwater data to assess potential surface-water contributions to groundwater (fig. 5; table 2). Data collected for these sites during 1996-2007, the same approximate sampling period as NAWQA groundwater studies, were considered. These surface-water sites are in a variety of land-use settings.

Nonparametric statistical tests were used to interpret the data. A non-normal distribution is a common characteristic of water-resources data (Helsel and Hirsch, 2002); as a result, non-parametric methods are usually better suited to evaluate water-resources data than traditional parametric methods, which require a normal distribution. The Kendall's tau coefficient is a non-parametric, rank-based test used to measure the strength of the monotonic relation between $\mathrm{x}$ and $\mathrm{y}$ (linear and nonlinear) and is resistant to the effects of outliers (Helsel and Hirsch, 2002). The tau coefficient ranges from -1 to 1; a value of 0 indicates no correlation, values approaching -1 or 1 indicate an increasing strength of correlation. The tau coefficient values generally will be lower than values of traditional correlation coefficients for linear associations of the same strength; for example, a strong linear correlation of greater than or equal to .9 corresponds to a tau value of greater than or equal to about 7 (Helsel and Hirsch, 2002). The Kendall's tau coefficient also was used as a tool to evaluate temporal trends, with one ranking representing time. The variety of data collected by the NAWQA Program, represented by different sample categories that were collected during specific time intervals, does not result in the type of time-series dataset appropriate for trend testing. Instead, the Mann-Whitney U test, a nonparametric test for comparing two independent groups of data, was used to test for differences between the three sample categories (samples collected from the shallow/urban unconfined, unconfined, and confined parts of the Edwards aquifer) and groups of samples collected over different time intervals (for example, unconfined category wells sampled in 1996 and in 2006). For this report, statistical results with p-values less than .05 are considered statistically significant and are reported.
The geochemical modeling program PHREEQC (Parkhurst, 1995) was used to calculate ion speciation and mineral saturation states.

\section{Overview of Geochemical Data}

Using previously published NAWQA data (U.S. Geological Survey, 2009), summary statistics (minimum, maximum, median, 25th and 75th percentiles) were calculated for all Edwards aquifer groundwater samples and for the shallow/ urban unconfined, unconfined, and confined sample categories (table 3 [at end of report], physicochemical, field properties, inorganic, and isotopic properties and constituents; and table 4 [at end of report], organic constituents). Site information for wells and springs sampled by the NAWQA Program during 1996-2006 is provided in appendix 1 . All of the data used in this report are listed in appendixes 2-11.

Edwards aquifer groundwater exhibits a relatively narrow range in major ion compositions across the region and is mostly a dilute calcium-bicarbonate facies; the term "facies" refers to a classification scheme used to describe the water in terms of the major anions and cations that the aquifer contains (Renken, 1998) (fig. 6). Specific conductance, which reflects the total dissolved solids content of the water, ranges from 377 to 1,200 microsiemens per centimeter at 25 degrees Celsius $(\mu \mathrm{S} / \mathrm{cm})$ with a median value of $551 \mu \mathrm{S} /$ $\mathrm{cm}$. A small number of groundwater samples had relatively high specific conductance values associated with relatively high concentrations of selected major ions, including chloride $(\mathrm{Cl})$, sulfate $\left(\mathrm{SO}_{4}\right)$, sodium $(\mathrm{Na})$, and (or) magnesium $(\mathrm{Mg})$. Samples of shallow/urban unconfined groundwater have (1) higher median values for specific conductance, dissolved oxygen, calcium $(\mathrm{Ca})$, and alkalinity concentrations and higher strontium isotope ratios; and (2) lower median values for $\mathrm{Mg}$, strontium ( $\mathrm{Sr}$ ), and fluoride (F) concentrations and $\mathrm{Mg} / \mathrm{Ca}$ and $\mathrm{Sr} / \mathrm{Ca}$ molar ratios, than do unconfined and confined groundwater samples. Median values for potassium $(\mathrm{K})$, bromide (Br), $\mathrm{Na}, \mathrm{Cl}, \mathrm{SO}_{4}$, and many trace metal concentrations (boron, chromium, copper, lithium, lead, and uranium) are lower in shallow/urban unconfined and (or) unconfined groundwater relative to confined groundwater. Median nitrate $\left(\mathrm{NO}_{3}\right)$ concentrations are similar in shallow/urban unconfined and confined groundwater samples ( 1.85 and $1.84 \mathrm{mg} / \mathrm{L}$, respectively), and lower in unconfined groundwater samples $(1.09 \mathrm{mg} / \mathrm{L})$.

Most Edwards aquifer groundwater samples were close to saturation with respect to calcite (median saturation index $[\mathrm{SI}]=-0.12)$, but undersaturated with respect to dolomite (median SI $=-0.83)$ and gypsum (median SI $=-2.36)$ (table $3)$. Confined groundwater samples are generally closer to equilibrium with respect to calcite, dolomite, and to a lesser degree, gypsum and anhydrite, than are unconfined and shallow/urban unconfined groundwater samples. Dolomite mineral SIs, in particular, show a progression toward greater saturation from shallow/urban unconfined to unconfined to confined groundwater samples (median SI $=-0.97,-0.78$, and 


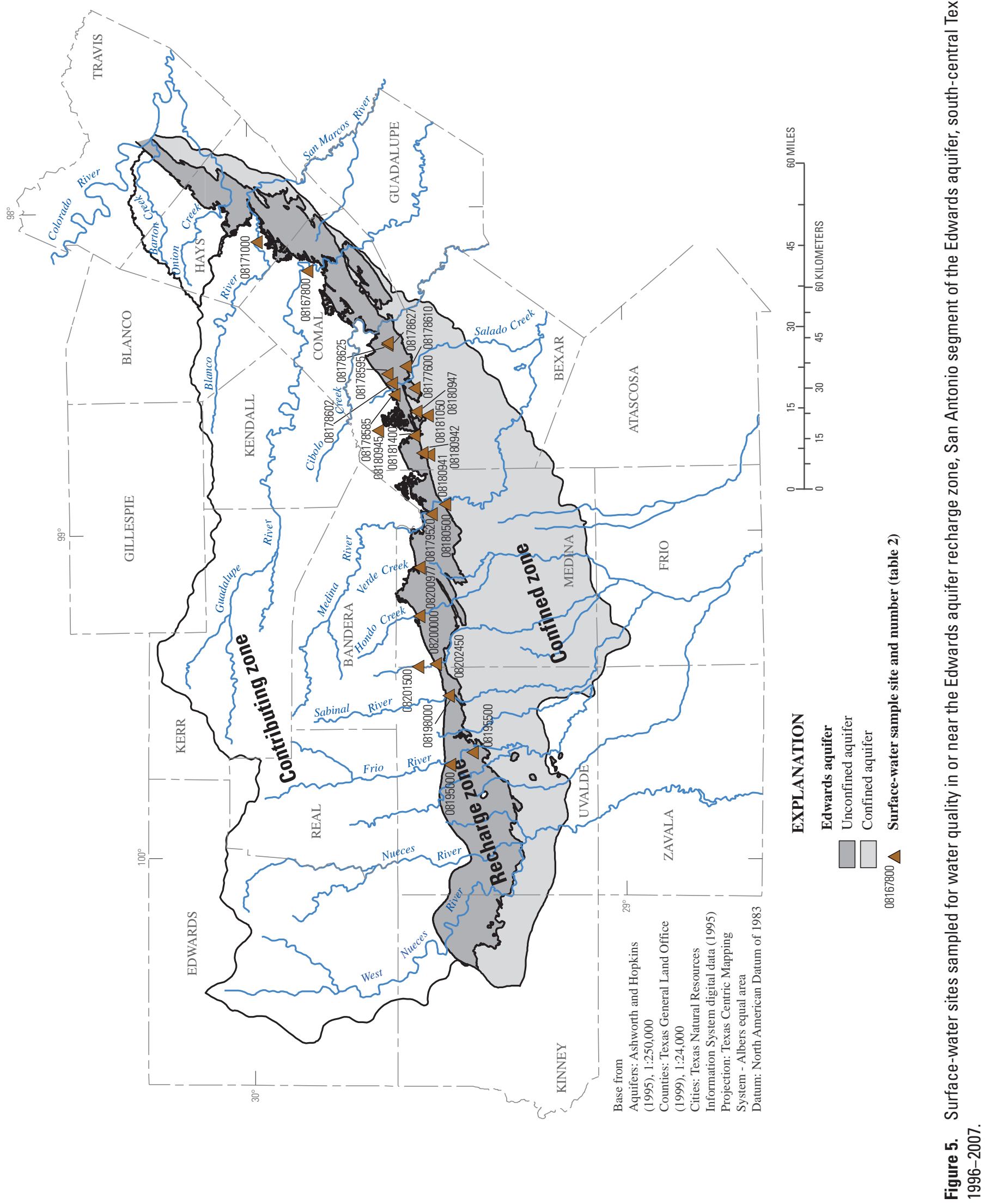




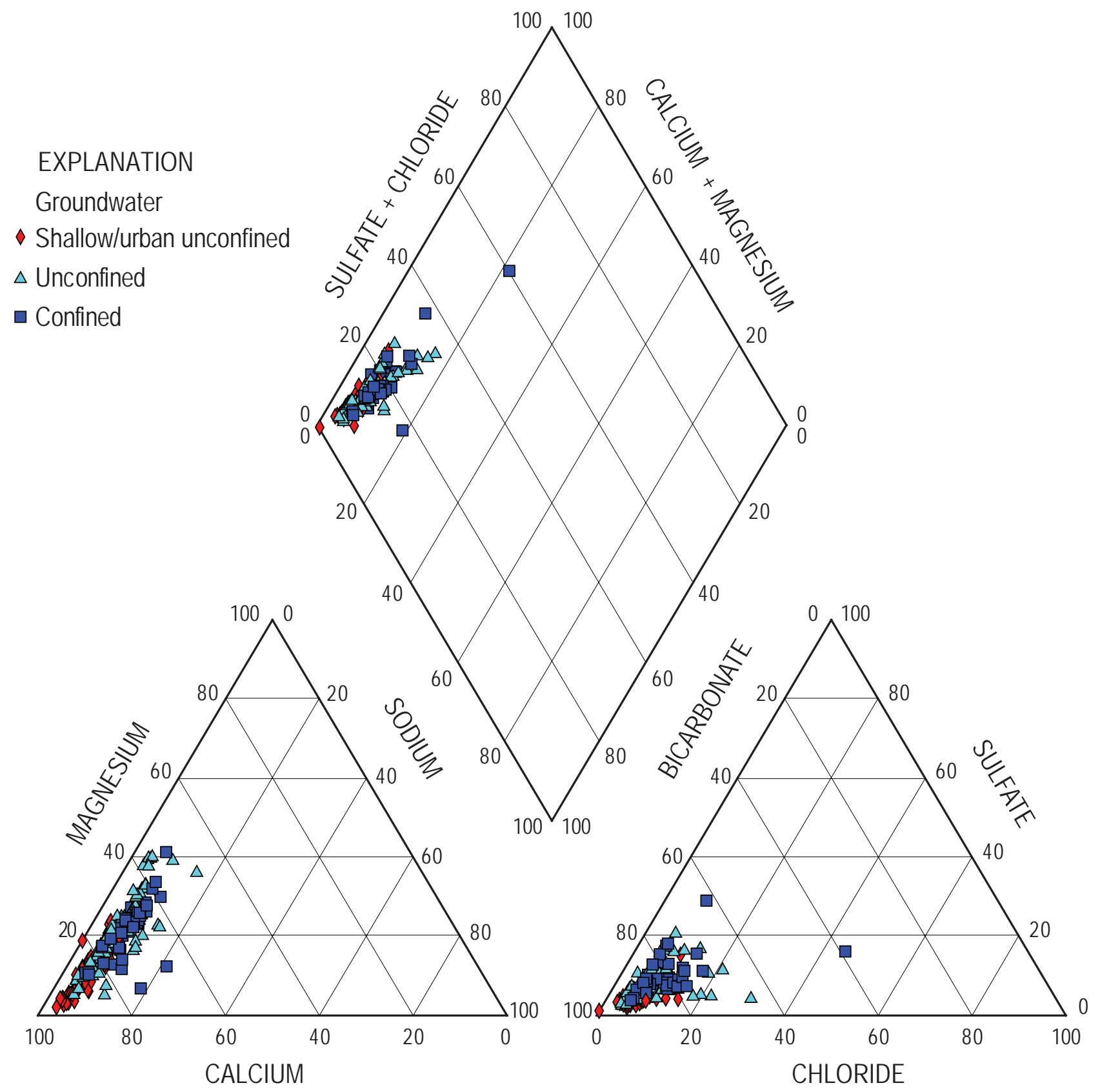

MILLIEQUIVALENTS, PERCENT

Figure 6. Trilinear diagram showing relations between major cations and anions in groundwater collected from shallow/urban unconfined, unconfined, and confined parts of the San Antonio segment of the Edwards aquifer, south-central Texas, 1996-2006.

-0.47 , respectively). Calcite SIs for shallow/urban unconfined groundwater samples collected in 2006 during moderately dry hydrologic conditions are closer to equilibrium (median $\mathrm{SI}=-0.05$ ) and statistically different (on the basis of MannWhitney U test results) than SIs for samples collected in 1998 when conditions were wetter (median SI = -0.16).

NAWQA studies detected a total of 63 anthropogenic organic contaminants in groundwater from the San Antonio segment of the Edwards aquifer (Bush and others, 2000;
Fahlquist and Ardis, 2004). Concentrations of all detected anthropogenic contaminants were routinely low, typically much less than $1 \mu \mathrm{g} / \mathrm{L}$, and less than U.S. Environmental Protection Agency (EPA) public drinking-water standards (specifically, maximum contaminant levels [MCLs]). The majority of anthropogenic contaminants were detected infrequently (that is, detected in less than 5 percent of samples). A small number of anthropogenic contaminants were routinely or frequently detected (that is, detected in 30 percent or more 
Table 2. Surface-water sites sampled for water quality in or near the Edwards aquifer recharge zone, San Antonio segment of the Edwards aquifer, south-central Texas, 1996-2007.

[USGS, U.S. Geological Survey; FM, Farm Road; SH, State Highway]

\begin{tabular}{|c|c|c|c|c|c|c|}
\hline USGS station name & $\begin{array}{c}\text { USGS } \\
\text { identification } \\
\text { number } \\
\text { (fig. 5) }\end{array}$ & County & $\begin{array}{l}\text { Latitude } \\
\text { (decimal } \\
\text { degrees) }\end{array}$ & $\begin{array}{c}\text { Longitude } \\
\text { (decimal } \\
\text { degrees) }\end{array}$ & $\begin{array}{l}\text { Number of } \\
\text { samples } \\
\text { (one or more } \\
\text { constituents) }\end{array}$ & $\begin{array}{l}\text { Range of } \\
\text { years for } \\
\text { collected } \\
\text { samples }\end{array}$ \\
\hline Blanco River at Wimberley, Tex. & 08171000 & Hays & 29.994381 & -98.088898 & 42 & $1996-98$ \\
\hline Olmos Creek tributary at FM 1535, Shavano Park, Tex. & 08177600 & Bexar & 29.576617 & -98.546130 & 6 & 1997-98 \\
\hline $\begin{array}{l}\text { Stone Mountain Drainage Channel at Granite Path, San } \\
\text { Antonio,Tex. }\end{array}$ & 08178595 & Bexar & 29.648559 & -98.501407 & 12 & 1996-2008 \\
\hline Camp Creek at Wilderness Trail, San Antonio, Tex. & 08178602 & Bexar & 29.636614 & -98.531130 & 12 & $1998-2007$ \\
\hline Lorence Creek at Donella Drive, San Antonio, Tex. & 08178610 & Bexar & 29.599671 & -98.478906 & 8 & 1996-98 \\
\hline $\begin{array}{l}\text { Elm Waterhole Creek at Evans Road near San Antonio, } \\
\text { Tex. }\end{array}$ & 08178625 & Bexar & 29.648003 & -98.411405 & 1 & 2000 \\
\hline Medina River near Riomedina, Tex. & 08180500 & Medina & 29.498000 & -98.905500 & 5 & 1996 \\
\hline Government Canyon Creek site 2 near Helotes, Tex. & 08180941 & Bexar & 29.539167 & -98.751389 & 17 & $1997-2007$ \\
\hline Laurel Canyon Creek near Helotes, Tex. & 08180942 & Bexar & 29.556783 & -98.745989 & 5 & 2004-07 \\
\hline Leon Creek at Scenic Loop Road near Leon Springs, Tex. & 08180945 & Bexar & 29.675556 & -98.675833 & 7 & $2001-07$ \\
\hline Leon Creek at Hausman Road, San Antonio, Tex. & 08180947 & Bexar & 29.571944 & -98.619167 & 9 & $2001-04$ \\
\hline Leon Creek at Prue Road, San Antonio, Tex. & 08181050 & Bexar & 29.541389 & -98.631667 & 15 & 2000-2007 \\
\hline Helotes Creek at Helotes, Tex. & 08181400 & Bexar & 29.578561 & -98.691690 & 22 & 1997-2007 \\
\hline Frio River at Concan, Tex. & 08195000 & Uvalde & 29.488565 & -99.704776 & 63 & 1996-2004 \\
\hline
\end{tabular}

of samples). These frequently detected contaminants include the pesticides atrazine, its degradate deethylatrazine (DEA), and simazine; the drinking-water disinfection byproduct chloroform (a trihalomethane); and the solvent tetrachloroethene (PCE) (commonly used in dry cleaning). Less frequently detected constituents (that is, detected in 5 to 20 percent of samples) include the pesticide prometon and the trihalomethanes bromodichloromethane and tribromomethane (bromoform). Other atrazine degradates, CEAT (deisopropylatrazine or 2-chloro-6-ethylamino-4-amino-s-triazine) and OIET (hydroxyatrazine or 2-hydroxy-4-isopropylamino-6-ethylamino-s-triazine), were analyzed only for samples from confined wells (2004-05) and were detected (either one or both) in 30 percent of these samples. Atrazine is the most heavily used herbicide in the United States, with both extensive agricultural application and urban application on residential lawns and ornamentals. Simazine and prometon are commonly found in herbicides used to control weeds in urban areas; simazine is also sometimes used in agricultural applications; prometon is used for nonagricultural weed control around fences, buildings, and roads (Gilliom and others, 2006). The EPA MCLs for atrazine and simazine are 3 and $4 \mu \mathrm{g} / \mathrm{L}$, respectively. There is currently no MCL for prometon. Atrazine, simazine, and prometon are among the most frequently detected herbicides in U.S. surface water and groundwater (Gilliom and others, 2006). Laboratory studies have indicated that low concentrations of atrazine in the environment result in endocrine disruption in amphibians, although this research is controversial (Hayes, 2004). Chloroform and other trihalomethanes are byproducts of drinking-water treatment 
processes. The EPA MCL for total trihalomethanes is $80 \mu \mathrm{g} / \mathrm{L}$. PCE is an industrial solvent primarily used in dry cleaning and metal degreasing and is also in household products such as paint and spot removers. The EPA MCL for PCE is $5 \mu \mathrm{g} / \mathrm{L}$.

Results for some organic compounds in USGS National Water Quality Laboratory Schedule 1433 (caffeine, phenol, benzophenone, and 4-nonylphenol) were not considered because of analytical limitations during the study period (Zaugg and Leiker, 2006). For example, standard methods for laboratory blank detections were not established until January 2006 for caffeine. Results for DEA were qualified as estimated ("E") by the National Water Quality Laboratory under laboratory reporting conventions used during the study period. A remark code of "E" was used when compounds were identified, but concentrations could not be accurately quantified for a variety of reasons. Analytical recoveries typically were lower than expected for DEA; therefore concentrations were qualified (Sandstrom and others, 2001). Discussion of anthropogenic contaminants in this report focuses on the five most frequently detected anthropogenic contaminants, atrazine, DEA, simazine, chloroform, and PCE.

\section{Geochemical Evolution Processes}

Interactive processes between fluid and rock in porous media (water-rock interaction) include mineral-solution reactions, diagenesis, and fluid mixing. Geochemical and isotopic data are useful tracers of water-rock interaction processes, recharge, groundwater flow, and fluid mixing that might affect water quality. Previous work in the Edwards aquifer provides a framework of understanding for regional-scale geochemical processes that affect and control spatial and temporal variability of fluid geochemistry, especially with respect to major and trace elements such as $\mathrm{Ca}, \mathrm{Mg}$, and $\mathrm{Sr}$ (for example, Oetting, 1995; Sharp and Banner, 1997; Musgrove and Banner, 2004; Wong and others, 2007). An understanding of geochemical evolution processes coupled with an evaluation of waterquality data provides information on groundwater residence times, endmember compositions and mixing processes, flow path length, and aquifer susceptibility to anthropogenic contaminants.

\section{Major/Trace Element Ratios}

Geochemical processes of water-rock interaction and progressive groundwater evolution in carbonate waters (for example, by processes of calcite recrystallization, incongruent dolomite dissolution, and prior precipitation of calcite along flow paths) can result in increases in $\mathrm{Mg} / \mathrm{Ca}$ and $\mathrm{Sr} / \mathrm{Ca}$ ratios with increasing groundwater residence time over multiple time scales (Plummer, 1977; Trudgill and others, 1980; Lohmann, 1988; Fairchild and others, 2000; Musgrove and Banner, 2004; Fairchild and others, 2006). Given this evolution pathway, $\mathrm{Mg} / \mathrm{Ca}$ and $\mathrm{Sr} / \mathrm{Ca}$ ratios in carbonate groundwater typically increase along flow paths. $\mathrm{Mg} / \mathrm{Ca}$ and $\mathrm{Sr} / \mathrm{Ca}$ ratios of Edwards aquifer groundwater samples were well correlated (Kendall's tau $=.61$ ) and increase from shallow/urban unconfined to unconfined to confined groundwater sample categories (fig. 7). For shallow/urban unconfined, unconfined, and confined groundwater sample categories, the median values for $\mathrm{Mg}$ / $\mathrm{Ca}\left(0.13,0.27,0.35\right.$, respectively) and for $\mathrm{Sr} / \mathrm{Ca}\left(\mathrm{x} 10^{3}\right)(0.59$, $1.67,3.08$, respectively) are statistically different on the basis of Mann-Whitney U test results. These differences among $\mathrm{Mg} / \mathrm{Ca}$ and $\mathrm{Sr} / \mathrm{Ca}$ ratios are consistent with longer residence times and greater extents of water-rock interaction processes controlling fluid compositions as groundwater evolves from shallow unconfined groundwater to deeper confined groundwater. The ranges of $\mathrm{Mg} / \mathrm{Ca}$ and $\mathrm{Sr} / \mathrm{Ca}$ ratios for the three sample categories (shallow/urban unconfined, unconfined, and confined) overlap, however, suggesting that water-rock interaction processes are spatially variable and likely are affected by local-scale variations as a result of differences in host limestone composition, soil composition, flow routes, and residence times. Despite these local complexities that affect individual values, a distinct regional pattern is evident.

Water-rock interaction processes can be modeled using mass-balance relations, initial fluid and host rock compositions, and distribution coefficients $\left(\mathrm{K}_{\mathrm{D}}\right)$ for $\mathrm{Mg}$ and $\mathrm{Sr}$ partitioning (Banner and others, 1989; Banner and Hanson, 1990). An approach described in Musgrove and Banner (2004) for the progressive recrystallization of calcite and (or) dolomite was applied to these data; isotopic and elemental exchange is simulated by an iterative process of dissolution and reprecipitation of calcite or dolomite (with a constant composition that approximates that measured for central Texas carbonates) by a fluid of a defined initial composition (with a composition that approximates that measured for leachates of central Texas soils). Variations in model input parameters, such as trace element concentrations of the host rock, initial fluid composition, and trace element $\mathrm{K}_{\mathrm{D}}$, alter the resulting modeled pathway of fluid composition. Modeled fluid composition is based on a range of values measured regionally for soil leachates and surface waters (Bush and others, 2000; Musgrove and Banner, 2004). Mesozoic and Paleozoic limestones typically contain between 2 and 4 weight percent magnesium carbonate $\left(\mathrm{MgCO}_{3}\right)$ (Goldsmith and others, 1955). Measured trace element concentrations for Edwards Group limestones exhibit a range of $\mathrm{Sr}$ and $\mathrm{Mg}$ concentrations; mean values for $\mathrm{Sr}$ and $\mathrm{Mg}$ concentration and $\mathrm{MgCO}_{3}=140$ parts per million (ppm), $6,800 \mathrm{ppm}$, and 2.4 percent, respectively $(\mathrm{n}=12)$ (Kathryn M. Conko, U.S. Geological Survey, written commun., 2008). Modeled rock compositions are consistent with these measured values and results of other diagenetic studies and analyses of Edwards Group limestones (Fisher and Rodda, 1969; Rose, 1972; Petta, 1977; and Ellis, 1985).

Previous applications of fluid evolution models in the Edwards aquifer and in the Pleistocene limestone aquifer of Barbados have accounted for variable fluid compositions by water-rock interaction between groundwater and host rocks of varying composition (Banner and others, 1994; Musgrove 

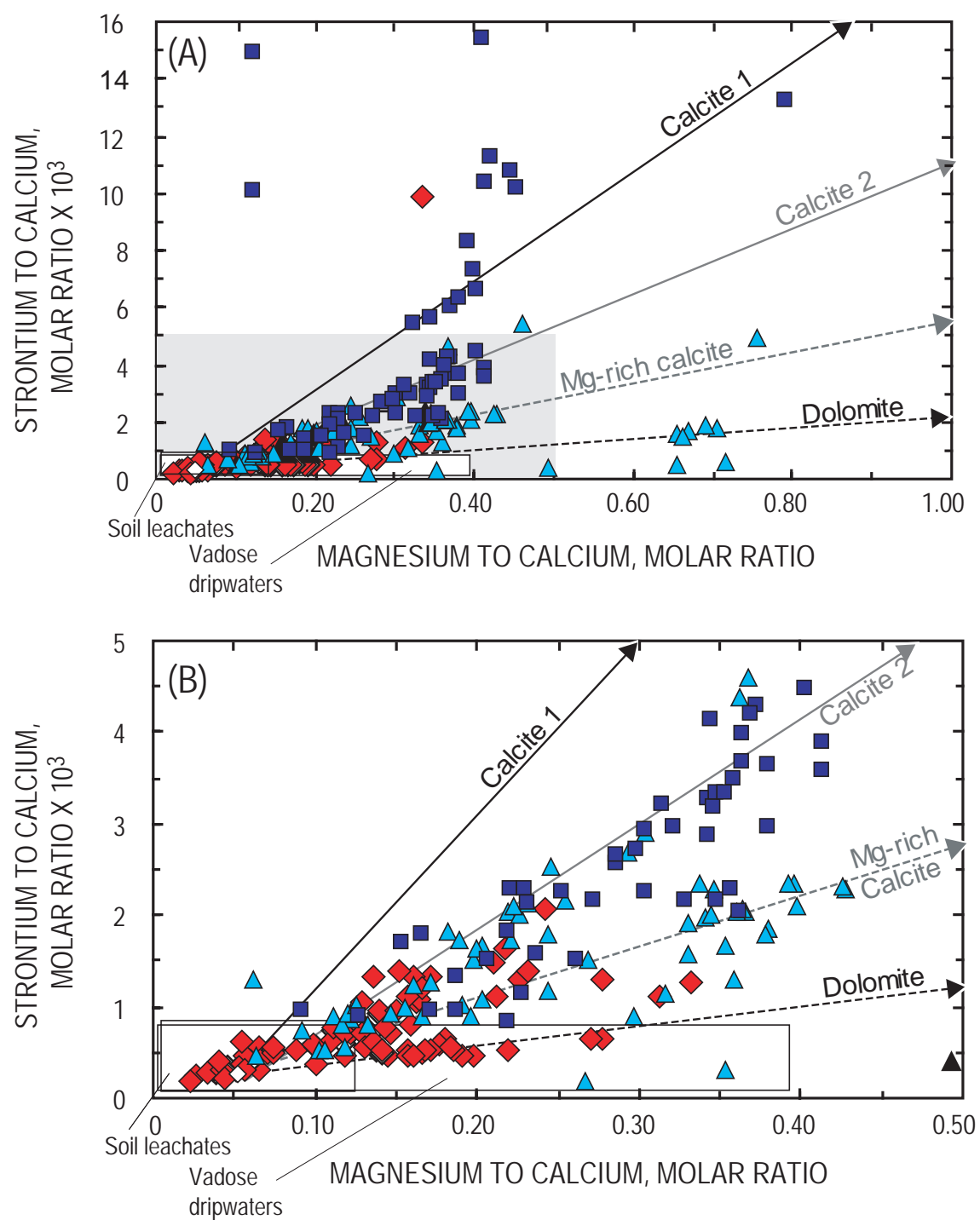

EXPLANATION

Water-rock interaction model curve

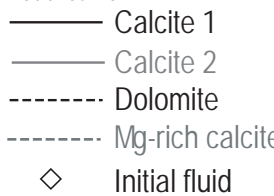

Groundwater

$\diamond$ Shallow/urban unconfined

$\triangle$ Unconfined

Confined

Figure 7. Relation between magnesium to calcium and strontium to calcium (molar ratios) for groundwater samples collected from shallow/urban unconfined, unconfined, and confined parts of the San Antonio segment of the Edwards aquifer, south-central Texas, 1996-2006; (A) full scale, and (B) shaded region in (A).

Fields for other aquifer components (soil leachates, vadose dripwaters) from M usgrove and Banner (2004). W ater-rock interaction model trajectories show the water evolution pathway for magnesium to calcium and strontium to calcium (molar ratios) for water that progressively recrystallizes calcite (1 and 2 denote different initial compositions), dolomite, or magnesium-rich ( $\mathrm{M}$ g-rich) calcite (as labeled). V ariations in model input parameters, such as trace element concentrations of host rock, initial water composition, and trace element distribution coefficients $\left(K_{D}\right)$ will alter the water model pathway; variable model trajectories shown account for majority of measured groundwater compositions.

Water/rock composition

Calcite 1 water composition

Calcite 1 rock composition

Calcite 2 water composition

Calcite 2 rock composition

Dolomite water composition

Dolomite rock composition

M g-rich calcite water composition

$\mathrm{Mg}$-rich calcite rock composition $\quad 50,000 \quad 1,000$
$K_{D}=0.01$ for strontium and magnesium in all model calculations.

Magnesium / strontium / calcium concentration (parts per million)

Modeled water and rock compositions consistent with measured values based on diagenetic studies and analyses of Edwards $\mathrm{G}$ roup limestones (K athryn M. Conko, U.S. Geological Survey, written commun., 2008; Fisher and Rodda, 1969; R ose, 1972; Petta, 1977; and Ellis, 1985). 


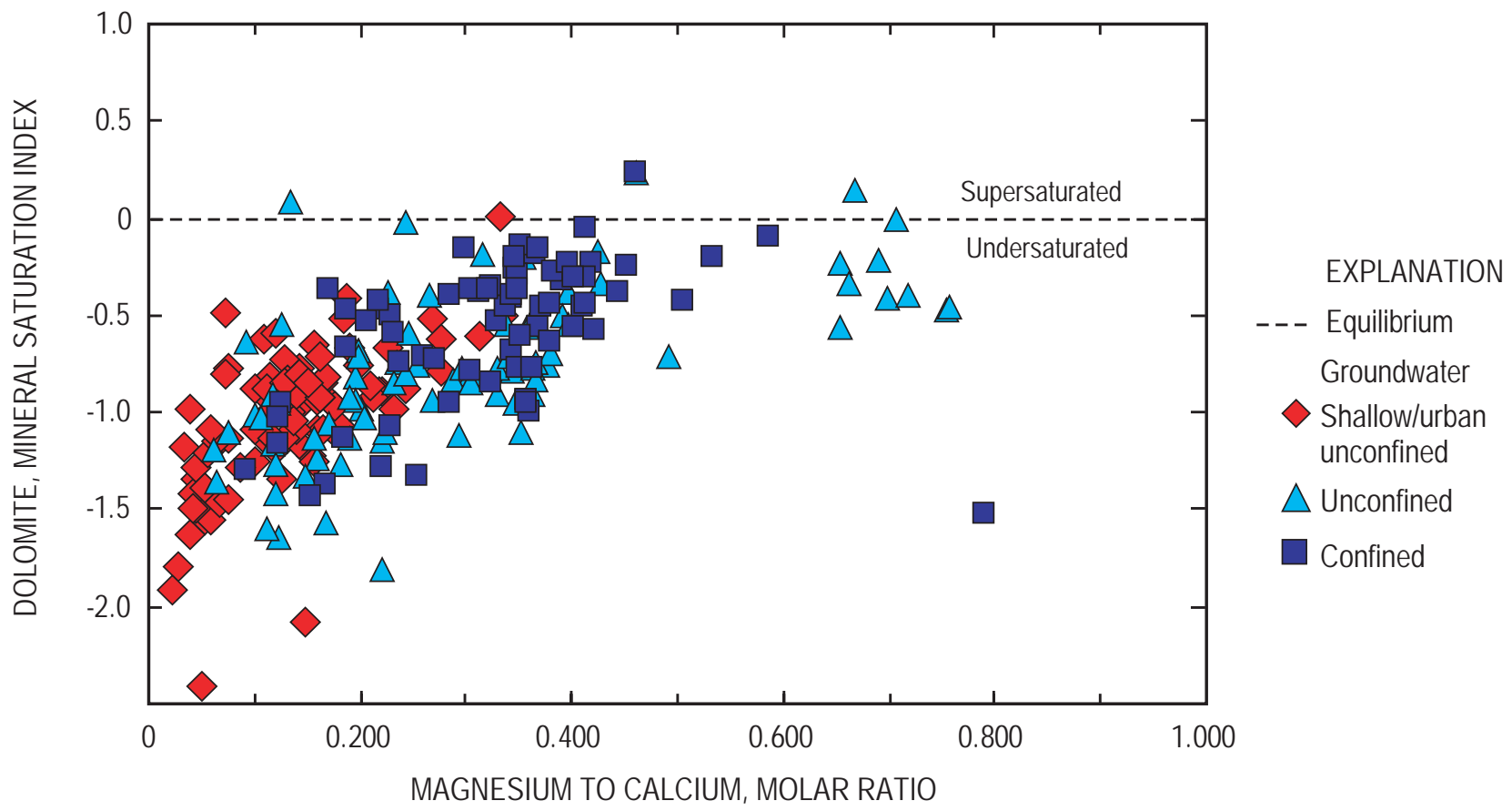

Figure 8. Relation between magnesium to calcium (molar ratio) and dolomite mineral saturation index for groundwater samples collected from shallow/urban unconfined, unconfined, and confined parts of the San Antonio segment of the Edwards aquifer, southcentral Texas, 1996-2006.

and Banner, 2004). Modeling results demonstrate that mineralsolution reactions with aquifer host rocks, shown by variable model trajectories, account for the majority of measured fluid compositions in Edwards aquifer groundwater (fig. 7). Variable initial rock compositions result in different model pathways, that is, trajectories with different slopes that better represent the range of data observed. These results are consistent with the hypothesis that local-scale variability in host limestone composition, soil composition, flow routes, and residence times results in a range of $\mathrm{Mg} / \mathrm{Ca}$ and $\mathrm{Sr} / \mathrm{Ca}$ ratios for Edwards aquifer groundwater. Nonetheless, a distinct regional pattern of increasing $\mathrm{Mg} / \mathrm{Ca}$ and $\mathrm{Sr} / \mathrm{Ca}$ ratios is evident as fluid evolves from shallow unconfined to deeper confined groundwater (fig. 7). Edwards aquifer rocks include both calcite and dolomite of variable composition; interaction with host rocks of variable composition is indicated by data that fall along different model pathways (fig. 7). At a local scale, water-rock interaction modeling might allow for distinguishing between flow paths.

Dolomite mineral SIs show a progression toward greater values, indicative of increasing mineral saturation, from shallow/urban unconfined to unconfined to confined category samples. Median dolomite SI values were $-1.0,-0.78$, and -0.47 for the shallow/urban unconfined, unconfined, and confined sample categories, respectively, and were statistically different on the basis of Mann-Whitney U test results. Dolomite SI results are an additional indicator of water-rock interaction processes and relative residence time. A correlation between dolomite SI values and $\mathrm{Mg} / \mathrm{Ca}$ ratios (Kendall's tau $=.52$ ) suggests that dolomite saturation in this aquifer is indicative of progressive water-rock interaction (fig. 8). High $\mathrm{Mg} / \mathrm{Ca}$ ratios (greater than 0.60) for a few samples from the unconfined and confined parts of the Edwards aquifer (fig. 8) are consistent with groundwater compositions that have been influenced by mixing with more saline groundwater, likely originating from the saline zone.

Precipitation of calcite along flow paths is an additional process that can result in increasing $\mathrm{Mg} / \mathrm{Ca}$ and $\mathrm{Sr} / \mathrm{Ca}$ ratios in residual groundwater as a result of the $\mathrm{K}_{\mathrm{D}}$ for $\mathrm{Mg}$ and $\mathrm{Sr}$ partitioning during mineral precipitation (Fairchild and others, 2006; Wong, 2008). This process is evident along the evolution pathway from shallow/urban unconfined to unconfined to confined Edwards aquifer groundwater with $\mathrm{Mg} / \mathrm{Ca}$ and $\mathrm{Sr} / \mathrm{Ca}$ ratios increasing as $\mathrm{Ca}$ concentrations decrease (fig. 9). Higher $\mathrm{Mg} / \mathrm{Ca}$ and $\mathrm{Sr} / \mathrm{Ca}$ ratios, in conjunction with lower $\mathrm{Ca}$ concentrations, result from the prior precipitation of calcite along flow paths and provide an additional indicator of increasing water-rock interaction and groundwater evolution.

Some unconfined groundwater samples had high $\mathrm{Mg} / \mathrm{Ca}$ ratios (greater than 0.60) that do not coincide with the main data trends (figs. 7-9). These data reflect multiple samples with high $\mathrm{Mg}$ concentrations measured in four wells in Hays and Comal Counties (18 to $31 \mathrm{mg} / \mathrm{L}$, relative to a median $\mathrm{Mg}$ concentration of $11.6 \mathrm{mg} / \mathrm{L}$ for all groundwater samples). The four wells in Hays and Comal Counties are in areas where the aquifer is characterized by extensive faulting; associated groundwater might be interacting with aquifer rocks of variable lithology (for example, more dolomitic) and (or) 


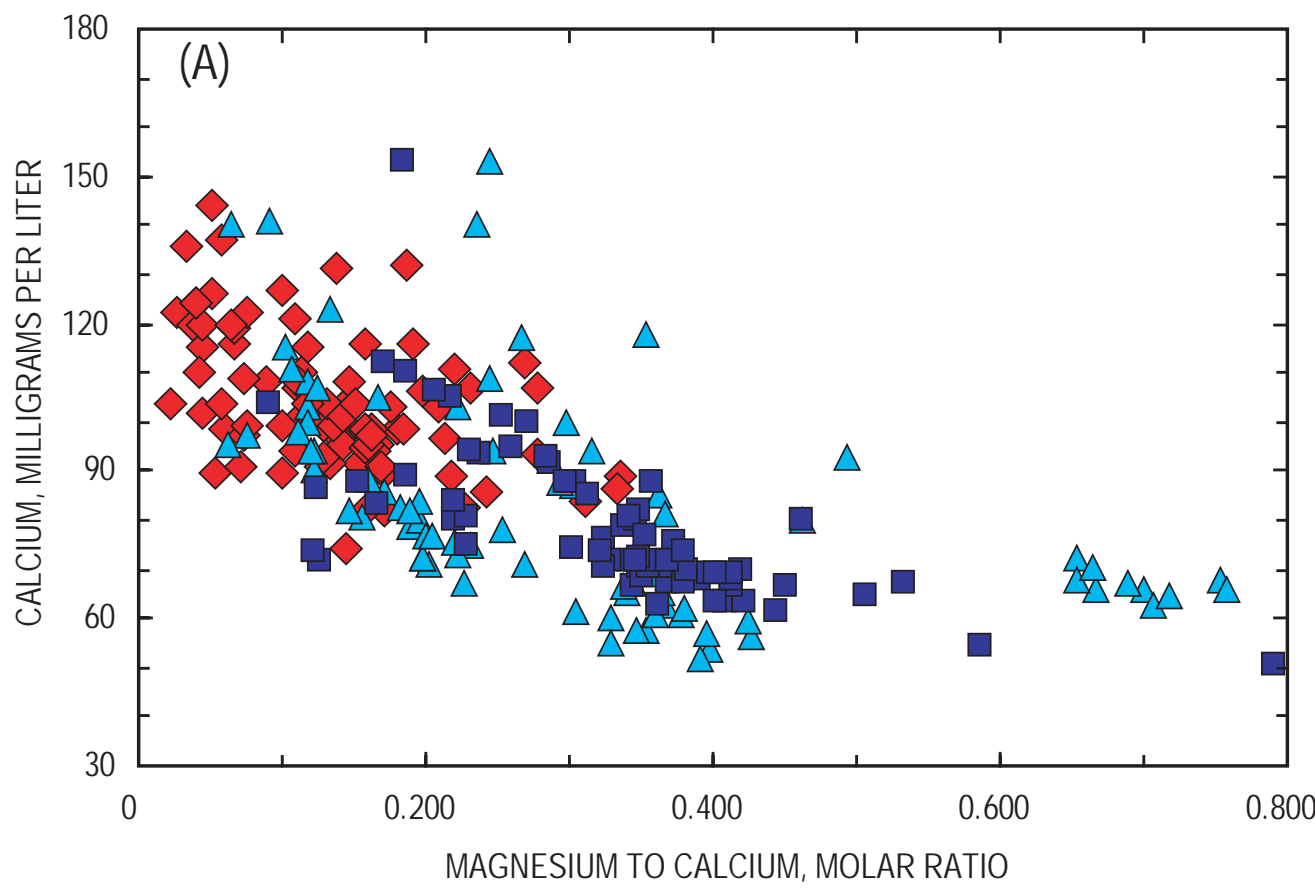

\section{EXPLANATION}

Groundwater

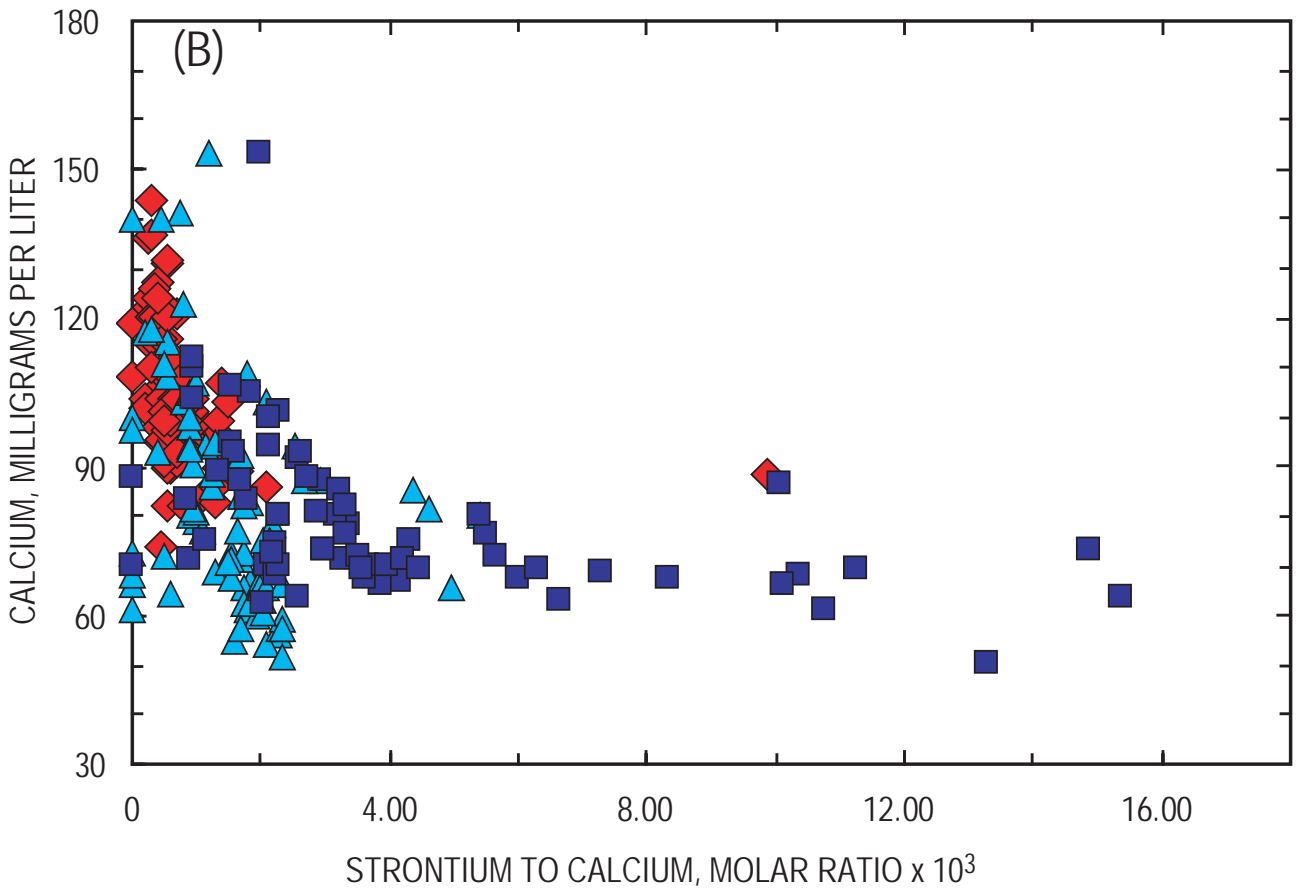

Shallow/urban unconfined

$\triangle$ Unconfined

Confined

Figure 9. Relation between (A) magnesium to calcium (molar ratio) and calcium concentration, and (B) strontium to calcium (molar ratio $\times 10^{3}$ ) and calcium concentration for groundwater samples collected from shallow/urban unconfined, unconfined, and confined parts of the San Antonio segment of the Edwards aquifer, 1996-2006.

mixing with downdip water moving along faults. As a result, groundwater from these wells can evolve along a different fluid evolution pathway, although from a similar starting point. Groundwater samples from several of the confined wells had high $\mathrm{Sr} / \mathrm{Ca}$ ratios as a result of particularly high $\mathrm{Sr}$ concentrations $(4,400$ to $7,160 \mu \mathrm{g} / \mathrm{L})$. These high $\mathrm{Sr}$ concentrations can result from interaction with variable host rock lithologies (for example, high-Sr limestone or trace amounts of Sr-rich minerals associated with the host rock, such as celestite [a trace mineral, sometimes associated with carbonate rocks, that is known to occur in Edwards aquifer rocks in the saline zone (Maclay and Small, 1983)]) and (or) mixing with deeper groundwater 
from the saline zone of the Edwards aquifer. Groundwater from the saline zone of the Edwards aquifer typically has higher $\mathrm{Sr}, \mathrm{SO}_{4}$, and $\mathrm{F}$ concentrations than groundwater from the freshwater zone (Oetting, 1995; Oetting and others, 1996; Mahler, 2008; Lambert and others, 2009; U.S. Geological Survey, 2009). Higher than average $\mathrm{SO}_{4}$ and $\mathrm{F}$ concentrations associated with some of these wells is also indicative of mixing with deeper, more saline groundwater.

\section{Strontium Isotopes}

$\mathrm{Sr}$, an alkali earth metal, commonly substitutes for $\mathrm{Ca}$ in low-temperature aqueous geochemical environments and is a common trace element in carbonate rocks (Hem, 1989; Banner, 2004). Sr has four isotopes, of which ${ }^{87} \mathrm{Sr}$ is derived from the radiogenic decay of rubidium-87; the $\mathrm{Sr}$ isotope ratio $\left({ }^{87} \mathrm{Sr} /{ }^{86} \mathrm{Sr}\right)$, a useful tracer in the hydrologic cycle, often provides a diagnostic signal of the source of dissolved constituents to a fluid (Banner, 2004). ${ }^{87} \mathrm{Sr} /{ }^{86} \mathrm{Sr}$ ratios in hydrology have been used to trace flow paths, mineral-solution reactions, and variations in recharge and flow routes in a number of different groundwater settings (McNutt and others, 1990; Banner and others, 1994). In the Edwards aquifer, Sr isotope ratios have been applied previously in conjunction with trace element ratios as a tracer of water-rock interaction, groundwater residence time, recharge, unsaturated zone flow-routes, and influence of soil composition on groundwater geochemistry (Oetting and others, 1996; Musgrove and Banner, 2004; Garner, 2005). Sr isotope ratios in the Edwards aquifer decrease with increasing water-rock interaction, from soil water, to unsaturated zone cave dripwater, to phreatic groundwater, approaching values similar to those of the host rock (Oetting and others, 1996; Sharp and Banner, 1997; Musgrove and Banner, 2004). Cretaceous-age carbonate host rocks that compose the Edwards aquifer have $\mathrm{Sr}$ isotope ratios ranging from 0.7074 to 0.7077 (Koepnick and others, 1985; Oetting, 1995). Higher ${ }^{87} \mathrm{Sr} /{ }^{86} \mathrm{Sr}$ ratios for groundwater relative to the aquifer host rocks are indicative of a source of more radiogenic $\mathrm{Sr}$ (enriched in ${ }^{87} \mathrm{Sr}$ ) to the groundwater, which has been proposed to be a result of chemical interaction of groundwater with overlying soils (Musgrove and Banner, 2004).

${ }^{87} \mathrm{Sr} /{ }^{86} \mathrm{Sr}$ analyses for NAWQA samples of Edwards aquifer groundwater were mostly limited to samples collected in 1996 from the unconfined part of the aquifer and samples collected in 2006 from the shallow/urban unconfined part of the aquifer. Sr isotope ratios ranged from 0.7076 to 0.7095 with a median value of $0.7082(\mathrm{n}=65) .{ }^{87} \mathrm{Sr} /{ }^{86} \mathrm{Sr}$ ratios for groundwater samples collected from the shallow/urban unconfined part of the aquifer are generally higher (median = $0.7084 ; \mathrm{n}=35$ ) than ${ }^{87} \mathrm{Sr} /{ }^{86} \mathrm{Sr}$ ratios for groundwater samples collected from the unconfined part of the aquifer (median $=$ $0.7079 ; n=27$ ) (table 3 ) and are statistically different on the basis of Mann-Whitney $U$ test results. Although the small number of analyses for groundwater samples collected from the confined part of the aquifer $(n=3)$ limit a comparison of these results with results for samples collected from other parts of the aquifer, Sr isotope ratios for confined groundwater samples $($ median $=0.7078)$ were lower than for samples from the unconfined part of the aquifer and were similar to ${ }^{87} \mathrm{Sr} /{ }^{86} \mathrm{Sr}$ ratios of the carbonate host rocks. Recent (2007) results for additional ${ }^{87} \mathrm{Sr} /{ }^{86} \mathrm{Sr}$ analyses $(\mathrm{n}=17)$ of samples collected from seven confined wells in Bexar County as part of the NAWQA TANC study have similar lower values in the range of Cretaceous-age host rocks (median $=0.7077)$ (Lynne Fahlquist, U.S. Geological Survey, written commun., 2009).

Using the modeling approach described by Musgrove and Banner (2004), fluid evolution processes are assessed using $\mathrm{Sr}$ isotopes in Edwards aquifer groundwater (fig. 10). Results demonstrate a progression toward lower ${ }^{87} \mathrm{Sr} /{ }^{86} \mathrm{Sr}$ ratios and higher $\mathrm{Mg} / \mathrm{Ca}$ ratios with increased mineral-solution reaction as allowed by increased residence time and longer flow paths. The relation between ${ }^{87} \mathrm{Sr} /{ }^{86} \mathrm{Sr}$ ratios and $\mathrm{Sr} / \mathrm{Ca}$ ratios demonstrates a similar progressive evolution pathway. These trends are consistent with previous research that also includes other aquifer components such as soils $\left({ }^{87} \mathrm{Sr} /{ }^{86} \mathrm{Sr}\right.$ $=0.7084$ to 0.7093 ) and unsaturated zone cave dripwaters $\left({ }^{87} \mathrm{Sr} /{ }^{86} \mathrm{Sr}=0.7080\right.$ to 0.7091 ; Oetting, 1995; Musgrove, 2000; Musgrove and Banner, 2004; Wong, 2008). This evolution of aquifer geochemistry might occur at different scales, both spatially and temporally, depending on variations in fluid-rock interaction, prior precipitation of calcite along flow paths, groundwater mixing, aquifer rock mineralogy, and hydrologic conditions; nonetheless, geochemical results indicate that controlling processes on groundwater evolution are regionally extensive. Higher ${ }^{87} \mathrm{Sr} /{ }^{86} \mathrm{Sr}$ ratios for the shallow/urban unconfined groundwater relative to deeper unconfined and confined groundwater are consistent with a characterization of shallow/urban unconfined groundwater as less geochemically evolved; shallow/urban unconfined groundwater is similar in composition to unsaturated zone cave dripwater (fig. 10). This might be accounted for by shorter residence times, shorter flow paths, and (or) a smaller component of diffuse flow. The consideration of NAWQA studies data for Edwards aquifer groundwater samples supports and further refines the interpretation of a regional-scale continuum of fluid evolution processes that control water compositions in the Edwards aquifer with fluid compositions evolving from soil water, to unsaturated zone cave dripwater, to shallow unconfined groundwater, to deeper unconfined groundwater.

\section{Stable Isotopes}

Stable isotope ratios of hydrogen and oxygen are commonly used to study hydrologic processes and have been applied to assess groundwater origin, mixing, and evaporation, hydrograph separation, and the response of karst systems to storms, aquifer recharge, subsurface flow routing (diffuse relative to conduit), and antecedent conditions (Craig, 1961; Gat, 1981; Lakey and Krothe, 1996; Jones and others, 2000; Desmarais and Rojstaczer, 2002; Maloszewski and others, 2002). $\delta$ D and $\delta^{18} \mathrm{O}$ for NAWQA samples of Edwards aquifer groundwater range from -36.0 to -15.2 per mil and -6.03 to 
(A)

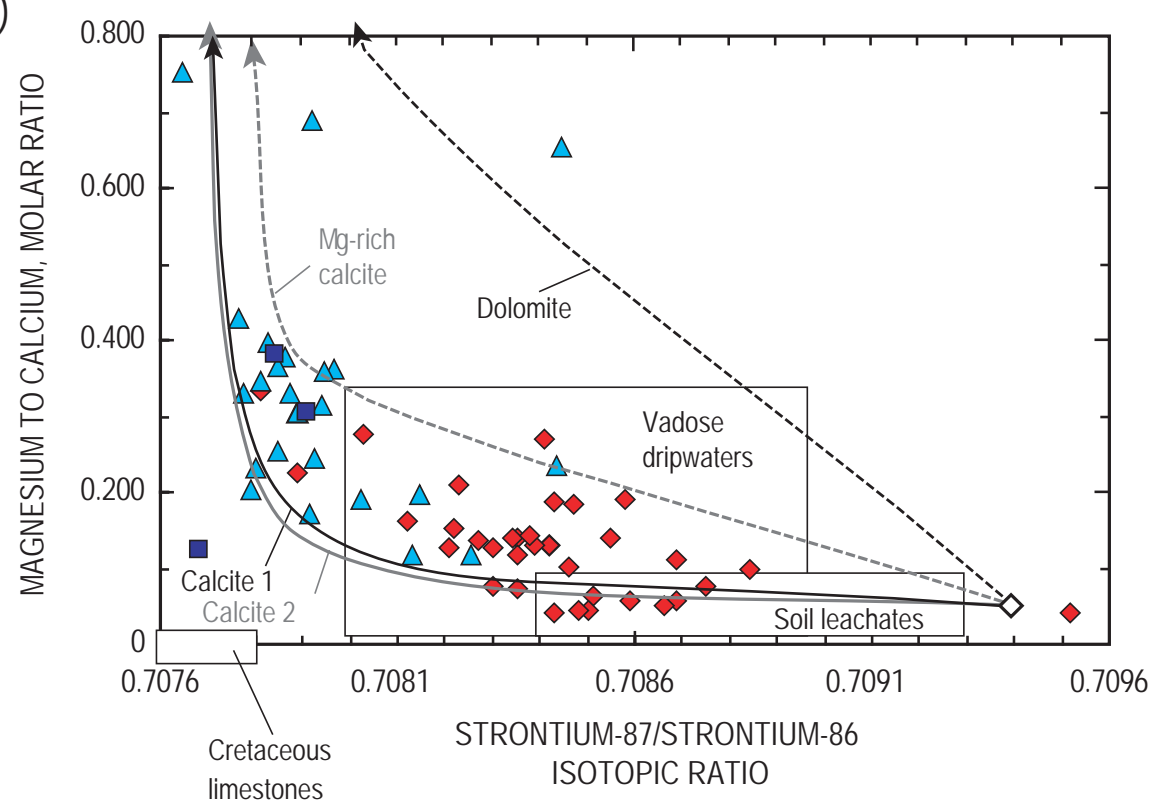

(B)

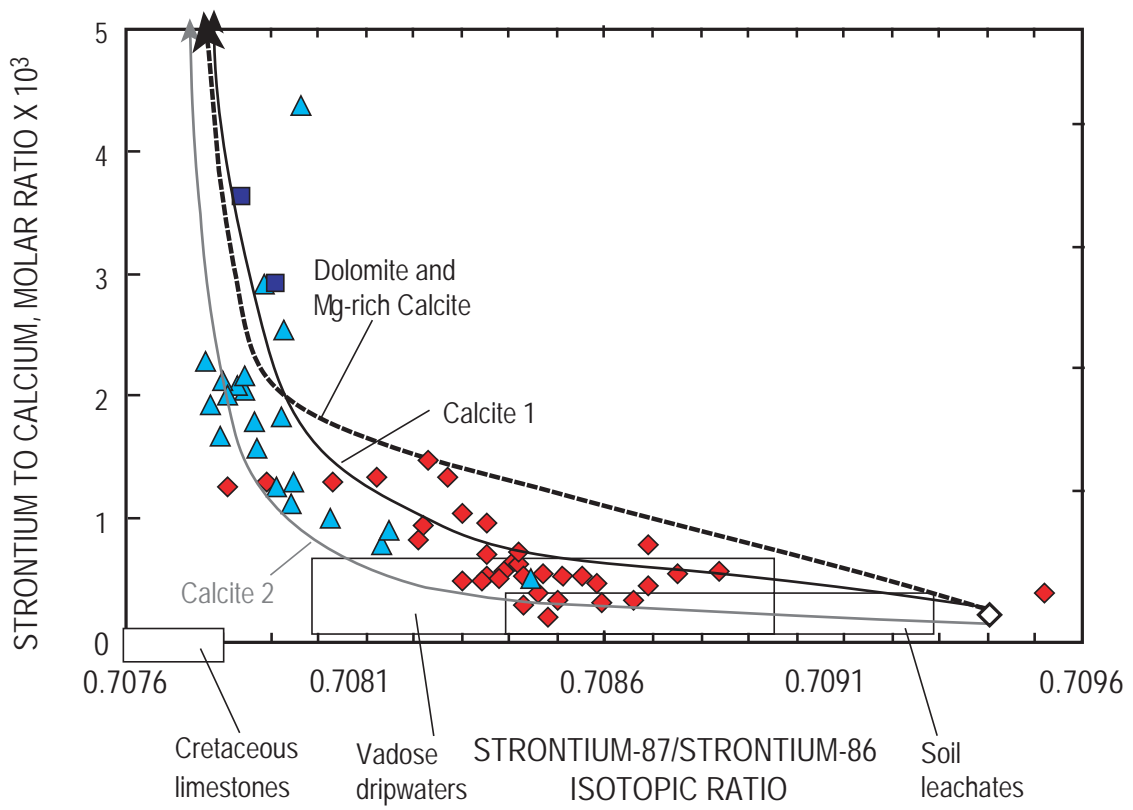

EXPLANATION

Water-rock interaction model curve

- Calcite 1

Calcite 2

----- Dolomite

------ Mg-rich calcite

$\diamond$ Initial fluid

Groundwater

$\diamond$ Shallow/urban unconfined

$\triangle$ Unconfined

- Confined

Figure 10. Relation between (A) strontium-87/strontium-86 isotopic ratio and magnesium to calcium (molar ratio) and (B) strontium-87/ strontium-86 isotopic ratio and strontium to calcium (molar ratio $\times 10^{3}$ ) for groundwater samples collected from shallow/urban unconfined, unconfined, and confined parts of the San Antonio segment of the Edwards aquifer, south-central Texas, 1996-2006.

Fields for other aquifer components (soil leachates, vadose dripwaters, and Cretaceous limestones) from M usgrove and Banner (2004). M odel trajectories show water evolution pathway for water that progressively recrystalizes calcite ( 1 and 2 denote different initial compositions), dolomite, or magnesium-rich (M g-rich) calcite (as labeled). I nital water composition based on range of values measured for soil leachates and surface waters (Bush and others, 2000; M usgrove and Banner, 2004). V ariations in model input parameters, such as trace element concentrations of host rock, initial water composition, and trace element distribution coefficients $\left(\mathrm{K}_{\mathrm{D}}\right)$ will al ter the water model pathway; variable model trajectories shown account for the majority of measured groundwater compositions. Initial water and rock concentrations of magnesium, strontium, and calcium detailed in figure 7. Initial strontium-87/strontium-86 isotopic ratios are 0.7094 and 0.7077 for water and rock, respectively, for all model runs. Modeled water and rock compositions consistent with measured values based on diagenetic studies and analyses of Edwards Group limestones (K athryn M. Conko, U.S. G eological Survey, written commun., 2008; Fisher and R odda, 1969; Rose, 1972; Petta, 1977; and Ellis, 1985). 
-2.64 per mil, respectively, and cluster around median values of -23.8 and -4.26 per mil $(n=168)$. A comparison of these data with the global meteoric water line (MWL), which represents the isotopic composition of rainfall around the globe (Craig, 1961), indicates that Edwards aquifer groundwater is composed of meteoric recharge (Fahlquist and Ardis, 2004). Confined groundwater shows less variability in $\delta \mathrm{D}$ and $\delta^{18} \mathrm{O}$ values relative to shallow/urban unconfined and unconfined groundwater, which is consistent with the characterization of confined groundwater as a deeper, well-mixed, phreatic endmember in the aquifer.

The relation between $\delta \mathrm{D}$ values and $\mathrm{Cl}$ concentrations, both conservative constituents, has been used to delineate mixing (Musgrove and Banner, 1993) and indicates that some groundwater samples are influenced by specific geochemical processes (fig. 11). Groundwater samples from wells that are affected by mixing with a saline component are indicated by elevated $\mathrm{Cl}$ concentrations (more than $30 \mathrm{mg} / \mathrm{L}$ ) (fig. 11). Many confined groundwater samples have elevated $\mathrm{Cl}$ concentrations (median value for confined groundwater samples $=$ $17.4 \mathrm{mg} / \mathrm{L})$ relative to the median value for all samples $(12.7$ $\mathrm{mg} / \mathrm{L})$; this difference is statistically significant on the basis of Mann-Whitney U test results. Slightly elevated $\mathrm{Cl}$ concentrations for confined groundwater samples likely indicate mixing with a component of saline groundwater. Samples with the highest $\mathrm{Cl}$ concentrations (more than $30 \mathrm{mg} / \mathrm{L}$ ), however, are mostly from unconfined groundwater. These samples represent the same small group of wells in Hays and Comal Counties discussed earlier that have higher-than-average $\mathrm{Mg}$ concentrations. As previously discussed, these wells are located in areas where the aquifer is extensively faulted and groundwater might be mixing with more saline downdip water moving along faults. Some samples collected in 2006 from the shallow/urban unconfined part of the aquifer also have slightly elevated $\mathrm{Cl}$ concentrations (greater than $20 \mathrm{mg} / \mathrm{L}$ to as high as $45 \mathrm{mg} / \mathrm{L}$ ), likely a result of anthropogenic sources of $\mathrm{Cl}$.

A number of samples, mostly categorized as unconfined groundwater, had higher (isotopically heavier) $\delta \mathrm{D}$ values than the main field of data (greater than or equal to -20 per mil) (fig. 11). Higher $\delta \mathrm{D}$ values indicate that some of groundwater was subject to more evaporation losses relative to the bulk of the groundwater with lower $\delta \mathrm{D}$ values (Welhan, 1987). Higher $\delta \mathrm{D}$ values for the samples collected from wells in Uvalde and Medina Counties in the western part of the aquifer are indicative of recharge from surface-water streams or reservoirs that have undergone evaporation and possibly share a common flow path or flow paths. Previous research has proposed a flow path in northern Medina and northeastern Uvalde Counties with a component of water (recharged by Medina Lake; fig. 1) that is characterized by higher stable isotope values as a result of evaporation (Clark and Journey, 2006).

A number of samples collected from shallow/urban unconfined category wells were isotopically heavier, or had lower $\delta \mathrm{D}$ values than the main field of data (less than or equal to 27 per mil) (fig. 11). These lower $\delta \mathrm{D}$ values likely represent recharge dominated by tropical cyclonic storms. Rainfall associated with tropical cyclonic storms has been shown to have isotopically lighter stable isotope $\left(\delta \mathrm{D}\right.$ and $\left.\delta^{18} \mathrm{O}\right)$ values relative to normal summer rainfall (Lawrence and Gedzelman, 1996; Lawrence, 1998). These samples from shallow/urban unconfined category wells were collected in early to midNovember 1998, shortly following a large tropical storm in the area (more than $21 \mathrm{in}$. of rain were recorded at the San Antonio airport between October 1, 1998, and November 15, 1998). The isotopically light $\delta \mathrm{D}$ values for samples collected from these wells in urban Bexar County might indicate they share a common conduit-influenced flow path or flow paths that are dominated by recent surface recharge. These wells were resampled in 2006 under different hydrologic conditions; $\delta \mathrm{D}$ values lower than the median $\delta \mathrm{D}$ isotopic composition were not observed. These results are consistent with the hypothesis that hydrologic conditions affect groundwater geochemistry and water quality.

\section{Salinity Sources}

In the freshwater part of the aquifer, geochemical data indicate that groundwater in some wells mixes with more saline water. Groundwaters from the downdip saline zone and from the underlying Trinity aquifer are potential sources of higher salinity water that might mix with fresh Edwards aquifer groundwater. Understanding the source of this saline component, locally and regionally, has implications for hydrologic flow paths, water-use management, and understanding of the freshwater/saline-water transition zone. Previous studies have investigated the origin of saline-zone groundwater and have delineated distinct hydrochemical facies on the basis of variations in major element concentrations (Pearson and Rettman, 1976; Clement and Sharp, 1988; Sharp, 1990; Groschen and Buszka, 1997). The integration of variations in $\mathrm{Sr}$ isotope ratios, major element concentrations, and quantitative geochemical modeling has been used to evaluate models for the evolution of saline groundwater in the Edwards aquifer and corresponding depositional and structural controls (Oetting and others, 1996). Mixing processes involve freshwater, saline groundwater from underlying hydrostratigraphic units that migrate through faults and fractures, and brines associated with the Edwards Group migrating updip from the Cretaceous shelf margin (Oetting and others, 1996).

Edwards aquifer groundwater samples from parts of the aquifer that have a component of more saline water have higher (than the median) specific conductance values, typically accompanied by higher (than the median) concentrations of $\mathrm{Cl}, \mathrm{SO}_{4}$, and (or) $\mathrm{Na}$. Some saline-influenced groundwater also might have lower-than-average dissolved oxygen concentrations, and for the confined part of the aquifer, might be in close geographic proximity to the freshwater/saline-water transition zone. Differences in the geochemical characteristics of downdip water from the saline zone compared to that of the underlying Trinity aquifer groundwater, which also can be more saline than Edwards aquifer groundwater, have been used to distinguish between mixing with these two different 


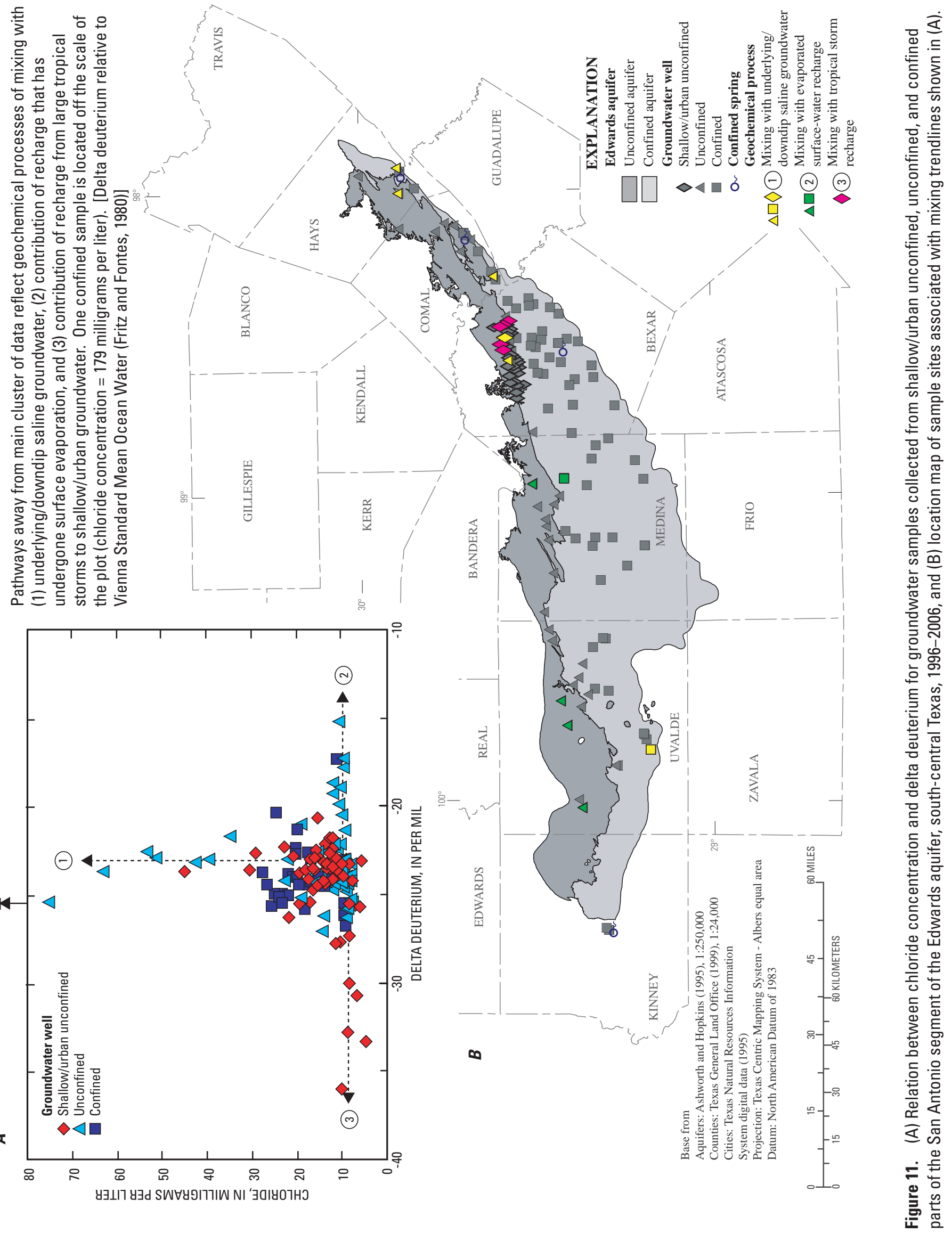


saline sources. Previous studies have indicated that Trinity aquifer groundwater, in comparison to downdip saline-zone water, is characterized by higher $\mathrm{SO}_{4}$ relative to $\mathrm{Cl}$, and higher $\mathrm{Mg}$ relative to $\mathrm{Na}$ (Sharp and Clement, 1988). Variations in the relation between $\mathrm{SO}_{4} / \mathrm{Cl}$ ratios and $\mathrm{SO}_{4}$ concentration and between $\mathrm{Mg} / \mathrm{Na}$ ratios and $\mathrm{Mg}$ concentration have been applied in the Barton Springs segment of the Edwards aquifer to distinguish between mixing with Trinity aquifer groundwater or with saline-zone groundwater (Garner, 2005; Garner and Mahler, 2007). Geochemical consideration of Trinity aquifer and saline-zone groundwater from the San Antonio segment of the aquifer with respect to these constituents indicates mixing pathways with Edwards aquifer groundwater (fig. 12). Trinity aquifer groundwater data were acquired from the USGS NWIS database (U.S. Geological Survey, 2009); these data are from a 1996 NAWQA study that sampled 31 wells completed in the Trinity aquifer and randomly located throughout the areal extent of the aquifer (Fahlquist and Ardis, 2004). Saline-zone groundwater data also were acquired from the USGS NWIS database (U.S. Geological Survey, 2009) and from San Antonio Water System (Hydrogeologic Studies and Assessment Division, written commun., 2009) for multiple samples collected from saline-zone transect wells in Bexar, Comal, and Hays Counties. Groundwater from several Edwards aquifer wells with mixed-saline characteristics (for example, high specific conductance, low dissolved oxygen) shows evidence for mixing with saline-zone groundwater or Trinity aquifer groundwater on the basis of the relation between the $\mathrm{SO}_{4} / \mathrm{Cl}$ ratio and $\mathrm{SO}_{4}$ concentration and (or) between the $\mathrm{Mg} / \mathrm{Na}$ ratio and $\mathrm{Mg}$ concentration (fig. 12).

High F concentration in Edwards aquifer groundwater samples is also indicative of mixing with groundwater from either the Trinity aquifer or the downdip saline zone; the median F concentration $(1.8 \mathrm{mg} / \mathrm{L} ; \mathrm{n}=31)$ for NAWQA samples of Trinity aquifer groundwater is about one order of magnitude higher than the median for Edwards aquifer groundwater samples $(0.14 \mathrm{mg} / \mathrm{L} ; \mathrm{n}=243)$. The F concentration, however, cannot be used to distinguish between mixing with saline-zone or Trinity aquifer groundwater. Similar to groundwater samples collected from the Trinity aquifer, samples from the Edwards aquifer saline zone also tended to have high $\mathrm{F}$ concentrations (median $=3.6 \mathrm{mg} / \mathrm{L}, \mathrm{n}=529$ ). Several of the NAWQA Edwards aquifer groundwater samples with characteristics indicative of some mixing with more saline water had relatively high $\mathrm{F}$ concentrations.

Mixing with underlying Trinity aquifer groundwater appears to be the dominant source of saline water for most of the NAWQA groundwater samples that show evidence for saline-water mixing (fig. 12). This distinction suggests that, on the basis of the relation between $\mathrm{SO}_{4} / \mathrm{Cl}$ ratios and $\mathrm{SO}_{4}$ concentrations and between $\mathrm{Mg} / \mathrm{Na}$ ratios and $\mathrm{Mg}$ concentrations, mixing with downdip saline groundwater might be an important salinity source only for Edwards aquifer groundwater wells near the saline zone. Data for a few NAWQA Edwards aquifer groundwater samples are not clearly associated with the mixing pathway for either Trinity aquifer groundwater or downdip saline-zone groundwater, which might indicate a more complex origin for their saline characteristics, such as mixing with both Trinity aquifer and saline-zone groundwater. Several of the NAWQA groundwater samples that show evidence for mixing with underlying Trinity aquifer groundwater are not characterized by higher specific conductance values as might be expected. One sample (collected June 5, 2001) from well AY-68-28-211, completed in the shallow/urban unconfined part of the aquifer and sampled multiple times, had an anomalously high $\mathrm{SO}_{4} / \mathrm{Cl}$ ratio associated with a high $\mathrm{SO}_{4}$ concentration (fig. 12). Given the shallow well construction, urban setting of this well, and lower values associated with other samples collected from this well, the anomalously high $\mathrm{SO}_{4} / \mathrm{Cl}$ ratio and $\mathrm{SO}_{4}$ concentration likely resulted from a local, transitory source of contamination.

Extensive water-rock interaction with gypsum, a trace mineral present in the Edwards Group, also might affect groundwater $\mathrm{SO}_{4} / \mathrm{Cl}$ ratios and $\mathrm{SO}_{4}$ concentrations; downdip saline-zone groundwater shows evidence of incongruent gypsum dissolution (Oetting and others, 1996). NAWQA sampled Edwards aquifer groundwater is highly undersaturated with respect to gypsum (mineral SI ranges from -2.96 to -1.49), indicating water that has not undergone extensive interaction with gypsum. Several samples with geochemical evidence for downdip saline-zone/Trinity aquifer groundwater mixing, however, are at the upper end of the gypsum SI range, which might indicate mixing with saline source waters that have undergone interaction with gypsum.

Evaluation of hydrologic conditions, local stratigraphy and structure (faults), well construction, and other groundwater geochemical and isotopic constituents can provide additional information for sampled wells with no readily distinguishable saline source. Proximity to the freshwater/ saline-water interface, however, does not necessarily indicate that mixing with downdip saline-zone water occurs. A number of Edwards aquifer wells, including high-production publicsupply wells, are near the freshwater/saline-water interface and show no geochemical indication of mixing with a saline-water component. Complex hydrostratigraphy limits the uniformity of mixing with saline-zone water and cross-formational flow in the aquifer, although Oetting and others (1996) notes that vertical fluid migration and mixing is more substantial in areas with reduced aquifer thickness and greater fault displacement.

\section{Radon}

The use of Rn concentration (radon-222) as an indicator of fast transport and rapid transit times is a developing application in karst studies (Hunkeler and Mudry, 2007; Falcone and others, 2008). Rn concentrations in karst groundwater likely originate in soils, and limestone host rocks are typically a poor source of Rn (Surbeck and Medici, 1991; Hunkeler and Mudry, 2007). Thus, Rn, which decays to low values in older, more evolved, confined groundwater might provide an indicator of residence time and (or) mixing with recent recharge. Given its short half-life of 3.8 days, Rn entering an aquifer 

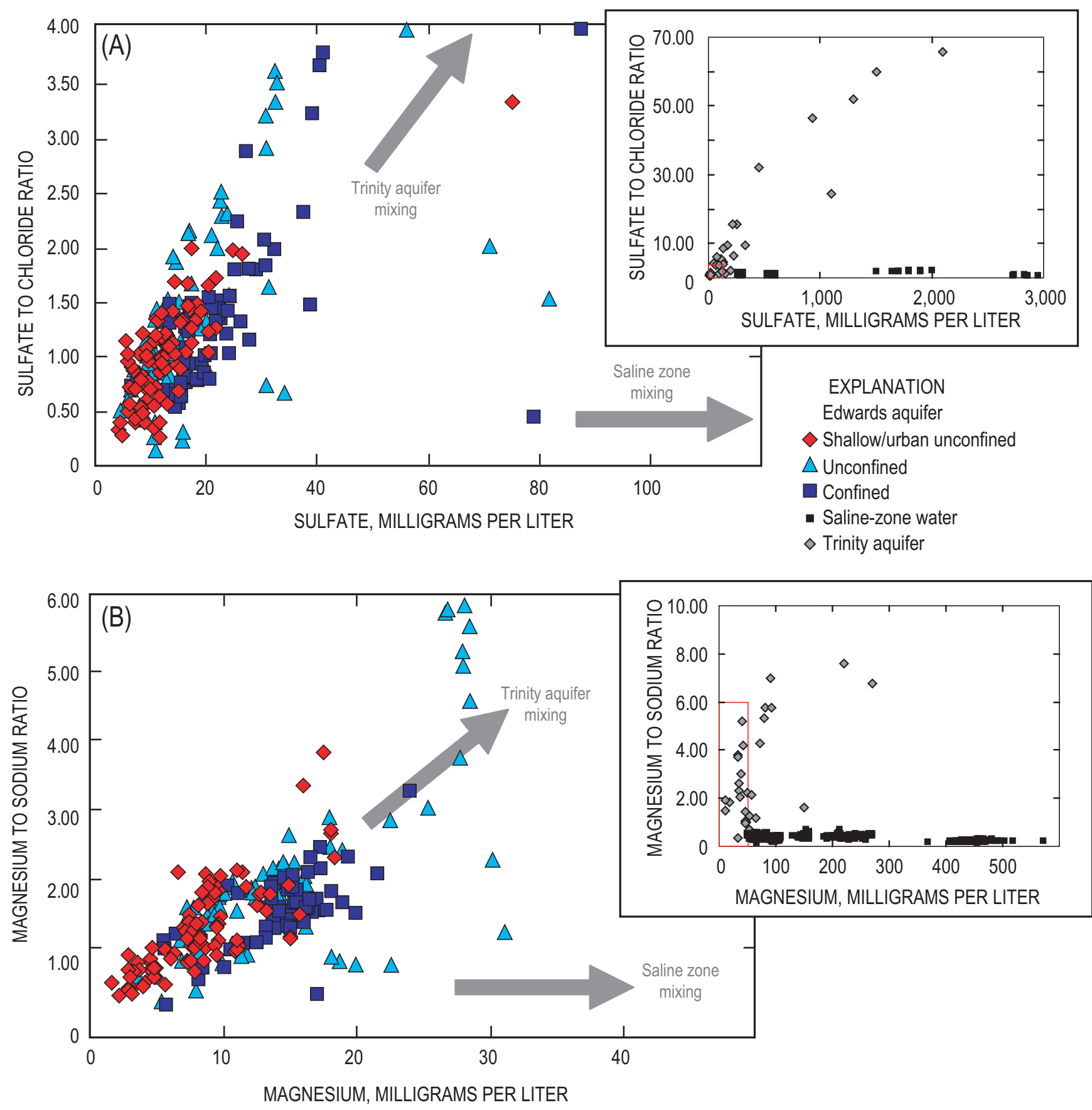

Figure 12. Relation between (A) sulfate to chloride ratio and sulfate concentration, and (B) magnesium to sodium ratio and magnesium concentration for groundwater samples collected from shallow/urban unconfined, unconfined, and confined parts of the San Antonio segment of the Edwards aquifer, south-central Texas, 1996-2006.

Trinity aquifer data from U.S. Geological Survey (2009) and saline-zone groundwater data from San A ntonio Water System (H ydrogeologic Studies and A ssessment Division, written commun., 2009). Red-bounded boxes in inserts denote scale expanded in (A) and (B). A rrows on $(A)$ and $(B)$ highlight mixing pathways with underlying Trinity aquifer groundwater (median sulfate to chloride ratio $=4.9 ;$ sulfate $=130$ milligrams per liter $(\mathrm{mg} / \mathrm{L}$ ); magnesium to sodium ratio $=2.2 ;$ magnesium $=48 \mathrm{mg} / \mathrm{L} ; n=31$ ) and downdip saline-zone groundwater in $B$ exar, Comal, and Hays Counties (median sulfate to chloride ratio $=1.04, n=376$; sulfate $=1,649 \mathrm{mg} / \mathrm{L}, \mathrm{n}=525$; magnesium to sodium ratio $=0.34$, $\mathrm{n}=395 ;$ magnesium $=371 \mathrm{mg} / \mathrm{L}, \mathrm{n}=371$ ). 


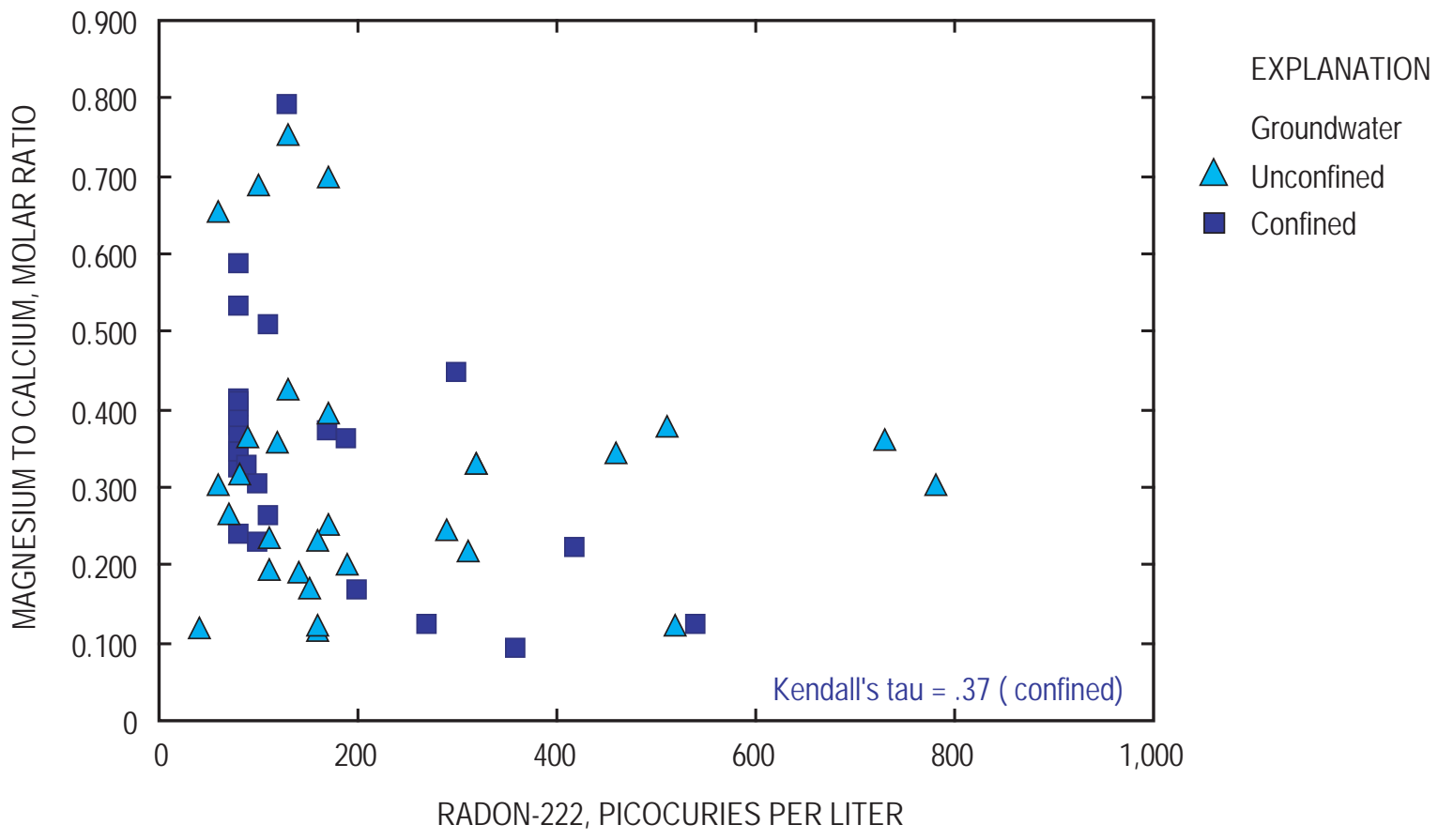

Figure 13. Relation between magnesium to calcium (molar ratio) and radon-222 for groundwater samples collected from unconfined and confined parts of the San Antonio segment of the Edwards aquifer, south-central Texas, 1996-2006.

with recharge water could decay to concentrations less than or equal to laboratory reporting levels within weeks to months (depending on the initial Rn concentration). Increases in $\mathrm{Rn}$ concentrations in spring water associated with an antecedent storm event, recent recharge, and a correlation between Rn concentrations and spring discharge have been shown for springs in the Swiss Jura karst system (Eisenlohr and Surbeck, 1995).

Rn concentrations from NAWQA Edwards aquifer groundwater samples range from less than 58 to 776 picocuries per liter $(\mathrm{pCi} / \mathrm{L})$ with a median value of $116 \mathrm{pCi} / \mathrm{L}$. Median values for samples from unconfined wells $(151 \mathrm{pCi} / \mathrm{L})$ are higher than for samples from confined wells $(89 \mathrm{pCi} / \mathrm{L})$ and are statistically different on the basis of Mann-Whitney U test results. Rn was not measured at shallow/urban unconfined sites. Results for Rn concentrations from NAWQA Edwards aquifer groundwater samples indicate that $\mathrm{Rn}$ in this system might provide an indicator of recent recharge and (or) rapid flow paths. $\mathrm{Mg} / \mathrm{Ca}$ ratios were correlated with $\mathrm{Rn}$ concentrations for confined groundwater samples (Kendall's tau $=-.37$ ) but showed no significant correlation for unconfined groundwater (fig. 13). Both $\mathrm{Mg} / \mathrm{Ca}$ ratios and $\mathrm{Rn}$ concentrations were correlated with well depth for confined groundwater samples; samples from deeper wells have lower Rn concentrations and higher $\mathrm{Mg} / \mathrm{Ca}$ ratios (fig. 14; Kendall's tau = -.34 and .42 , respectively). There is no significant correlation between well depth and Rn concentration for unconfined groundwater samples or between well depth and $\mathrm{Mg} / \mathrm{Ca}$ ratios for shallow/urban unconfined and unconfined groundwater samples.
The interpretation of Rn concentration data for several Edwards aquifer confined groundwater samples is likely complicated by potential sources from mixing with saline waters and (or) proximity to Tertiary volcanics in the western part of the aquifer. These sources might account for some high $\mathrm{Rn}$ concentrations in unconfined groundwater samples, as shown on figures 13 and 14. Although no Rn data for saline-zone groundwater is available for comparison, NAWQA groundwater samples from the Trinity aquifer collected in 1996 (Fahlquist and Ardis, 2004) have a higher median Rn concentration $(295 \mathrm{pCi} / \mathrm{L})$ than Edwards aquifer groundwater (statistically different on the basis of Mann-Whitney U test results). Several unconfined groundwater samples with high Rn concentrations correspond to the samples in Hays and Comal Counties with other geochemical indicators of salinezone influence. These results suggest that underlying saline water might be a potential source of Rn to Edwards aquifer groundwater. Future research should provide new insights into the utility of Rn as a tracer of recent recharge in the Edwards aquifer.

\section{Water-Quality Observations}

\section{Nitrate: Occurrence and Trends}

Anthropogenic activity has transformed the modern global nitrogen cycle, and elevated nutrient concentrations 


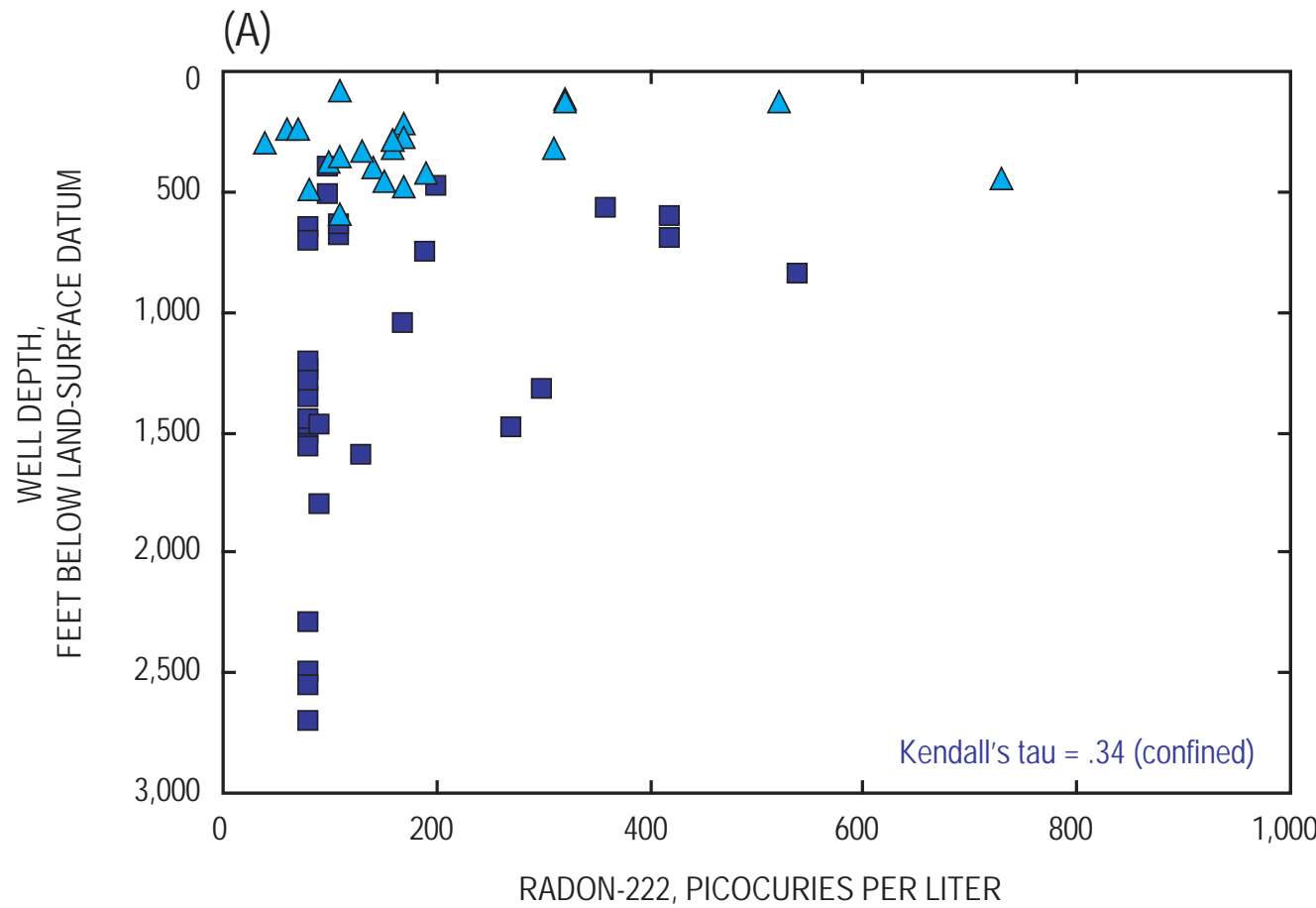

EXPLANATION Groundwater Shallow/urban unconfined

(B)

$\triangle$ Unconfined

Confined

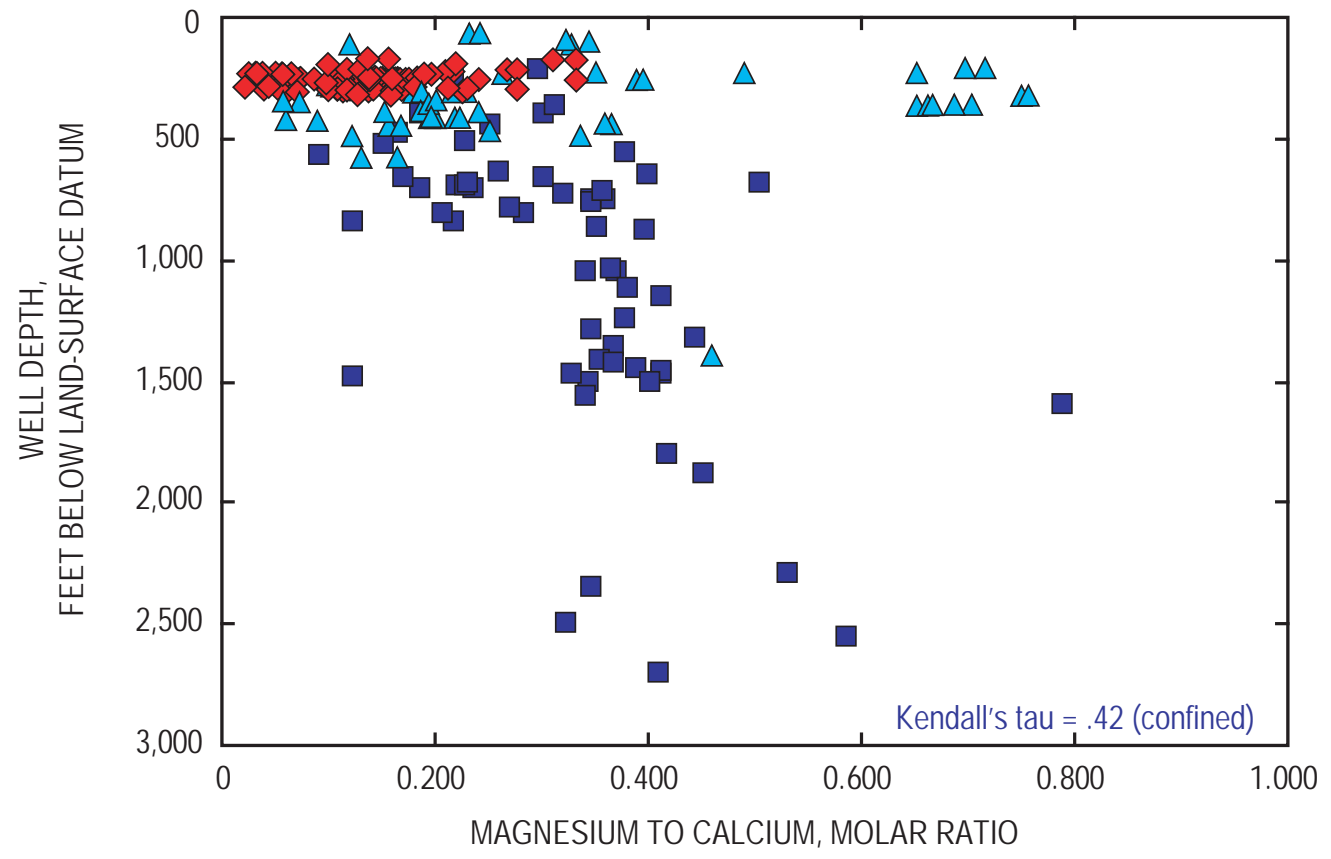

Figure 14. Relation between well depth and (A) radon-222 and (B) magnesium to calcium (molar ratio) for groundwater samples collected from shallow/urban unconfined, unconfined, and confined parts of the San Antonio segment of the Edwards aquifer, southcentral Texas, 1996-2006.

in water resources are an issue of worldwide concern (Schlesinger and others, 2006; Galloway and others, 2008). Nitrogen (N) is the most soluble of these nutrients (Hem, 1989), and nitrate $\left(\mathrm{NO}_{3}\right)$ frequently is elevated in water resources as a result of anthropogenic activities.
Anthropogenic $\mathrm{NO}_{3}$ sources include agricultural fertilizers, animal wastes, septic systems, municipal sewage-treatment systems, leaking sewer lines, and nitrogen oxide emissions. Atmospheric deposition, decaying organic matter, and soil mineralization processes also are potential $\mathrm{NO}_{3}$ sources. 
Natural $\mathrm{NO}_{3}$ sources are not common in limestone and dolomitic aquifer rocks, thus $\mathrm{NO}_{3}$ concentrations greater than the prevailing background concentration commonly represent anthropogenic sources.

$\mathrm{NO}_{3}$ concentrations in NAWQA Edwards aquifer groundwater samples (1996-2006) range from less than 0.05 to 8.23 $\mathrm{mg} / \mathrm{L}$, with a median value of $1.67 \mathrm{mg} / \mathrm{L}(\mathrm{n}=240)$. Nitrite $\left(\mathrm{NO}_{2}\right) \mathrm{N}$ was detected rarely and when detected was at low concentrations (less than 0.01 to $0.06 \mathrm{mg} / \mathrm{L}$ ), substantially less than $\mathrm{NO}_{3}$. $\mathrm{NO}_{3}$ concentrations greater than $3 \mathrm{mg} / \mathrm{L}$ were measured in less than 5 percent of all samples collected; these samples with relatively high $\mathrm{NO}_{3}$ (more than $3 \mathrm{mg} / \mathrm{L}$ ) likely are affected by local $\mathrm{NO}_{3}$ sources. Groundwater samples with relatively high $\mathrm{NO}_{3}$ concentrations were not restricted to any one sample category, but rather included the shallow/urban unconfined, unconfined, and confined categories. Samples of groundwater from the shallow/urban unconfined and confined categories had higher median $\mathrm{NO}_{3}$ concentrations $(1.85 \mathrm{mg} / \mathrm{L}$, $\mathrm{n}=90$; and $1.84 \mathrm{mg} / \mathrm{L}, \mathrm{n}=70$, respectively) than samples from the unconfined category (median $\mathrm{NO}_{3}$ concentration of $1.09 \mathrm{mg} / \mathrm{L}, \mathrm{n}=80$ ), and $\mathrm{NO}_{3}$ concentrations for unconfined groundwater samples were statistically different on the basis of Mann-Whitney U test results. The higher $\mathrm{NO}_{3}$ concentrations for samples in the shallow/urban unconfined category likely reflect a greater anthropogenically-derived influx of $\mathrm{NO}_{3}$ in the urban environment coinciding with the shallow/urban unconfined part of the aquifer. The median $\mathrm{NO}_{3}$ concentration measured in groundwater samples from the confined part of the aquifer was similar to that for samples from the shallow/urban unconfined part of the aquifer; some of the confined aquifer wells are in areas where the land use is agricultural. Short-circuiting through wellheads has been shown to provide a potential pathway through confining layers or thick overlying units (McMahon and others, 2008; Landon and others, 2009). It is unlikely, however, that this process would affect the confined aquifer across the region, but rather might result in higher $\mathrm{NO}_{3}$ concentrations at a few wells in agricultural areas. The concentrations of $\mathrm{NO}_{3}$ observed in the confined Edwards aquifer likely result from the long-term leaching of $\mathrm{NO}_{3}$ from soils into the aquifer matrix. Lower $\mathrm{NO}_{3}$ concentrations in the unconfined Edwards aquifer might reflect the location of these sampling sites in predominantly rural and rangeland areas, with little influence from anthropogenic $\mathrm{NO}_{3}$ sources and dilution of ambient $\mathrm{NO}_{3}$ by surfacewater recharge.

There is considerable interest in understanding $\mathrm{NO}_{3}$ sources and fate, including an understanding of natural background concentrations and historical trends for many karst aquifers that supply drinking water, including the Edwards aquifer. Variability in $\mathrm{NO}_{3}$ concentrations in response to hydrologic conditions, however, complicates the interpretation of temporal trends. The median $\mathrm{NO}_{3}$ concentration for groundwater samples collected from shallow/urban unconfined category wells in $1998(1.5 \mathrm{mg} / \mathrm{L})$ was less than concentrations when shallow/urban unconfined category wells were resampled in $2006(1.9 \mathrm{mg} / \mathrm{L})$ and statistically different on the basis of Mann-Whitney U testing. These differences, however, might result from differences in aquifer flow conditions; aquifer flow conditions were higher in 1998 compared to 2006. $\mathrm{NO}_{3}$ concentrations in the Barton Springs segment of the aquifer have been previously demonstrated to be affected by variable hydrologic conditions, with lower $\mathrm{NO}_{3}$ concentrations associated with higher aquifer flow conditions (Mahler and others, 2006; Mahler and Garner, 2009). Results for shallow/ urban unconfined groundwater samples from the San Antonio segment of the aquifer are consistent with this relation.

Unconfined groundwater category wells were also sampled during two different periods that represent lower-thanaverage aquifer flow conditions: exceptionally low aquifer flow conditions in 1996 (median Comal Springs discharge of $92 \mathrm{ft}^{3} / \mathrm{s}$ ) and moderately low aquifer flow conditions in 2006 (median Comal Springs discharge of $269 \mathrm{ft}^{3} / \mathrm{s}$ ). The median $\mathrm{NO}_{3}$ concentrations measured in unconfined groundwater category samples for these two periods are similar $(1.15 \mathrm{mg} / \mathrm{L}$ for 1996 and $1.12 \mathrm{mg} / \mathrm{L}$ for 2006) and not statistically different on the basis of Mann-Whitney U test results.

$\mathrm{NO}_{3}$ concentrations for Edwards aquifer NAWQA groundwater samples were statistically correlated with specific conductance values (Kendall's tau $=.28$; fig. 15 ). In the absence of other sources of salinity (for example, mixing with more saline groundwater from the Trinity aquifer or downdip saline zone), specific conductance values would be expected to generally increases along aquifer flow paths as a result of progressive mineral-solution reactions. $\mathrm{NO}_{3}$ concentrations for NAWQA groundwater samples increase from relatively low values (median $=1.09 \mathrm{mg} / \mathrm{L}$ ) in the unconfined (recharge zone) part of the aquifer to higher values (median $=$ $1.84 \mathrm{mg} / \mathrm{L}$ ) in the confined part of the aquifer. This relation is consistent with the hypothesis that ambient $\mathrm{NO}_{3}$ in the aquifer is diluted by incoming recharge and correspondingly that recharging surface water is not the main source of $\mathrm{NO}_{3}$ to the aquifer. Storage of $\mathrm{NO}_{3}$ in soils with slow release to groundwater by diffuse infiltration is the likely source of ambient aquifer $\mathrm{NO}_{3}$ to the confined groundwater (Peterson and others, 2002). Specific conductance values (median $=578 \mu \mathrm{S} / \mathrm{cm}$ ), as well as $\mathrm{NO}_{3}$ concentrations (median $=1.85 \mathrm{mg} / \mathrm{L}$ ), are higher in shallow/urban unconfined groundwater samples relative to both unconfined and confined groundwater samples. These results indicate that urban land use affects water quality and that urban recharge is a potential source of $\mathrm{NO}_{3}$, as well as other dissolved constituents and anthropogenic contaminants, to groundwater.

\section{Historical Nitrate and Chloride Concentrations at Comal Springs}

A relatively long time series of $\mathrm{NO}_{3}$ concentration data is available for Comal Springs (1938-2006) that indicates a multidecadal upward trend for $\mathrm{NO}_{3}$ concentration (Kendall's tau $=.38$ ) (fig. 16A). These data are a compilation of analyses of filtered and unfiltered samples; analyses of unfiltered samples 


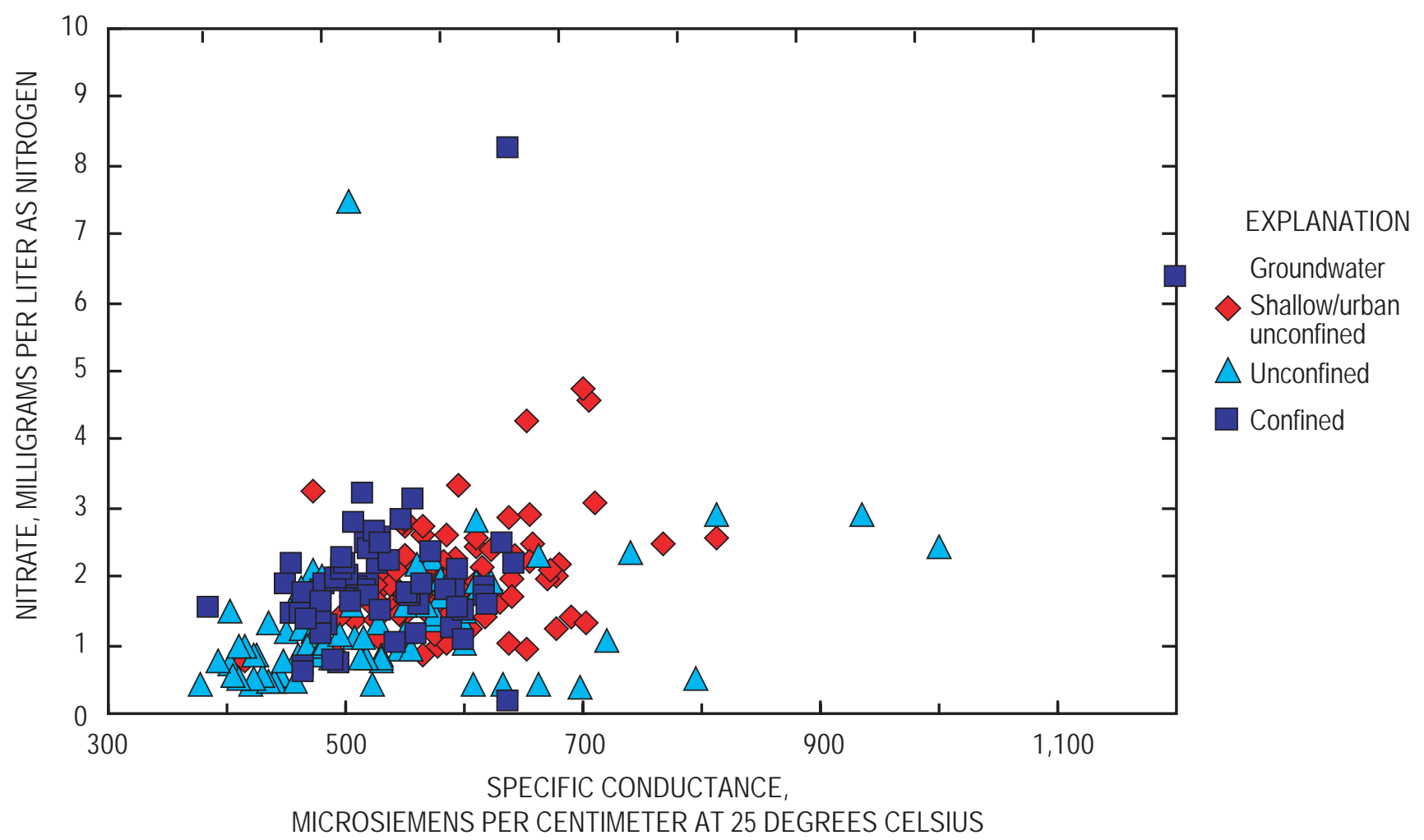

Figure 15. Relation between nitrate concentration and specific conductance for groundwater samples collected from shallow/urban unconfined, unconfined, and confined parts of the San Antonio segment of the Edwards aquifer, south-central Texas, 1996-2006.

might be affected by $\mathrm{NO}_{3}$ associated with particulate matter. Considering only results for filtered samples, the median $\mathrm{NO}_{3}$ concentration at Comal Springs during 1938-45 was $1.2 \mathrm{mg} / \mathrm{L}$ $(\mathrm{n}=6)$; the median $\mathrm{NO}_{3}$ concentration during 1993-2003 was $1.9 \mathrm{mg} / \mathrm{L}(\mathrm{n}=4)$, which is similar to the median value for NAWQA regional groundwater samples (1996-2006). The data for the two time periods are statistically different on the basis of Mann-Whitney U test results. Samples for these two time periods (1938-45 and 1993-2003) were collected during similar aquifer flow conditions as indicated by discharge at Comal Springs; median discharge was $335 \mathrm{ft}^{3} / \mathrm{s}$ during $1938-45$ and $316 \mathrm{ft}^{3} / \mathrm{s}$ during 1993-2003. Although analytical methods for these data are not available for comparison, these results suggest that matrix $\mathrm{NO}_{3}$ concentrations in the aquifer have increased over the last 70 years. Considering the large volume of water in storage in the aquifer, a $0.7-\mathrm{mg} / \mathrm{L}$ increase in median $\mathrm{NO}_{3}$ concentration at Comal Springs represents a large increase in $\mathrm{NO}_{3}$ load in the aquifer. Historical $\mathrm{NO}_{3}$ concentrations indicate no relation with discharge at Comal Springs (fig. 16B). Background $\mathrm{NO}_{3}$ concentration (that is, not anthropogenically influenced) likely results from leaching of soil $\mathrm{NO}_{3}$ into the aquifer matrix. Soil $\mathrm{NO}_{3}$ can also be affected by anthropogenic activities, including spray irrigation of wastewater (currently allowed in the aquifer contributing zone but not over the recharge zone [Cary Betz, Texas Commission on Environmental Quality, written commun.,
2009]), application of lawn fertilizers, and leakage from septic and sewer systems.

Increased $\mathrm{Cl}$ concentrations might be associated with anthropogenic sources, including septic, sewage, and wastewater systems (Panno and others, 2006; Kostick and others, 2007). Similar to $\mathrm{NO}_{3}$, the $\mathrm{Cl}$ concentration during 1938-2006 at Comal Springs increased (Kendall's tau $=.41$ ) (fig. 17). The increases in $\mathrm{NO}_{3}$ and $\mathrm{Cl}$ concentrations over time are consistent with increases in anthropogenic effects on aquifer geochemistry associated with ongoing urbanization over the last 70 years.

\section{Selected Anthropogenic Organic Contaminants: Occurrence and Trends}

Anthropogenic organic contaminants, such as pesticides and solvents, are of concern in groundwater and drinkingwater supplies because of their potential detrimental effects on the environment and to human health. Many of these compounds are relatively soluble and thus can be present in groundwater if anthropogenic sources are present. The frequency of detection and spatial distribution of anthropogenic contaminants provide insight into effects of anthropogenic activities on water quality. Previous studies have documented the detection of anthropogenic organic contaminants in the 

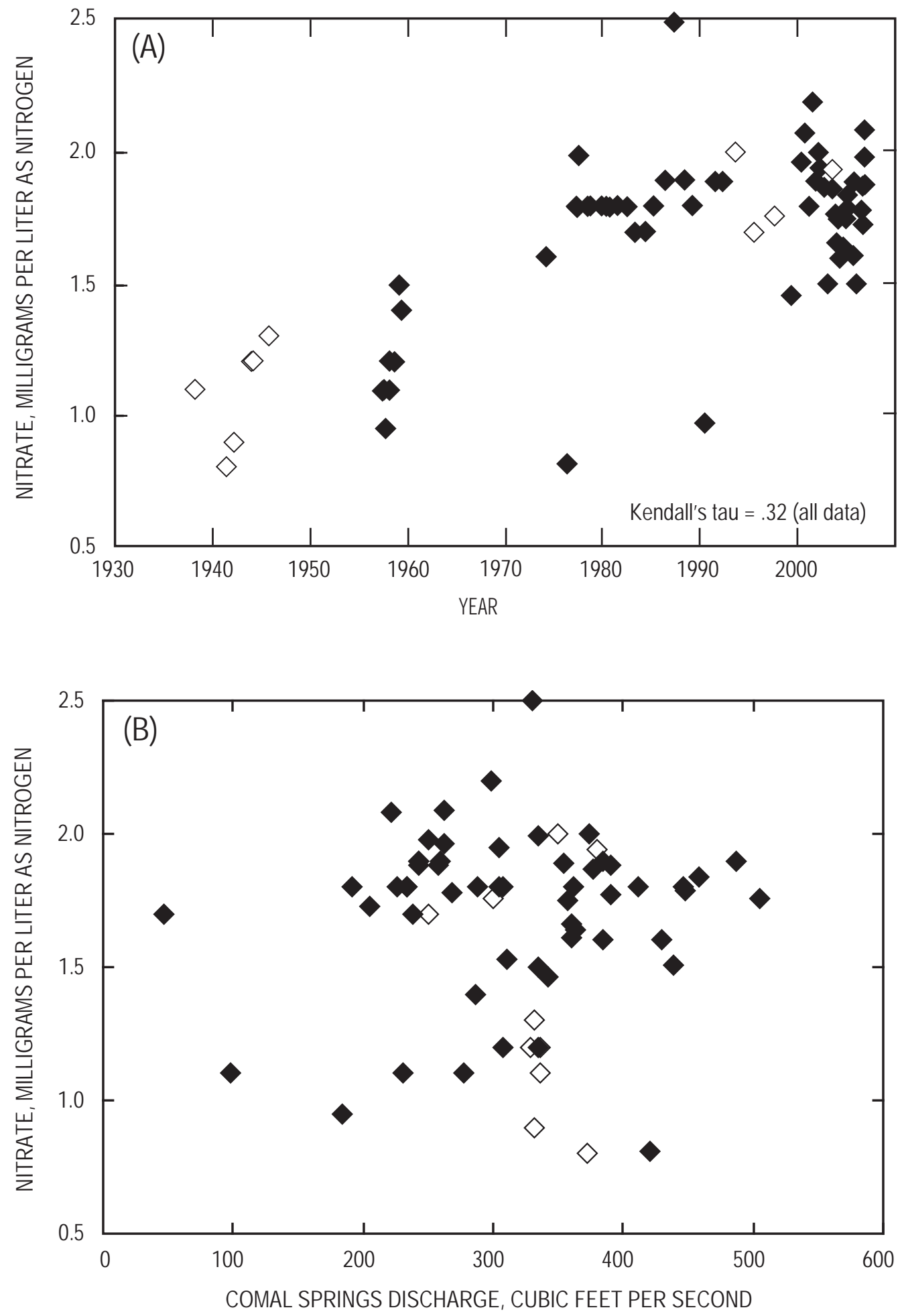

$\begin{aligned} & \text { EXPLANATION } \\ \diamond & \text { Filtered sample } \\ \diamond & \text { Unfiltered sample }\end{aligned}$

Figure 16. (A) Time series of nitrate concentration in Comal Springs discharge, and (B) relation between nitrate concentration at Comal Springs and Comal Springs discharge, San Antonio segment of the Edwards aquifer, south-central Texas, 1938-2006. 


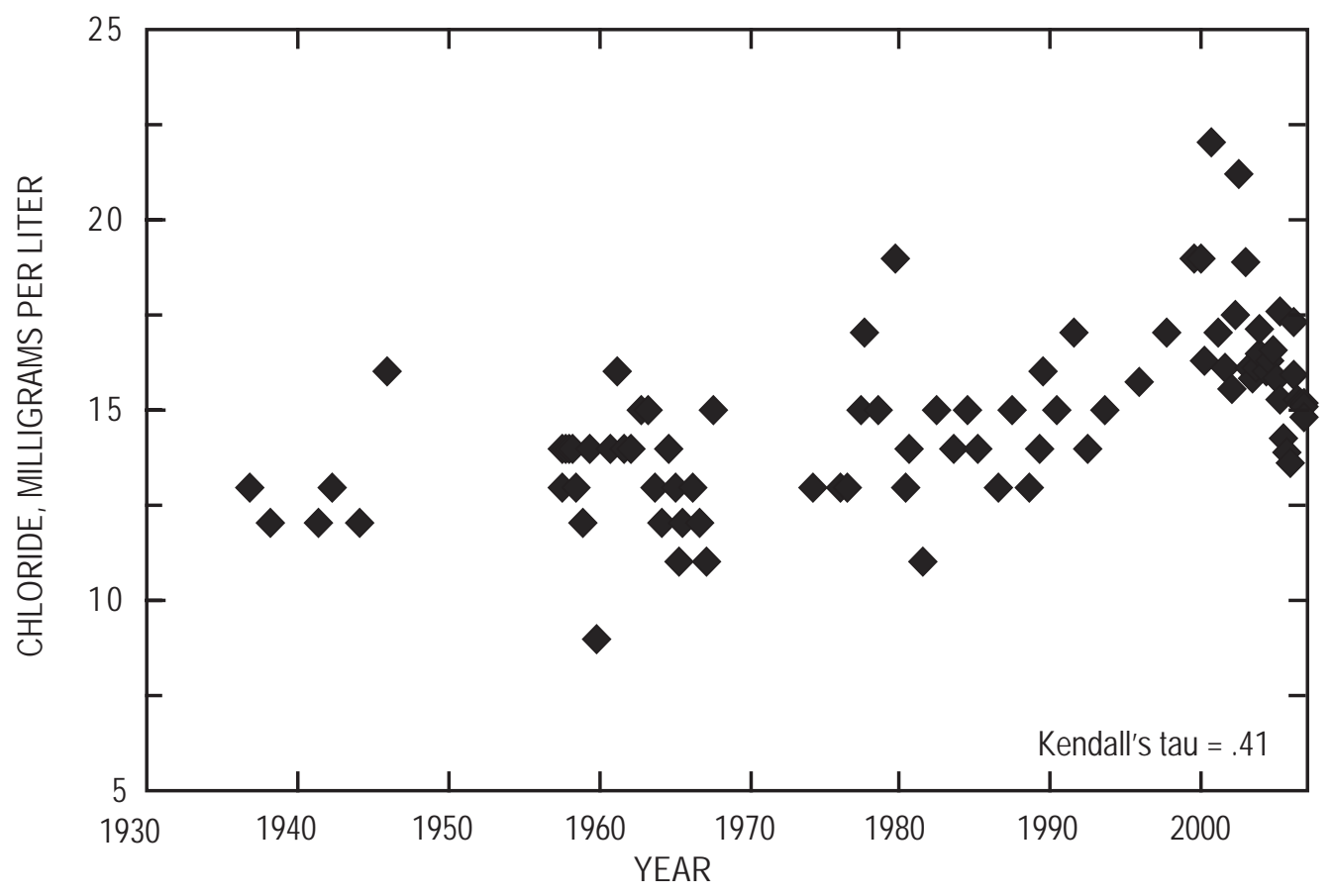

Figure 17. Time series of chloride concentration in Comal Springs discharge, San Antonio segment of the Edwards aquifer, southcentral Texas, 1938-2006.

San Antonio segment of the Edwards aquifer but have not addressed factors that influence their presence, concentration, transport, and temporal variability in response to changes in hydrologic conditions (Bush and others, 2000; Fahlquist and Ardis, 2004). The most frequently detected contaminants throughout the aquifer (atrazine, DEA, simazine, PCE, and chloroform) were most often detected in samples of shallow/ urban unconfined groundwater (all of these contaminants were detected in more than 50 percent of these samples) and were least frequently detected in samples of unconfined groundwater (fig. 18). These results indicate that samples of groundwater from the unconfined part of the aquifer are the least affected by these anthropogenic contaminants, which is consistent with the location of these sample sites in largely undeveloped rural and rangeland areas. This observation, combined with high detection frequencies in samples of shallow/ urban unconfined groundwater, indicates that the urban environment is a source of anthropogenic contaminants to Edwards aquifer groundwater.

Concentrations of the three most frequently detected pesticides (atrazine, simazine, and prometon) and the most frequently detected pesticide degradate compound (DEA, a metabolite and common environmental degradation product of atrazine [Fallon and others, 2002]) were low throughout the aquifer; median concentrations for all compounds were less than the laboratory reporting levels for samples of unconfined groundwater and greater than the reporting levels for samples of shallow/urban unconfined groundwater (fig. 18; table 4). Median concentrations of PCE and chloroform were higher than medians for pesticide degradate compounds and were highest in samples of shallow/urban unconfined groundwater (fig. 18; table 4).

Chloroform detections indicate that this constituent is well distributed throughout the Edwards aquifer relative to other frequently detected anthropogenic contaminants, with high detection frequencies in all parts of the aquifer (fig. 18). Detection of chloroform is also common in the Barton Springs segment of the Edwards aquifer, where it is detected routinely in springflow from Barton Springs, with concentrations increasing during storm events (Mahler and others, 2006). These results and the nearly ubiquitous low-level detection of chloroform throughout the aquifer, including unconfined recharge-zone wells, indicate that low concentrations of chloroform are likely stored in the aquifer matrix. Few data are available for chloroform analyses of surface waters from the recharge zone for the San Antonio segment; available concentration results for surface water were mostly less than the laboratory reporting levels. Chloroform reporting levels for surface-water analyses, however, were commonly higher than chloroform concentrations measured for groundwater analyses done as part of the NAWQA Program (U.S. Geological Survey, 2009).

Frequency of detection and concentration of chloroform in the Edwards aquifer are similar to those for studies across the United States (Bush and others, 2000). The frequent detection of chloroform in groundwater at low concentrations (less than $1 \mu \mathrm{g} / \mathrm{L}$ ) in domestic, monitoring, and public-supply wells in a wide range of land-use settings (rangeland to agriculture 

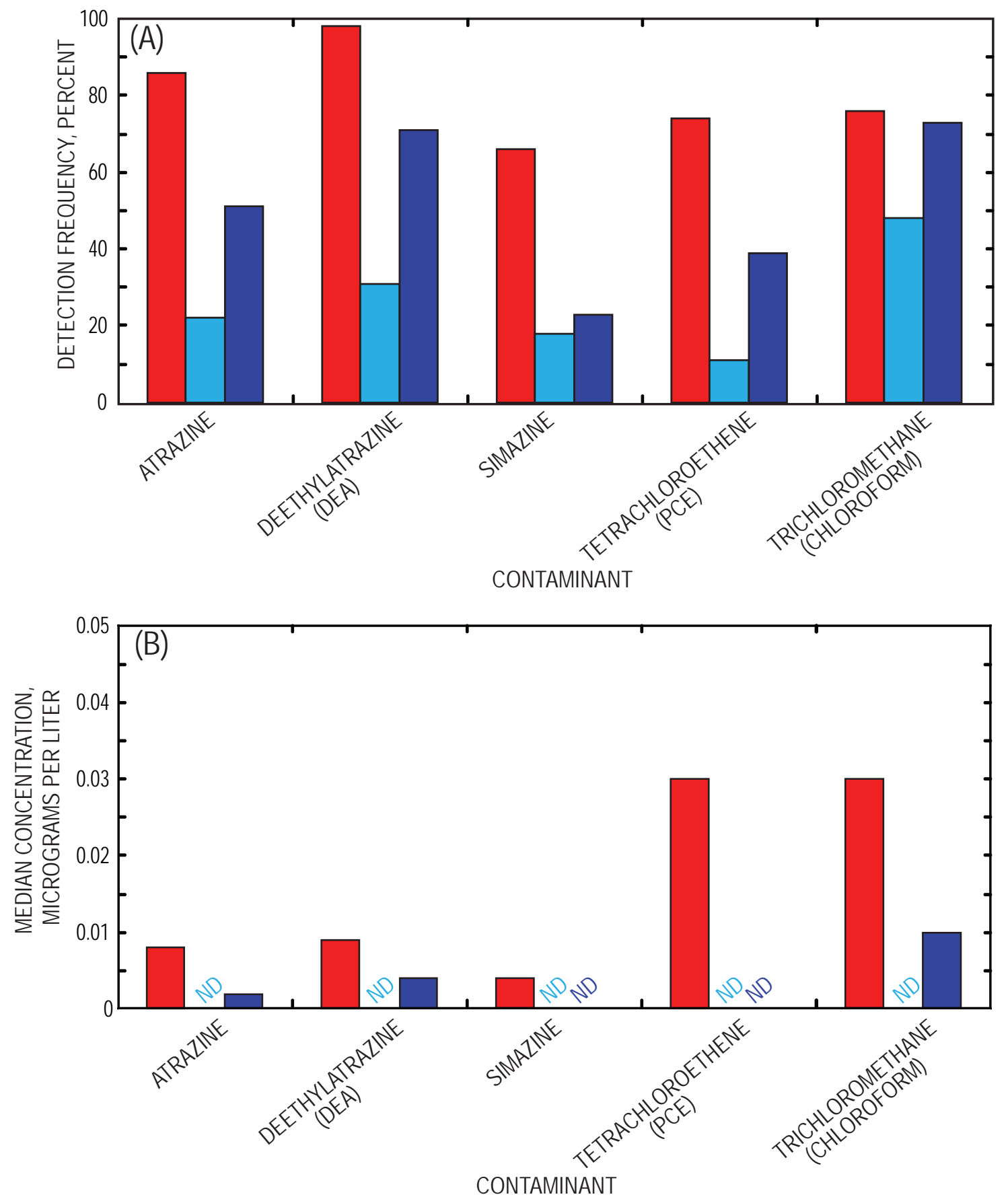

EXPLANATION

Groundwater

- Shallow/urban unconfined

$\square$ Unconfined

- Confined

ND Nondetection at laboratory reporting level

Figure 18. (A) Detection frequency and (B) median concentration of the most frequently detected anthropogenic contaminants in groundwater samples collected from shallow/urban unconfined, unconfined, and confined parts of the San Antonio segment of the Edwards aquifer, south-central Texas, 1996-2006. 
to urban) has been widely documented and is attributed, in part, to the recycling of chlorinated waters (Moran and others, 2002; Zogorski and others, 2006). Chloroform is a byproduct of drinking-water treatment processes. Sources of chloroform in domestic wells include shock chlorination and leakage from septic areas. Potential sources in shallow/urban unconfined monitoring wells include leaking water and wastewater lines, septic systems, and recharge from irrigation with treated water. Public water-supply sources also include the possible use of treated water as a downhole lubricant of well pumps. In addition to anthropogenic sources, chloroform has some natural sources, including production in soils and emission from seawater (Hoekstra and others, 1998; McCulloch, 2003). Biomass burning is another potential source of chloroform to the atmosphere (Rudolph and others, 1995; Rudolph and others, 2000; Simpson and others, 2007).

An assessment of temporal variability, trends, and associations for anthropogenic contaminants throughout the study period (1996-2006) provides insight into the effects of urbanization on the Edwards aquifer. Frequently detected anthropogenic contaminants (atrazine, DEA, simazine, chloroform, and PCE) often are detected together, but concentrations are not well correlated with major ions, nutrients, isotopes, or physicochemical properties. Shallow/ urban unconfined groundwater sites were sampled in both 1998 (high aquifer flow conditions) and 2006 (moderately low aquifer flow conditions). About twice as many contaminants were detected for shallow/urban unconfined sample sites during 1998 under high aquifer flow conditions (median discharge at Comal Springs of $429 \mathrm{ft}^{3} / \mathrm{s}$ ), relative to 2006 (median discharge at Comal Springs of $247 \mathrm{ft}^{3} / \mathrm{s}$ ). These results indicate that recharge water derived from urban areas might be a source for a number of anthropogenic contaminants to Edwards aquifer groundwater. The most frequently detected anthropogenic contaminants were in the majority of samples from the shallow/urban unconfined part of the aquifer for both the 1998 and 2006 sampling periods, with small differences in detection frequency and median detected concentrations for each constituent (except chloroform, which had a higher median concentration in 2006) (fig. 19). On the basis of these results, the most frequently detected anthropogenic contaminants appear to have been persistent in the shallow/ urban unconfined part of the aquifer during the study period (1996-2006).

Unconfined groundwater samples were collected in 1996 during exceptionally low aquifer flow conditions (median Comal Springs discharge of $92 \mathrm{ft}^{3} / \mathrm{s}$ ) and in 2006 during moderately low aquifer flow conditions (median Comal Springs discharge of $269 \mathrm{ft}^{3} / \mathrm{s}$ ). For these samples, the frequency of detection for all frequently detected compounds was higher in 2006 and at least two times higher for all compounds except chloroform (fig. 19). Median concentrations for frequently detected compounds were mostly less than the laboratory reporting levels, except for chloroform for samples collected in 2006 (fig. 19). The observed increase in detection frequency between 1996 and 2006 might partly result from increased urbanization in the region in 2006 compared to 1996 , particularly over the unconfined part of the aquifer (Friesen and others, 2004). Differences in the detection frequency of anthropogenic contaminants might also result from variations in hydrologic conditions, as discussed further in the section "Relation Between Geochemistry and Hydrologic Conditions."

\section{Relation Between Geochemistry and Hydrologic Conditions}

A comparison of temporal variations in hydrologic conditions, as represented by variations in the amount of recharge, water-level altitudes in indicator wells, and springflow at major discharge points, along with time-series data for groundwater geochemistry, provide insight into time scales and controls on water-quality changes, fluid evolution processes, contaminant transport and storage, and temporal effects of anthropogenic contaminants on water quality. Five of the shallow/urban unconfined category wells sampled by NAWQA had a higher frequency of sampling than other sites (fig. 20), with a total of eight samples collected at each well during the 10-year study. Relatively continuous or frequent periodic water-level altitude measurements for these five wells allow for comparison between geochemical variability and hydrologic conditions at each site. Water-level altitudes for these five wells (fig. 21A) vary in a consistent manner in direct response to rainfall (fig. 21B). Water-level altitude fluctuations for the five wells also are consistent with variations in regional hydrologic conditions, evidenced by discharge at Comal Springs (fig. 21C) and water-level altitudes in the confined Bexar County index well (J-17; fig. 3). The rapid response to changes in hydrologic conditions observed in these wells appears to be typical of the shallow unconfined part of the aquifer based on similar results for water-level variations at other monitored shallow/urban unconfined groundwater wells.

Temporal variability observed in the five shallow/urban unconfined category wells allows for inferences regarding controls on water-quality variations and sources of anthropogenic contaminants. The sampling frequency for these wells was not based on water-level fluctuations and thus does not encompass the complete range of aquifer flow conditions over the study period. Nonetheless, samples were collected over a large range of aquifer flow conditions, including high, moderate, and low. The following discussion focuses on three constituents or ratios of constituents that are representative of water-quality concerns and geochemical processes: (1) nitrate $\left(\mathrm{NO}_{3}\right)$, an important nutrient, that in high concentrations might be indicative of anthropogenic sources and is a detriment to water quality, (2) atrazine, a commonly used pesticide and frequently detected anthropogenic contaminant in the Nation's groundwater (Gilliom and others, 2006); and (3) the magnesium to calcium molar ratio $(\mathrm{Mg} / \mathrm{Ca})$, an indicator of waterrock interaction and residence time. 

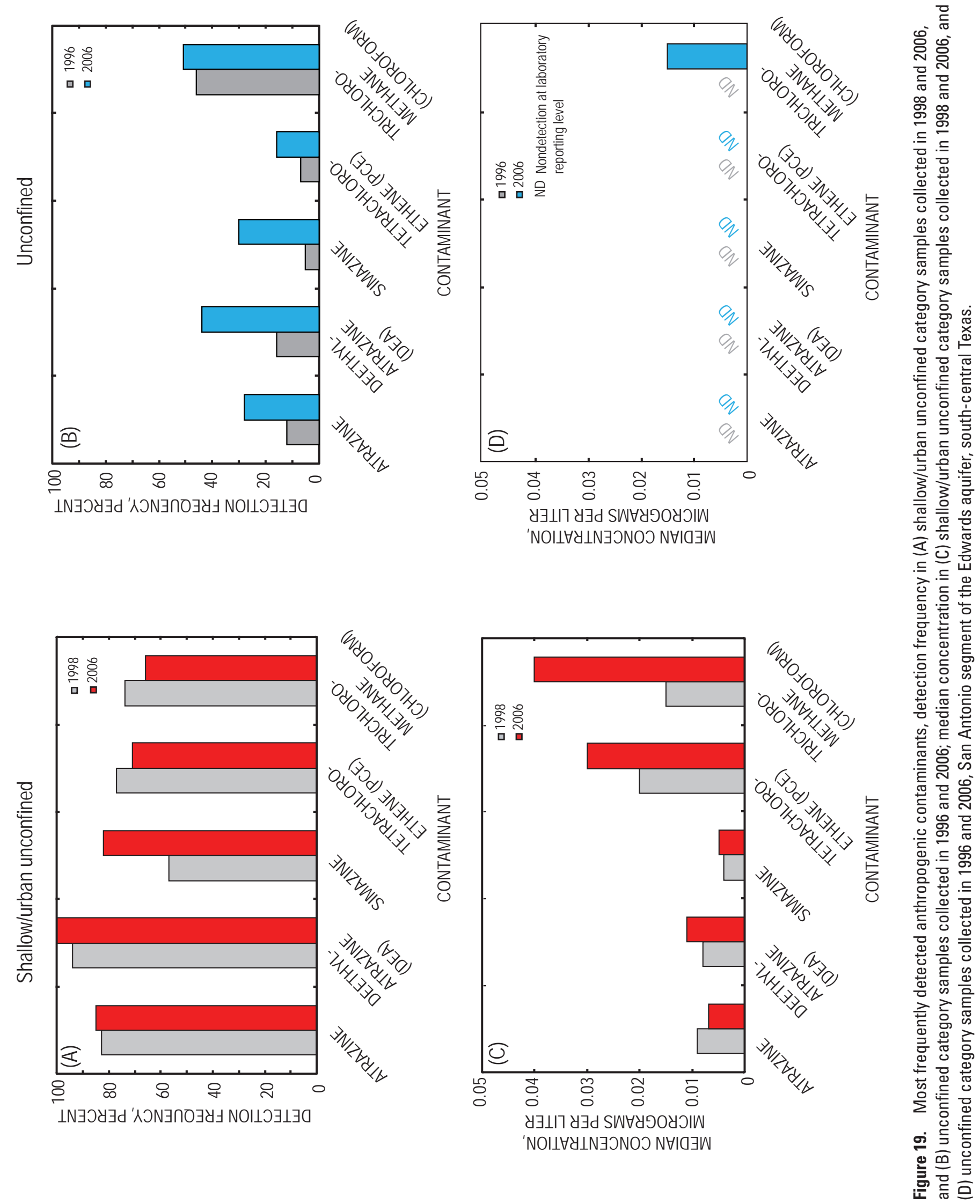


\section{Temporal Variability in Geochemical Constituents}

A comparison of temporal variability in $\mathrm{NO}_{3}$ and atrazine concentrations and $\mathrm{Mg} / \mathrm{Ca}$ ratios measured in samples collected from the five shallow/urban unconfined groundwater wells (fig. 22) indicates there were differences in the response of the five wells to changes in hydrologic conditions, as well as differences between the responses of the considered geochemical constituents. Time-series data for $\mathrm{NO}_{3}$ indicate that concentrations are less variable than atrazine concentrations and also are less consistent among the five wells (fig. 22A). Time-series data for atrazine show some consistencies from well to well; atrazine concentrations are variable in time and show similar patterns of increase and decrease (fig. 22B). For example, concentrations are higher at four of the five wells in late 2004 relative to lower concentrations at most of the wells in mid-1999, late 2002, and late 2006. This consistency suggests that some of the observed geochemical variability has a common control and might reflect processes affecting all five wells. There are, however, differences between the five wells, with some showing relatively stable geochemistry and little variability in geochemical constituents (for example, AY-68-28-517) and others showing larger changes in geochemical constituents (for example, AY-68-29-216). Similar to $\mathrm{NO}_{3}$ concentrations, temporal variations in $\mathrm{Mg} / \mathrm{Ca}$ ratios at these five wells show small ranges in variability, except for well AY-68-28-211, and less consistency among the five wells (fig. 22C). The well with the greatest variability in both $\mathrm{NO}_{3}$ and atrazine concentrations and the lowest $\mathrm{Mg} / \mathrm{Ca}$ ratios was well AY-68-28-314, which also had the most variability in water-level altitudes (fig. 21A); these results indicate that well AY-68-28-314 was the most responsive of the group to fluctuating hydrologic conditions. Measurement of elevated atrazine concentration at this well in 2005 (fig. 22B), for example, coincides with high water-level altitude in the well (fig. 21A).

Using the variability in Comal Springs discharge to represent changes in regional hydrologic conditions, the relation between the geochemical variability for these five wells and changes in regional hydrologic conditions was assessed (fig. 23). $\mathrm{NO}_{3}$ concentration (considering all data for the five wells) is not significantly correlated (fig. 23A) with Comal Springs discharge. Atrazine concentration (considering all data for the five wells), is positively correlated (fig. 23B) with Comal Springs discharge (Kendall's tau $=.29$ ), indicating that atrazine concentration in samples of shallow/urban unconfined groundwater tends to be higher during wetter hydrologic conditions. $\mathrm{Mg} / \mathrm{Ca}$ ratio is not significantly correlated (fig. 23C) with Comal Springs discharge. Data for well AY-68-28-314 (the well with the greatest variability in geochemical constituents) had a significant positive correlation between atrazine concentration and Comal Springs discharge (Kendall's tau $=.78$ ) and significant negative correlations between $\mathrm{NO}_{3}$ concentration and Comal Springs discharge and $\mathrm{Mg} / \mathrm{Ca}$ ratio and Comal Springs discharge (Kendall's tau $=-.57$ and -.71 , respectively). Data for the four other wells did not have significant correlations between $\mathrm{NO}_{3}$ concentrations, atrazine concentrations, or $\mathrm{Mg} / \mathrm{Ca}$ ratios and Comal Springs discharge. This lack of statistical correlation might partly reflect complex hydrogeology and hysteresis effects (for example, a delay between the hydrologic forcing and the geochemical response). A comparison of water-level altitude data for these five wells with geochemical constituents (considering all data for the five wells), indicates a significant correlation between atrazine concentration and water-level altitude (Kendall's tau $=.39$ ), as well as between the $\mathrm{Mg} / \mathrm{Ca}$ ratio and water-level altitude (Kendall's tau $=.23$ ).

A comparison of variations in $\mathrm{NO}_{3}$ and atrazine concentrations and $\mathrm{Mg} / \mathrm{Ca}$ ratios with respect to water-level altitudes for the most responsive of the five shallow/urban unconfined wells (well AY-68-28-314) demonstrates distinct changes in geochemical constituents in response to changes in hydrologic conditions and provides insight into processes affecting variable water quality and sources and transport of dissolved constituents through the aquifer. Higher $\mathrm{NO}_{3}$ concentrations at this well correspond to low water-level altitudes during drier hydrologic conditions (fig. 24A) (Kendall's tau $=.64$ ). Higher atrazine concentrations correspond to peaks in waterlevel altitude during wetter hydrologic conditions (fig. 24B) (Kendall's tau $=.68$ ). Higher $\mathrm{Mg} / \mathrm{Ca}$ ratios correspond to lower water-level altitudes during drier hydrologic conditions (fig. 24C) (Kendall's tau $=-.78$ ). The remaining four wells (AY-68-28-211, AY-68-28-517, AY-68-27-612, and AY-68-29-216) with time-series data show some significant correlations between water-level altitude data and geochemical constituents $\left(\mathrm{NO}_{3}\right.$ and atrazine concentrations and $\mathrm{Mg} / \mathrm{Ca}$ ratios), but results are not consistent. That is, not all of the remaining four wells show significant correlations between water-level altitude data and any specific geochemical constituent, and no specific geochemical constituent shows a significant correlation with water-level altitude data for all or most of the four remaining wells. Sampling sites such as well AY-68-28-314, with a more direct relation between hydrologic conditions and geochemistry likely reflect a greater component of conduit-dominated flow relative to sites with less variable (responsive) geochemistry and likely more complex hydrogeology. Sampling sites such as well AY-68-28-314 are well suited for long-term monitoring to assess the relation between aquifer geochemistry and hydrologic conditions.

Previous work in the Barton Springs segment of the aquifer has addressed links between variability in $\mathrm{NO}_{3}$ and atrazine concentrations and hydrologic conditions using a higher resolution geochemical dataset (Mahler and others, 2006) and provides a useful analog for evaluating the variability of these constituents in the San Antonio segment, especially given the smaller dataset available to assess temporal variability in the San Antonio segment. $\mathrm{NO}_{3}$ variability in the Barton Springs segment of the aquifer was characterized by background $\mathrm{NO}_{3}$ concentrations that are diluted by incoming recharge with lower $\mathrm{NO}_{3}$ concentrations during high aquifer flow conditions (Mahler and others, 2006; Mahler and Garner, 2009). Mahler and others (2006) also documented increases 

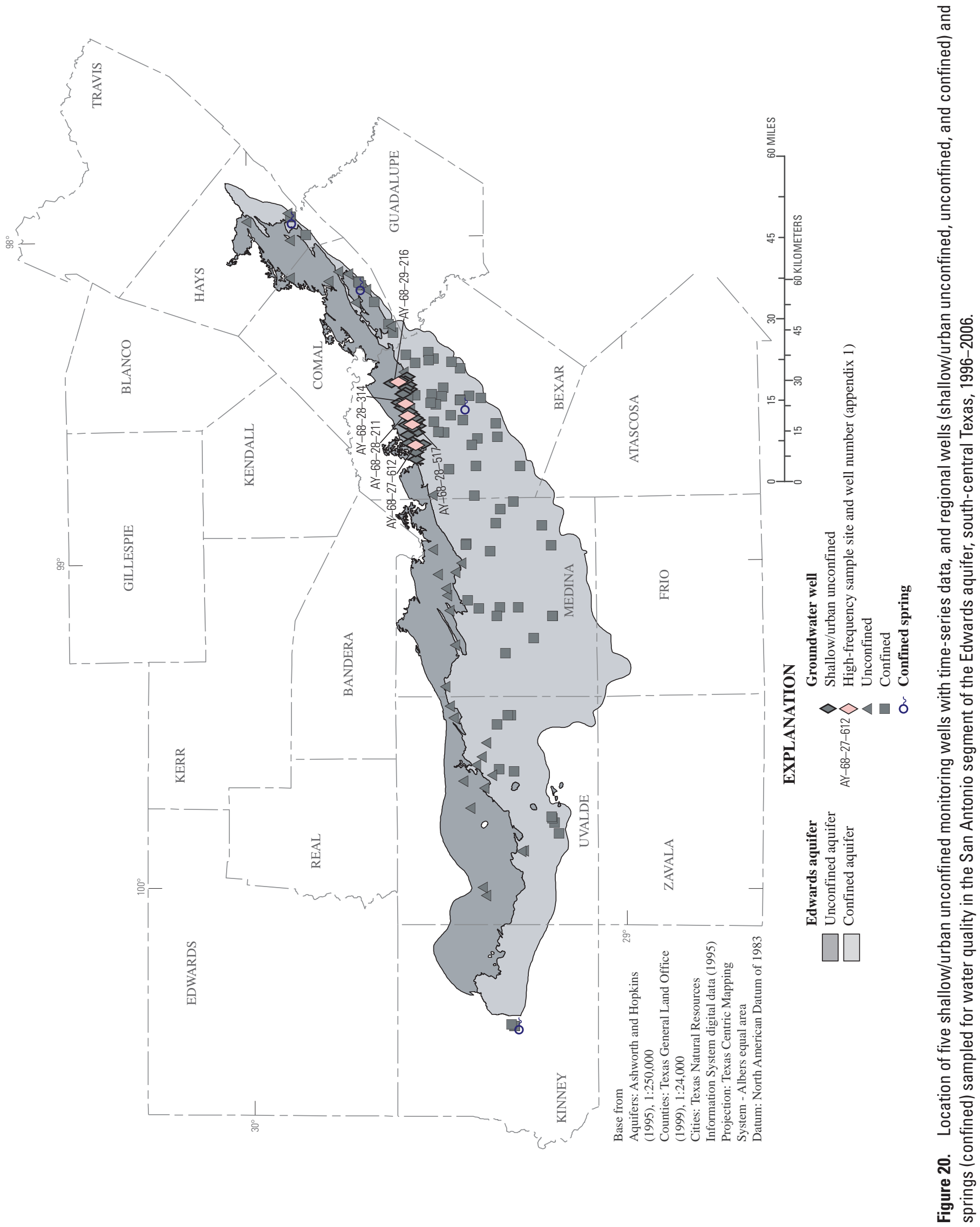


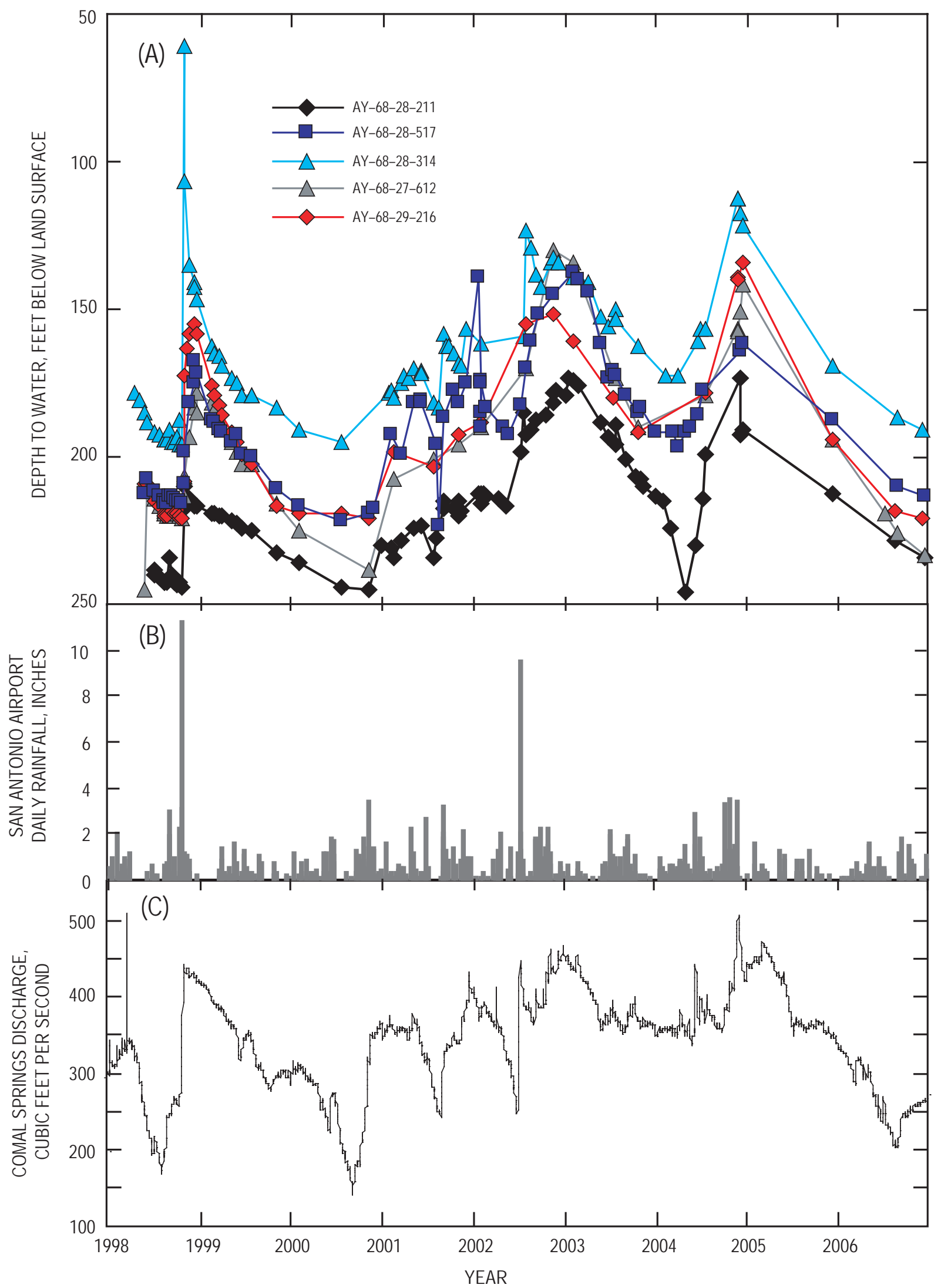

Figure 21. Time-series comparison of $(A)$ depth to water in five shallow/urban unconfined category monitoring wells; (B) daily rainfall at San Antonio International Airport, and (C) discharge at Comal Springs, San Antonio segment of the Edwards aquifer, south-central Texas, 1998-2006. 


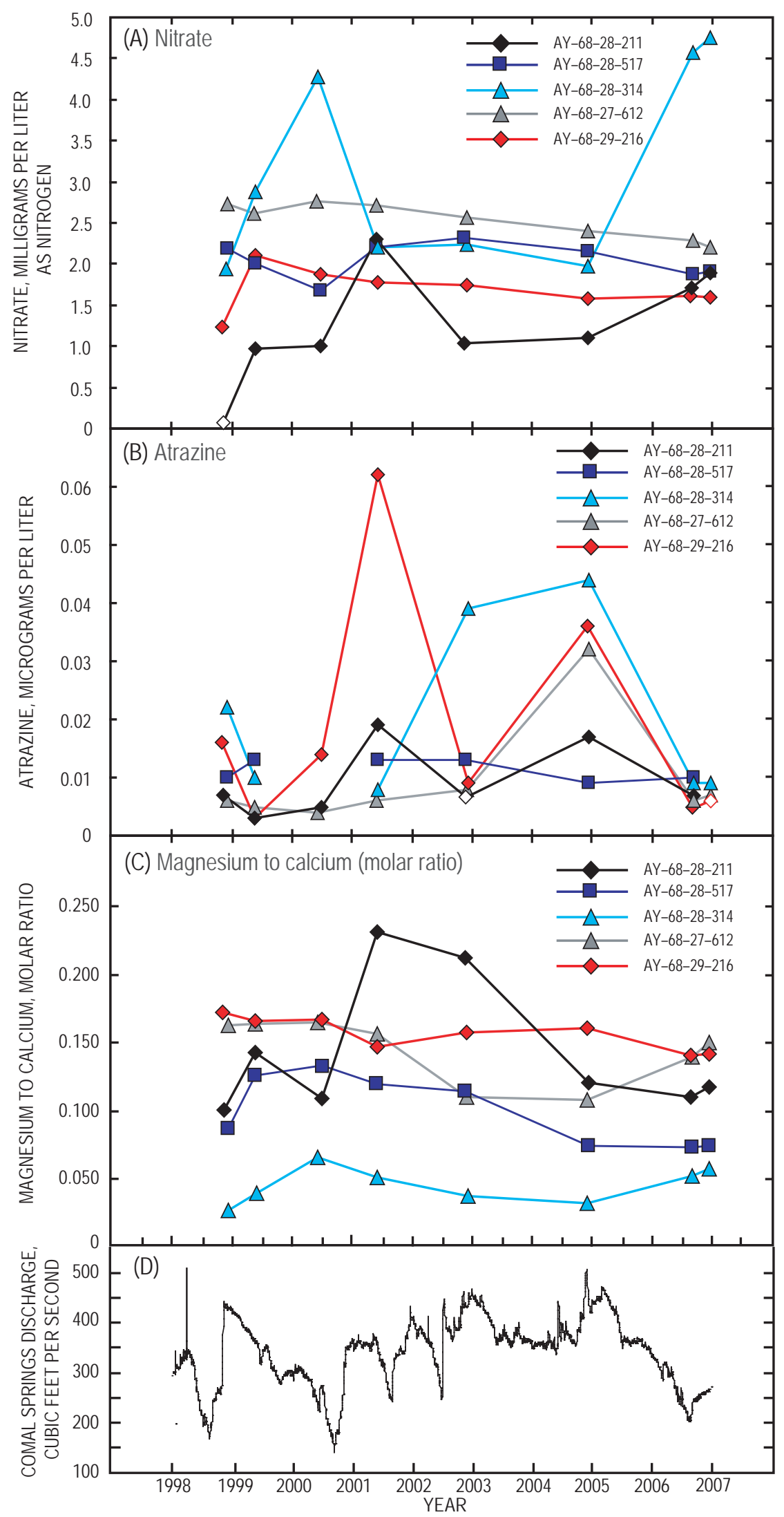

Figure 22. Time series comparison of $(A)$ nitrate concentration, $(B)$ atrazine concentration, $(C)$ magnesium to calcium (molar ratio) for five shallow/urban unconfined category monitoring wells, and (D) discharge at Comal Springs, San Antonio segment of the Edwards aquifer, south-central Texas, 1998-2006. (Nondetections at laboratory reporting level shown as open symbols.) 


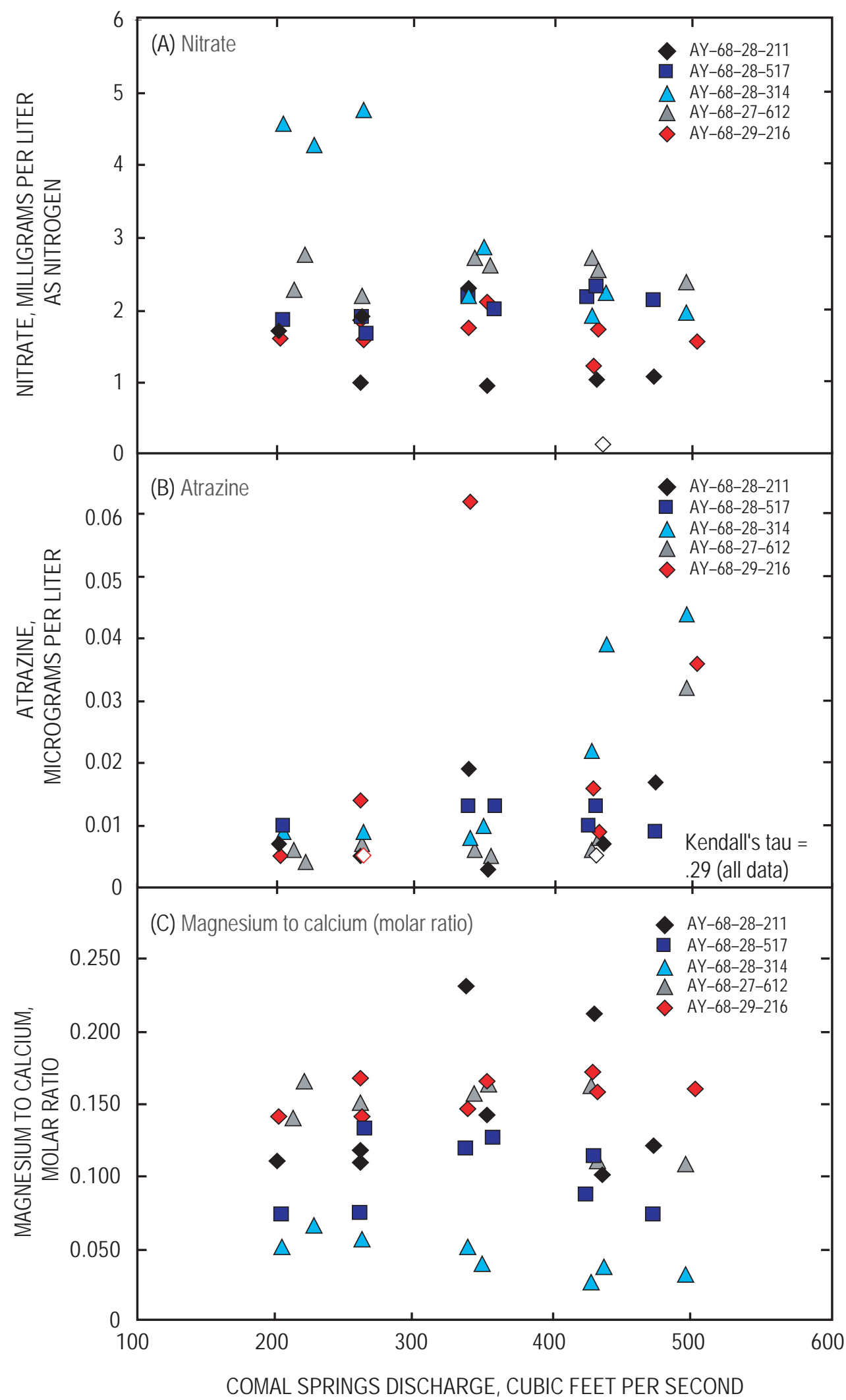

Figure 23. Relation between Comal Springs discharge and (A) nitrate concentration, (B) atrazine concentration, and (C) magnesium to calcium (molar ratio) for five shallow/urban unconfined category monitoring wells, San Antonio segment of the Edwards aquifer, southcentral Texas, 1998-2006. (Nondetections at laboratory reporting level shown as open symbols.) 


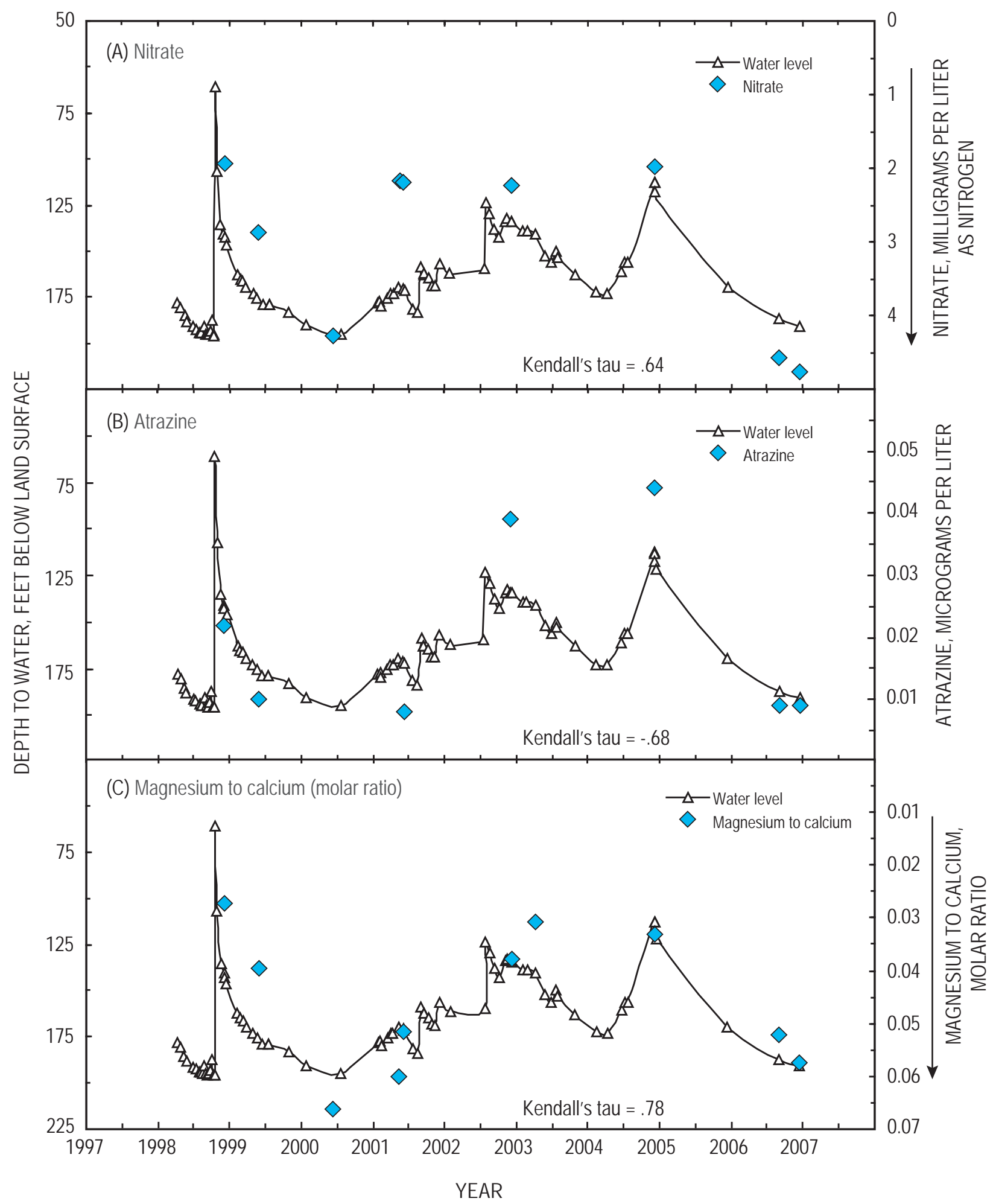

Figure 24. Time-series comparison of depth to water and $(A)$ nitrate concentration, $(B)$ atrazine concentration, and $(C)$ magnesium to calcium (molar ratio) for shallow/urban unconfined category monitoring well AY-28-28-314, San Antonio segment of the Edwards aquifer, south-central Texas, 1998-2006. Note inverse scale for nitrate concentration and magnesium to calcium (molar ratio) in (A) and (C). 
in atrazine in groundwater associated with high aquifer flow conditions as a result of recharging surface water with elevated atrazine concentrations. $\mathrm{NO}_{3}$ and atrazine variability at site AY-68-28-314 (fig. 24A,B) is consistent with observed relations between these constituents and hydrologic conditions in the Barton Springs segment of the aquifer.

Mahler and others (2006) proposed that during low aquifer flow conditions (characterized by low amounts of recharge, low amounts of discharge, and low water-level altitudes in wells), focused recharge and associated contaminants move rapidly though the conduit system of the Barton Springs segment of the Edwards aquifer and subsequently discharge at Barton Springs. During high aquifer flow conditions, when conduits are already saturated with water, focused recharge is diluted by water in the conduits and much of the recharge and associated contaminants go into matrix storage. In this conceptual model, contaminants are slowly released from the matrix under low-flow conditions, increasing background (low-flow) concentrations over the long term (Mahler and Massei, 2007). This process of matrix release of accumulated low concentrations of anthropogenic contaminants might account for the persistency of some anthropogenic contaminant detections in confined wells in the San Antonio segment. Those contaminants most frequently detected in both the Barton Springs segment and the San Antonio segment of the Edwards aquifer are similar, which points to regional-scale urbanization and contaminant sources. The most frequently detected anthropogenic contaminants in the Edwards aquifer are similar to those detected in aquifers across the Nation (Gilliom and others, 2006; Zogorski and others, 2006).

Analysis of available surface-water data from major recharging streams in the contributing and recharge zones of the Edwards aquifer during the same time period as groundwater sampling (fig. 5, table 2) for commonly occurring anthropogenic contaminants indicates that many of the same compounds are detected frequently in both surface water and groundwater. Few NAWQA (or other) surface-water sample sites have been routinely sampled for anthropogenic and organic contaminants; available data are mostly limited to pesticides with few analyses for VOCs. Atrazine, DEA, and simazine were detected in 75 percent, 48 percent, and 31 percent, respectively, of NAWQA surface-water samples analyzed $(n=48)$. Chloroform and PCE were not detected in surface-water samples but were analyzed in only 11 samples collected at the considered sites (fig. 5, table 2) during 1996-2007. Concentrations of atrazine were about one order of magnitude higher in surface-water samples (median $=0.015$ $\mu \mathrm{g} / \mathrm{L} ; \mathrm{n}=48$ ) compared to groundwater samples (median $=$ $0.003 \mu \mathrm{g} / \mathrm{L}$ ). Detected concentrations of DEA and simazine in surface-water samples tended to be higher than in groundwater samples, although median values in surface-water samples are less than laboratory reporting levels for these compounds, which limits a direct comparison of concentrations. These results are consistent with the hypothesis that some frequently detected anthropogenic contaminants, such as atrazine, enter the groundwater with recharging surface water.
A specific source, or sources, of atrazine to recharging surface water in the study area is not known; the most direct source, application of atrazine in the recharge zone, is not well documented. The recharge zone is predominantly rural with land use characterized by rangeland and forest (fig. 4). Atrazine is used in agricultural and urban applications. As a result, the application of atrazine might be higher in agricultural land-use areas (which are largely over the confined part of the aquifer) or urban land-use areas. Atrazine might also be transported through the atmosphere by wind. Atrazine has been routinely detected where analyzed in rainwater samples collected from across the United States and from agricultural land-use areas (Majewski and Capel, 1995); however, no rainwater samples from central Texas have been analyzed for pesticides through the NAWQA Program.

$\mathrm{Mg} / \mathrm{Ca}$ ratios for the five shallow/urban unconfined wells that were sampled at a higher frequency had a median value of 0.12 , which is lower than results for samples of unconfined and confined groundwater categories (fig. 7; table 3). Lower $\mathrm{Mg} / \mathrm{Ca}$ ratios likely reflect less geochemically evolved water, shorter groundwater residence times, and (or) mixing of groundwater with dilute, recent recharge. Geochemical evolution processes and mixing with recent recharge might proceed over short time scales in response to hydrologic variability, as demonstrated by higher $\mathrm{Mg} / \mathrm{Ca}$ ratios associated with lower water-level altitudes for well AY-68-28-314 (fig. 24C). This relation is consistent with drier hydrologic conditions and correspondingly longer fluid residence times allowing for relatively greater amounts of water-rock interaction.

The time series of variability in $\mathrm{NO}_{3}$ concentration at well AY-68-28-314 indicates that ambient groundwater $\mathrm{NO}_{3}$ is diluted by recharge water, a process that is consistent with observed variability in $\mathrm{NO}_{3}$ concentrations in the Barton Springs segment of the aquifer (Mahler and others, 2006; Mahler and Garner, 2009). The median $\mathrm{NO}_{3}$ concentration for surface-water streams (fig. 5, table 2) in and near the recharge zone for the San Antonio segment during the study period is $0.36 \mathrm{mg} / \mathrm{L}(\mathrm{n}=275$, range $=0.03$ to $1.9 \mathrm{mg} / \mathrm{L})$. This is significantly less (on the basis of Mann-Whitney $U$ test results) than the median Edwards aquifer groundwater $\mathrm{NO}_{3}$ concentration of $1.7 \mathrm{mg} / \mathrm{L}$ and is consistent with the hypothesis that, in the absence of other distinct $\mathrm{NO}_{3}$ sources, recharging surface water will dilute ambient groundwater $\mathrm{NO}_{3}$ concentrations. A range of natural and anthropogenic sources likely contribute to ambient groundwater $\mathrm{NO}_{3}$ concentrations. For example, $\mathrm{NO}_{3}$ concentrations measured at well AY-68-28-314 were consistently higher relative to $\mathrm{NO}_{3}$ concentrations measured in other shallow/urban unconfined wells (appendix 4). The median $\mathrm{NO}_{3}$ concentration at well AY-68-28-314 was $2.6 \mathrm{mg} / \mathrm{L}$, compared to a median of $1.9 \mathrm{mg} / \mathrm{L}$ for all shallow/ urban unconfined groundwater samples (significantly different on the basis of Mann-Whitney $\mathrm{U}$ test results). The median $\mathrm{NO}_{3}$ concentration at site AY-68-28-314 during drier hydrologic conditions, when the water-level altitude was low, is as high as $4.8 \mathrm{mg} / \mathrm{L}$. These results indicate that groundwater samples from this well were affected by a local source of $\mathrm{NO}_{3}$. 


\section{Historical Major/Trace Element Ratios}

Major ion data extending back several decades (19572006) are available for some groundwater monitoring wells (13) in the Edwards aquifer that were sampled by the NAWQA Program (fig. 25; table 5, at end of report). Sufficient major ion data are available for these wells to assess temporal variability in $\mathrm{Mg} / \mathrm{Ca}$ ratios. Eleven of the 13 wells are completed in the confined part of the aquifer and are located across the region, from Uvalde County in the western part of the study area to Comal County in the northeastern part of the study area. The remaining two wells are completed in the unconfined part of the aquifer in Bexar County. Median $\mathrm{Mg} / \mathrm{Ca}$ ratios were smaller and variability (interquartile range) in $\mathrm{Mg} / \mathrm{Ca}$ ratios was larger in samples collected from the two unconfined wells relative to median ratios and variability in samples collected from most of the confined wells (table 5). Historical $\mathrm{Mg} / \mathrm{Ca}$ ratios for samples collected from the 11 confined wells (range of 0.08 to 0.51 with a median value of 0.27 ) are similar to $\mathrm{Mg} / \mathrm{Ca}$ ratios for samples collected from NAWQA confined aquifer category sites during 1996-2006 (range of 0.09 to 0.79 with a median value of 0.35 ). Historical $\mathrm{Mg} / \mathrm{Ca}$ ratios for samples collected from the 11 confined wells varied widely among the wells (interquartile range of 0.035 to 0.101 ) (table 5). There is no apparent relation between $\mathrm{Mg} / \mathrm{Ca}$ ratios and the geographic location of these confined wells across the aquifer. For example, high $\mathrm{Mg} / \mathrm{Ca}$ ratios, indicative of more geochemically evolved groundwater, were measured in samples collected across the study area from Uvalde County to Comal County. Historical data for samples from several of the confined wells located across the study area had relatively small but temporally consistent changes in $\mathrm{Mg} / \mathrm{Ca}$ ratios; that is, they had time series of increasing and decreasing $\mathrm{Mg} / \mathrm{Ca}$ ratios that varied in a similar pattern (for example, time series from wells YP-69-45-405, TD-69-46-601, TD-69-47-303, DX-68-23-303, and DX-68-23-601) (fig. 26A). This consistent variability likely reflects regional-scale changes in hydrologic conditions; higher $\mathrm{Mg} / \mathrm{Ca}$ ratios are associated with longer residence time and corresponding drier hydrologic conditions (low aquifer flow conditions). The small range of variability for samples collected from individual wells is consistent with the hypothesis that most confined wells, unless intersecting a fast-flow conduit, are generally dominated by longer residence time matrix-dominated flow and attenuation of the inputs from storm and recharge events. The geochemistry of matrix groundwater is more stable and changes slowly in response to longer term regional hydrologic conditions.

Only one of the wells with historical major ion data also has water-level altitude data available for the same time period (1970-2006, site TD-69-46-601, Medina County), which are compared to discharge at Comal Springs (fig. 26B) and to $\mathrm{Mg} / \mathrm{Ca}$ ratios for groundwater from the well (fig. 26C). Although geochemical data and water-level altitude data are not available for the same dates of measurement or at the same time scales, water-level altitude variations in the well are similar to discharge values at Comal Springs (fig. 26B). Lower water-level altitudes in well TD-69-46-601 are associated with higher $\mathrm{Mg} / \mathrm{Ca}$ ratios, reflecting greater extents of mineral-solution reaction and longer residence time in response to drier hydrologic conditions (lower aquifer flow conditions) (fig. 26C). The relation between $\mathrm{Mg} / \mathrm{Ca}$ ratios and water-level altitude data for this well is consistent with the hypothesis that temporal variations in residence time and hydrologic conditions control variations in fluid geochemistry over multiple time scales.

\section{Groundwater Age Tracers and Travel Times}

Estimating the age of groundwater is useful for understanding selected aspects of hydrogeology, such as groundwater flow and mixing. Groundwater age estimates have been used to determine recharge rates, estimate rates of geochemical and microbiological processes, calibrate groundwater flow models, evaluate aquifer susceptibility to contamination, and improve water-resource management (Plummer, 2005). Techniques for dating groundwater estimate the time passed since recharge of that groundwater occurred. Groundwater age estimates are based on the measurement of a dissolved solute, gas, or isotope in groundwater that has been transported through the aquifer to the point of sampling; as such, groundwater age estimates are model-dependent, based on an interpretation of recharge and flow mechanisms, and might be affected by a variety of physical and geochemical processes (Cook and Böhlke, 2000; Plummer, 2005). Because it is not possible to identify and account for all physical and chemical processes that might affect groundwater age-tracer results, the "apparent age" of groundwater is most appropriately reported. Groundwater age tracers have historically included measurements of tritium $\left({ }^{3} \mathrm{H}\right)$ and carbon- $14\left({ }^{14} \mathrm{C}\right)$; recent advances for interpreting groundwater age information in the 0 - to 50 -year time scale include concentrations of anthropogenic atmospheric gases in groundwater, such as chlorofluorocarbons (CFCs) and sulfur hexafluoride $\left(\mathrm{SF}_{6}\right)$, and the ratio of the parent/daughter isotopic system of tritium/helium-3 $\left({ }^{3} \mathrm{H} /{ }^{\beta} \mathrm{He}\right)$ (Plummer, 2005).

Geochemical age tracers, including ${ }^{3} \mathrm{H}, \mathrm{CFCs}$, and $\mathrm{SF}_{6}$, have been applied in NAWQA studies of several aquifers, and numerous studies have addressed their application and utility (Michel, 1989; Busenberg and Plummer, 1991; Plummer and others, 1993; Busenberg and Plummer, 2000; Katz and others, 2001; Plummer and Busenberg, 2005; International Atomic Energy Agency, 2006; Busenberg and Plummer, 2008). ${ }^{3} \mathrm{H}$, CFCs (CFC-11, CFC-12, and CFC-113), and $\mathrm{SF}_{6}$ tracers were measured on a majority of NAWQA samples of groundwater from the Edwards aquifer, some in combination. Results for apparent age tracers are summarized in table 6 (at end of report); details of the analyses are provided in appendix 6 for ${ }^{3} \mathrm{H}$ and in appendix 10 for $\mathrm{CFCs}$ and $\mathrm{SF}_{6}$. Many of the $\mathrm{CFC}$ and $\mathrm{SF}_{6}$ results are indicative of contamination of the sample by non-atmospheric sources (that is, the measured tracer concentration in the groundwater sample was greater 


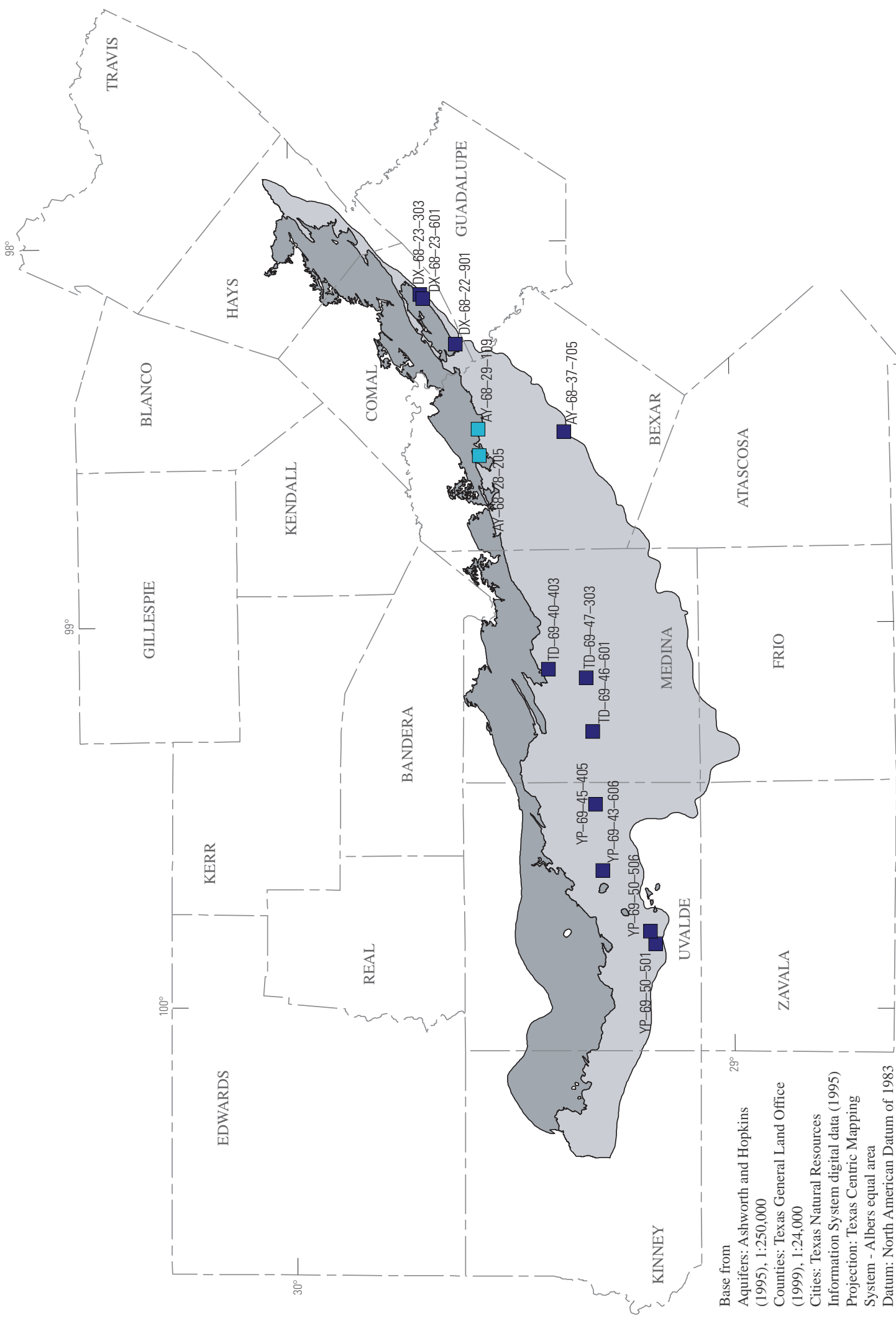

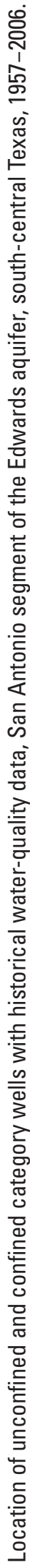




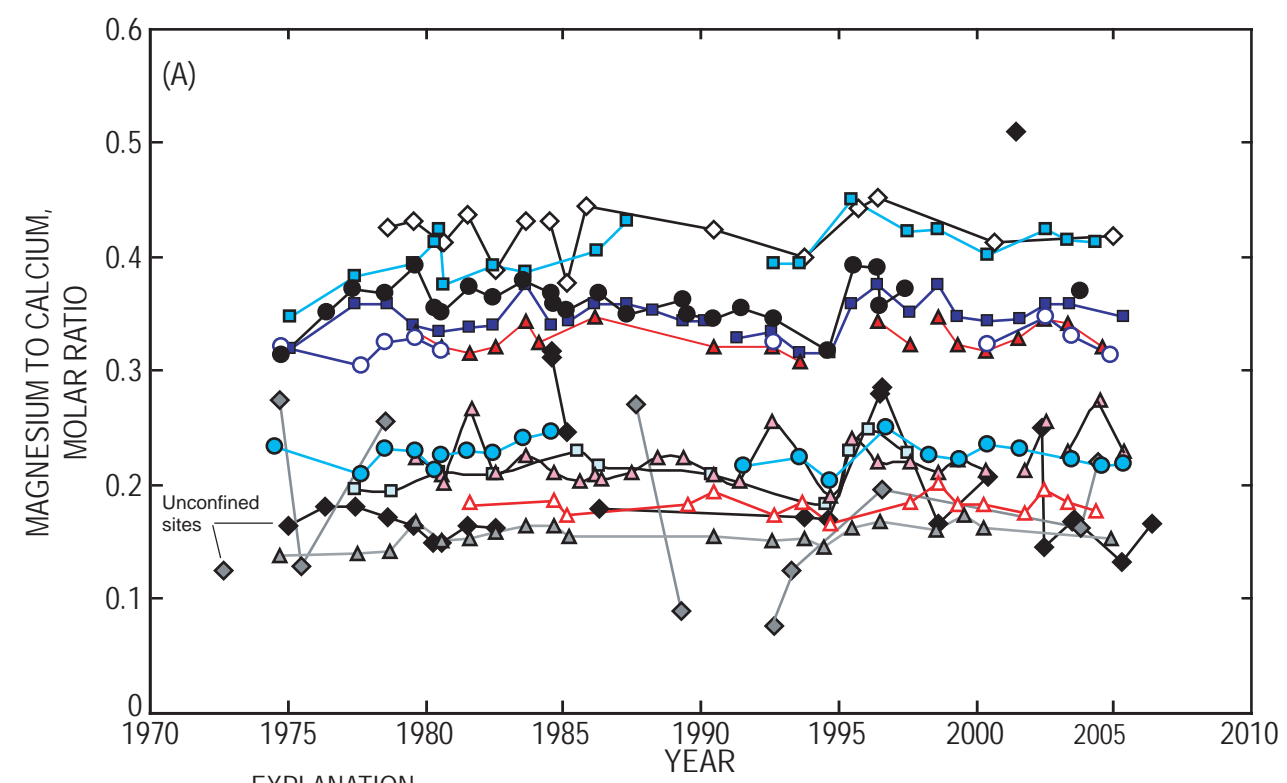

EXPLANATION

Well number, county and category

$\longrightarrow$ AY-68-29-109, Bexar, unconfined

$\checkmark$ AY-68-28-205, Bexar, unconfined

$\smile$ AY-68-37-705, Bexar, confined

$\rightarrow$ TD-69-46-601, Medina, confined

- - TD-69-47-303, Medina, confined

$\rightarrow \square-T D-69-40-403$, Medina, confined

$-\Delta$ YP-69-43-606, Uvalde, confined
$\Delta$ YP-69-45-405, Uvalde, confined
$\Delta$ YP-69-50-501, Uvalde, confined
$\Delta$ YP-69-50-506, Uvalde, confined
-0 DX-68-23-601, Comal, confined
- DX-68-22-901, Comal, confined
$\longrightarrow$ - DX-68-23-303, Comal, confined
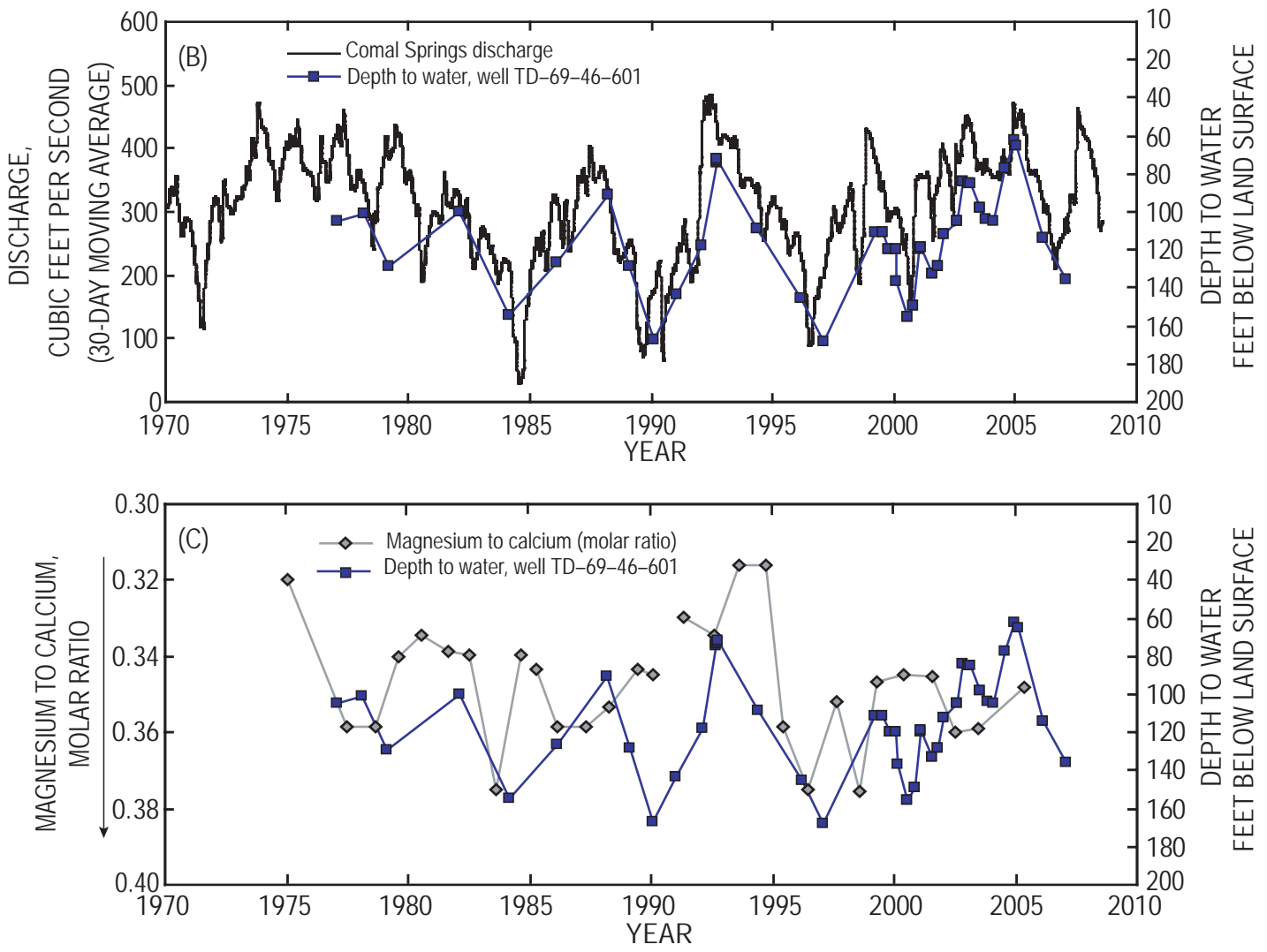

Figure 26. Comparison of (A) time series of magnesium to calcium (molar ratio) for 13 wells (two unconfined category and 11 confined category); (B) historical relation between Comal Springs discharge and depth to water at well TD-69-46-601 (confined category, Medina County); and (C) time series of magnesium to calcium (molar ratio) (note inverted scale) and depth to water at well TD-69-46-601 (confined category, Medina County), San Antonio segment of the Edwards aquifer, south-central Texas, 1970-2007. 
than the theoretically possible tracer concentration, based on equilibrium of the groundwater sample with the maximum atmospheric concentration) and, as a result, did not yield resolvable apparent ages. Apparent ages for all groundwater samples ranged from about 1 to 52 years, with a median of 20 years; results indicate that groundwater in the Edwards aquifer is dominated by "young" or "modern" water, with extensive groundwater mixing. "Young" groundwater is defined as water recharged within approximately the past 50 years, the time scale for which is largely defined by the dating range of applicable environmental tracers (Plummer and Friedman, 1999; Plummer and Busenberg, 2005). "Modern" groundwater has been defined similarly, that is, water that has recharged within the past few decades and is part of an active hydrologic cycle (Clark and Fritz, 1997). In this report, because all groundwater apparent ages are young, modern groundwater is used to represent samples with apparent ages that belong to the present day, that is, within 10 years of the time of sampling. Results for apparent groundwater age measurements for groundwater samples from the Edwards aquifer are consistent with the regional hydrogeology, previous studies, and results of dyetracing tests performed in the aquifer that document a large range of travel times and groundwater mixing (Pearson and others, 1975; Campana and Mahin, 1985; Ogden and others, 1986; Johnson and Schindel, 2008).

Preliminary apparent age interpretations for $\mathrm{CFC}$ and $\mathrm{SF}_{6}$ tracer results were provided by the USGS Chlorofluorocarbon Laboratory, Reston, Va., and are based on a piston-flow model (Niel Plummer, U.S. Geological Survey, written commun., 2009). In spite of the analytical precision available for measurement of many geochemical age tracers, there are a variety of uncertainties associated with the interpretation of these data and determining the apparent age of a groundwater sample (Phillips and Castro, 2003; Bethke and Johnson, 2008). Age interpretation for a sample that consists of water of a single age might be relatively simple but becomes increasingly complex for a sample that consists of a mixture of water of varying ages (Böhlke, 2006). As described by Long and Putnam (2006), this might be especially important in karst aquifers, where each component of a complex network of conduits, fractures, and matrix porosity might have a different groundwater age and a well or spring might discharge water from any combination of porosity types (Plummer and Busenberg, 2005). Models for the hypothetical concentrations of age tracers in water samples with different age distributions that consider the effect of hydrologic processes such as dispersion, exponential mixing, and binary mixing of shallow and deep groundwater have been developed to facilitate interpretation of geochemical age tracers (Böhlke, 2006; Long and Putnam, 2006). A piston-flow model, which is the simplest and most common transport assumption, assumes that the tracer concentration was not altered by transport processes (Plummer and Busenberg, 2005). This simplified approach likely does not adequately describe the range of ages in a mixed sample, especially for karst aquifers (Long and Putnam, 2006). In spite of these uncertainties in age interpretation, piston-flow model ages provide an initial reference point for comparison of different age tracers and time scales of flow processes in the aquifer. Age tracers might not be well suited to distinguish small differences in groundwater ages measured in samples collected from individual wells in the Edwards aquifer, but they provide insight into how changing hydrologic conditions affect groundwater recharge and mixing. Results indicate that while apparent groundwater ages are consistently young, the apparent age measured in individual samples varies as a result of changing hydrologic conditions. That is, variability in hydrologic conditions results in different mixtures of groundwater of different apparent ages. More detailed evaluation of apparent age tracer data for the Edwards aquifer with respect to different hydrodynamic and geochemical processes that might affect tracer concentrations and groundwater mixtures is a topic of ongoing research.

Contamination can affect apparent groundwater ages determined using $\mathrm{CFC}$ and $\mathrm{SF}_{6}$ concentrations, particularly in urban areas. Results for a majority of the CFC tracer concentrations measured in Edwards aquifer groundwater samples indicate that $\mathrm{CFC}$ contamination might be widespread-in particular for CFC-11 and CFC-12 in shallow/urban unconfined groundwater samples (table 6). This hypothesis is consistent with a previous study of the Edwards aquifer documenting CFC contamination (Thompson and Hayes, 1979). As a result, resolvable CFC-based groundwater apparent ages might still be affected by excess CFC from widespread aquifer contamination; apparent ages based on CFC concentrations might be questionable. Results are discussed below only for samples that clearly are not contaminated. Contaminant concentrations of CFCs, which might be attributed to anthropogenic sources such as septic tanks, leaking sewer lines and storage tanks, sewage treatment plant effluent, and industrial wastes, would tend to bias apparent ages to younger values (Plummer and Busenberg, 2005). CFC tracer concentrations measured in samples collected from the deeper unconfined part of the aquifer in 2006 and $\mathrm{SF}_{6}$ tracer concentrations measured in shallow/ urban unconfined groundwater samples collected in 2006 have notably less apparent contamination relative to other samples (table 6, appendix 10).

\section{Tritium}

The most frequently measured age tracer was ${ }^{3} \mathrm{H}$, a radioactive isotope of hydrogen with a half-life of 12.43 years (Unterweger and others, 1980). ${ }^{3} \mathrm{H}$ in rainfall is from two sources, either natural cosmogenic ${ }^{3} \mathrm{H}$ or produced by atmospheric testing of nuclear weapons and nuclear reactors. Given its relatively short half-life, the presence of ${ }^{3} \mathrm{H}$ in groundwater is indicative of recent groundwater recharge (Clark and Fritz, 1997; Plummer, 2005). The input of ${ }^{3} \mathrm{H}$ to the atmosphere as a result of nuclear testing dominated the concentrations of ${ }^{3} \mathrm{H}$ in rainfall for about 50 years, with concentrations peaking in the 1960s. Pre-bomb background atmospheric ${ }^{3} \mathrm{H}$ concentrations were about 2 to 10 Tritium Units (TU); ${ }^{3} \mathrm{H}$ concentrations in 


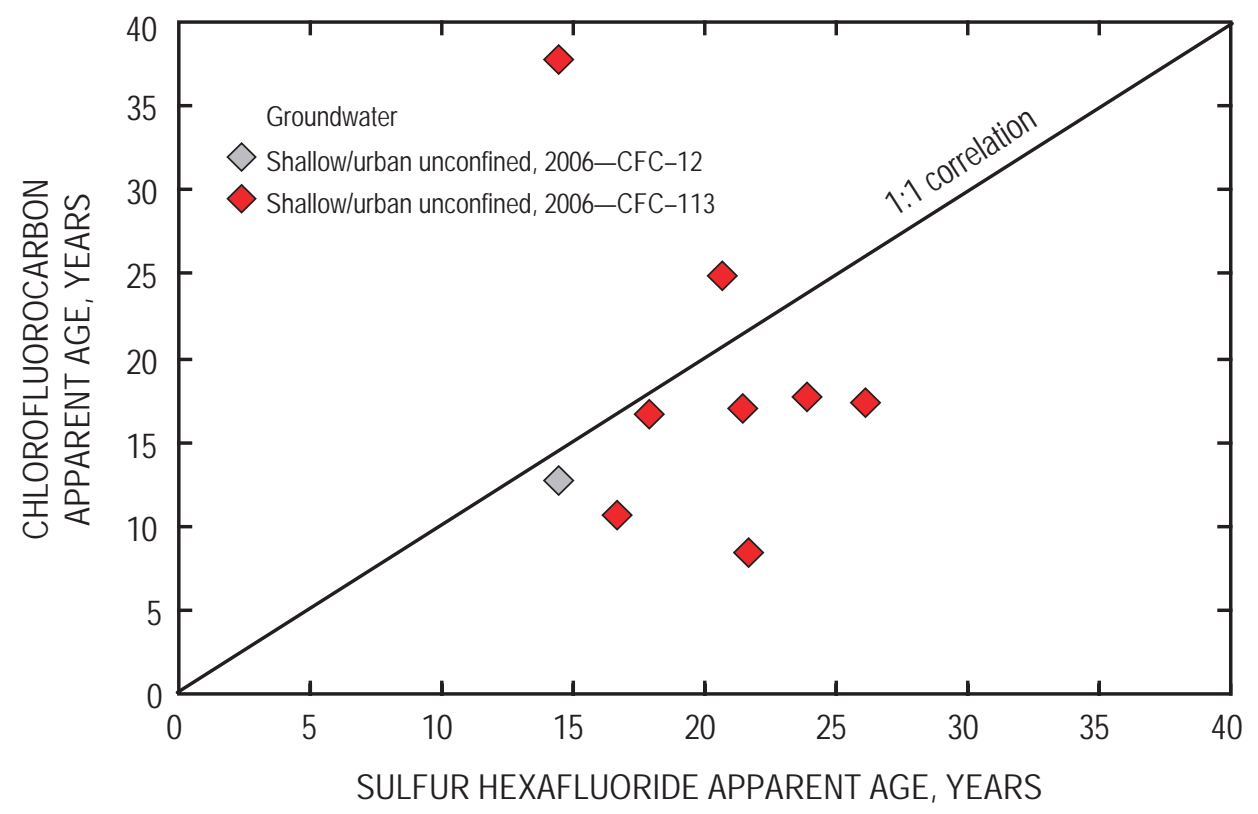

Figure 27. Relation between groundwater apparent ages for chlorofluorocarbon (CFC) (CFC-12 or CFC-113) and sulfur hexafluoride tracers for groundwater samples collected from shallow/urban unconfined category wells, San Antonio segment of the Edwards aquifer, south-central Texas, 2006.

recent rainfall (since 2006) have globally decreased to approximately pre-bomb background levels (Clark and Fritz, 1997; Phillips and Castro, 2003; Robert Michel, U.S. Geological Survey, written commun., 2009).

Concentrations of ${ }^{3} \mathrm{H}$ measured in samples of Edwards aquifer groundwater collected during 1996-2006 ranged from 0.3 to $4.6 \mathrm{TU}$, with a median of $2.6 \mathrm{TU}$. Twenty-six shallow/ urban unconfined wells were sampled twice for ${ }^{3} \mathrm{H}$, in 1998 and again in 2006. ${ }^{3} \mathrm{H}$ concentrations at most of these wells were lower in 2006 (median $=2.0 \mathrm{TU}$ ) compared to concentrations in 1998 (median $=2.9 \mathrm{TU}$ ) (data are statistically different on the basis of Mann-Whitney U test results), which is consistent with ${ }^{3} \mathrm{H}$ decay in the atmosphere and in groundwater over this 8-year period. Groundwater ${ }^{3} \mathrm{H}$ concentrations were compared to a local ${ }^{3} \mathrm{H}$ input function derived from a combination of ${ }^{3} \mathrm{H}$ concentrations measured in rainfall at Waco, Tex. (1961-87) and ${ }^{3} \mathrm{H}$ concentrations measured in rainfall at Vienna, Austria (1961-2006). Results for ${ }^{3} \mathrm{H}$ concentrations for Edwards aquifer groundwaters indicate a dominant component of young and modern water throughout the aquifer, with similar values in all parts of the aquifer characterized in this report (table 3, appendix 6). Mixtures of water ranging in age from modern to approximately 20 years cannot be readily distinguished on the basis of ${ }^{3} \mathrm{H}$ values. Relatively low values (less than $1 \mathrm{TU}$ ) were measured in samples collected in 1997 from three wells in the confined part of the aquifer (appendix 6), which might indicate a mix of water of different ages, including a component of older sub-modern water (that is, water recharged more than 50 years ago). These three wells are in the western part of the aquifer (Uvalde and Medina Counties), with depths ranging from approximately 500 to 2,500 ft below land surface.

\section{Chlorofluorocarbons and Sulfur Hexafluoride}

CFC tracer data (CFC-11, CFC-12, and CFC-113) were measured for most of the samples collected from shallow/ urban unconfined wells in $1998(\mathrm{n}=29)$ and in $2006(\mathrm{n}=$ 22) and for samples collected from unconfined groundwater wells in $2006(n=30)$ (appendix 10). Additionally, the tracer $\mathrm{SF}_{6}$ was measured in 22 samples collected from shallow/ urban unconfined wells in 2006. Analytical results indicate that some of the samples were contaminated with excess tracer and do not yield resolvable apparent ages. Results of apparent age tracers for uncontaminated samples indicate that the shallow/urban unconfined part of the aquifer consists of young, recently recharged water, ranging in apparent age from modern (about 1 year) to about 38 years, with a median apparent age of 14.5 years. These young ages are consistent with the rapid recharge and high groundwater flow rates of the shallow unconfined part of aquifer. When apparent ages could be estimated in individual samples using multiple CFC tracers (that is, uncontaminated results were available for a combination of two or more of the CFC tracers), the apparent age results were generally in good agreement (table 6; appendix 10). This occurred most often for samples collected from the unconfined part of the aquifer in 2006. Where CFC (mostly $\mathrm{CFC}-113)$ and $\mathrm{SF}_{6}$ apparent ages were measured in samples collected from shallow/urban unconfined wells in 2006 ( $\mathrm{n}=$ 9), the results indicate young apparent ages for both tracers, although results do not yield concordant ages (fig. 27). This lack of precise agreement is not uncommon for groundwater apparent age tracer data; it has been proposed that although groundwater ages indicated by various tracers might differ, each tracer could still provide unique insights into different 
components of the mixed water history, and thus multiple tracers might have much greater utility in interpreting groundwater apparent age tracer results (Glynn and Plummer 2005; Bethke and Johnson, 2008).

The median apparent groundwater age using CFC concentrations measured in shallow/urban unconfined category samples collected in 1998 (12 years) is less than that for samples collected from the same group of shallow/urban unconfined category wells in 2006 (18 years). Apparent groundwater CFC age results for the shallow/unconfined category samples collected in 1998 and 2006 were statistically different on the basis of Mann-Whitney $U$ test results. These results are consistent with differences in hydrologic conditions associated with these two periods, with relatively wet conditions in 1998 (larger amount of recharge and larger proportion of modern water) and drier conditions in 2006 (smaller amount of recharge and smaller proportion of modern water). These results indicate that apparent groundwater age in a dynamic karst system such as the Edwards aquifer reflects mixtures of young and modern water, the proportions of which vary temporally as a result of changes in hydrologic conditions. Temporal variability in apparent age results for karst groundwater as a result of hydrologic conditions has been previously demonstrated in the Floridan aquifer (Happell and others, 2006) and indicates that a one-time sampling of karst groundwater might not provide representative apparent ages.

The apparent age of groundwater has been used to estimate flow paths and residence time (for example, Cook and Böhlke, 2000). Based on available NAWQA data, this application is limited for the Edwards aquifer, partly because of the small number of age-tracer measurements in samples collected from the more geochemically evolved groundwater from the confined part of the aquifer. Apparent age results for samples collected from the relatively shallow unconfined part of the aquifer (shallow/unconfined category) (median of 14.5 years) were younger than results for samples collected from the deeper unconfined part of the aquifer (unconfined category) (median of 24.1 years) and were statistically different on the basis of Mann-Whitney U test results. This comparison between apparent ages for samples of relatively shallow unconfined groundwater and deeper unconfined groundwater might be biased, however, by differences in hydrologic conditions during sampling periods. Apparent age tracers were measured in samples collected from shallow/ urban unconfined category wells in 1998 (a relatively wet year with younger apparent ages) and 2006 (a relatively dry year with older apparent ages), but apparent age tracers were measured in samples collected from the deeper unconfined part of the aquifer only in 2006. Nonetheless, if apparent ages for only samples collected in 2006 are compared, the median apparent age for shallow/urban unconfined category wells was 17.9 years, which is slightly younger than for samples from the deeper unconfined part of the aquifer (24.1 years); apparent ages for these two sample groups collected in 2006 were still statistically different on the basis of Mann-Whitney U test results.
$\mathrm{Mg} / \mathrm{Ca}$ ratios, which can be used as a qualitative indicator of groundwater residence time, are compared to apparent age results for $\mathrm{CFC}$ and $\mathrm{SF}_{6}$ data from 1998 (shallow/urban unconfined groundwater category) and 2006 (shallow/urban unconfined and unconfined groundwater categories) in fig. 28 (no apparent age tracer measurements other than ${ }^{3} \mathrm{H}$ were collected from the confined part of the aquifer). Results for $\mathrm{Mg} / \mathrm{Ca}$ ratios and apparent groundwater ages are poorly correlated; only one correlation is statistically significant for any specific tracer. That correlation, between $\mathrm{Mg} / \mathrm{Ca}$ ratios and the apparent age from $\mathrm{SF}_{6}$ concentrations for shallow/urban unconfined category samples collected in 2006 is negative (Kendall's tau $=-.41$ ), which is inverse to what would be expected on the basis of the previously discussed relation of lower $\mathrm{Mg} / \mathrm{Ca}$ ratios associated with younger groundwater. These results indicate that the complexities associated with $\mathrm{CFC}$ and $\mathrm{SF}_{6}$ age-tracer methods in this aquifer, including potential contamination and use of appropriate mixing models, might limit their application beyond providing insight into the young nature of the groundwater.

\section{Flow Model Estimates of Travel Times and Flow Rates}

Previous NAWQA studies have compared groundwater age-tracer results to estimates of flow rates and travel times from hydrogeologic models in other aquifer systems (Clark and others 2007; Burrow and others 2008; Jurgens and others, 2008; Landon and others, 2008). In a similar way, groundwater age tracers measured in samples collected from the Edwards aquifer can be compared to estimates of flow rates and travel times from two groundwater flow models of the Edwards aquifer (Lindgren and others, 2004; Lindgren, 2006) done using MODFLOW2000 (Harbaugh and others, 2000). The first model includes simulated, continuously connected conduits, as well as barrier faults, that strongly influence subregional flow (hereinafter, the conduit-flow model; Lindgren and others, 2004). In the second model, without simulated conduits (hereinafter, the diffuse-flow model), flow occurs through a network of numerous small fractures and openings; this model includes zones of upscaled hydraulic conductivity (Lindgren, 2006). Both models were calibrated for steadystate and transient conditions. Detailed descriptions of model development, calibration, and sensitivity tests are included in Lindgren and others (2004) and Lindgren (2006).

Particle-tracking simulations in the models (MODPATH; Pollock, 1994) were used to estimate particle travel times and areas contributing recharge for a majority of the NAWQA wells (these wells were previously included in model calibrations: $n=113$ for the conduit-flow model and $n=115$ for the diffuse-flow model). MODPATH uses the cell-by-cell flow values calculated by MODFLOW to calculate the groundwater flow velocity distribution in the groundwater system, which is then used to determine flow paths of water particles moving through the aquifer (Pollock, 1994). Travel times along flow paths are computed using the magnitude of the cell-by-cell 

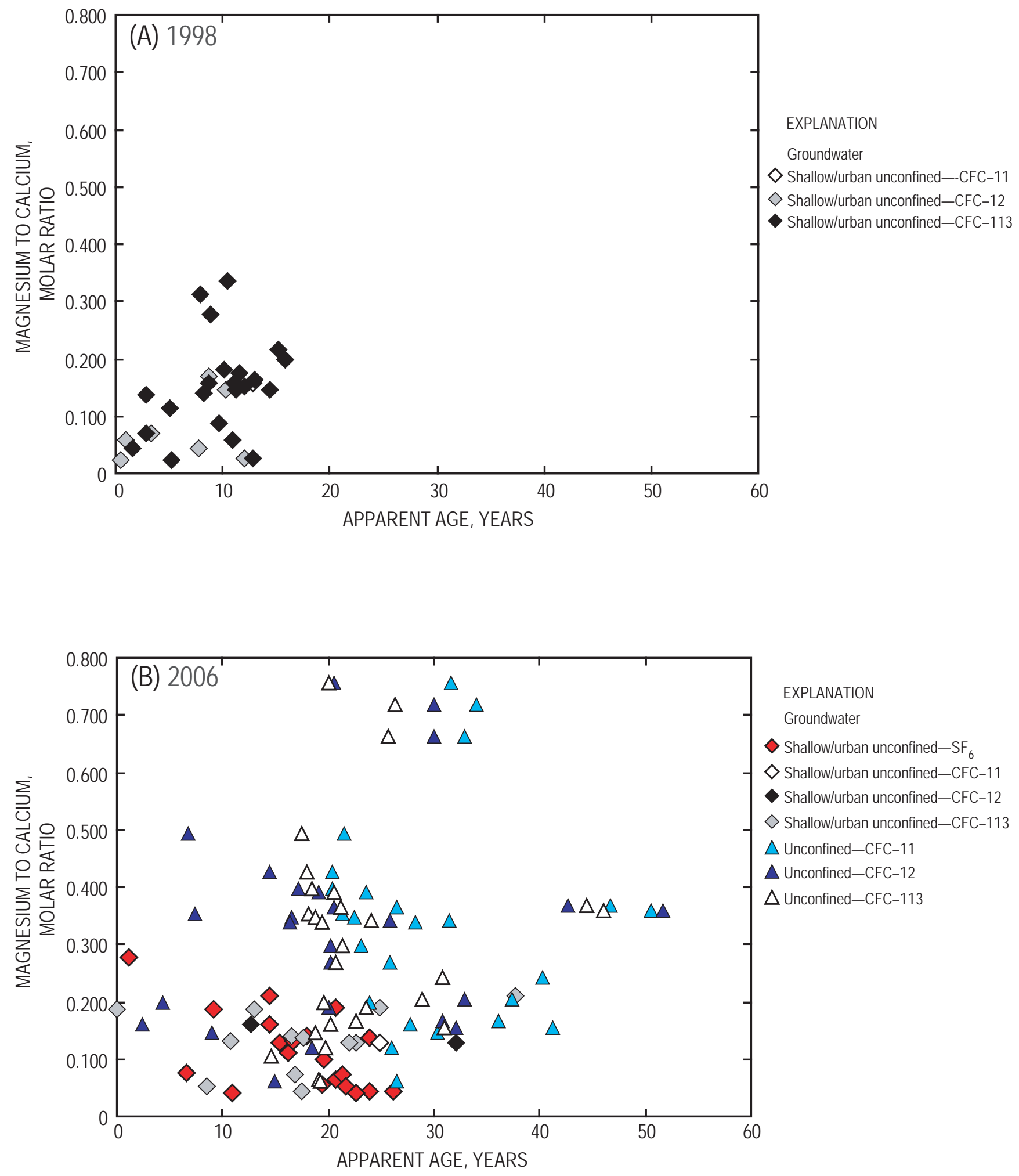

Figure 28. Relation between magnesium to calcium (molar ratio) and apparent age for groundwater samples collected from shallow/ urban unconfined and unconfined parts of the San Antonio segment of the Edwards aquifer, south-central Texas, (A) 1998 and (B) 2006. 


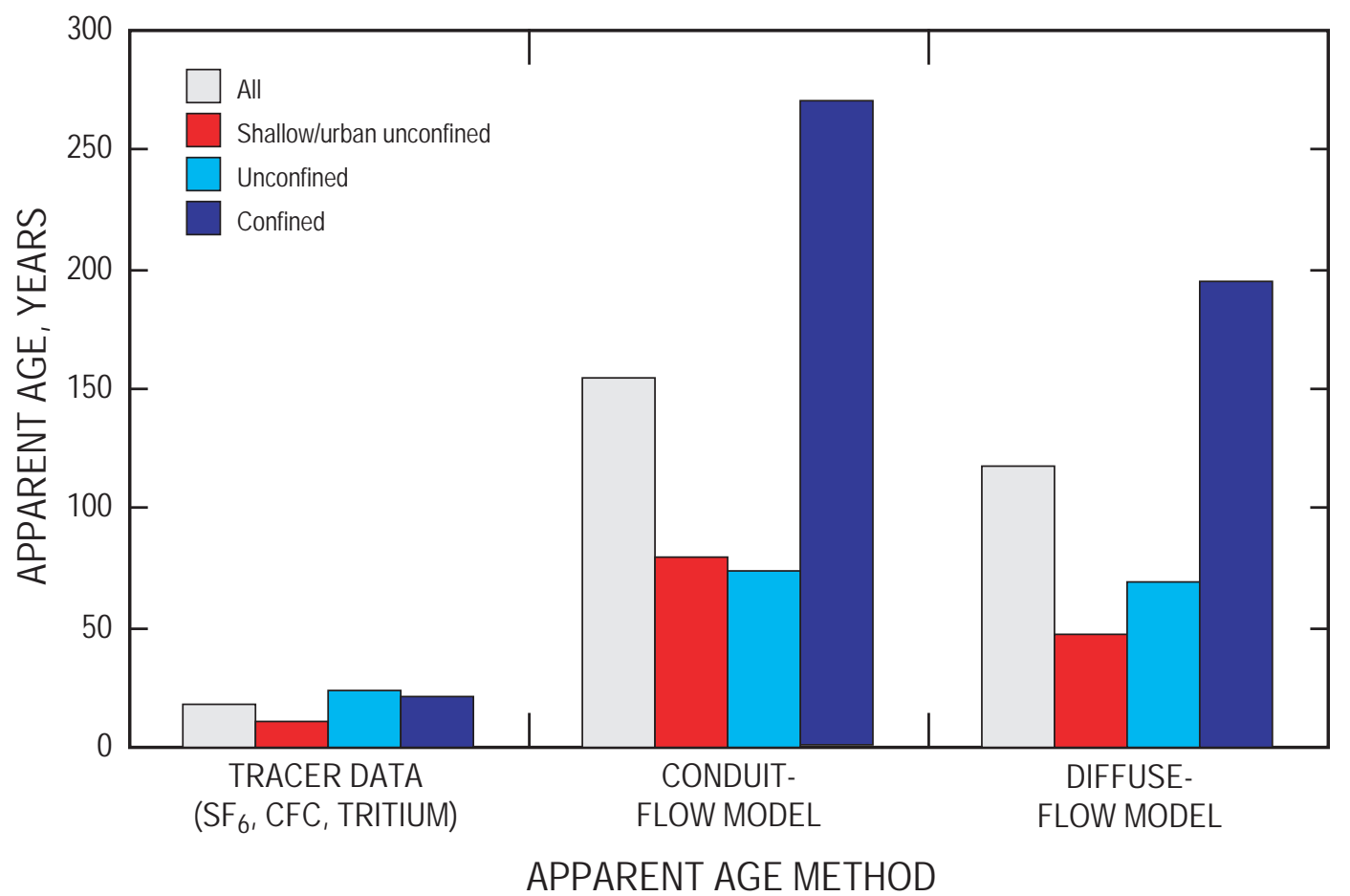

Figure 29. Comparison of apparent ages determined from geochemical age tracers (sulfur hexafluoride, chlorofluorocarbons, and tritium) for groundwater samples collected from shallow/urban unconfined, unconfined, and confined parts of the San Antonio segment of the Edwards aquifer, south-central Texas, 1996-2006, with mean particle-track travel-time estimates derived from conduit-flow and diffuse-flow models for the Edwards aquifer (Lindgren and others, 2004; Lindgren, 2006).

Tracer data results for shallow/urban unconfined and unconfined categories represent the median value for each sample category based on all sulfur hexafluoride and chlorofluorcarbon apparent ages; results for the confined category are based on tritium data and represent the range of likely apparent groundwater ages.

$\left[\mathrm{SF}_{6}\right.$, sulfur hexafluoride; CFC, chlorofluorocarbon (CFC-11, -12 , or -113)]

flows, porosity, and model cell dimensions. MODPATH calculates advective flow only and does not account for effects of mechanical dispersion and (or) chemical reaction on groundwater transport.

Model results can be used to estimate the travel time and, correspondingly, an interpreted age of water at each well. The steady-state calibrations of both the conduit-flow and diffuseflow models, with an estimated average effective porosity value of 0.18 (based on Hovorka and others, 1996), were used to determine backward-tracking particle travel times for comparison to geochemical age-tracer results. A total of 100 particles were specified for each well, spaced uniformly along the open or screened interval. The resulting travel time for each particle might vary, depending on its starting position. All resulting particle tracks for each well were used to calculate minimum, maximum, and mean travel times (appendix 11). Additionally, the mean particle travel distance was computed to provide an estimate of flow path length and, in conjunction with mean particle travel time, to estimate a mean flow rate associated with each well (table 7, at end of report).
Results of particle tracking for the conduit-flow and diffuse-flow models are compared to results for geochemical apparent age tracers collected for these wells (fig. 29). There is little agreement between the apparent groundwater ages estimated by the two approaches. Geochemical apparent age tracer results are approximately one order of magnitude younger than mean model particle-track travel-time results. For the model results, the diffuse-flow model tends to yield slightly shorter travel times than the conduit-flow model. These differences result from differences between the hydraulic conductivity distributions of the two models; particle-track pathlines and, correspondingly, travel times tend to align with zones of high hydraulic conductivity. In the conduit-flow model, these zones are a one-model-cell-wide, continuously connected network of conduits. In the diffuse-flow model, higher hydraulic conductivity zones are generally wider than one cell. Particle-track travel times calculated by MODPATH are proportionally sensitive to model porosity values. Because of the karstic nature of the groundwater flow, including mixing between conduit and matrix flow components, the regional 
average effective porosity of 0.18 used in the model might not be applicable at the scale of local karst conditions. Differences between geochemical age-tracer results and model particletrack travel-time calculations raise many research questions and are topics of ongoing investigation. The comparison of flow model and geochemical age-tracer results in this report indicate that existing flow models might not accurately represent the rapid, fast-flow (conduit-dominated) component of this karstic aquifer. This is also demonstrated by results of dye-tracing tests in northern Bexar County that indicate groundwater velocities of 13 to 5,283 meters per day (Johnson and others, 2009), which are orders of magnitude higher than model results. These fast flow paths might include flow occurring through local-scale karst dissolution features and local- to regional-scale conduits. The current limitations of distributed porous media models to simulate flow in a karst system including, specifically, limitations with the simulation of rapid flow in conduits and travel times for contaminants are well recognized (Lindgren and others, 2004) and an area of ongoing research efforts. Although the absolute values for particletrack travel times appear unrealistically long, the model results show a clear progression toward longer flow paths and longer travel times from the unconfined to the confined part of the aquifer, which is consistent with geochemical interpretations and aquifer hydrology.

\section{Implications for Monitoring for Water- Quality Trends in Karst}

Over 2 decades, the NAWQA Program has applied nationally consistent procedures for sample site selection, sampling, analytical methods, and data management. As a result, studies are comparable across different aquifer systems and have been used to examine natural factors and anthropogenic practices that affect water quality. Application of a consistent study approach has allowed examination of natural factors and anthropogenic practices that affect water quality in a broad range of spatial scales and environmental settings and has provided national scale insights into water quality (for example, Gilliom and others, 2006; Zogorski and others, 2006; McMahon and others, 2009). NAWQA studies of the San Antonio segment of the Edwards aquifer conducted during 1996-2006 have yielded extensive water-quality data, including water-quality data from different parts of the aquifer (shallow/urban unconfined, unconfined, and confined categories). These data are useful for assessing the status of water quality and regional hydrologic processes that affect geochemistry. The analysis of temporal trends or evaluation of the relation between groundwater quality and hydrologic conditions is constrained by few time-series data. To assess long-term changes in groundwater quality, an understanding of the relation between variability in water quality and hydrologic conditions on different time scales is needed, particularly in karst settings. Collection of data at selected integrator sites (for example, for the Edwards aquifer, major discharge points such as Comal Springs and carefully selected wells) on different time scales and associated with different hydrologic conditions would address multiple time scales of aquifer variability (from event-based, short-term to intermediate and long-term) to allow for understanding of both aquifer hydrology and shortand long-term trends in water quality.

An understanding of the relation between variability in water quality and hydrologic conditions provides a foundation on which to assess long-term changes in water quality. For example, if concentrations of a contaminant increase over time, but knowledge of the expected relation between that constituent and hydrologic conditions indicates that constituent concentrations should decrease over that same time period, the trend might be independent of changes in hydrologic conditions. A variable-interval sampling program might be designed to target high or low aquifer flow conditions or to relate sampling intervals to periods of similar hydrologic conditions to distinguish between short-term/hydrologically induced variation and longer-term trends. A monitoring design for a karst system should be based directly on monitoring goals (Quinlan, 1989). A long-term monitoring program design that includes sampling of matrix- and conduit-dominated flow components, springs, and surface-water recharge under a variety of flow conditions (including base flow and event flow) could provide comprehensive understanding of the water quality of the Edwards aquifer and variability of water quality as a result of different hydrologic conditions. A monitoring design that includes specific integrator sites necessitates some prior knowledge of aquifer processes and aquifer response to recharge events. Continuous monitoring of physicochemical conditions such as water-level altitude, specific conductance, and turbidity can be used to guide sample site selection and frequency of sample collection. A high sampling frequency, especially under storm-event conditions, might be needed to assess rapid changes in water quality that have been shown to occur in karst aquifers (for example, Mahler and Massei, 2007). An ideal sampling frequency needs to be flexible and driven by hydrologic conditions. Such an approach would supplement previous NAWQA studies and facilitate assessment of trends in water quality in karst settings such as the Edwards aquifer. When monitoring programs are intended to provide the data necessary to assess long-term trends and increase understanding of karst aquifer functioning, time scales of hydrologic and geochemical variability need to be carefully considered.

\section{Summary}

During 1996-2006, the U.S. Geological Survey collected and analyzed groundwater samples from the San Antonio segment of the Edwards aquifer as part of the National Water-Quality Assessment (NAWQA) Program. This report evaluates those data to assess (1) hydrologic processes in the Edwards aquifer such as mineral-solution reactions and 
groundwater geochemical evolution, (2) spatial and temporal (time-series) data for natural and anthropogenic constituents, (3) the relation between geochemistry and water quality with hydrologic conditions, (4) the utility of geochemical age tracers, and (5) a comparison of age-tracer data with existing flow models, to develop an integrated understanding of karst and aquifer processes. Implications for monitoring water-quality trends in karst are also discussed. Given the large number of analytical constituents that have been analyzed for samples of groundwater collected throughout the Edwards aquifer, this report presents an overview of variability in groundwater geochemistry and water quality, and controlling processes in the San Antonio segment of the aquifer. The dataset includes 249 groundwater samples from 136 sites throughout the southcentral Texas (SCTX) study unit, including samples from four springs. Sampling primarily occurred during 1996-98 and again during 2005-06. A small subset of wells was sampled repeatedly during 1999-2004. For this analysis, groundwater samples were grouped into categories of "shallow/urban unconfined," "unconfined," and "confined." These categories are representative of groundwater evolution along a hypothetical flow path encompassing endmembers of (1) shallow, unconfined, younger, less geochemically evolved groundwater (shallow/urban unconfined category) and (2) deep, confined, older, more geochemically evolved groundwater (confined category). Unconfined groundwater is intermediate between these two endmembers in this conceptual flow path. Samples collected from shallow unconfined (water-level) monitoring wells in residential or commercial land-use settings in the urban San Antonio recharge zone (outcrop area) of the aquifer (northern Bexar Country) were categorized as shallow/urban unconfined groundwater, representing the shallow unconfined part of the aquifer and the urbanized part of the aquifer. Samples collected from recharge zone (outcrop area) wells located randomly throughout the aquifer were categorized as unconfined groundwater. Samples collected from wells completed in the confined part of the aquifer and from springs discharging from the confined part of the aquifer were categorized as confined groundwater. Monitoring wells from which samples in the shallow/urban unconfined category were collected are relatively shallow (median well depth of $263 \mathrm{ft}$ below land surface). Wells from which samples in the unconfined and confined categories were collected, in comparison, have median well depths of 385 and $859 \mathrm{ft}$ below land surface, respectively (excluding those with unknown well depths).

The central Texas Edwards aquifer is a highly productive karst aquifer developed in Early Cretaceous carbonate rocks, and is an important water resource in a rapidly growing and urbanizing region. Karst groundwater systems are subject to rapid changes in flow and discharge rates, water-level altitudes, and water quality, and as a result, are susceptible to contamination. An understanding of the relation between variability in water quality and hydrologic conditions on different time scales including geochemical evolution processes, the spatial and temporal variability of groundwater geochemistry, and natural and anthropogenic effects on water quality is necessary for resource management as well as for sustainability of springflow for threatened and endangered species habitat. The Edwards aquifer, like many karst aquifers, is characterized by hydrologic variability-water-level altitudes in the aquifer can rise rapidly in response to rainfall and corresponding recharge, accompanied by increases in springflow; conversely, water-level altitudes and springflow decrease during periods of low rainfall and recharge. Changes in environmental, climatic, and hydrologic conditions can affect groundwater geochemistry and water quality. Temporal changes in hydrologic conditions such as water-level altitudes, recharge, travel times, and flow routing affect hydrogeologic processes, including the extent of variability in water-rock interaction processes, dilution of recharge, and associated geochemistry. Rapidly changing hydrologic conditions and a continuum of flow pathways from matrix to conduit flow imply that hydrogeologic processes might operate on different temporal and spatial scales in different parts of the aquifer. For example, groundwater dominated by matrix/diffuse flow or less affected by focused recharge might exhibit less temporal variability than groundwater influenced by focused recharge and conduit flow. Previous studies have used temporal variability in geochemistry of groundwater samples to investigate transport processes and the effect of changes in hydrologic conditions on water quality.

Geochemical and isotopic data are useful tracers of water-rock interaction processs, recharge, groundwater flow, and fluid mixing that affect water quality. An understanding of geochemical evolution processes provides information on groundwater residence times, endmember compositions, mixing processes, flow path length, and aquifer susceptibility to anthropogenic contaminants. Molar ratios of magnesium to calcium and strontium to calcium in groundwater typically increase along flow paths, and results for Edwards aquifer groundwater show an increase from shallow/urban unconfined, to unconfined, to confined groundwater categories. These differences are consistent with longer residence times and greater extents of mineral-solution reactions controlling fluid compositions as groundwater evolves from shallow unconfined groundwater to deeper confined groundwater. Molar ratios of magnesium to calcium and strontium to calcium in samples of Edwards aquifer groundwater were well correlated (Kendall's tau was .61). Overlapping ranges between different groundwater categories (shallow/urban unconfined groundwater, unconfined groundwater, and confined groundwater) suggest that water-rock interaction processes are spatially variable and likely are affected by local-scale differences in host limestone composition, soil composition, flow routes, and residence times. Despite these local-scale complexities, a regional pattern is evident. Strontium isotope results for Edwards aquifer groundwater, mostly for shallow/urban unconfined and unconfined samples show a progression toward lower isotopic values with higher magnesium to calcium and strontium to calcium molar ratios resulting from increased mineral-solution reaction as allowed by increased residence time and longer flow paths. Mass-balance modeling of progressive water-rock 
interaction processes supports this conclusion and is consistent with previous research in the aquifer that also includes other aquifer components such as soils and unsaturated zone cave dripwaters.

Stable isotopes of hydrogen and oxygen are commonly used in studies of hydrologic processes. Deuterium and oxygen isotope data indicate Edwards aquifer groundwater is composed of meteoric recharge. The relation between hydrogen isotopes and chloride concentrations indicates that specific geochemical processes have affected some groundwater samples, including (1) mixing with a component of more saline groundwater, (2) mixing with recent recharge associated with tropical cyclonic storms, and (3) mixing with recharge water that has undergone evaporation.

Samples of Edwards aquifer groundwater exhibit a relatively narrow range in major ion compositions across the region and are mostly dilute calcium-bicarbonate water. A small number of groundwater samples had elevated specific conductance values with relatively high concentrations of specific ions (chloride, sulfate, and (or) sodium). The geochemical composition of these samples indicates that they are influenced by mixing with more-saline water. Sources of saline water to Edwards aquifer groundwater are the underlying Trinity aquifer and (or) downdip saline-zone water, which might move up along faults and mix with fresh aquifer water. Variations in the sulfate to chloride ratio in relation to sulfate concentration, and the magnesium to sodium ratio in relation to magnesium concentration might allow for distinguishing between these two saline groundwater sources, and indicate mixing pathways with saline-water sources for samples with elevated specific conductance values.

Anthropogenic contaminants, such as nutrients, pesticides, and solvents are a national water-quality concern because of their potential detrimental effects on the environment and to human health. Median nitrate concentrations were similar in samples of the shallow/urban unconfined groundwater category and samples of the confined groundwater category (1.85 and $1.84 \mathrm{mg} / \mathrm{L}$, respectively), and lower in samples of the unconfined groundwater category $(1.09 \mathrm{mg} / \mathrm{L})$. Nitrite was rarely detected in samples of groundwater from the Edwards aquifer. Higher nitrate concentrations for samples from the shallow/urban unconfined groundwater category likely reflect a greater anthropogenically-derived influx of nitrate in the urban environment, which has a variety of potential nitrate sources, relative to samples collected from more rural unconfined groundwater category wells. A time-series record (1938-2006) of discharge at Comal Springs, one of the major aquifer discharge points, indicates an upward trend for nitrate and chloride concentrations, which likely reflects anthropogenic activities. A small number of organic contaminants were routinely or frequently detected in Edwards aquifer groundwater samples. These were the pesticides atrazine, its degradate deethylatrazine, and simazine; the drinking-water disinfection byproduct chloroform (a trihalomethane); and the solvent tetrachloroethene (commonly used in dry cleaning). Detection of these contaminants was most frequent in samples of the shallow/urban unconfined groundwater category and least frequent in samples of the unconfined groundwater category. These results indicate that the shallow/urban unconfined part of the aquifer is most affected by anthropogenic contaminants and that the urban environment is a source of contaminants to the aquifer. The unconfined part of the aquifer is the least affected by anthropogenic contaminants (these samples were mostly from undeveloped rural and rangeland areas). The high frequency of detection for these anthropogenic contaminants aquifer-wide and in samples of deep, confined groundwater indicate that the entire aquifer is susceptible to waterquality changes as a result of anthropogenic activities.

Changes in hydrologic conditions affect water quality. Samples of groundwater were collected one or two times during the study period (1996-2006) from most sites, a sampling frequency which does not allow for evaluation of temporal trends. Five of the shallow/urban unconfined category wells sampled by NAWQA had a higher frequency of sampling than other sites, with a total of eight samples collected over the 10-year study period. These data provide insights into the relation between changes in hydrologic conditions and changes in water quality. Relatively continuous or frequent periodic water-level altitude measurements for these five wells allow for comparison between geochemical variability and hydrologic conditions at each site. Time-series changes in three indicator constituents at these five wells (that is, constituents or ratios of constituents that are representative of water-quality concerns and geochemical processes) were compared to changes in hydrologic conditions as represented by water-level altitudes at wells and spring discharge at Comal Springs. Indicator constituents considered were nitrate, atrazine, and the magnesium to calcium molar ratio. A comparison of variations in indicator constituents to water-level altitude for the most responsive of the five shallow/urban unconfined wells demonstrates distinct changes in indicator constituents in response to changes in hydrologic conditions. Higher atrazine concentrations at this well correspond to peaks in water-level altitude during wetter hydrologic conditions, whereas higher nitrate concentrations and magnesium to calcium ratios occur in conjunction with low water-level altitudes during drier hydrologic conditions. These results indicate that atrazine enters the aquifer with surface-water recharge, whereas background nitrate concentrations in the aquifer are diluted by surface-water recharge. Analyses of surface water from in and near the recharge zone are consistent with these results, showing higher atrazine and lower nitrate concentrations in samples of surface water relative to groundwater.

Estimating the age of groundwater is useful for understanding selected aspects of hydrogeology, such as groundwater flow and mixing. Geochemical age tracers were measured on a majority of groundwater samples from the Edwards aquifer, some in combination (including tritium, chlorofluorocarbons, and sulfur hexafluoride). Results for apparent groundwater ages indicated that groundwater samples from the Edwards aquifer are dominated by young (that is, water recharged within approximately the past 50 years) and (or) 
modern water (in this report, samples with apparent ages that belong to the present day, that is within 10 years of the time and locality of sampling), with extensive groundwater mixing. These results are consistent with the regional hydrogeology and previous studies that document a range of travel times and groundwater mixing. Many of the chlorofluorocarbon and sulfur hexafluoride results indicated that samples were contaminated by non-atmospheric sources of these tracers. Apparent ages were not determined for samples with tracer contamination. Apparent ages for all uncontaminated groundwater samples ranged from about 1 to 52 years, with a median of 20 years. Apparent age interpretations are based on a pistonflow model, which assumes that the tracer concentration was not altered by transport processes. This approach might not adequately describe the range of ages in a mixed sample, which is a relevant consideration for karst aquifers such as the Edwards aquifer. In spite of uncertainties in age interpretation, piston-flow model ages provide an initial reference point for comparison of different age tracers and time scales of flow processes in the aquifer. Age tracers might not be well-suited to distinguish small differences in groundwater ages measured in samples collected from individual wells in the Edwards aquifer, but they provide insight into how changing hydrologic conditions affect groundwater recharge and mixing. Results indicate that variability in hydrologic conditions results in different mixtures of groundwater of different apparent ages. Apparent age results for samples collected from the relatively shallow unconfined part of the aquifer were younger than those for samples collected from the deeper unconfined part of the aquifer.

NAWQA studies in other aquifer systems have compared groundwater apparent age tracer results to estimates of flow rates and travel times from hydrogeologic models. Previously developed hydrogeologic models for the Edwards aquifer allow for a similar comparison. There is little agreement between the apparent groundwater ages estimated by the two approaches. These results indicated that existing flow models do not accurately represent the rapid, fast-flow (conduit-dominated) component of this karstic aquifer, which is a recognized limitation of applications of distributed porous media models to karst aquifer systems. Support of this conclusion is also demonstrated by results of dye-tracing tests in northern Bexar County that indicate groundwater velocities that are orders of magnitude higher than model results. The model results, however, do show a progression toward longer travel times from the unconfined to the confined parts of the aquifer, which is consistent with geochemical interpretations and aquifer hydrogeology.

Water-quality data for the San Antonio segment of the Edwards aquifer are useful for assessing the status of water quality and regional hydrologic processes that affect geochemistry. Analysis of temporal trends or evaluation of the relation between groundwater quality and hydrologic conditions is constrained by few time-series data. Collection of water-quality data at selected integrator sites (for example, for the Edwards aquifer, major discharge points such as Comal
Springs and carefully selected wells) on different time scales and associated with different hydrologic conditions would address multiple time scales of aquifer variability (from eventbased, short-term to intermediate and long-term) to allow for understanding of both aquifer hydrology and short- and long-term trends in water quality. When monitoring programs are intended to provide the data necessary to assess long-term trends and increase understanding of karst aquifer functioning, time scales of hydrologic and geochemical variability need to be carefully considered.

\section{References}

Abbott, P.L., 1975, On the hydrology of the Edwards Limestone, south-central Texas: Journal of Hydrology, v. 24, p. 251-269.

Abbott, P.L., and Woodruff, C.M., Jr., 1986, eds., The Balcones escarpment-Geology, hydrology, ecology and social development in central Texas: Geological Society of America.

Ashworth, J.B., and Hopkins, Janie, 1995, Major and minor aquifers of Texas: Texas Water Development Board Report 345, 60 p.

Atkinson, T.C., 1977, Diffuse flow and conduit flow in limestone terrain in the Mendip Hills, Somerset (Great Britain): Journal of Hydrology, v. 35, p. 93-110.

Baertschi, P., 1976, Absolute ${ }^{18} \mathrm{O}$ content of Standard Mean Ocean Water: Earth and Planetary Science Letters, v. 31, p. 341-344.

Banner, J.L., 2004, Radiogenic isotopes-Systematics and applications to earth surface processes and chemical stratigraphy: Earth Science Reviews, v. 65, p. 141-194.

Banner J.L., and Hanson, G.H., 1990, Calculation of simultaneous isotopic and trace-element variations during waterrock interactions with applications to carbonate diagenesis: Geochimica et Cosmochimica Acta, v. 54, p. 3,123-3,137.

Banner, J.L., Musgrove, M., and Capo, R.C., 1994, Tracing ground-water evolution in a limestone aquifer using $\mathrm{Sr}$ isotopes-Effects of multiple sources of dissolved ions and mineral-solution reactions: Geology, v. 22, p. 687-690.

Banner, J.L., Wasserburg, G.J., Dobson, P.F., Carpenter, A.B., and Moore, C.H., 1989, Isotopic and trace-element constraints on the origin and evolution of saline groundwaters from central Missouri: Geochimica et Cosmochimica Acta, v. 53, p. 383-398.

Barker, R.A., and Ardis, A.F., 1996, Hydrogeologic framework of the Edwards-Trinity aquifer system, west-central Texas: U.S. Geological Survey Professional Paper 1421-B, $61 \mathrm{p}$. 
Bethke, C.M., and Johnson, T.M., 2008, Groundwater age and groundwater age dating: Annual Reviews of Earth and Planetary Science, v. 36, p. 121-152.

Böhlke, J.K., 2006, Tracermodel 1. Excel workbook for calculation and presentation of environmental tracer data for simple groundwater mixtures, in Use of chlorofluorocarbons in hydrology-A guidebook, Section III.3: Vienna, Austria, International Atomic Energy Agency, STI/ PUB/1238, p. 239-243.

Burchett, C.R., Rettman, P.L., and Boning, C.W., 1986, The Edwards aquifer, extremely productive, but....A sole-source water supply for San Antonio and surrounding counties in south-central Texas: San Antonio, Edwards Underground Water District Report, 38 p.

Burrow, K.R., Jurgens, B.C., Kauffman, L.J., Phillips, S.P., Dalgish, B.A., and Shelton, J.L., 2008, Simulations of ground-water flow and particle pathline analysis in the zone of contribution of a public-supply well in Modesto, Eastern San Joaquin Valley, California: U.S Geological Survey Scientific Investigations Report 2008-5035, 41 p.

Busenberg, E., and Plummer, L.N., 1991, Chlorofluorocarbons $(\mathrm{CCl} 3 \mathrm{~F}$ and $\mathrm{CCl} 2 \mathrm{~F} 2)$ - Use as an age-dating tool and hydrologic tracer in shallow ground-water systems, in Mallard, G.E., and Aronson, D.A., eds., U.S. Geological Survey Toxic Substances Hydrology Program-Proceedings of the technical meeting, Monterey, California, March 11-15, 1991: U.S. Geological Survey Water-Resources Investigations Report 91-4034, p. 542-547.

Busenberg, E., and Plummer, L.N., 2000, Dating young ground water with sulfur hexafluoride-Natural and anthropogenic sources of $\mathrm{SF}_{6}$ : Water Resources Research, v. 36, p. 3,011-3,030.

Busenberg, E., and Plummer, L.N., 2008, Dating groundwater with trifluoromethyl sulfurpentafluoride $\left(\mathrm{SF}_{5} \mathrm{CF}_{3}\right)$, sulfur hexafluoride $\left(\mathrm{SF}_{6}\right), \mathrm{CF}_{3} \mathrm{Cl}(\mathrm{CFC}-13)$, and $\mathrm{CF}_{2} \mathrm{Cl}_{2}$ (CFC-12): Water Resources Research, v. 44, W02431, doi:10.1029/2007WR006150.

Bush, P.W., Ardis, A.F., Fahlquist, Lynne, Ging, P.B., Hornig, C.E., and Lanning-Rush, Jennifer, 2000, Water quality in south-central Texas, Texas, 1996-98: U.S. Geological Survey Circular 1212, $32 \mathrm{p}$.

Campana, M.E., and Mahin, D.A., 1985, Model-derived estimates of groundwater mean ages, recharge rates, effective porosities and storage in a limestone aquifer: Journal of Hydrology, v. 76, p. 247-264.

Childress, C.J., Oblinger, Foreman, W.T., Conner, B.F., and Maloney, T.J., 1999, New reporting procedures based on long-term method detection levels and some considerations for interpretations of water-quality data provided by the U.S. Geological Survey National Water Quality Laboratory: U.S. Geological Survey Open-File Report 99-193, 19 p.
Clark, A.K., and Journey, C.E., 2006, Flow paths in the Edwards aquifer, northern Medina and northeastern Uvalde Counties, Texas, based on hydrologic identification and geochemical characterization and simulation: U.S. Geological Survey Scientific Investigations Report 2006-5200, $48 \mathrm{p}$.

Clark, B.R., Landon, M.K., Kauffman, L.J., and Hornberger, G.Z., 2007, Simulations of ground-water flow, transport, age, and particle tracking near York, Nebraska, for a study of transport of anthropogenic and natural contaminants (TANC) to public-supply wells: U.S. Geological Survey Scientific Investigations Report 2007-5068, 48 p.

Clark, I.D., and Fritz, P., 1997, Environmental isotopes in hydrogeology: Boca Raton, Fla., Lewis Publishers, 328 p.

Clement, T.J., 1989, Hydrochemical facies of the badwater zone of the Edwards aquifer, central Texas: Austin, Tex., University of Texas at Austin, unpublished M.A. thesis, $168 \mathrm{p}$.

Clement, T.J., and Sharp, J.M., Jr., 1988, Hydrogeochemical facies in the bad-water zone of the Edwards aquifer, central Texas, in Ground Water Geochemistry Conference, Proceedings: Dublin, Ohio, National Water Well Association, p. 127-149.

Cook, P.G., and Böhlke, J.K., 2000, Determining timescales for groundwater flow and solute transport, in Cook, P.G., and Herczeg, A., eds., Environmental tracers in subsurface hydrology: Boston, Mass., Kluwer Academic Publishers, p. $1-30$.

Craig, Harmon, 1961, Isotopic variations in meteoric waters: Science, v. 133, p. 1,702-1,703.

Desmarais, K., and Rojstaczer, S., 2002, Inferring source waters from measurements of carbonate spring responses to storms: Journal of Hydrology, v. 260, p. 118-134.

Eckhardt, D.A., and Stackelberg, P.E., 1995, Relation of ground-water quality to land use on Long Island, New York: Ground Water, v. 33, p. 1,019-1,033.

Edwards Aquifer Authority, 2009, The Edwards aquiferAquifer levels: available at http://edwardsaquifer.org.

Edwards Aquifer Research and Data Center, 2010, Threatened and endangered species in the Edwards aquifer system: accessed January 29, 2010, at http://www.eardc.txstate.edu/ endangered.html.

Eisenlohr, L., and Surbeck, H., 1995, Radon as a natural tracer to study transport processes in a karst system-An example in the Swiss Jura: Comptes Rendus de l'Academie des Sciences, Serie II Fascicule A-Sciences de la Terre et des Planetes, v. 321, p. 761-767.

Ellis, P.M., 1985, Diagenesis of the Lower Cretaceous Edwards Group in the Balcones fault zone area, southcentral Texas: Austin, Tex., University of Texas at Austin, unpublished Ph.D. dissertation, 327 p. 
Fahlquist, Lynne, 2003, Ground-water quality of the southern High Plains aquifer, Texas and New Mexico, 2001: U.S. Geological Survey Open-File Report 03-345, 61 p.

Fahlquist, Lynne, and Ardis, A.F., 2004, Quality of water in the Trinity and Edwards aquifers, south-central Texas, 1996-98: U.S. Geological Survey Scientific Investigations Report 2004-5201, 17 p.

Fairchild, I.J., Borsato, A., Tooth, A.F., Frisia, S., Hawkesworth, C.J., Huang, H., McDermott, F., and Spiro, B., 2000, Controls on trace element ( $\mathrm{Sr}-\mathrm{Mg}$ ) compositions of carbonate cave waters-Implications for speleothem climatic records: Chemical Geology, v. 166, p. 255-269.

Fairchild, I.J., Tuckwell, G.W., Baker, A., and Tooth, A.F., 2006, Modelling of dripwater hydrology and hydrogeochemistry in a weakly karstified aquifer (Bath, UK) - Implications for climate change studies: Journal of Hydrology, v. 321, p. 213-231.

Falcone, R.A., Falgiani, A., Parisse, B., Petitta, M., Spizzico, M., and Tallini, M., 2008, Chemical and isotopic $\left(\delta^{18} \mathrm{O} \%\right.$, $\delta^{2} \mathrm{H} \%$ o, $\delta^{13} \mathrm{C} \%$ o, ${ }^{222} \mathrm{Rn}$ ) multi-tracing for groundwater conceptual model of carbonate aquifer (Gran Sasso INFN underground laboratory-central Italy): Journal of Hydrology, v. 357, p. 368-388.

Fallon, J.D., Tierney, D.P., and Thurman, E.M., 2002, Movement of atrazine and deethylatrazine through a Midwestern reservoir: Journal of the American Water Works Association, v. 94, no. 11, p. 54-66.

Fisher, W.L., and Rodda, P.U., 1969, Edwards Formation (Lower Cretaceous), Texas-Dolomitization in a carbonate platform system: The American Association of Petroleum Geologists Bulletin, v. 53, p. 55-72.

Friesen, B.A., Hester, D.J., and Casey, K., 2004, Edwards Plateau-Analysis of land cover trends, 2004, in International Geoscience and Remote Sensing Symposium (IGARRS), Anchorage, Alaska, Proceedings: v. 4, p. 2,639-2,642.

Fritz, P., and Fontes, J.-Ch., eds., 1980, Handbook of environmental isotope geochemistry, v. 1-The terrestrial environment: Amsterdam, Elsevier, 545 p.

Galloway, J.N., Townsend, A.R., Erisman, J.W., Bekunda, M., Cai, Z., Freney, J.R., Martinelli, L.A., Seitzinger, S.P., and Sutton, M.A., 2008, Transformation of the nitrogen cycleRecent trends, questions, and potential solutions: Science, v. 320, p. 889-892.

Garner, B.D., 2005, Geochemical evolution of ground water in the Barton Springs segment of the Edwards aquifer: Austin, Tex., University of Texas at Austin, M.S. thesis, 317 p.

Garner, B.D., and Mahler, B.J., 2007, Relation of specific conductance in ground water to intersection of flow paths by wells, and associated major ion and nitrate geochemistry,
Barton Springs segment of the Edwards aquifer, Austin, Texas, 1978-2003: U.S. Geological Survey Scientific Investigations Report 2007-5002, 171 p.

Gat, J.R., 1981, Groundwater, in Gat, J.R., and Gonfiantini, R., eds., Stable isotope hydrology-Deuterium and oxygen-18 in the water cycle: Vienna, Austria, International Atomic Energy Agency, p. 223-240.

Gilliom, R.J., Alley, W.M., and Gurtz, M.E., 1995, Design of the National Water-Quality Assessment Program-Occurrence and distribution of water-quality conditions: U.S. Geological Survey Circular 1112, 33 p.

Gilliom, R.J., Barbash, J.E., Crawford, C.G., Hamilton, P.A., Martin, J.D., Nakagaki, N., Nowell, L.H., Scott, J.C., Stackelberg, P.E., Thelin, G.P., and Wolock, D.M., 2006, Pesticides in the Nation's streams and ground water, 19922001: U.S. Geological Survey Circular 1291, 172 p.

Glynn, P.D., and Plummer, L.N., 2005, Geochemistry and the understanding of ground-water systems: Hydrogeology Journal, v. 13, p. 263-287.

Goldsmith, J.R., Graf, D.L., and Joensuu, O.I., 1955, The occurrence of magnesian calcites in nature: Geochimica et Cosmochimica Acta, v. 7, p. 212-228.

Griffiths, J.F., and Strauss, R.F., 1985, The variety of Texas weather: Weatherwise, v. 38, p. 137-141.

Groschen, G.E., and Buszka, P.M., 1997, Hydrogeologic framework and geochemistry of the Edwards aquifer salinewater zone, south-central Texas: U.S. Geological Survey Water-Resources Investigations Report 97-4133, 47 p.

Hagemann, R., Nief, G., and Roth, E., 1970, Absolute isotopic scale for deuterium analyses of natural waters-Absolute D/H ratio for SMOW: Tellus, v. 22, p. 712-715.

Hamilton, J.M., Johnson, S., Mireles, J., Esquilin, R., Burgoon, C., Luevano, G., Gregory, D., Gloyd, R., Sterzenback, J., Mendoza, R., and Schindel, G.M., 2008, Edwards aquifer Authority hydrogeologic data report for 2007: Edwards Aquifer Authority Report 08-02, 229 p.

Happell, J.D., Ospahl, S., Top, Z., and Chanton, J.P., 2006, Apparent $\mathrm{CFC}$ and ${ }_{3} \mathrm{H} /{ }_{3} \mathrm{He}$ age differences in water from Floridan aquifer springs: Journal of Hydrology, v. 319, p. 410-426.

Harbaugh, A.W., Banta, E.R., Hill, M.C., and McDonald, M.G., 2000, MODFLOW-2000, the U.S. Geological Survey modular ground-water model-Users guide to modularization concepts and the ground-water flow process: U.S. Geological Survey Open-File Report 00-92, 121 p.

Hauwert, N.M., Johns, D.A., Hunt, B.B., Beery, J., Smith, B.A., and Sharp, J.M., Jr., 2004, Flow systems of the Edwards aquifer Barton Springs segment interpreted 
from groundwater tracing and associated field studies, in Edwards water resources in Central Texas-Retrospective and prospective, South Texas Geological Society and Austin Geological Society symposium, San Antonio, Tex., May 21-24, 2004: 13 p.

Hauwert, N.M., Samson, J.W., Johns, D.A., and Aley, T.J., 2004, Groundwater tracing study of the Barton Springs segment of the Edwards aquifer, southern Travis and northern Hays Counties, Texas: Barton Springs/Edwards Aquifer Conservation District and City of Austin Watershed Protection and Development Review Department, 110 p., appendixes.

Hayes, T.B., 2004, There is no denying this-Defusing the confusion about atrazine: Bioscience, v. 54, p. 1,138-1,149.

Helsel, D.R., and Hirsch, R.M., 2002, Hydrologic analysis and interpretation-Statistical methods in water resources: U.S. Geological Survey Techniques of Water-Resources Investigations, book 4, chap. A3, accessed September 2008 at http://pubs.usgs.gov/twri/twri4a3/html/pdf_new.html.

Hem, J.D., 1989, Study and interpretation of the chemical characteristics of natural water ( $3 \mathrm{~d}$ ed.): U.S. Geological Survey Water-Supply Paper 2254, 264 p.

Hess, J.W., and White, W.B., 1993, Groundwater geochemistry of the carbonate karst aquifer, south-central Kentucky, U.S.A.: Applied Geochemistry, v. 8, p. 189-204.

Hoekstra, E.J., De Leer, E.W.B., and Brinkman, U.A.T., 1998, Natural formation of chloroform and brominated trihalomethanes in soil: Environmental Science and Technology, v. 32, p. 3,724-3,729.

Homer, C.G., Huang, C., Yang, L., Wylie, B.K., and Coan, M.J., 2001, National Land Cover Database 2001 (NLCD 2001): U.S. Geological Survey, EROS Data Center, MRLC Project, Sioux Falls, S. Dak., accessed October 2007 at http://seamless.usgs.gov/.

Honisch, M., Hellmeier, C., and Weiss, K., 2002, Response of surface and subsurface water quality to land use changes: Geoderma, v. 105, p. 277-298.

Hovorka, S.D., Dutton, A.R., Ruppel, S.C., and Yeh, J.S., 1996, Edwards aquifer ground-water resources-Geologic controls on porosity development in platform carbonates, South Texas: University of Texas at Austin, Bureau of Economic Geology Report of Investigations 238, 75 p.

Hunkeler, D., and Mudry, J., 2007, Hydrochemical methods, in Goldscheider, N., and Drew, D., eds., Methods in karst hydrogeology: International Association of Hydrogeologists, p. 93-122.

International Atomic Energy Agency, 2006, Use of chlorofluorocarbons in hydrology-A guidebook: Vienna, Austria, International Atomic Energy Agency, 227 p.
Johnson, S.B., and Schindel, G.M., 2008, Evaluation of the option to designate a separate San Marcos pool for critical period management: San Antonio, Tex., Edwards Aquifer Authority, 109 p.

Johnson, S.B., Schindel, G.M., and Veni, G., 2009, Tracing groundwater flowpaths in the Edwards aquifer recharge zone, Panther Springs Creek Basin, northern Bexar County, Texas, USA, in 15th International Congress of Speleology, Kerrville, Texas, July 19-26, 2009, Proceedings: p. 1,538.

Jones, B.D., 1991, Texas-Floods and droughts, in Paulson, R.W., Chase, E.B., Roberts, R.S., and Moody, D.W., compilers, National water summary 1988-89-Hydrologic events and floods and droughts: U.S. Geological Survey Water-Supply Paper 2375, p. 513-520.

Jones, I.C., Banner, J.L., and Humphrey, J.D., 2000, Estimating recharge in a tropical karst aquifer: Water Resources Research, v. 36, p. 1,289-1,299.

Jurgens, B.C., Burow, K.R., Dalgish, B.A., and Shelton, J.L., 2008, Hydogeology, water chemistry, and factors affecting the transport of contaminants in the zone of contribution of a public-supply well in Modesto, Eastern San Joaquin Valley, California: U.S Geological Survey Scientific Investigations Report 2008-5156, 78 p.

Karst Waters Institute, 2008, What is karst (and why is it important)?: accessed June 26, 2008, at http://www. karstwaters.org/kwitour/whatiskarst.htm.

Katz, B.G., Böhlke, J.K., and Hornsby, H.D., 2001, Timescales for nitrate contamination of spring waters, northern Florida, USA: Chemical Geology, v. 179, p. 167-186.

Kendall, C., and McDonnell, J.J., eds., 1998, Isotope tracers in catchment hydrology: New York, Elsevier, 839 p.

Klemt, W.B., Knowles, T.R., Edler, G.R., and Sieh, T.W., 1979, Ground-water resources and model applications for the Edwards (Balcones fault zone) aquifer in the San Antonio region: Texas Water Development Board Report 239, 88 p.

Koepnick, R.B., Burke, W.H., Denison, R.E., Hetherington, E.A., Nelson, H.F., Otto, J.B., and Waite, L.E., 1985, Construction of the seawater ${ }^{87} \mathrm{Sr} /{ }^{86} \mathrm{Sr}$ curve for the Cenozoic and Cretaceous-Supporting data: Chemical Geology (Isotope Geoscience Section), v. 58, p. 55-81.

Kostick, D.S., Milanovich, J.A., and Coleman, R.R., 2007, 2005 Minerals yearbook-Salt: U.S. Geological Survey, accessed July 27, 2009, at http://minerals.er.usgs.gov/ minerals/pubs/commodity/salt/salt_myb05.pdf.

Koterba, M.T., 1998, Ground-water data-collection protocols and procedures for the National Water-Quality Assessment Program-Collection, documentation, and compilation of required site, well, subsurface, and landscape data for wells: 
U.S. Geological Survey Water-Resources Investigations Report 98-4107, 91 p.

Koterba, M.T., Wilde, F.T., and Lapham, W.W., 1995, Groundwater data-collection protocols and procedures for the National Water-Quality Assessment Program-Collection and documentation of water-quality samples and related data: U.S. Geological Survey Open-File Report 95-399, $133 \mathrm{p}$.

Lakey, B., and Krothe, N.C., 1996, Stable isotopic variation of storm discharge from a perennial karst spring: Water Resources Research, v. 32, p. 721-731.

Lambert, R.B., Hunt, A.G., Stanton, G.P., and Nyman, M.B., 2009, Water-level, borehole geophysical log, and waterquality data from wells transecting the freshwater/salinewater interface of the San Antonio segment of the Edwards aquifer, south-central Texas, 1999-2007: U.S. Geological Survey Data Series 403 [variously paged] available at http://pubs.usgs.gov/ds/403/.

Landon, M.K., Clark, B.R., McMahon, P.B., McGuire, V.L., and Turco, M.J., 2008, Hydrogeology, chemical characteristics, and transport processes in the zone of contribution of a public-supply well in York, Nebraska: U.S Geological Survey Scientific Investigations Report 2008-5050, 149 p.

Landon, M.K., Jurgens, B.C., Katz, B.G., Eberts, S.M., Burow, K.R., and Crandall, C.A., 2009, Depth-dependent sampling to identify short-circuit pathways to public-supply wells in multiple aquifer settings in the United States: Hydrogeology Journal, DOI 10.1007/s10040-009-0531-2.

Lapham, W.W., Wilde, F.D., and Koterba, M.T., 1995, Ground-water data-collection protocols and procedures for the National Water-Quality Assessment Program-Selection, installation, and documentation of wells, and collection of related data: U.S. Geological Survey Open-File Report 95-398, 69 p.

Lawrence, J.R., 1998, Isotopic spikes from tropical cyclones in surface waters-Opportunities in hydrology and paleoclimatology: Chemical Geology, v. 144, p. 153-160.

Lawrence, J.R., and Gedzelman, S.D., 1996, Low stable isotope ratios of tropical cyclone rains: Geophysical Research Letters, v. 23, p. 527-530.

Lindgren, R.J., 2006, Diffuse-flow conceptualization and simulation of the Edwards aquifer, San Antonio region, Texas: U.S. Geological Survey Scientific Investigations Report 2006-5319, 48 p.

Lindgren, R.J., Dutton, A.R., Hovorka, S.D., Worthington, S.R.H., and Painter, Scott, 2004, Conceptualization and simulation of the Edwards aquifer, San Antonio region, Texas: U.S. Geological Survey Scientific Investigations Report 2004-5277, 143 p.
Lohmann, K.C., 1988, Geochemical patterns of meteoric diagenetic systems and their application to studies of paleokarst, in James, N.P., and Choquette, P.W., eds., Paleokarst: New York, Springer-Verlag, p. 58-80.

Long, A.J., and Putnam, L.D., 2006, Translating CFCbased piston ages into probability density functions of ground-water age in karst: Journal of Hydrology, v. 330, p. 735-747.

Maclay, R.W., 1995, Geology and hydrology of the Edwards aquifer in the San Antonio area, Texas: U.S. Geological Survey Water-Resources Investigations Report 95-4186, $64 \mathrm{p}$.

Maclay, R.W., and Land, L.F., 1988, Simulation of flow in the Edwards aquifer, San Antonio region, Texas, and refinements of storage and flow concepts: U.S. Geological Survey Water-Supply Paper 2336-A, 48 p.

Maclay, R.W., and Small, T.A., 1983, Hydrostratigraphic subdivisions and fault barriers of the Edwards aquifer, south-central Texas, U.S.A.: Journal of Hydrology, v. 61, p. $127-146$.

Maclay, R.W., and Small, T.A., 1986, Carbonate geology and hydrology of the Edwards aquifer in the San Antonio area, Texas: Texas Water Development Board Report 296, $90 \mathrm{p}$.

Mahler, B.J., 2008, Statistical analysis of major ion and trace element geochemistry of water, 1986-2006, at seven wells transecting the freshwater/saline-water interface of the Edwards aquifer, San Antonio, Texas: U.S. Geological Survey Scientific Investigations Report 2008-5224, 46 p.

Mahler, B.J., and Garner, B.D., 2009, Using nitrate to quantify quick flow in a karst aquifer: Ground Water, v. 47, p. 350-360.

Mahler, B.J., Garner, B.D., Musgrove, M., Guilfoyle, A.L., and Rao, M.V., 2006, Recent (2003-05) water quality of Barton Springs, Austin, Texas, with emphasis on factors affecting variability: U.S. Geological Survey Scientific Investigations Report 2006-5299, 83 p., 5 appendixes.

Mahler, B.J., and Massei, Nicolas, 2007, Anthropogenic contaminants as tracers in an urbanizing karst aquifer: Journal of Contaminant Hydrology, v. 91, p. 81-106.

Majewski, M.S., and Capel, P.D., 1995, Pesticides in the atmosphere-Distribution, trends, and governing factors: Chelsea, Mich., Ann Arbor Press, Inc., p. 78-80.

Maloszewski, P., Stichler, W., Zuber, A., and Rank, D., 2002, Identifying the flow systems in a karstic-fissured-porous aquifer, the Schneealpe, Austria, by modeling of environmental ${ }^{18} \mathrm{O}$ and ${ }^{3} \mathrm{H}$ isotopes: Journal of Hydrology, v. 256, p. $48-59$. 
McCulloch, A., 2003, Chloroform in the environmentOccurrence, sources, sinks, and effects: Chemosphere, v. 50, p. 1,291-1,308.

McMahon, P.B., Böhlke, J.K., Kauffman, L.J., Kipp, K.L., Landon, M.K., Crandall, C.A., Burow, K.R., and Brown, C.J., 2008, Source and transport controls on the movement of nitrate to public supply wells in selected principal aquifers of the United States: Water Resources Research, v. 44, W04401, doi:10.1029/2007WR006252.

McMahon, P.B., Cowdery, T.K., Chapelle, F.H., and Jurgens, B.C., 2009, Redox conditions in selected principal aquifers of the United States: U.S. Geological Survey Fact Sheet 2009-3041, 6 p.

McNutt, R.H., Frape, S.K., Fritz, P., Jones, M.G., and MacDonald, I.M., 1990, The ${ }^{87} \mathrm{Sr} /{ }^{86} \mathrm{Sr}$ values of Canadian Shield brines and fracture minerals with applications to groundwater mixing, fracture history, and geochronology: Geochimica et Cosmochimica Acta, v. 54, p. 205-215.

Michel, R.L., 1989, Tritium deposition in the continental United States, 1953-83: U.S. Geological Survey WaterResources Investigations Report 89-4072, 46 p.

Moran, M.J., Lapham, W.W., Rowe, B.L., and Zogorski, J.S., 2002, Occurrence and status of volatile organic compounds in ground water from rural, untreated, self-supplied domestic wells in the United States, 1986-99: U.S. Geological Survey Water-Resources Investigations Report 02-4085, $51 \mathrm{p}$.

Musgrove, M., 2000, Temporal links between climate and hydrology-Insights from central Texas cave deposits and groundwater: Austin, Tex., University of Texas at Austin, unpublished Ph.D. dissertation, $432 \mathrm{p}$.

Musgrove, M., and Banner, J.L., 1993, Regional ground-water mixing and the origin of saline fluids-Midcontinent, United States: Science, v. 259, p. 1,877-1,882.

Musgrove, M., and Banner, J.L., 2004, Controls on the spatial and temporal variability of vadose dripwater geochemistry-Edwards aquifer, central Texas: Geochimica et Cosmochimica Acta, v. 68, p. 1,007-1,020.

National Oceanic and Atmospheric Administration, 2009, National Climatic Data Center-Climatological data, San Antonio International Airport, San Antonio, Texas, cooperative station identifier 417945: accessed at http://www.ncdc. noaa.gov/oa/ncdc.html.

Ockerman, D.J., 2005, Simulation of streamflow and estimation of recharge to the Edwards aquifer in the Hondo Creek, Verde Creek, and San Geronimo Creek watersheds, southcentral Texas, 1951-2003: U.S. Geological Survey Scientific Investigations Report 2005-5252, 37 p.

Oetting, G.C., 1995, Evolution of fresh and saline groundwaters in the Edwards aquifer-Geochemical and $\mathrm{Sr}$ isotopic evidence for regional fluid mixing and fluid-rock interaction: Austin, Tex., University of Texas at Austin, unpublished M.A. thesis, 204 p.

Oetting, G.C., Banner, J.L., and Sharp, J.M., Jr., 1996, Geochemical evolution of saline groundwaters in the Edwards aquifer, central Texas-Regional stratigraphic, tectonic, and hydrodynamic controls: Journal of Hydrology, v. 181, p. 251-283.

Ogden, A.E., Quick, R.A., and Rothermel, S.R., 1986, Hydrochemistry of the Comal, Hueco, and San Marcos Springs, Edwards aquifer, Texas, in Abbott, P.L., and Woodruff, C.M., Jr., eds., The Balcones escarpment-Geology, hydrology, ecology and social development in central Texas: Geological Society of America, p. 115-130.

Panno, S.V., Hackley, K.C., Hwang, H.H., Greenberg, S.E., Capac, I.R., Landsbergis, S., and O'Kelly, D.J., 2006, Characterization and identification of $\mathrm{Na}-\mathrm{Cl}$ sources in ground water: Ground Water, v. 44, p. 176-187.

Parkhurst, D.L., 1995, User's guide to PHREEQC-A computer program for speciation, reaction-path, advectivetransport, and inverse geochemical calculations: U.S. Geological Survey Water-Resources Investigations Report 95-4227, 143 p.

Pearson, F.J., Jr., and Rettman, P.L., 1976, Geochemical and isotopic analyses of waters associated with the Edwards Limestone aquifer, central Texas: U.S. Geological Survey Open-File Report, 35 p.

Pearson, F.J., Jr., Rettman, P.L., and Wyerman, T.A., 1975, Environmental tritium in the Edwards aquifer, central Texas, 1963-71: U.S. Geological Survey Open-File Report 74-362, $32 \mathrm{p}$.

Peterson, E.W., Davis, R.K., Brahana, J.V., and Orndorff, H.A., 2002, Movement of nitrate through regolith covered karst terrane, northwest Arkansas: Journal of Hydrology, v. 256, p. 35-47.

Petta, T.J., 1977, Diagenesis and geochemistry of a Glen Rose patch reef complex, Bandera County, Texas, in Bebout, D.G., and Loucks, R.G., eds., Cretaceous carbonates of Texas and Mexico-Applications to subsurface exploration: University of Texas at Austin, Bureau of Economic Geology Report of Investigations 89, p. 138-167.

Phillips, F.M., and Castro, M.C., 2003, Groundwater dating and residence-time measurements, in Holland, H.D., and Turekian, K.K., eds., Treatise on geochemistry-v. 5, Surface and ground water, weathering, and soils (Drever, J.I., ed.): Oxford, Oxford University Press, p. 451-497.

Plummer, L.N., 1977, Defining reactions and mass transfer in part of the Floridan aquifer: Water Resources Research, v. 13 , p. $801-812$. 
Plummer, L.N., 2005, Dating of young groundwater, in Aggarwal, P.K., Gat, J.R., and Froelich, K.F.O., eds., Isotopes in the water cycle-Past, present, and future of a developing science: Dordrecht, Netherlands, Springer, p. 193-220.

Plummer, L.N., and Busenberg, E., 2005, Chlorofluorocarbons background, in Cook, P.G., and Herczeg, A., eds., Environmental tracers in subsurface hydrology: Boston, Mass., Kluwer Academic Publishers, 552 p., accessed July 22, 2009, at http://water.usgs.gov/lab/chlorofluorocarbons/ background/.

Plummer, L.N., and Friedman, L.C., 1999, Tracing and dating young ground water: U.S. Geological Survey Fact Sheet 134-99, 4 p.

Plummer, L.N., Michel, R.L., Thurman, E.M., and Glynn, P.D., 1993, Environmental tracers for age-dating young ground water, in Alley, W.M., ed., Regional ground-water quality-Chapter 11: Van Nostrand Reinhold, p. 255-294.

Pollock, D.W., 1994, Source code and ancillary data files for the MODPATH particle tracking package of the groundwater flow model MODFLOW, version 3, release 1: U.S. Geological Survey Open-File Report 94-0463, 6 p., 2 CDs.

Quinlan, J.F., 1989, Ground-water monitoring in karst terranes, recommended protocols and implicit assumptions: U.S. Environmental Protection Agency, EPA/600/X-89/050.

Quinlan, J.F., and Ewers, R.O., 1989, Subsurface drainage in the Mammoth Cave area, in White, W.B., and White, E.L., eds., Karst hydrology - Concepts from the Mammoth Cave area: New York, Van Nostrand Reinhold, p. 65-103.

Rose, P.R., 1972, Edwards Group, surface and subsurface, central Texas: University of Texas, Bureau of Economic Geology Report of Investigations 74, 197 p.

Rudolph, J., Khedim, A., Koppmann, R., and Bonsang, B., 1995, Field-study of the emissions of methyl-chloride and other halocarbons from biomass burning in western Africa: Journal of Atmospheric Chemistry, v. 22, p. 67-80.

Rudolph, J., von Czapiewski, K., and Koppmann, R., 2000, Emissions of methyl chloroform $\left(\mathrm{CH}_{3} \mathrm{CCl}_{3}\right)$ from biomass burning and the tropospheric methyl chloroform budget: Geophysical Research Letters, v. 27, p. 1,887-1,890.

Sandstrom, M.W., Stroppel, M.E., Foreman, W.T., and Schroeder, M.P., 2001, Methods of analysis by the U.S. Geological Survey National Water Quality LaboratoryDetermination of moderate-use pesticides and selected degradates in water by $\mathrm{C}-18$ solid-phase extraction and gas chromatography/mass spectrometry: U.S. Geological Survey Water-Resources Investigations Report 01-4098, 70 p.

Schlesinger, W.H., Reckhow, K.H., and Bernhardt, E.S., 2006, Global change-The nitrogen cycle and rivers: Water Resources Research, v. 42, W03S06, doi:10.1029/2005WR004300.

Schultz, A.L., 1994, 1994 review and update of the position of the Edwards aquifer freshwater/saline-water interface from Uvalde to Kyle, Texas: Edwards Underground Water District Report 94-05, 31 p.

Schuster, E.T., and White, W.B., 1971, Seasonal fluctuations in the chemistry of limestone springs-A possible means for characterizing carbonate aquifers: Journal of Hydrology, v. 14, p. $93-128$.

Sharp, J.M., Jr., 1990, Stratigraphic, geomorphic and structural controls of the Edwards aquifer, Texas, U.S.A., in Simpson, E.S., and Sharp, J.M., Jr., eds., International Association of Hydrogeologists, Selected Papers from the 28th International Geological Congress, Washington, D.C., July 9-19, 1989: Heise, Hannover, v. 1, p. 67-82.

Sharp, J.M., Jr., and Banner, J.L., 1997, The Edwards aquifer-A resource in conflict: Geological Society of America (GSA) Today, v. 7, p. 1-9.

Sharp, J.M., Jr., and Clement, T.J., 1988, Hydrochemical facies as hydraulic boundaries in karstic aquifers-The Edwards aquifer, U.S.A., in Daoxian Y., ed., 21st International Association of Hydrologists Congress, Karst hydrogeology and karst environmental protection, Guilin, China, Proceedings: Beijing, China, Geological Publishing House, p. 841-845.

Simpson, I.J., Blake, N.J., Blake, D.R., Meinardi, S., Anderson, M.P.S., and Rowland, F.S., 2007, Strong evidence for negligible methyl chloroform $\left(\mathrm{CH}_{3} \mathrm{CCl}_{3}\right)$ emissions from biomass burning: Geophysical Research Letters, v. 35, L10805, doi:10.1029/2007GL029383.

Slade, R.M., Jr., 1986, Large rainstorms along the Balcones escarpment in central Texas, in Abbott, P.L., and Woodruff, C.M., Jr., eds., The Balcones escarpment-Geology, hydrology, ecology and social development in central Texas: Geological Society of America, p. 15-19.

Squillace, P.J., and Price, C.V., 1996, Urban land-use study plan for the National Water-Quality Assessment Program: U.S. Geological Survey Open-File Report 96-217, 19 p.

Surbeck, H., and Medici, F., 1991, Rn-222 transport from soil to karst caves by percolating water, in 22nd International Association of Hydrologists Congress, Lausanne, Switzerland, August 27-September 1, 1990, Proceedings: Memoires, v. 22, part 1, p. 348-355.

Texas General Land Office, 1999, County boundaries: 1:24,000, available at http://www.glo.state.tx.us/gisdata/ gisdata.html.

Texas Natural Resources Information System, 1995, City boundaries: available at http://www.tnris.state.tx.us/ datadownload/download.jsp. 
Texas State Historical Association, 2009, The handbook of Texas online-Droughts: available at http://www.tshaonline. org/handbook/online/articles/DD/ybdl.html.

Thompson, G.M., and Hayes, J.M., 1979, Trichlorofluoromethane in groundwater-A possible tracer and indicator of groundwater age: Water Resources Research, v. 14, no. 3, p. $546-554$.

Thorkildsen, D.F., and McElhaney, P.D., 1992, Model refinement and applications for the Edwards (Balcones fault zone) aquifer in the San Antonio region, Texas: Texas Water Development Board Report 340, 33 p.

Trudgill, S.T., Laidlaw, I.M.S., and Smart, P.L., 1980, Soil water residence times and solute uptake on a dolomite bedrock-Preliminary results: Earth Surface Processes, v. 5, p. 91-100.

U.S. Census Bureau, 2009, Population estimates: accessed April 7, 2009, at http://www.census.gov/acs/www/popest/ cities/tables/SUB-EST2007-01.xls.

U.S. Environmental Protection Agency, 2006, Region 6 water programs-Designated sole source aquifers: available at http://www.epa.gov/region6/water/swp/ssa/maps.htm.

U.S. Geological Survey, 2009, National Water Information System (NWIS) [for Texas] data: available at http://waterdata.usgs.gov/tx/nwis/nwis.

U.S. Geological Survey, variously dated, National field manual for the collection of water-quality data: U.S. Geological Survey Techniques of Water-Resources Investigations, book 9, chaps. A1-A9, available at http://pubs.water.usgs.gov/ twri9A.

Unterweger, M.P., Coursey, B.M., Schima, F.J., and Mann, W.B., 1980, Preparation and calibration of the 1978 National Bureau of Standards tritiated-water standards: International Journal of Applied Radiation and Isotopes, v. 31, p. $611-614$.

Vesper, D.J., and White, W.B., 2004, Storm pulse chemographs of saturation index and carbon dioxide pressureImplications for shifting recharge sources during storm events in the karst aquifer at Fort Campbell, Kentucky/ Tennessee, USA: Hydrogeology Journal, v. 12, p. 135-143.
Welhan, J.A., 1987, Stable isotope hydrology, in Kyser, T.K., ed., Short course in stable isotope geochemistry of low temperature fluids: Mineralogical Association of Canada, v. 13, p. 129-161.

White, W.B., 1988, Geomorphology and hydrology of karst terrains: New York, Oxford University Press, 464 p.

White, W.B., 2002, Karst hydrology_Recent developments and open questions: Engineering Geology, v. 65, p. 85-105.

Winston, W.E., and Criss, R.E., 2004, Dynamic hydrologic and geochemical response in a perennial karst spring: Water Resources Research, v. 40, W05106, doi:10.1029/2004WR003054.

Wong, C., 2008, Geochemical evolution of karst vadose water and brush clearing impacts on recharge in central Texas: Austin, Tex., University of Texas at Austin, unpublished M.S. thesis, $182 \mathrm{p}$.

Wong, C., Banner, J.L., Musgrove, M., and Mihealsick, C.A., 2007, Controls on the geochemical evolution of vadose water in a karst terrain in central Texas: Geological Society of America, Abstracts with Programs 39, 481.

Woodruff, C.M., Jr., and Abbott, P.L., 1979, Drainage-basin evolution and aquifer development in karstic limestone terrain, south-central Texas, U.S.A.: Earth Surface Processes, v. 4, p. 319-334.

Worthington, S.R.H., 2003, A comprehensive strategy for understanding flow in carbonate aquifers: Sepelogenesis and Evolution of Karst Aquifers, v. 1, p. 1-8.

Zaugg, S.D., and Leiker, T.J., 2006, Review of method performance and improvements for determining wastewater compounds (schedule 1433): U.S. Geological Survey National Water Quality Laboratory Technical Memorandum 2006.1 [variously paged].

Zogorski, J.S., Carter, J.M., Ivahnenko, T., Lapham, W.W., Moran, M.J., Rowe, B.L., Squillace, P.J., and Toccalino, P.L., 2006, The quality of our Nation's water-Volatile organic compounds in the Nation's ground water and drinking-water supply wells: U.S. Geological Survey Circu$\operatorname{lar} 1292,101 \mathrm{p}$. 
Table 3. Summary statistics by group for field, physicochemical, inorganic, radiogenic, and stable isotope constituents analyzed in groundwater samples collected from the San Antonio segment of the Edwards aquifer, south-central Texas, $1996-2006$.

[Statistics shown for all samples and for sample categories (shallow/urban unconfined, unconfined, and confined). ft, feet; NAVD 1988, North American Vertical Datum of 1988; NTRU, nephelometric turbidity ratiometric unit; $\mathrm{mmHg}$, millimeters mercury; $\mathrm{mg} / \mathrm{L}$, milligrams per liter; $\mu \mathrm{S} / \mathrm{cm}$, microsiemens per centimeter; ${ }^{\circ} \mathrm{C}$, degrees Celsius; $\mathrm{CaCO}_{3}$, calcium carbonate; <, nondetection less than laboratory reporting level; SI, saturation index; $\mathrm{Mg}$, magnesium; Ca, calcium; Sr, strontium; $\mathrm{N}$, nitrogen; $\mathrm{P}$, phosphorus; $\mu \mathrm{g} / \mathrm{L}$, micrograms per liter; $\delta^{18} \mathrm{O}$, delta oxygen- $18 ; \delta \mathrm{D}$, delta deuterium; $\delta^{13} \mathrm{C}$, delta carbon- $13 ;{ }^{87} \mathrm{Sr} /{ }^{86} \mathrm{Sr}$, strontium-87/ strontium-86; pCi/L, picocuries per liter; TU, tritium unit; --, not analyzed]

\begin{tabular}{|c|c|c|c|c|c|c|c|}
\hline \multirow[b]{2}{*}{ Constituent } & \multicolumn{7}{|c|}{ All } \\
\hline & $\begin{array}{l}\text { Number of } \\
\text { samples }\end{array}$ & $\begin{array}{l}\text { Number of } \\
\text { detections }\end{array}$ & Minimum & $\begin{array}{c}\text { 25th } \\
\text { percentile }\end{array}$ & Median & $\begin{array}{c}\text { 75th } \\
\text { percentile }\end{array}$ & Maximum \\
\hline \multicolumn{8}{|c|}{ Field and physicochemical properties } \\
\hline $\begin{array}{l}\text { Land-surface altitude, ft above NAVD } \\
\quad 1988\end{array}$ & 136 & 136 & 600 & 771 & 905 & 998 & 1,242 \\
\hline $\begin{array}{l}\text { Depth to bottom of open or screened } \\
\text { interval, ft from land surface }\end{array}$ & 136 & 113 & 80.0 & 280 & 485 & 1,040 & 2,700 \\
\hline Depth to water, ft below land surface & 108 & 108 & 22.5 & 148 & 196 & 223 & 353 \\
\hline Turbidity, NTRU & 216 & 216 & .03 & .21 & .49 & 1.44 & 81.0 \\
\hline Specific conductance, $\mu \mathrm{S} / \mathrm{cm}$ at $25^{\circ} \mathrm{C}$ & 250 & 250 & 377 & 495 & 551 & 600 & 1,199 \\
\hline Water temperature, ${ }^{\circ} \mathrm{C}$ & 249 & 249 & 21.1 & 22.8 & 23.5 & 24.3 & 32.5 \\
\hline Alkalinity, $\mathrm{mg} / \mathrm{L}$ as $\mathrm{CaCO}_{3}$ & 246 & 246 & 121 & 208 & 245 & 276 & 377 \\
\hline $\begin{array}{l}\text { Dissolved solids (residue on evaporation, } \\
\text { dried at } 180^{\circ} \mathrm{C} \text { ), } \mathrm{mg} / \mathrm{L}\end{array}$ & 239 & 239 & 201 & 283 & 313 & 343 & 3,852 \\
\hline \multicolumn{8}{|c|}{ Major ions and selected saturation indexes and ion ratios } \\
\hline Calcium, mg/L & 243 & 243 & 50.3 & 71.5 & 89.6 & 103 & 153 \\
\hline Magnesium, mg/L & 243 & 243 & 1.47 & 7.89 & 11.6 & 15.6 & 31.1 \\
\hline Potassium, mg/L & 243 & 243 & .43 & .85 & 1.03 & 1.22 & 2.93 \\
\hline Sodium, mg/L & 242 & 242 & 2.92 & 5.81 & 7.28 & 10.0 & 55.4 \\
\hline SI calcite & 240 & 240 & -.69 & -.20 & -.12 & -.03 & .43 \\
\hline SI dolomite & 240 & 240 & -2.42 & -1.09 & -.83 & -.51 & .23 \\
\hline SI gypsum & 240 & 240 & -2.96 & -2.48 & -2.36 & -2.21 & -1.49 \\
\hline $\mathrm{Mg} / \mathrm{Ca}$, molar ratio & 240 & 240 & .02 & .13 & .22 & .35 & .79 \\
\hline $\mathrm{Sr} / \mathrm{Ca}$, molar ratio $\left(\times 10^{3}\right)$ & 230 & 230 & .17 & .64 & 1.31 & 2.28 & 60.0 \\
\hline \multicolumn{8}{|c|}{ Nutrients } \\
\hline Nitrate plus nitrite, $\mathrm{mg} / \mathrm{L}$ as $\mathrm{N}$ & 243 & 241 & $<.05$ & 1.13 & 1.66 & 2.11 & 8.23 \\
\hline Nitrate, $\mathrm{mg} / \mathrm{L}$ as $\mathrm{N}$ & 240 & 238 & $<.05$ & 1.13 & 1.67 & 2.12 & 8.23 \\
\hline Ammonia, mg/L as $\mathrm{N}$ & 243 & 80 & $<.010$ & $<.02$ & $<.04$ & .008 & .102 \\
\hline Nitrite, $\mathrm{mg} / \mathrm{L}$ as $\mathrm{N}$ & 243 & 21 & $<.002$ & $<.006$ & $<.008$ & $<.01$ & .060 \\
\hline Orthophosphate, $\mathrm{mg} / \mathrm{L}$ as $\mathrm{P}$ & 243 & 167 & $<.01$ & $<.01$ & .009 & .014 & .030 \\
\hline Phosphorus, mg/L & 119 & 27 & $<.004$ & $<.01$ & $<.01$ & $<.05$ & .208 \\
\hline Organic carbon, mg/L & 191 & 191 & .20 & .30 & .40 & .51 & 15.6 \\
\hline
\end{tabular}


Table 3. Summary statistics by group for field, physicochemical, inorganic, radiogenic, and stable isotope constituents analyzed in groundwater samples collected from the San Antonio segment of the Edwards aquifer, south-central Texas, 1996-2006-Continued.

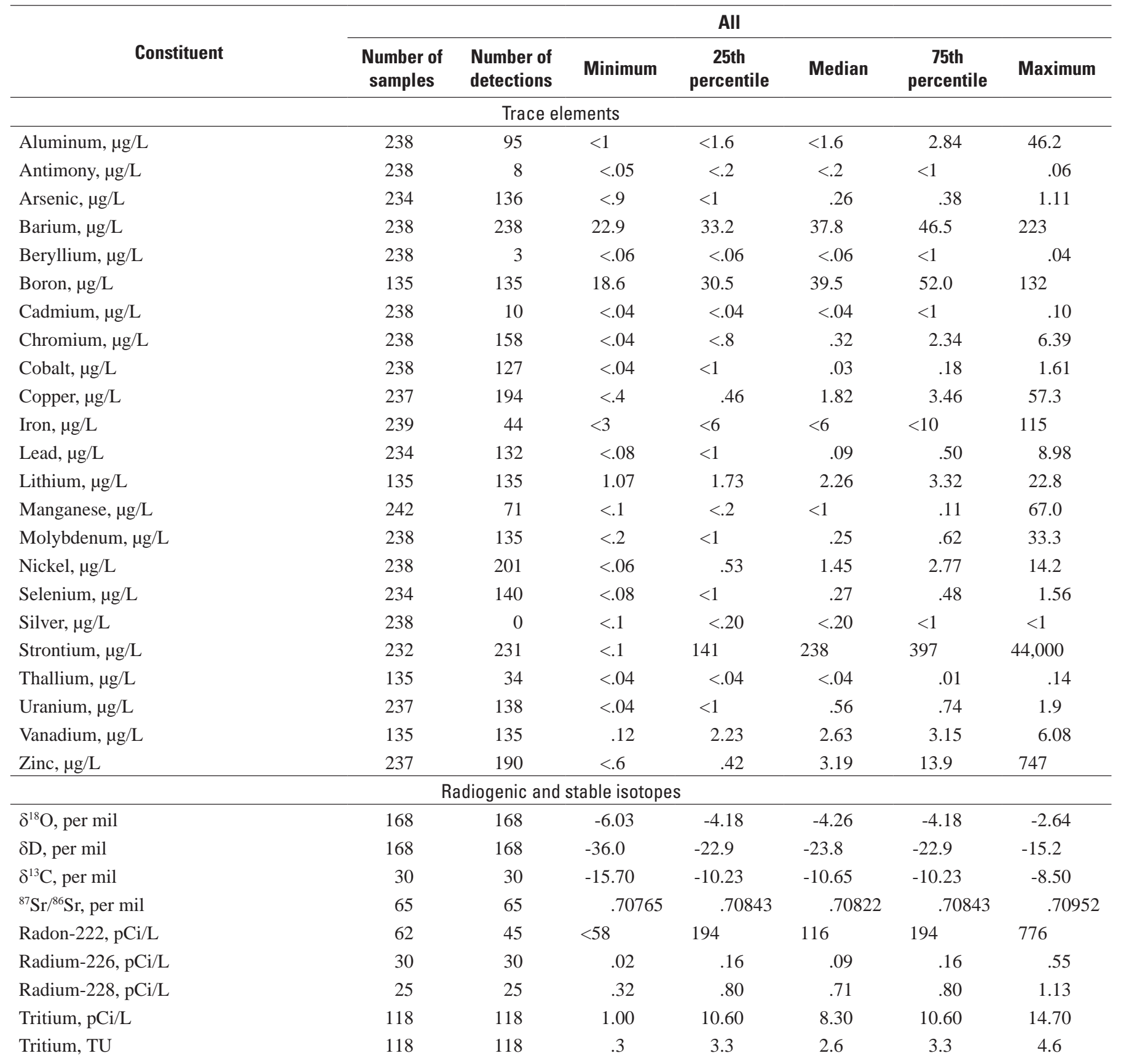


Table 3. Summary statistics by group for field, physicochemical, inorganic, radiogenic, and stable isotope constituents analyzed in groundwater samples collected from the San Antonio segment of the Edwards aquifer, south-central Texas, 1996-2006 —Continued.

\begin{tabular}{|c|c|c|c|c|c|c|c|}
\hline \multirow[b]{2}{*}{ Constituent } & \multicolumn{7}{|c|}{ Shallow/urban unconfined } \\
\hline & $\begin{array}{l}\text { Number of } \\
\text { samples }\end{array}$ & $\begin{array}{l}\text { Number of } \\
\text { detections }\end{array}$ & Minimum & $\begin{array}{c}\text { 25th } \\
\text { percentile }\end{array}$ & Median & $\begin{array}{c}\text { 75th } \\
\text { percentile }\end{array}$ & Maximum \\
\hline \multicolumn{8}{|c|}{ Field and physicochemical properties } \\
\hline $\begin{array}{l}\text { Land-surface altitude, ft above NAVD } \\
\quad 1988\end{array}$ & 30 & 30 & 803 & 891 & 936 & 973 & 1,015 \\
\hline $\begin{array}{l}\text { Depth to bottom of open or screened } \\
\text { interval, ft from land surface }\end{array}$ & 30 & 30 & 180 & 244 & 261 & 295 & 320 \\
\hline Depth to water, ft below land surface & 90 & 90 & 105 & 162 & 196 & 224 & 270 \\
\hline $\mathrm{pH}$, standard units & 90 & 90 & 6.28 & 6.80 & 6.87 & 6.92 & 7.29 \\
\hline Specific conductance, $\mu \mathrm{S} / \mathrm{cm}$ at $25^{\circ} \mathrm{C}$ & 90 & 90 & 416 & 548 & 578 & 628 & 813 \\
\hline Water temperature, ${ }^{\circ} \mathrm{C}$ & 90 & 90 & 22.1 & 23.3 & 23.9 & 24.4 & 26.0 \\
\hline Alkalinity, $\mathrm{mg} / \mathrm{L}$ as $\mathrm{CaCO}_{3}$ & 85 & 85 & 134 & 250 & 268 & 293 & 338 \\
\hline $\begin{array}{l}\text { Dissolved solids (residue on evaporation, } \\
\left.\text { dried at } 180^{\circ} \mathrm{C}\right), \mathrm{mg} / \mathrm{L}\end{array}$ & 90 & 90 & 201 & 312 & 329 & 360 & 456 \\
\hline \multicolumn{8}{|c|}{ Major ions and selected saturation indexes and ion ratios } \\
\hline Calcium, mg/L & 90 & 90 & 74.0 & 95.2 & 101 & 111 & 144 \\
\hline Magnesium, mg/L & 90 & 90 & 1.47 & 5.06 & 8.11 & 9.64 & 18.3 \\
\hline Sulfate, $\mathrm{mg} / \mathrm{L}$ & 89 & 89 & 3.92 & 8.58 & 11.5 & 14.6 & 26.5 \\
\hline Silica, mg/L & 90 & 90 & 9.46 & 11.4 & 12.0 & 12.7 & 14.9 \\
\hline SI calcite & 90 & 90 & -.69 & -.18 & -.10 & -.04 & .26 \\
\hline SI dolomite & 90 & 90 & -2.42 & -1.17 & -.97 & -.83 & .005 \\
\hline SI gypsum & 90 & 90 & -2.82 & -2.53 & -2.39 & -2.27 & -1.60 \\
\hline $\mathrm{Mg} / \mathrm{Ca}$, molar ratio & 90 & 90 & .02 & .07 & .13 & .17 & .33 \\
\hline $\mathrm{Sr} / \mathrm{Ca}$, molar ratio $\left(\mathrm{x} 10^{3}\right)$ & 88 & 88 & .17 & .47 & .59 & .84 & 9.85 \\
\hline \multicolumn{8}{|c|}{ Nutrients } \\
\hline Nitrate plus nitrite, $\mathrm{mg} / \mathrm{L}$ as $\mathrm{N}$ & 90 & 89 & $<.05$ & 1.44 & 1.85 & 2.30 & 4.76 \\
\hline Nitrate, $\mathrm{mg} / \mathrm{L}$ as $\mathrm{N}$ & 90 & 89 & $<.05$ & 1.43 & 1.85 & 2.30 & 4.76 \\
\hline Ammonia, $\mathrm{mg} / \mathrm{L}$ as $\mathrm{N}$ & 90 & 42 & $<.010$ & $<.02$ & $<.04$ & .010 & .048 \\
\hline Nitrite, $\mathrm{mg} / \mathrm{L}$ as $\mathrm{N}$ & 90 & 6 & $<.002$ & $<.002$ & $<.008$ & $<.01$ & .011 \\
\hline Orthophosphate, $\mathrm{mg} / \mathrm{L}$ as $\mathrm{P}$ & 90 & 80 & $<.01$ & .010 & .014 & .018 & .030 \\
\hline Phosphorus, mg/L & 45 & 16 & $<.05$ & $<.05$ & $<.05$ & .007 & .208 \\
\hline Organic carbon, mg/L & 65 & 65 & .20 & .40 & .50 & .60 & 3.30 \\
\hline
\end{tabular}


Table 3. Summary statistics by group for field, physicochemical, inorganic, radiogenic, and stable isotope constituents analyzed in groundwater samples collected from the San Antonio segment of the Edwards aquifer, south-central Texas, 1996-2006-Continued.

\begin{tabular}{|c|c|c|c|c|c|c|c|}
\hline \multirow[b]{2}{*}{ Constituent } & \multicolumn{7}{|c|}{ Shallow/urban unconfined } \\
\hline & $\begin{array}{l}\text { Number of } \\
\text { samples }\end{array}$ & $\begin{array}{l}\text { Number of } \\
\text { detections }\end{array}$ & Minimum & $\begin{array}{c}\text { 25th } \\
\text { percentile }\end{array}$ & Median & $\begin{array}{c}\text { 75th } \\
\text { percentile }\end{array}$ & Maximum \\
\hline Aluminum, $\mu \mathrm{g} / \mathrm{L}$ & 87 & 10 & $<1$ & $<1$ & $<1.6$ & $<1.6$ & 46.2 \\
\hline Antimony, $\mu \mathrm{g} / \mathrm{L}$ & 87 & 3 & $<.05$ & $<.2$ & $<.30$ & $<1$ & .06 \\
\hline Barium, $\mu \mathrm{g} / \mathrm{L}$ & 87 & 87 & 22.9 & 32.1 & 36.9 & 42.3 & 69.9 \\
\hline Beryllium, $\mu \mathrm{g} / \mathrm{L}$ & 87 & 1 & $<.06$ & $<.06$ & $<.06$ & $<1$ & .04 \\
\hline Boron, $\mu \mathrm{g} / \mathrm{L}$ & 52 & 52 & 18.9 & 28.0 & 31.3 & 36.5 & 62.6 \\
\hline Cadmium, $\mu \mathrm{g} / \mathrm{L}$ & 87 & 0 & $<.04$ & $<.04$ & $<.04$ & $<1$ & $<1$ \\
\hline Chromium, $\mu \mathrm{g} / \mathrm{L}$ & 87 & 67 & $<.8$ & .20 & .44 & 2.09 & 5.57 \\
\hline Iron, $\mu \mathrm{g} / \mathrm{L}$ & 90 & 21 & $<6$ & $<6$ & $<10$ & $<10$ & 115 \\
\hline Lead, $\mu \mathrm{g} / \mathrm{L}$ & 83 & 24 & $<.08$ & $<.08$ & $<1$ & .05 & .15 \\
\hline Lithium, $\mu \mathrm{g} / \mathrm{L}$ & 52 & 52 & 1.07 & 1.43 & 1.83 & 2.33 & 3.82 \\
\hline Manganese, $\mu \mathrm{g} / \mathrm{L}$ & 89 & 36 & $<.2$ & $<1$ & $<1$ & .16 & 1.7 \\
\hline Molybdenum, $\mu \mathrm{g} / \mathrm{L}$ & 87 & 43 & $<.33$ & $<1$ & $<1$ & .36 & 1.38 \\
\hline Nickel, $\mu \mathrm{g} / \mathrm{L}$ & 87 & 75 & $<.06$ & .38 & 1.01 & 1.62 & 5.27 \\
\hline Selenium, $\mu \mathrm{g} / \mathrm{L}$ & 87 & 56 & $<.08$ & $<1$ & .26 & .35 & 1.4 \\
\hline Silver, $\mu \mathrm{g} / \mathrm{L}$ & 87 & 0 & $<.1$ & $<.20$ & $<.20$ & $<1$ & $<1$ \\
\hline Strontium, $\mu \mathrm{g} / \mathrm{L}$ & 88 & 88 & 39.7 & 104 & 137 & 188 & 1,907 \\
\hline$\delta \mathrm{D}$, per mil & 70 & 70 & -36.0 & -24.5 & -23.6 & -23.0 & -20.7 \\
\hline$\delta^{13} \mathrm{C}$, per mil & 30 & 30 & -15.70 & -11.68 & -10.65 & -10.23 & -8.50 \\
\hline${ }^{87} \mathrm{Sr} /{ }^{86} \mathrm{Sr}$, per mil & 35 & 35 & .70781 & .70830 & .70842 & .70853 & .70952 \\
\hline Radon-222, pCi/L & 0 & -- & -- & -- & -- & -- & -- \\
\hline Radium-226, pCi/L & 0 & -- & -- & -- & -- & -- & -- \\
\hline Radium-228, pCi/L & 0 & -- & -- & -- & -- & -- & -- \\
\hline Tritium, pCi/L & 56 & 56 & 3.70 & 6.10 & 7.40 & 9.30 & 14.70 \\
\hline Tritium, TU & 56 & 56 & 1.2 & 1.9 & 2.3 & 2.9 & 4.6 \\
\hline
\end{tabular}


Table 3. Summary statistics by group for field, physicochemical, inorganic, radiogenic, and stable isotope constituents analyzed in groundwater samples collected from the San Antonio segment of the Edwards aquifer, south-central Texas, 1996-2006 —Continued.

\begin{tabular}{|c|c|c|c|c|c|c|c|}
\hline Constituent & \multicolumn{7}{|c|}{ Unconfined } \\
\hline $\begin{array}{l}\text { Land-surface altitude, } \mathrm{ft} \text { above NAVD } \\
\quad 1988\end{array}$ & 38 & 38 & 610 & 905 & 1,042 & 1,112 & 1,242 \\
\hline $\begin{array}{l}\text { Depth to top of open or screened interval, } \\
\mathrm{ft} \text { from land surface }\end{array}$ & 38 & 22 & 6.00 & 102 & 180 & 239 & 900 \\
\hline $\begin{array}{l}\text { Depth to bottom of open or screened } \\
\text { interval, ft from land surface }\end{array}$ & 38 & 22 & 80.0 & 251 & 367 & 450 & 1,400 \\
\hline Depth to water, ft below land surface & 17 & 17 & 36.4 & 119 & 182 & 220 & 353 \\
\hline $\mathrm{pH}$, standard units & 81 & 81 & 6.53 & 6.87 & 7.00 & 7.11 & 7.43 \\
\hline Specific conductance, $\mu \mathrm{S} / \mathrm{cm}$ at $25^{\circ} \mathrm{C}$ & 81 & 81 & 377 & 455 & 506 & 581 & 1,003 \\
\hline Water temperature, ${ }^{\circ} \mathrm{C}$ & 80 & 80 & 21.1 & 22.5 & 22.8 & 23.3 & 28.2 \\
\hline Alkalinity, $\mathrm{mg} / \mathrm{L}$ as $\mathrm{CaCO}_{3}$ & 82 & 82 & 121 & 203 & 231 & 273 & 377 \\
\hline $\begin{array}{l}\text { Dissolved solids (residue on evaporation, } \\
\left.\text { dried at } 180^{\circ} \mathrm{C}\right), \mathrm{mg} / \mathrm{L}\end{array}$ & 79 & 79 & 214 & 259 & 294 & 328 & 3,852 \\
\hline \multicolumn{8}{|c|}{ Major ions and selected saturation indexes and ion ratios } \\
\hline Calcium, mg/L & 82 & 82 & 51.8 & 66.1 & 78.5 & 94.1 & 153 \\
\hline Magnesium, mg/L & 82 & 82 & 3.56 & 9.11 & 12.7 & 16.1 & 31.1 \\
\hline Sulfate, $\mathrm{mg} / \mathrm{L}$ & 82 & 82 & 4.80 & 10.0 & 13.1 & 20.0 & 81.8 \\
\hline Silica, mg/L & 82 & 82 & 9.44 & 11.4 & 12.0 & 13.0 & 14.7 \\
\hline SI calcite & 80 & 80 & -.62 & -.23 & -.18 & -.06 & .43 \\
\hline SI dolomite & 80 & 80 & -1.80 & -1.03 & -.78 & -.54 & .23 \\
\hline SI gypsum & 80 & 80 & -2.96 & -2.52 & -2.45 & -2.19 & -1.49 \\
\hline $\mathrm{Mg} / \mathrm{Ca}$, molar ratio & 80 & 80 & .06 & .18 & .27 & .37 & .76 \\
\hline $\mathrm{Sr} / \mathrm{Ca}$, molar ratio $\left(\mathrm{x} 10^{3}\right)$ & 74 & 74 & .19 & .94 & 1.67 & 2.04 & 5.40 \\
\hline \multicolumn{8}{|c|}{ Nutrients } \\
\hline Nitrate plus nitrite, $\mathrm{mg} / \mathrm{L}$ as $\mathrm{N}$ & 82 & 81 & $<.06$ & .79 & 1.05 & 1.58 & 7.94 \\
\hline Nitrate, $\mathrm{mg} / \mathrm{L}$ as $\mathrm{N}$ & 80 & 79 & $<.06$ & .78 & 1.09 & 1.60 & 7.94 \\
\hline Ammonia, mg/L as $\mathrm{N}$ & 82 & 29 & $<.010$ & $<.015$ & $<.04$ & .021 & .102 \\
\hline Nitrite, $\mathrm{mg} / \mathrm{L}$ as $\mathrm{N}$ & 82 & 13 & $<.002$ & $<.006$ & $<.008$ & $<.01$ & .018 \\
\hline Orthophosphate, $\mathrm{mg} / \mathrm{L}$ as $\mathrm{P}$ & 82 & 54 & $<.006$ & $<.018$ & .008 & .012 & .020 \\
\hline Phosphorus, mg/L & 37 & 10 & $<.004$ & $<.01$ & $<.01$ & .003 & .028 \\
\hline Organic carbon, mg/L & 61 & 61 & .20 & .30 & .40 & .43 & 2.43 \\
\hline
\end{tabular}


Table 3. Summary statistics by group for field, physicochemical, inorganic, radiogenic, and stable isotope constituents analyzed in groundwater samples collected from the San Antonio segment of the Edwards aquifer, south-central Texas, 1996-2006-Continued.

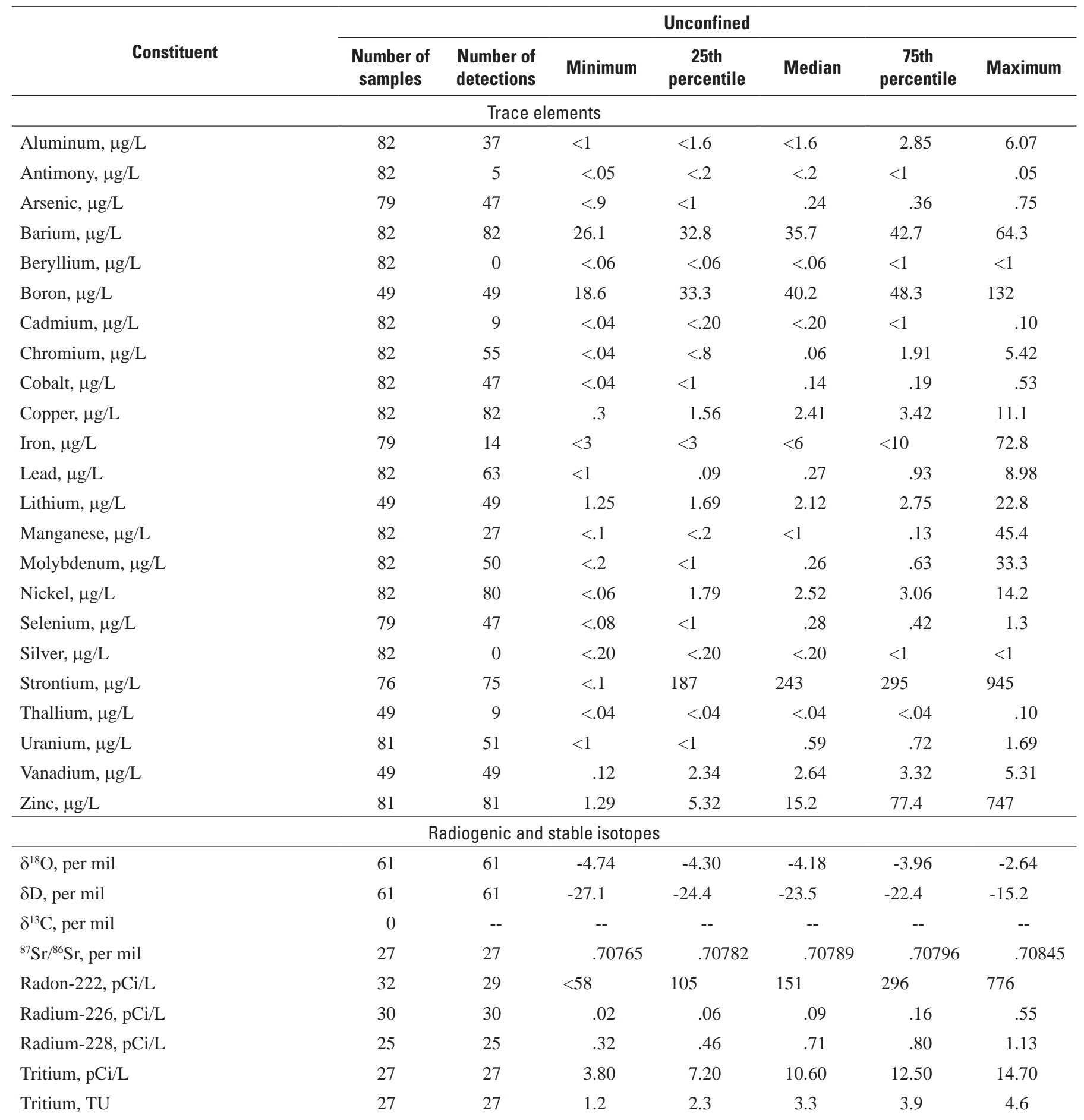


Table 3. Summary statistics by group for field, physicochemical, inorganic, radiogenic, and stable isotope constituents analyzed in groundwater samples collected from the San Antonio segment of the Edwards aquifer, south-central Texas, 1996-2006 —Continued.

\begin{tabular}{|c|c|c|c|c|c|c|c|}
\hline \multirow[b]{2}{*}{ Constituent } & \multicolumn{7}{|c|}{ Confined } \\
\hline & $\begin{array}{l}\text { Number of } \\
\text { samples }\end{array}$ & $\begin{array}{l}\text { Number of } \\
\text { detections }\end{array}$ & Minimum & $\begin{array}{c}\text { 25th } \\
\text { percentile }\end{array}$ & Median & $\begin{array}{c}\text { 75th } \\
\text { percentile }\end{array}$ & Maximum \\
\hline $\begin{array}{l}\text { Land-surface altitude, } \mathrm{ft} \text { above NAVD } \\
1988\end{array}$ & 68 & 68 & 600 & 201 & 834 & 911 & 1,125 \\
\hline $\begin{array}{l}\text { Depth to bottom of open or screened } \\
\text { interval, ft from land surface }\end{array}$ & 68 & 61 & 215 & 99.5 & 848 & 1,462 & 2,700 \\
\hline Depth to water, ft below land surface & 1 & 1 & 22.5 & 22.5 & 22.5 & 22.5 & 22.5 \\
\hline $\mathrm{pH}$, standard units & 79 & 79 & 6.61 & 6.94 & 7.08 & 7.17 & 7.42 \\
\hline Specific conductance, $\mu \mathrm{S} / \mathrm{cm}$ at $25^{\circ} \mathrm{C}$ & 79 & 79 & 384 & 494 & 525 & 589 & 1,199 \\
\hline Water temperature, ${ }^{\circ} \mathrm{C}$ & 79 & 79 & 21.5 & 23.0 & 23.7 & 24.7 & 32.5 \\
\hline Alkalinity, $\mathrm{mg} / \mathrm{L}$ as $\mathrm{CaCO}_{3}$ & 79 & 79 & 155 & 203 & 211 & 250 & 304 \\
\hline $\begin{array}{l}\text { Dissolved solids (residue on evaporation, } \\
\left.\text { dried at } 180^{\circ} \mathrm{C}\right), \mathrm{mg} / \mathrm{L}\end{array}$ & 70 & 70 & 259 & 284 & 297 & 330 & 891 \\
\hline \multicolumn{8}{|c|}{ Major ions and selected saturation indexes and ion ratios } \\
\hline Calcium, mg/L & 71 & 71 & 50.3 & 68.9 & 73.4 & 87.5 & 153 \\
\hline Magnesium, mg/L & 71 & 71 & 5.49 & 13.7 & 15.5 & 16.6 & 24.15 \\
\hline Sulfate, $\mathrm{mg} / \mathrm{L}$ & 71 & 71 & 6.66 & 16.2 & 18.7 & 24.8 & 87.6 \\
\hline Silica, mg/L & 71 & 71 & 10.2 & 11.9 & 12.6 & 13.4 & 16.4 \\
\hline SI calcite & 70 & 70 & -.42 & -.18 & -.08 & 0 & .15 \\
\hline SI dolomite & 70 & 70 & -1.52 & -.78 & -.47 & -.36 & -.05 \\
\hline SI gypsum & 70 & 70 & -2.71 & -2.36 & -2.30 & -2.16 & -1.50 \\
\hline $\mathrm{Mg} / \mathrm{Ca}$, molar ratio & 70 & 70 & .09 & .24 & .35 & .38 & .79 \\
\hline $\mathrm{Sr} / \mathrm{Ca}$, molar ratio $\left(\mathrm{x} 10^{3}\right)$ & 68 & 68 & .84 & 2.14 & 3.08 & 5.53 & 60.0 \\
\hline \multicolumn{8}{|c|}{ Nutrients } \\
\hline Nitrate plus nitrite, $\mathrm{mg} / \mathrm{L}$ as $\mathrm{N}$ & 71 & 71 & .25 & 1.54 & 1.82 & 2.16 & 8.23 \\
\hline Nitrate, $\mathrm{mg} / \mathrm{L}$ as $\mathrm{N}$ & 70 & 70 & .19 & 1.53 & 1.84 & 2.16 & 8.23 \\
\hline Ammonia, mg/L as $\mathrm{N}$ & 71 & 9 & $<.010$ & $<.04$ & $<.04$ & $<.04$ & .060 \\
\hline Nitrite, $\mathrm{mg} / \mathrm{L}$ as $\mathrm{N}$ & 71 & 2 & $<.008$ & $<.008$ & $<.01$ & $<.01$ & .060 \\
\hline Orthophosphate, $\mathrm{mg} / \mathrm{L}$ as $\mathrm{P}$ & 71 & 33 & $<.006$ & $<.01$ & $<.01$ & .006 & .016 \\
\hline Phosphorus, mg/L & 37 & 1 & $<.01$ & $<.01$ & $<.01$ & $<.01$ & .012 \\
\hline Organic carbon, mg/L & 65 & 65 & .20 & .30 & .40 & .50 & 15.6 \\
\hline
\end{tabular}


Table 3. Summary statistics by group for field, physicochemical, inorganic, radiogenic, and stable isotope constituents analyzed in groundwater samples collected from the San Antonio segment of the Edwards aquifer, south-central Texas, 1996-2006-Continued.

\begin{tabular}{|c|c|c|c|c|c|c|c|}
\hline \multirow[b]{2}{*}{ Constituent } & \multicolumn{7}{|c|}{ Confined } \\
\hline & $\begin{array}{l}\text { Number of } \\
\text { samples }\end{array}$ & $\begin{array}{l}\text { Number of } \\
\text { detections }\end{array}$ & Minimum & $\begin{array}{c}\text { 25th } \\
\text { percentile }\end{array}$ & Median & $\begin{array}{c}\text { 75th } \\
\text { percentile }\end{array}$ & Maximum \\
\hline \multicolumn{8}{|c|}{ Trace elements } \\
\hline Aluminum, $\mu \mathrm{g} / \mathrm{L}$ & 69 & 48 & $<1.6$ & $<1.6$ & 2.04 & 3.78 & 4.81 \\
\hline Antimony, $\mu \mathrm{g} / \mathrm{L}$ & 69 & 0 & $<.2$ & $<.2$ & $<.30$ & $<1$ & $<1$ \\
\hline Barium, $\mu \mathrm{g} / \mathrm{L}$ & 69 & 69 & 27.4 & 37.1 & 47.0 & 57.4 & 223 \\
\hline Beryllium, $\mu \mathrm{g} / \mathrm{L}$ & 69 & 2 & $<.06$ & $<.06$ & $<1$ & $<1$ & .04 \\
\hline Boron, $\mu \mathrm{g} / \mathrm{L}$ & 34 & 34 & 41.6 & 51.1 & 57.7 & 65.0 & 89.5 \\
\hline Cadmium, $\mu \mathrm{g} / \mathrm{L}$ & 69 & 1 & $<.04$ & $<.04$ & $<1$ & $<1$ & .02 \\
\hline Chromium, $\mu \mathrm{g} / \mathrm{L}$ & 69 & 36 & $<.8$ & $<.8$ & .65 & 3.25 & 6.39 \\
\hline Iron, $\mu \mathrm{g} / \mathrm{L}$ & 70 & 9 & $<3$ & $<3$ & $<6$ & $<6$ & 24.0 \\
\hline Lead, $\mu \mathrm{g} / \mathrm{L}$ & 69 & 45 & $<1$ & $<1$ & .30 & 1.28 & 5.24 \\
\hline Lithium, $\mu \mathrm{g} / \mathrm{L}$ & 34 & 34 & 2.14 & 3.14 & 3.88 & 4.90 & 12.5 \\
\hline Manganese, $\mu \mathrm{g} / \mathrm{L}$ & 71 & 8 & $<.18$ & $<.2$ & $<1$ & $<1$ & 67.0 \\
\hline Molybdenum, $\mu \mathrm{g} / \mathrm{L}$ & 69 & 42 & $<1$ & $<1$ & .62 & .77 & 26.2 \\
\hline Nickel, $\mu \mathrm{g} / \mathrm{L}$ & 69 & 46 & $<1$ & $<1$ & 1.08 & 3.01 & 10.5 \\
\hline Selenium, $\mu \mathrm{g} / \mathrm{L}$ & 68 & 37 & $<1$ & $<1$ & .51 & .74 & 1.56 \\
\hline Silver, $\mu \mathrm{g} / \mathrm{L}$ & 69 & 0 & $<.20$ & $<.20$ & $<.20$ & $<1$ & $<1$ \\
\hline Strontium, $\mu \mathrm{g} / \mathrm{L}$ & 68 & 68 & 140 & 352 & 540 & 886 & 44,000 \\
\hline$\delta \mathrm{D}$, per mil & 37 & 37 & -26.7 & -23.1 & -24.0 & -23.1 & -17.3 \\
\hline$\delta^{13} \mathrm{C}$, per mil & 0 & -- & -- & -- & -- & -- & -- \\
\hline${ }^{87} \mathrm{Sr} /{ }^{86} \mathrm{Sr}$, per mil & 3 & 3 & .70768 & .70788 & .70784 & .70788 & .70791 \\
\hline Radon-222, pCi/L & 30 & 16 & $<80$ & 187 & 89 & 187 & 535 \\
\hline Radium-226, pCi/L & 0 & -- & -- & -- & -- & -- & -- \\
\hline Radium-228, pCi/L & 0 & -- & -- & -- & -- & -- & -- \\
\hline Tritium, pCi/L & 35 & 35 & 1.00 & 10.40 & 8.60 & 10.40 & 12.80 \\
\hline Tritium, TU & 35 & 35 & .3 & 3.3 & 2.7 & 3.3 & 4.0 \\
\hline
\end{tabular}




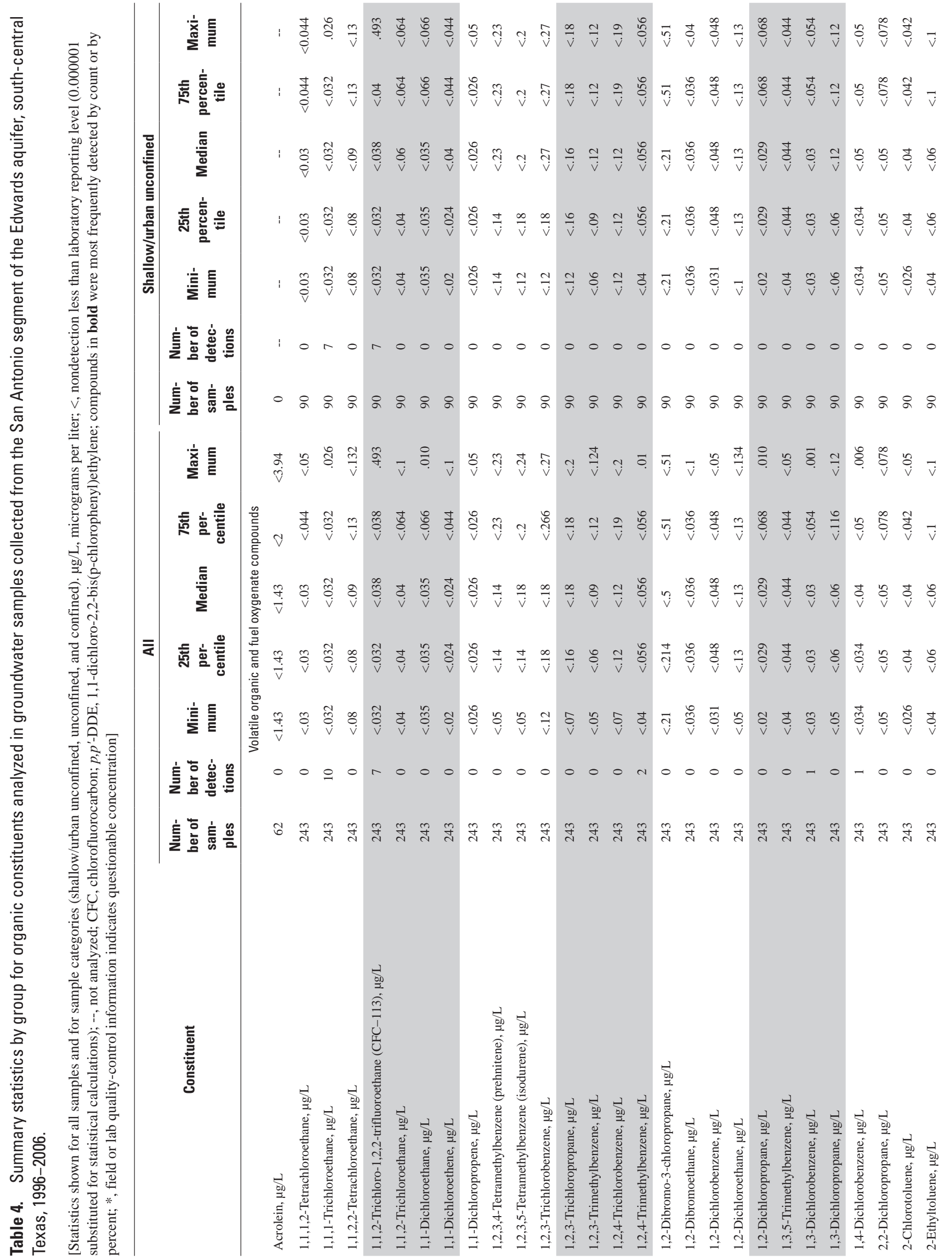




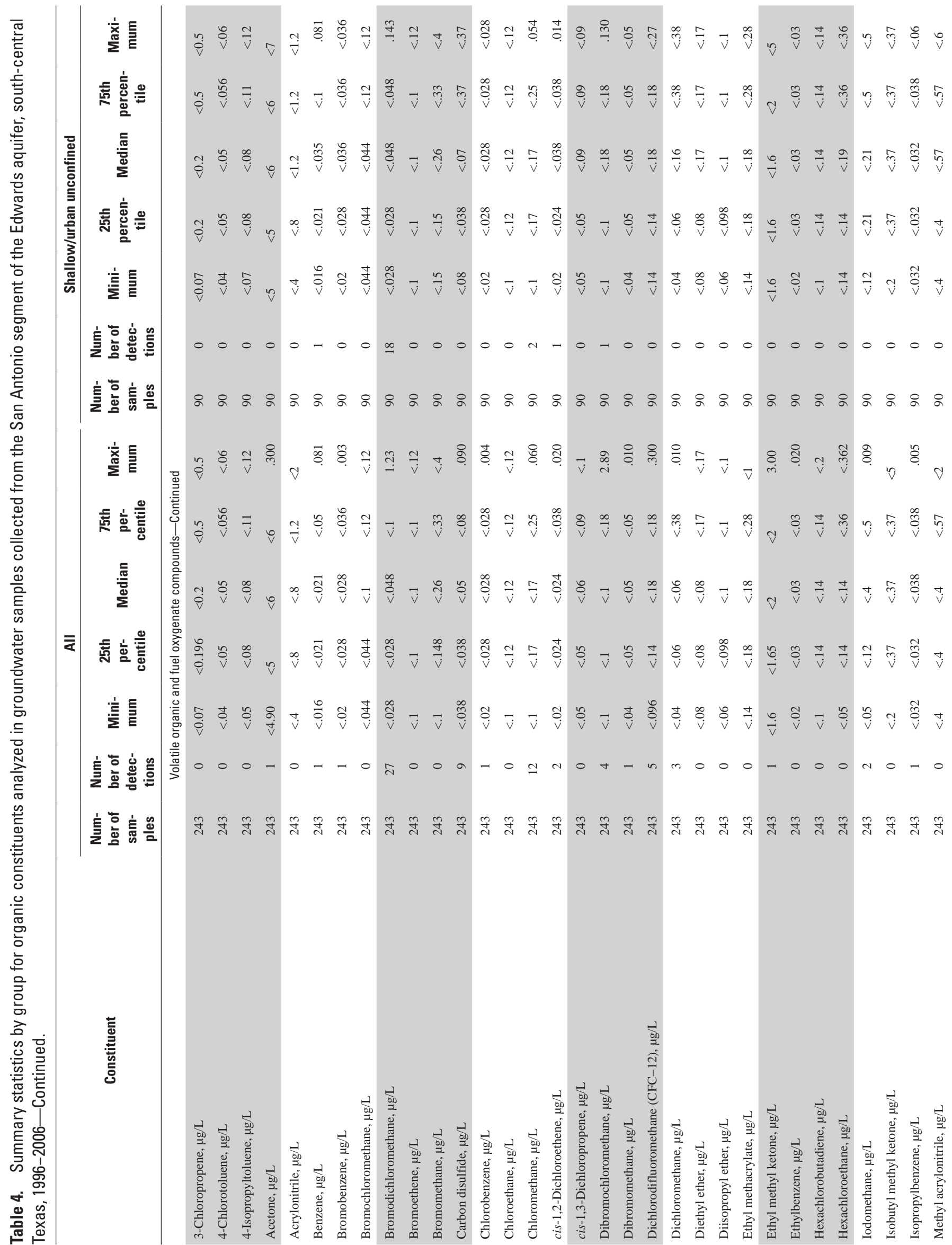




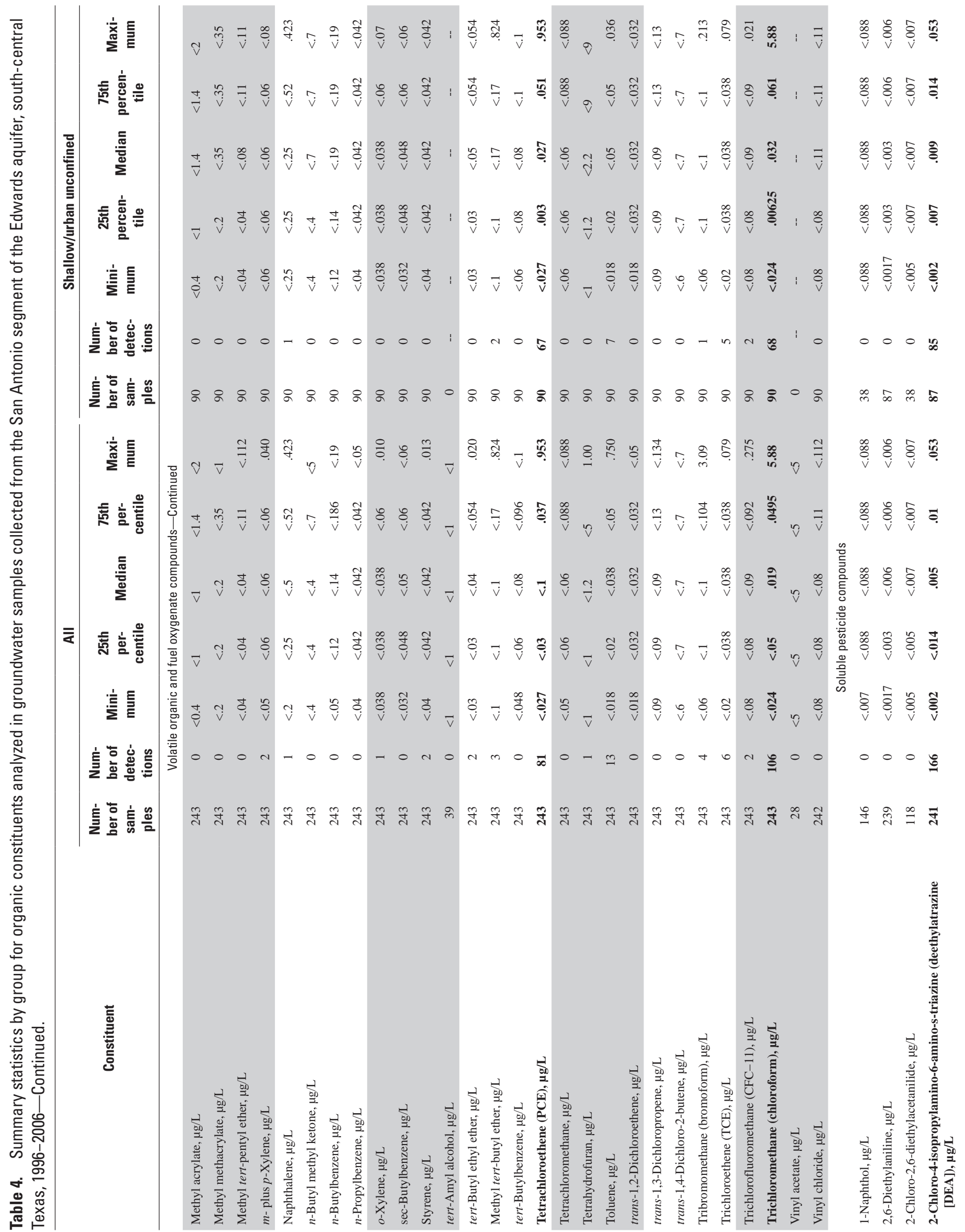




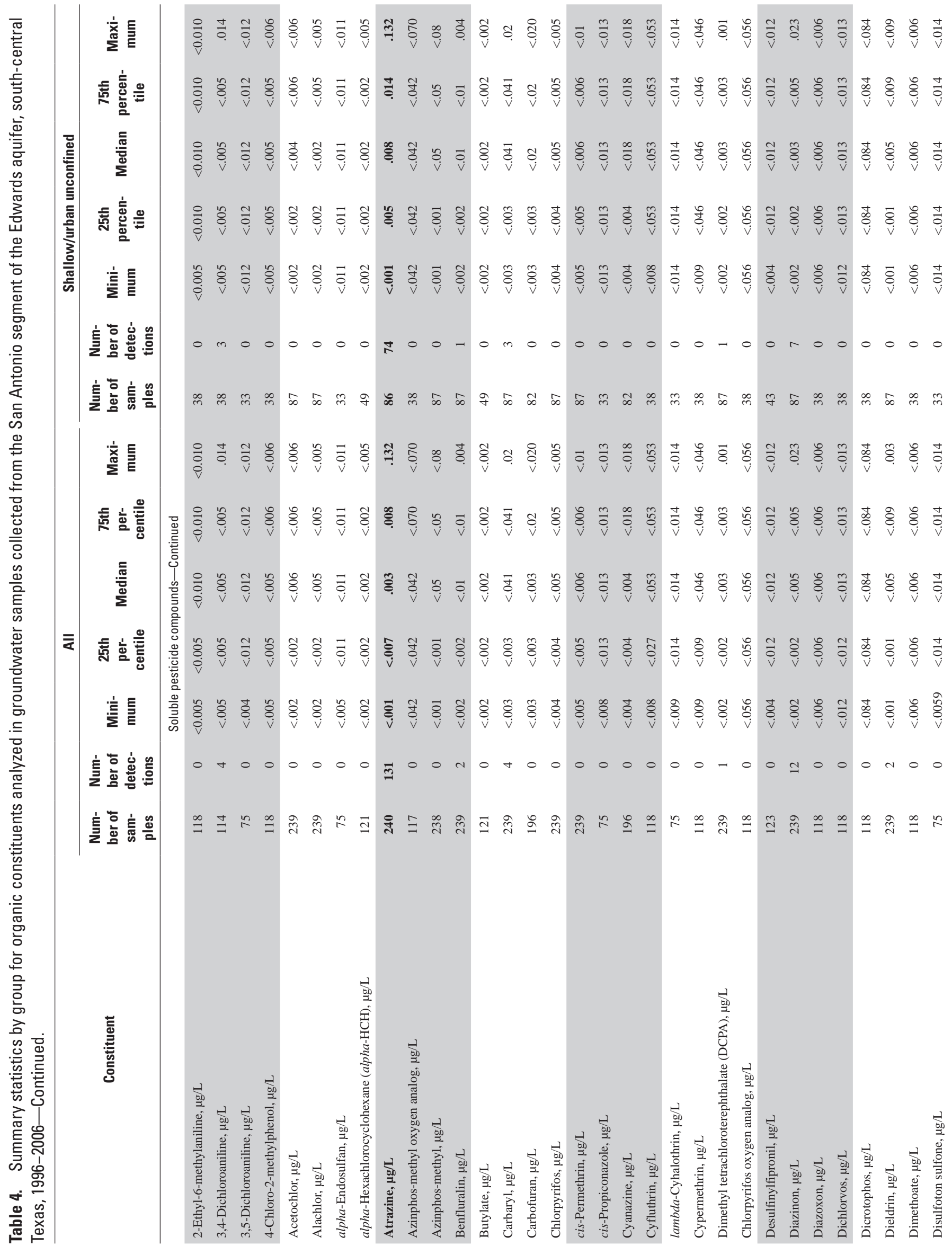




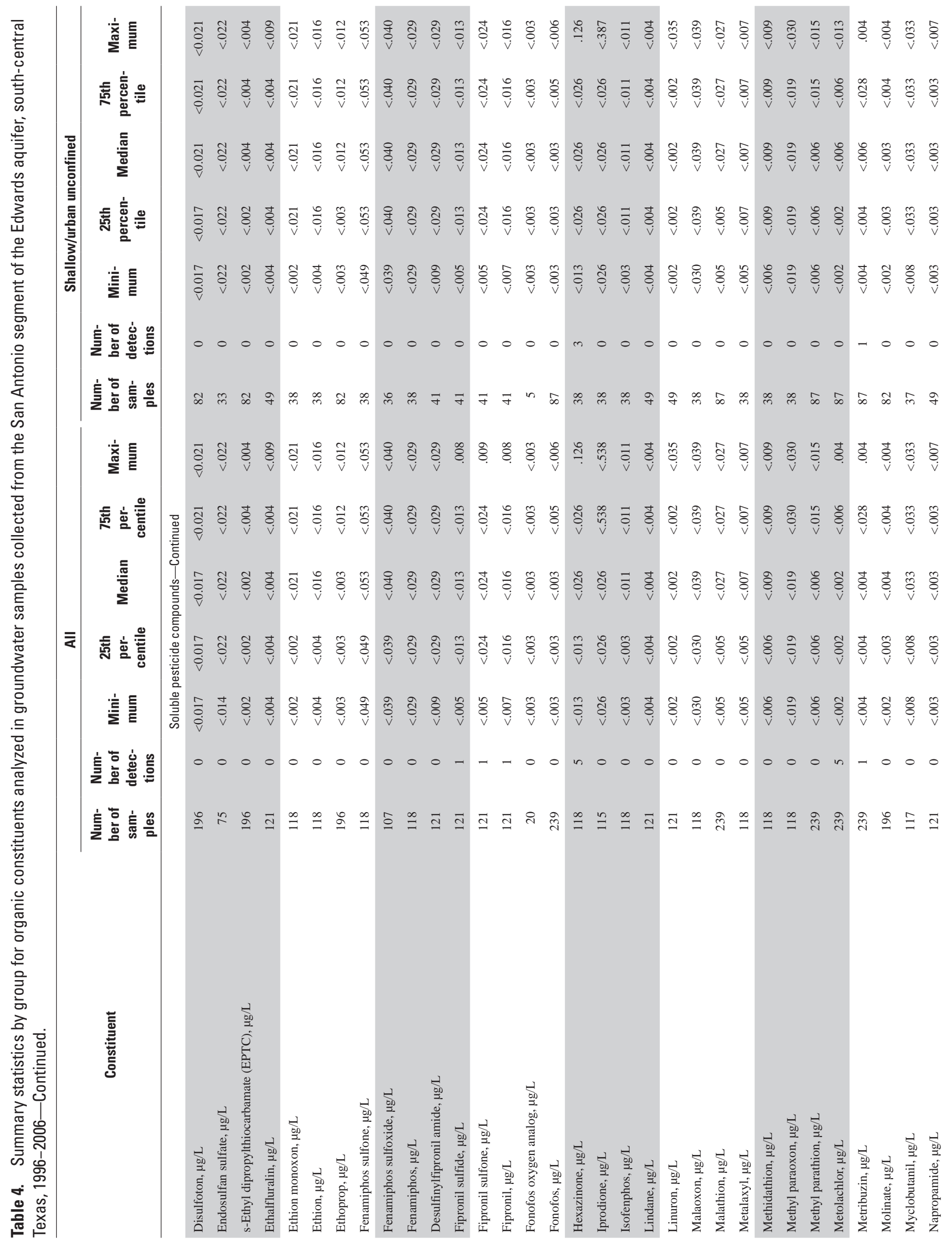




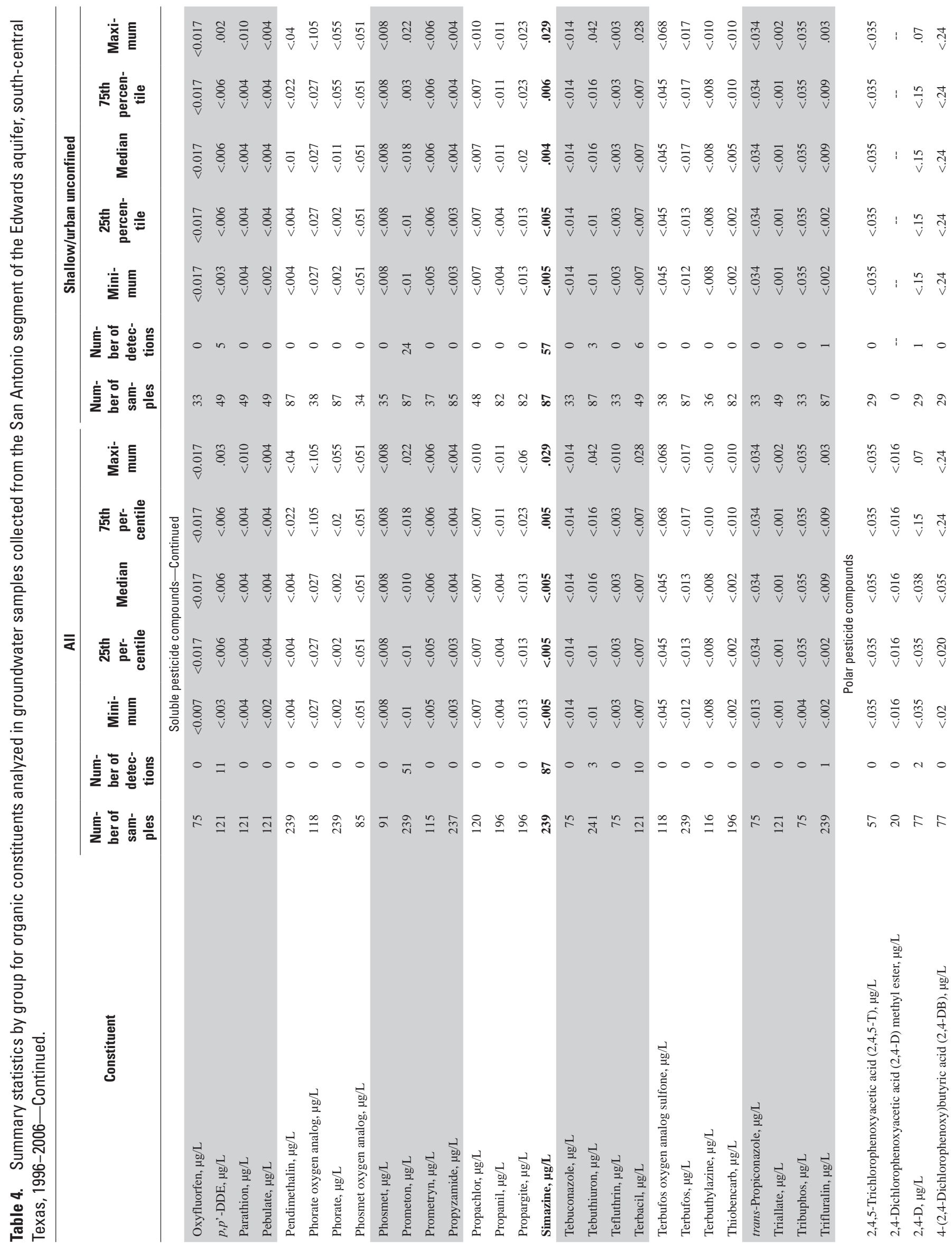




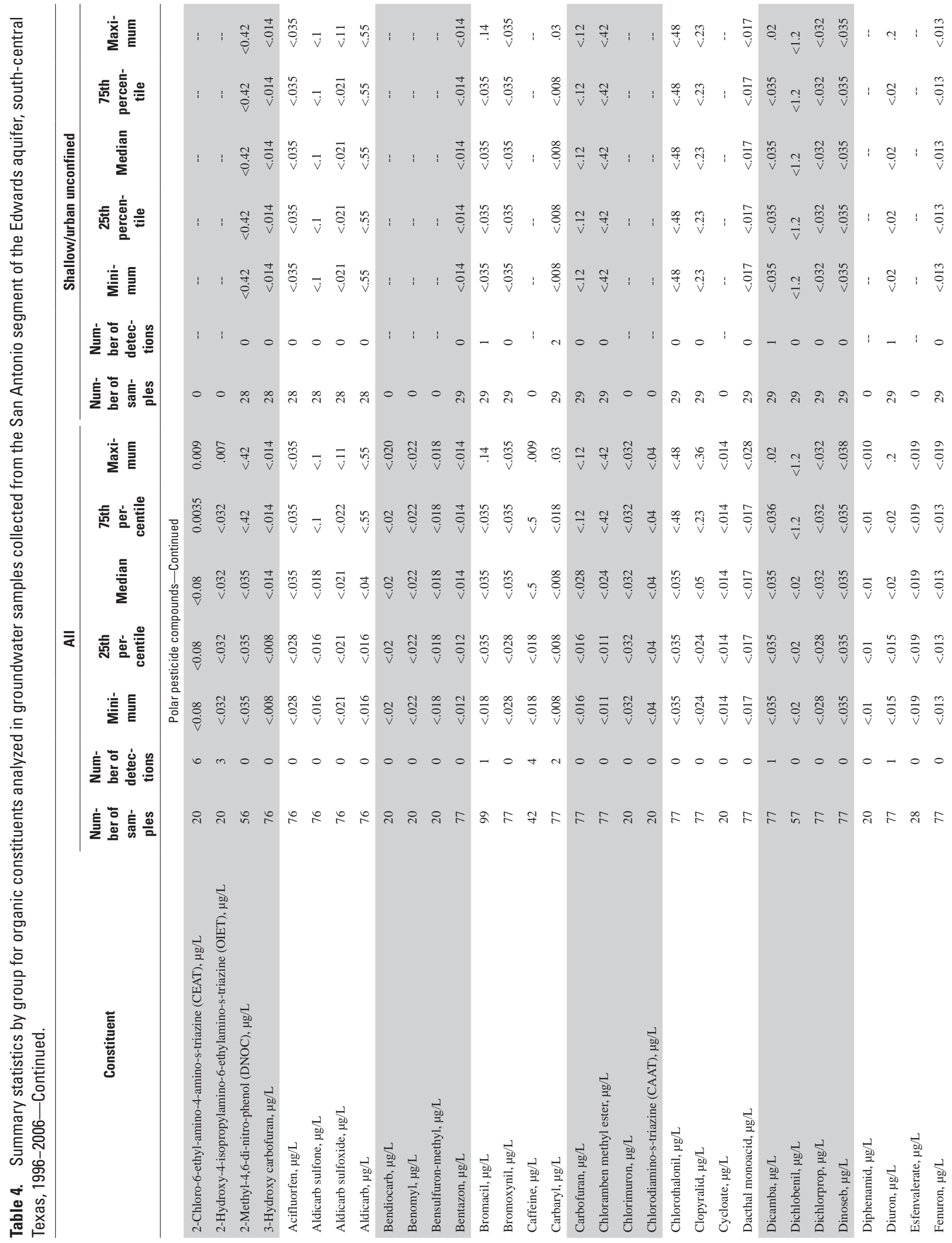




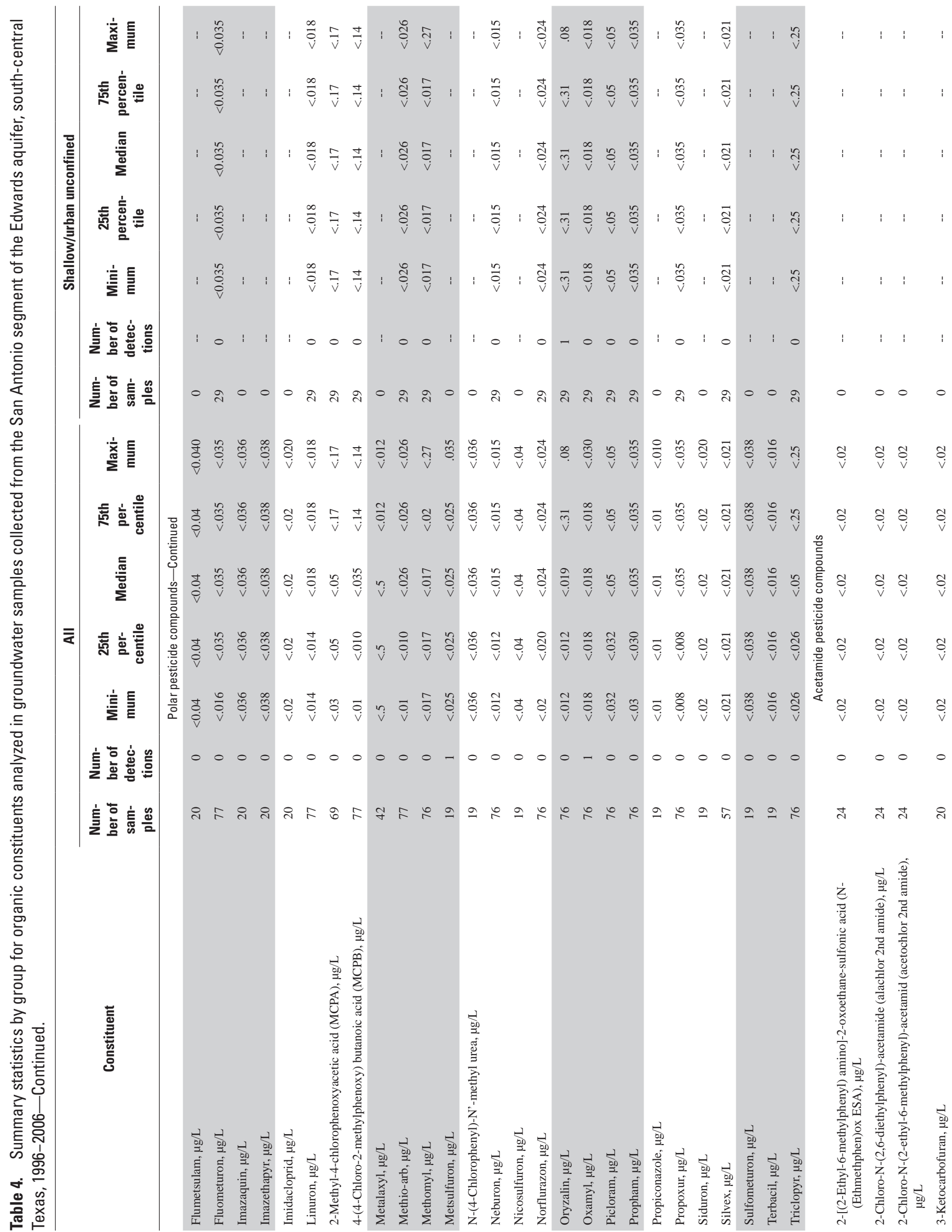




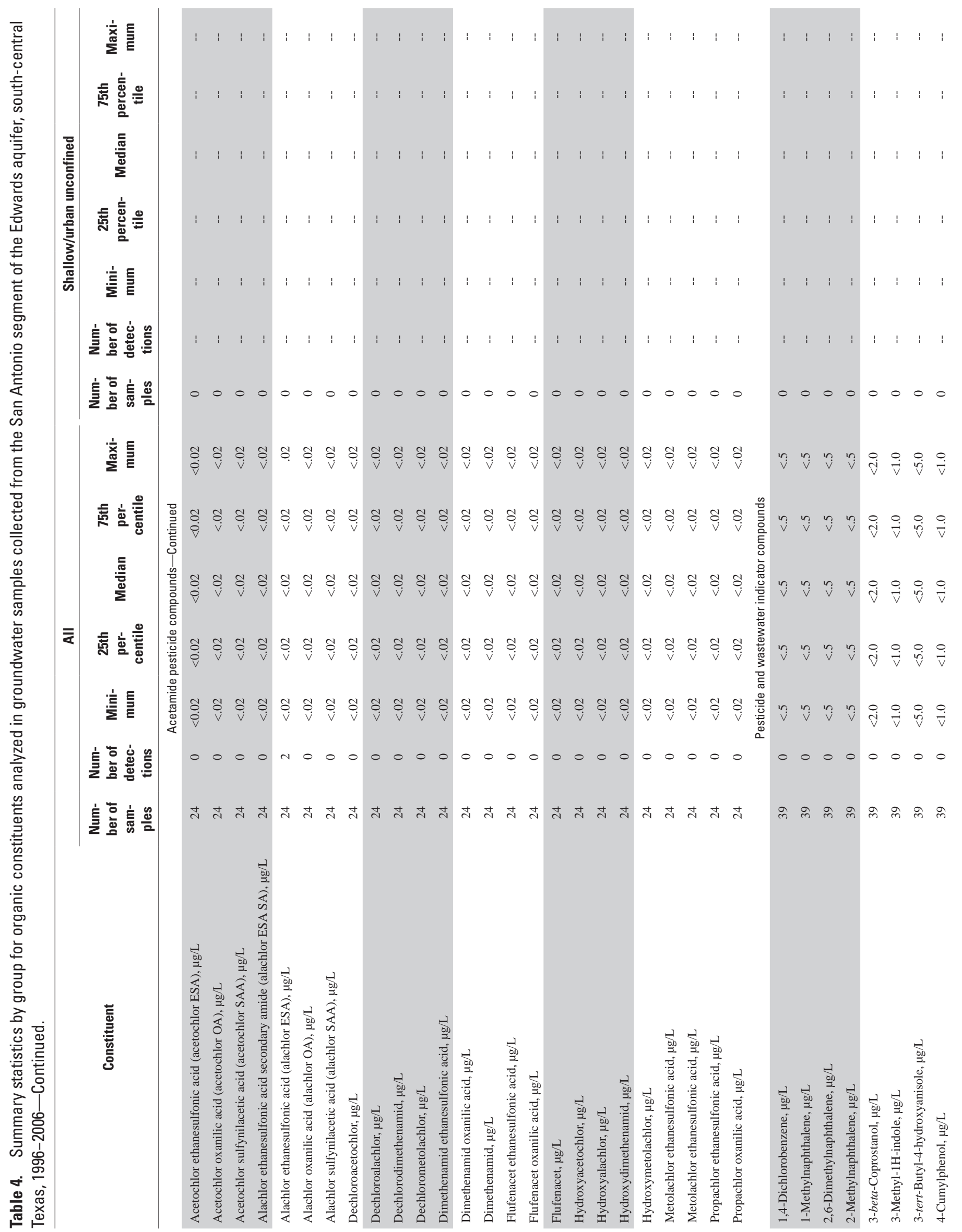




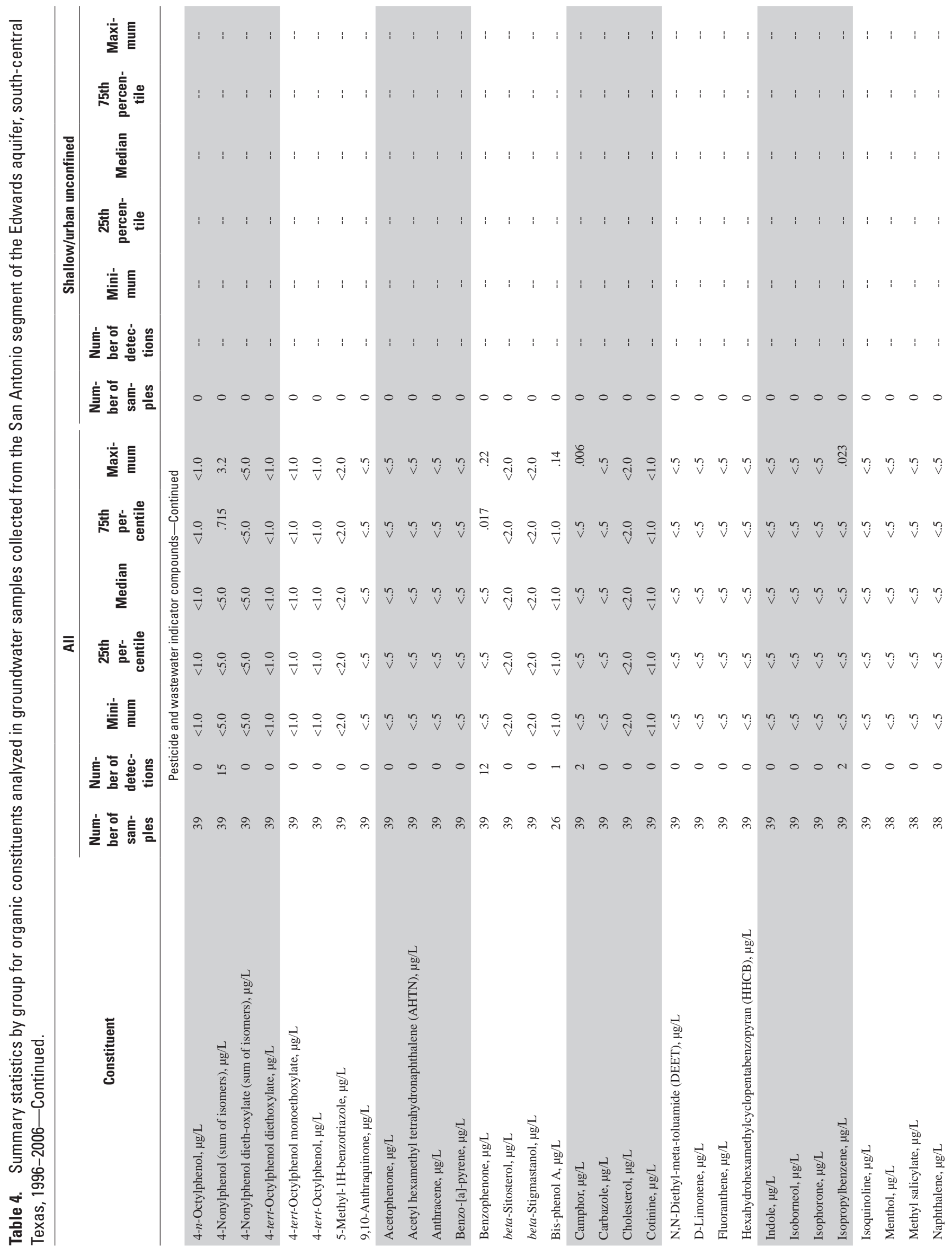




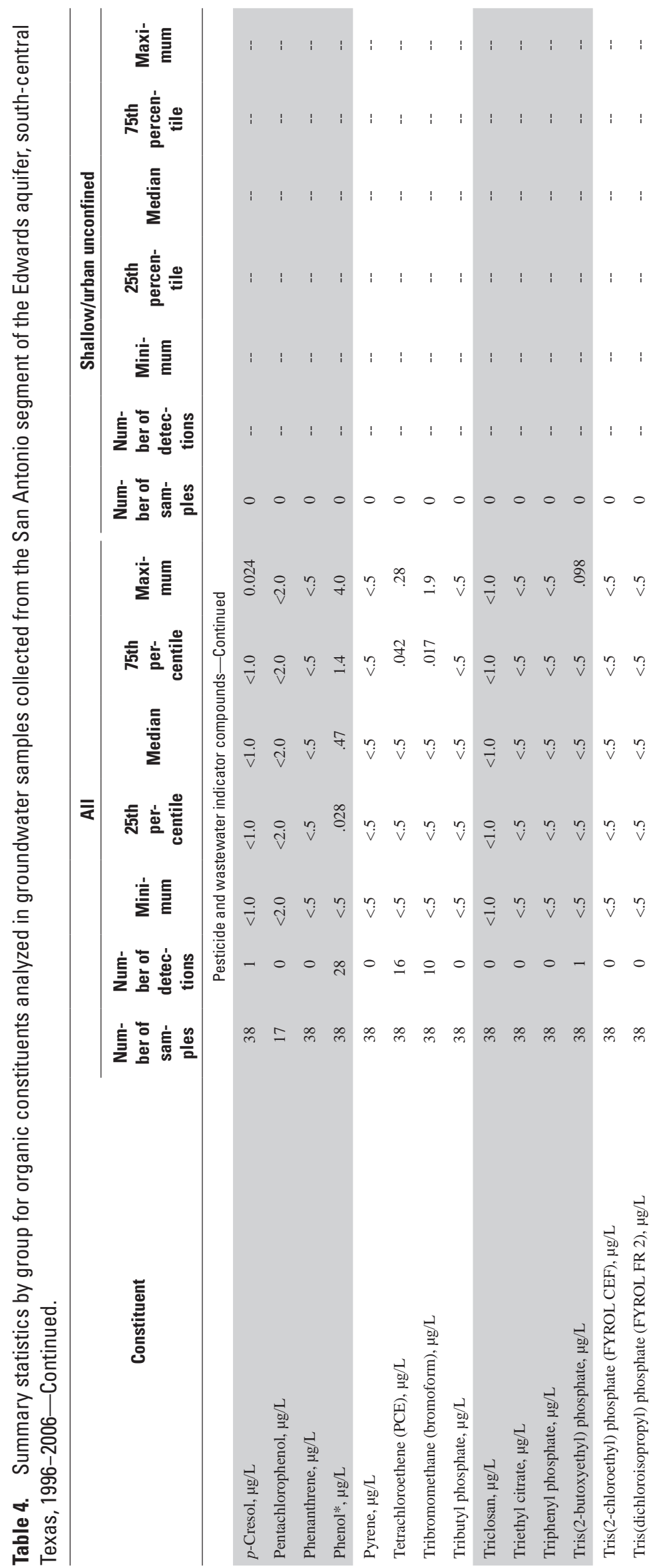




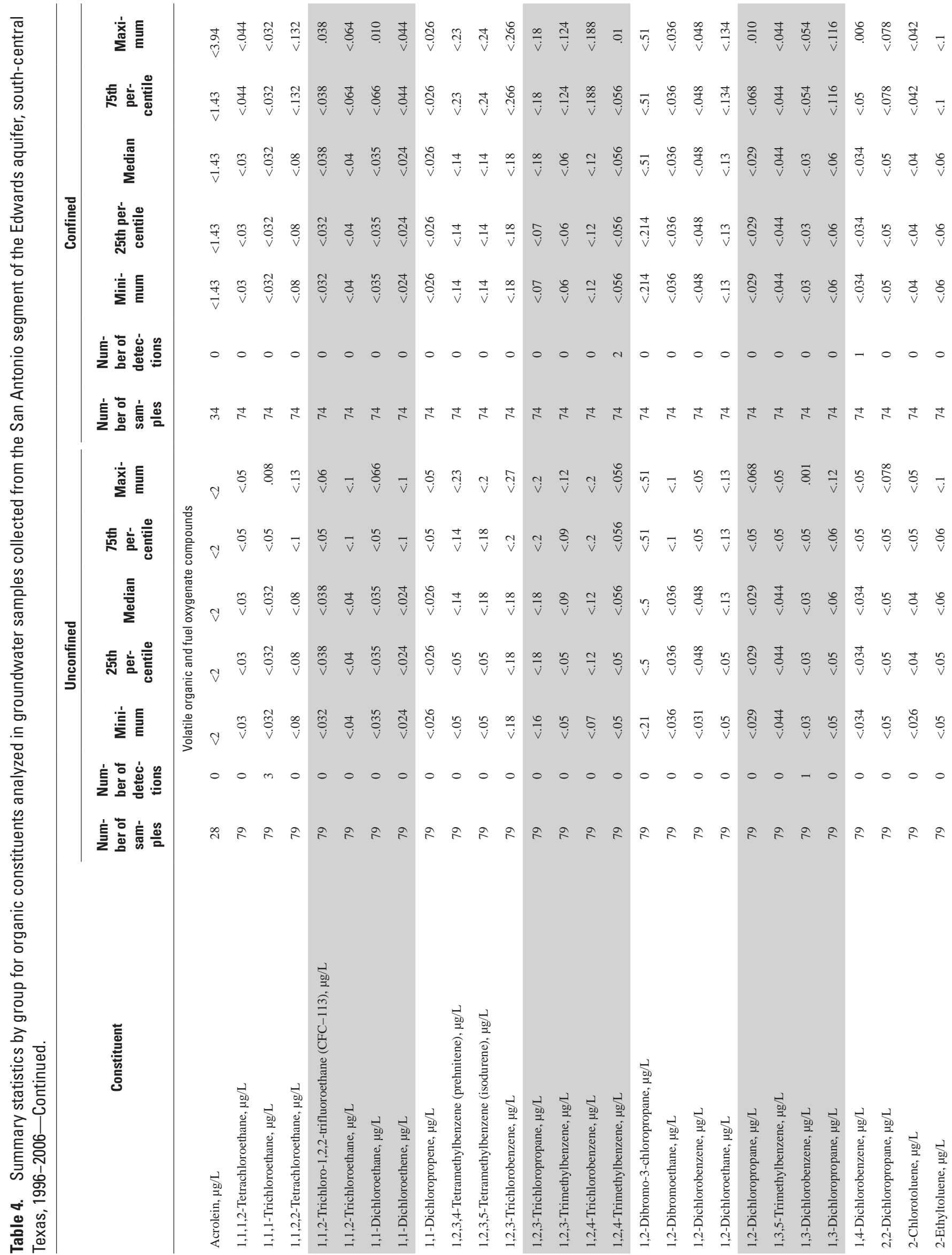




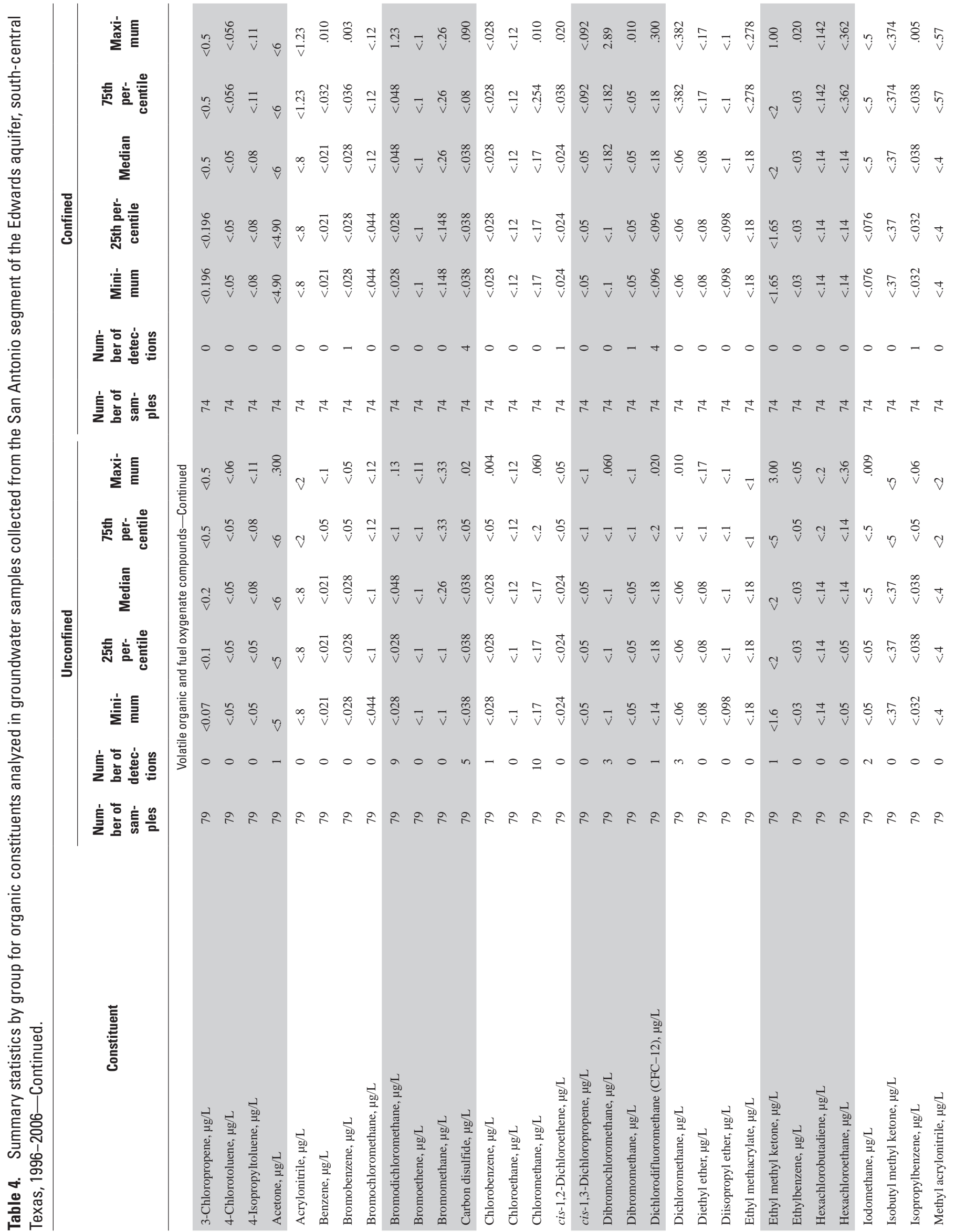




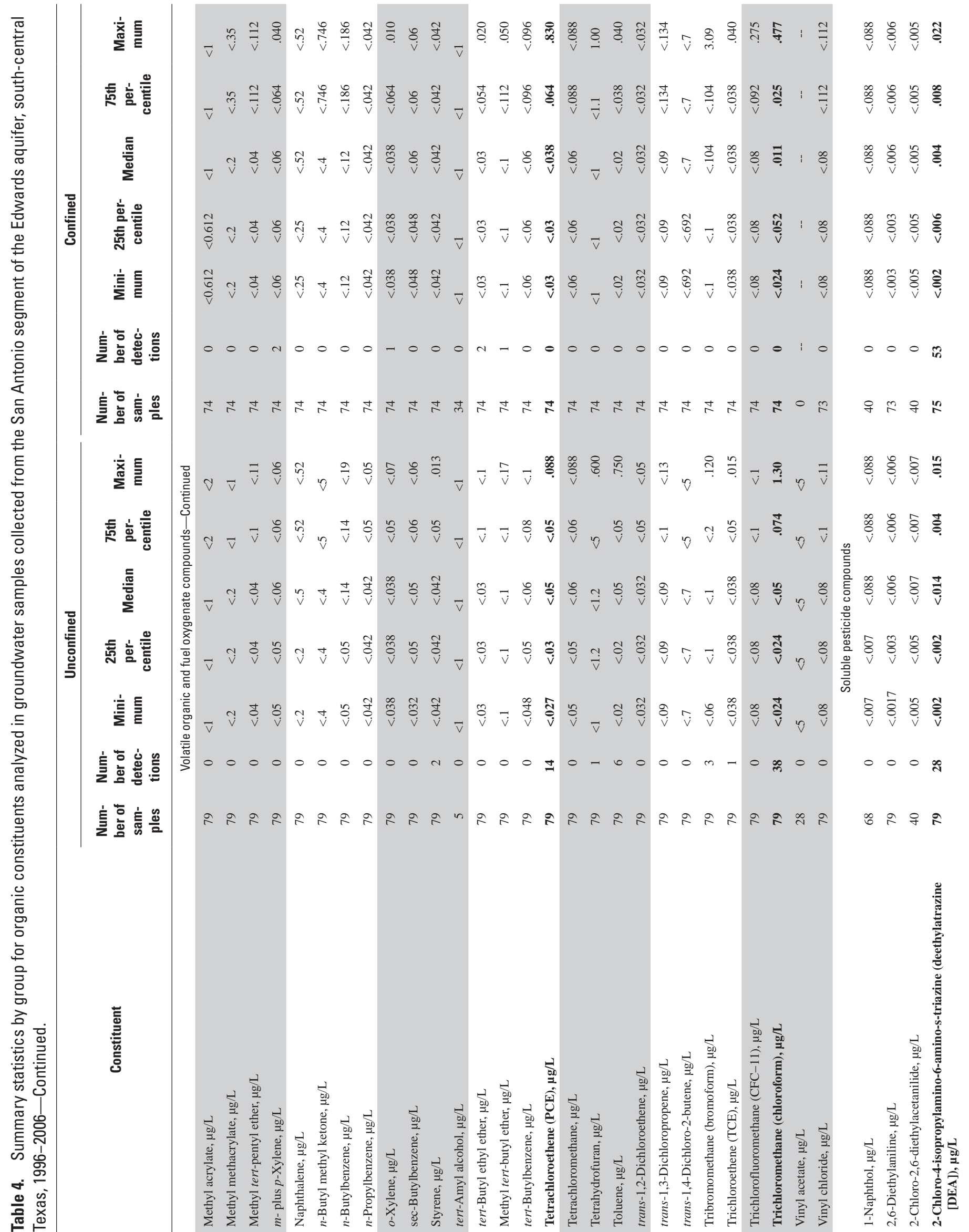




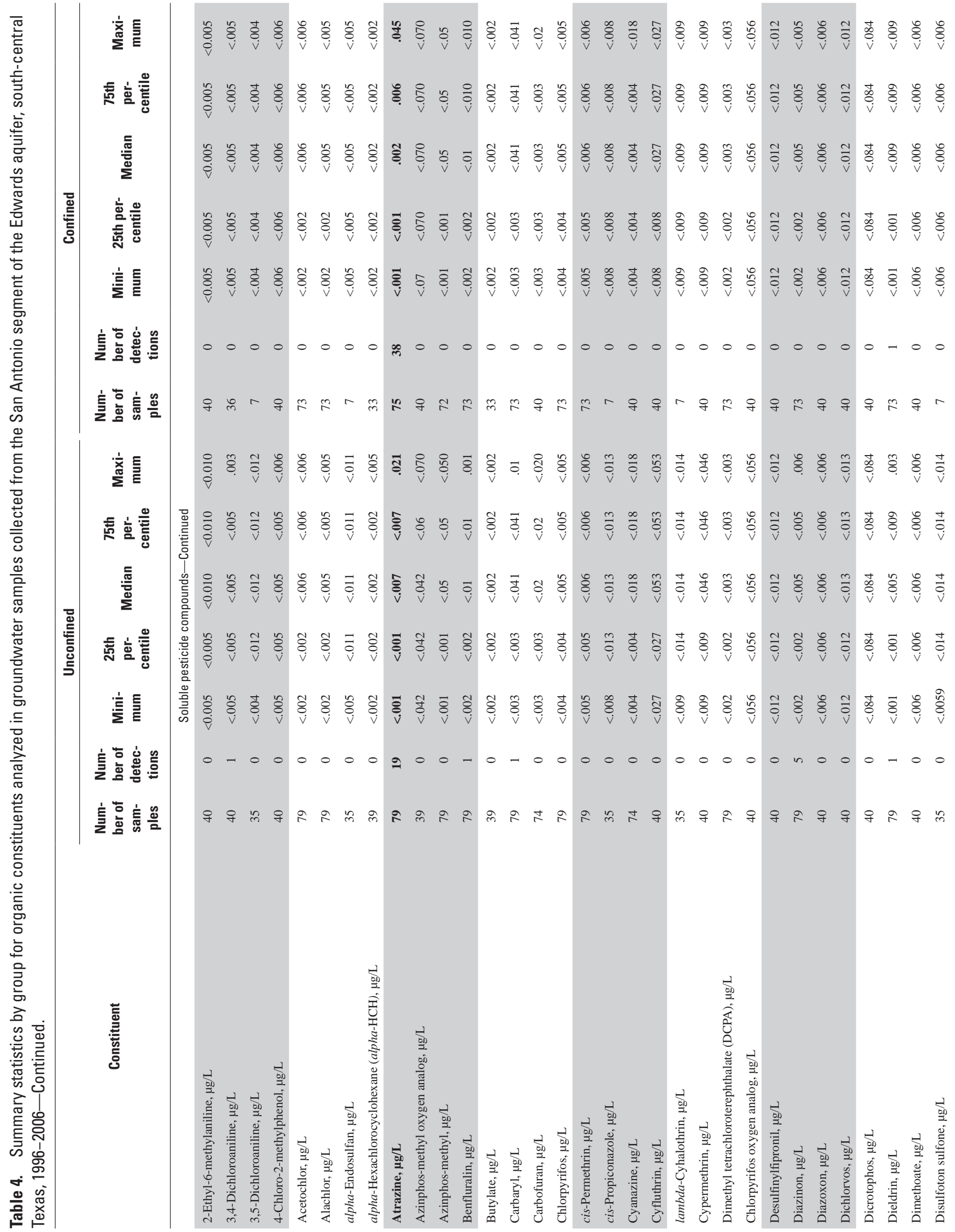




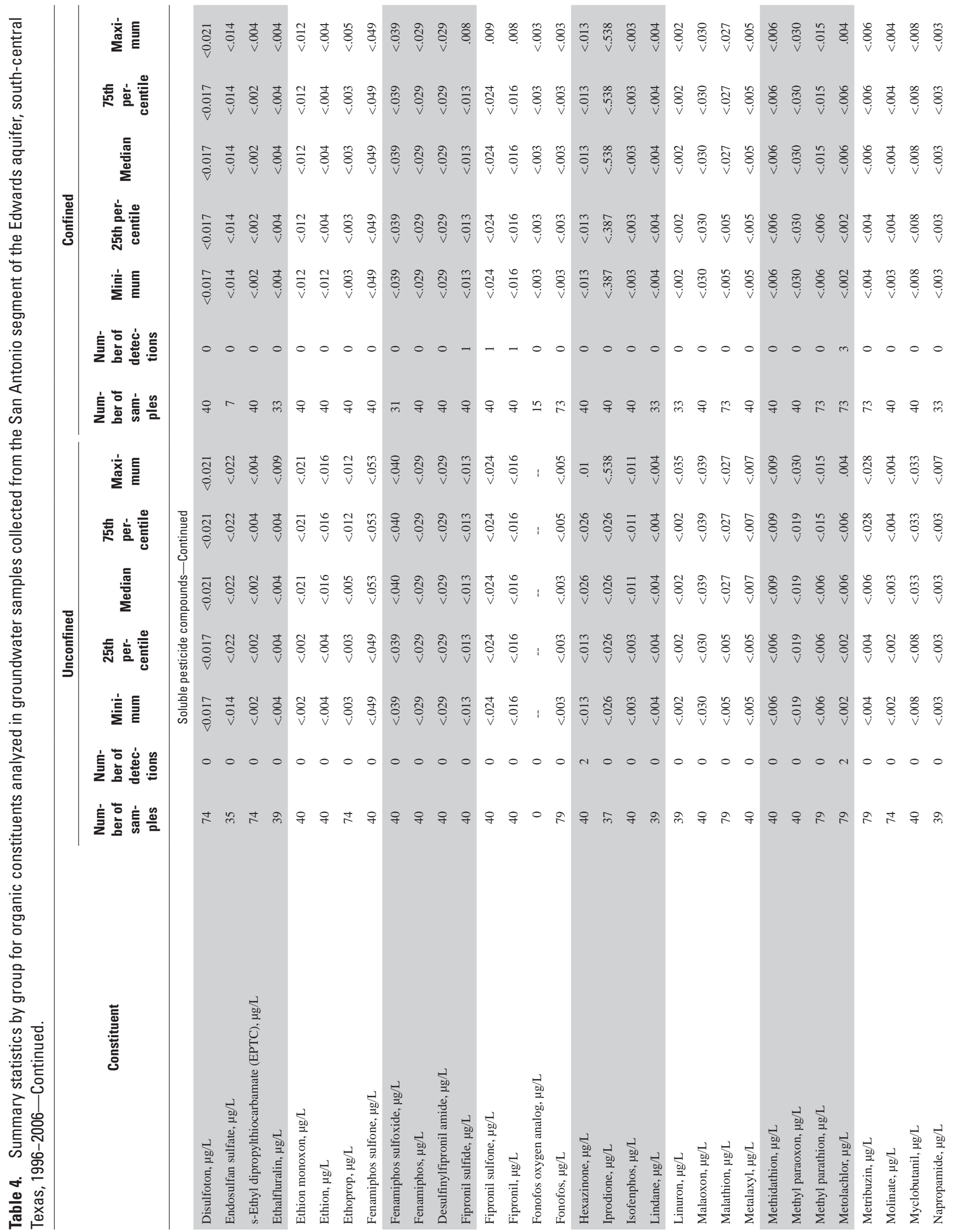




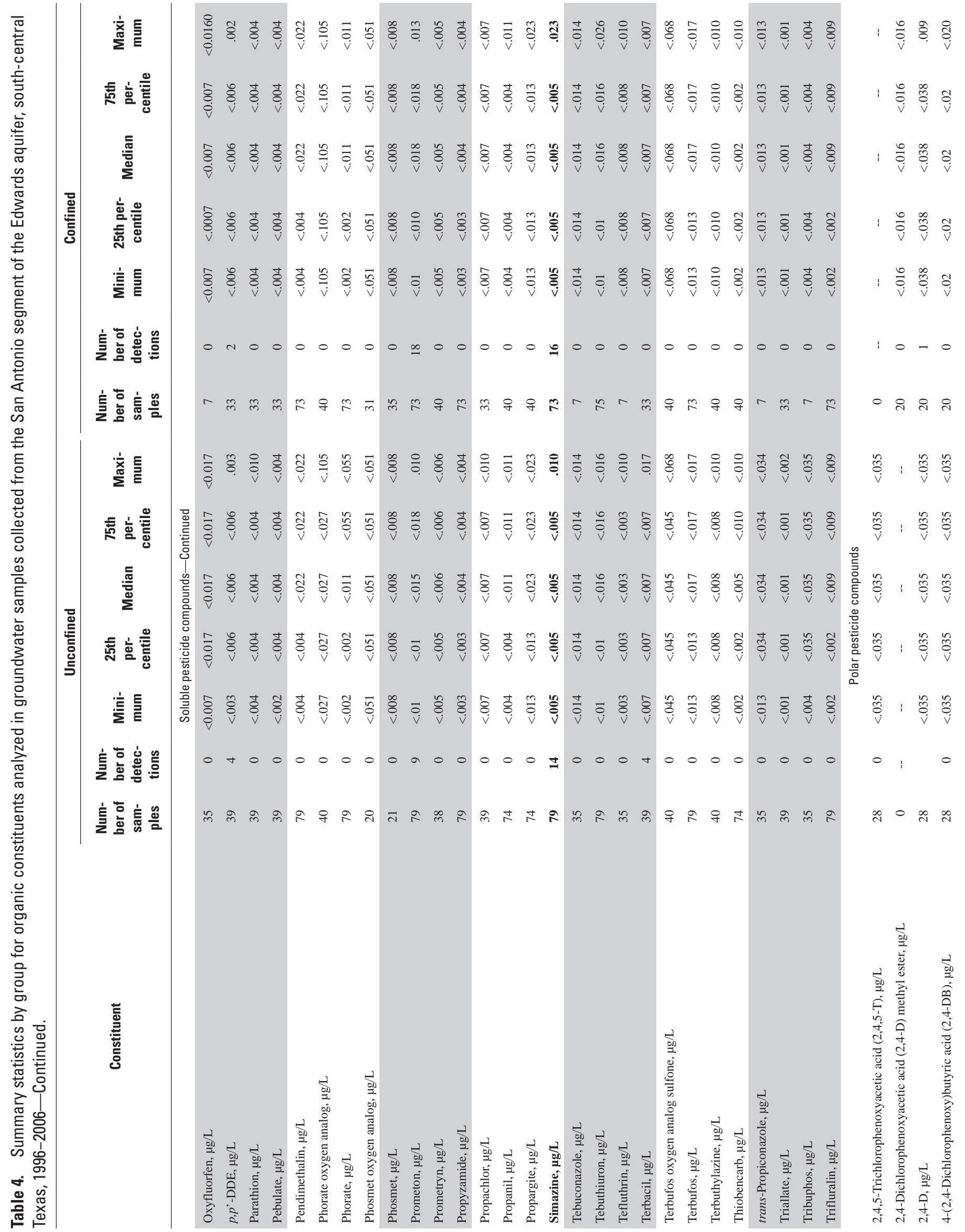




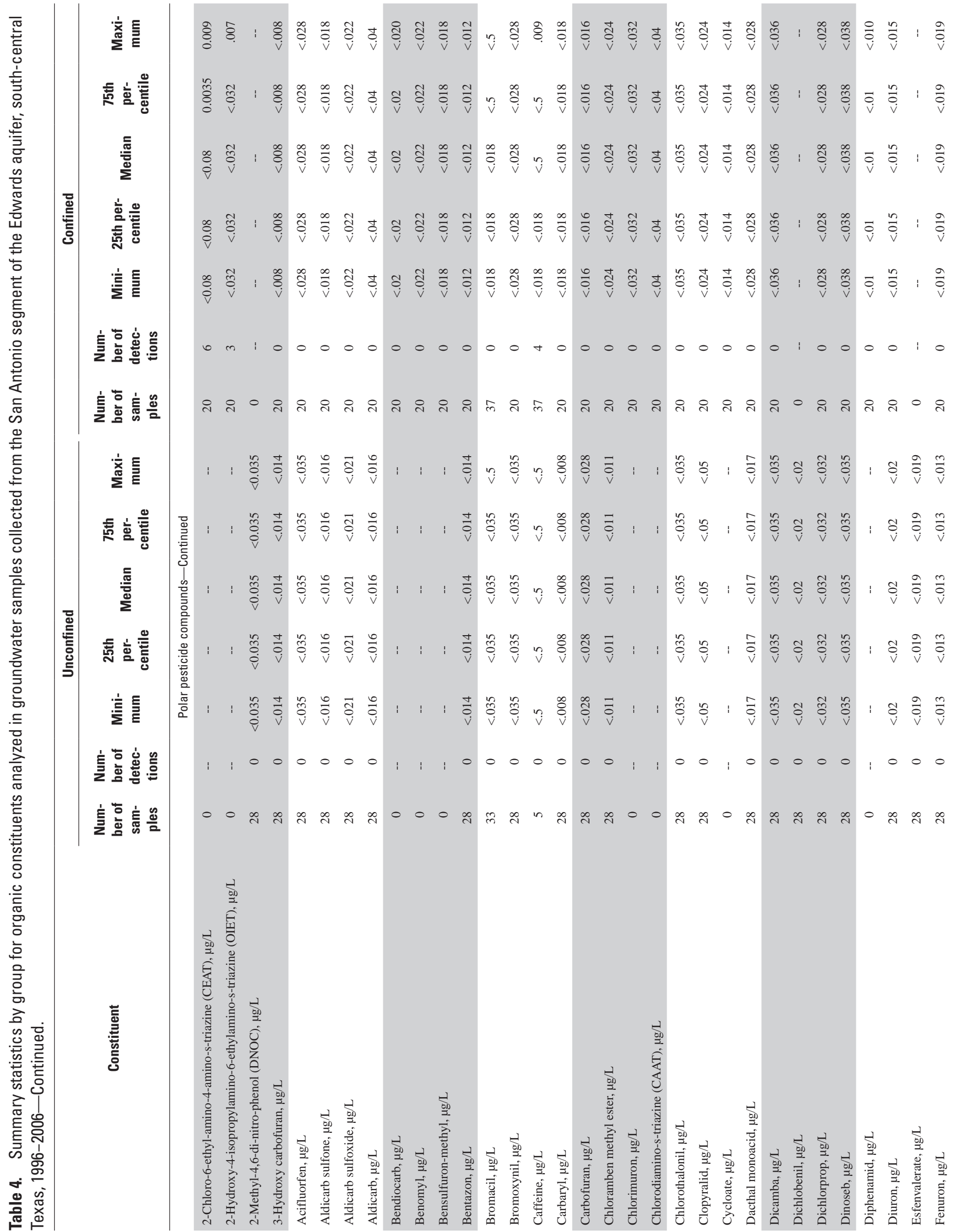




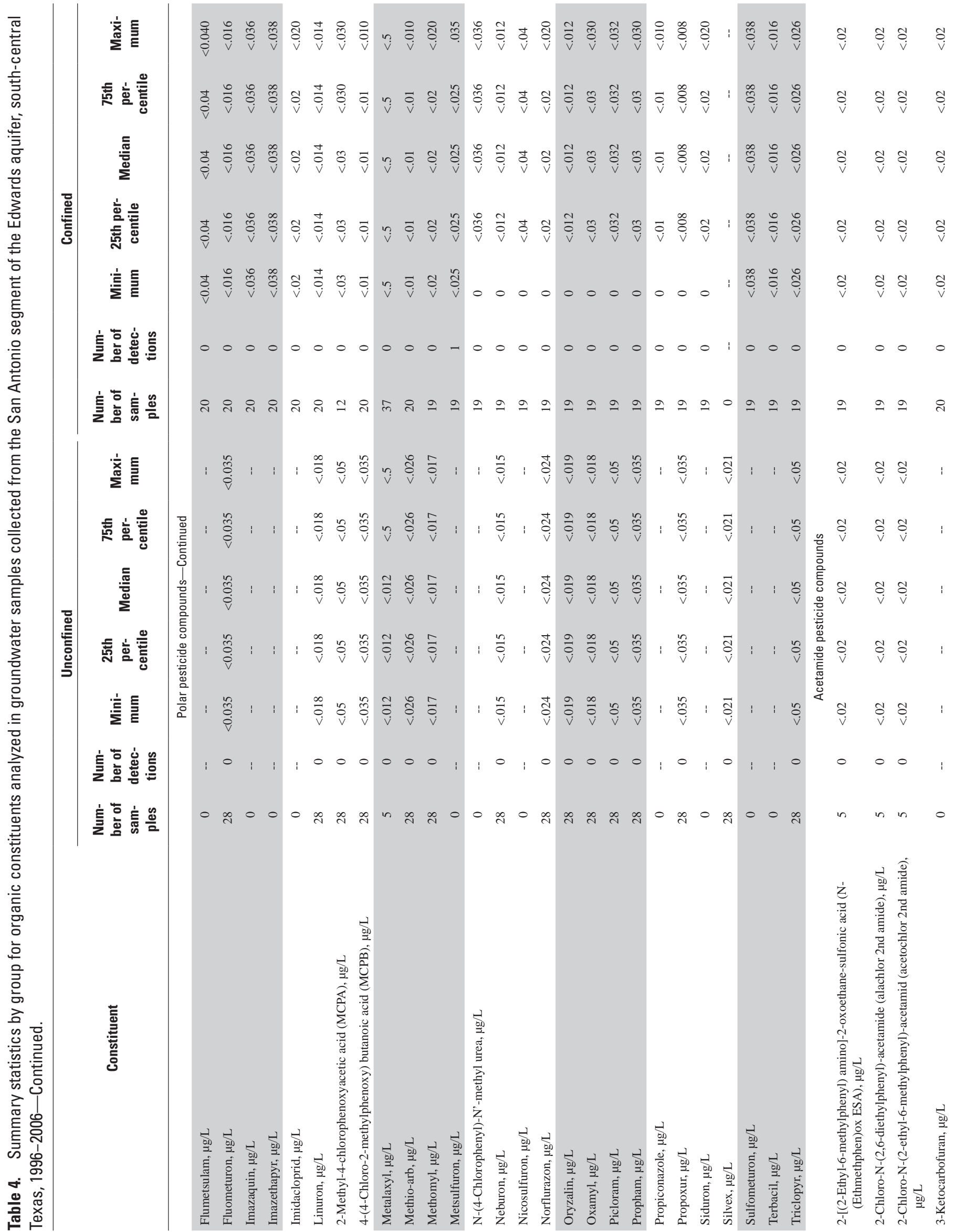




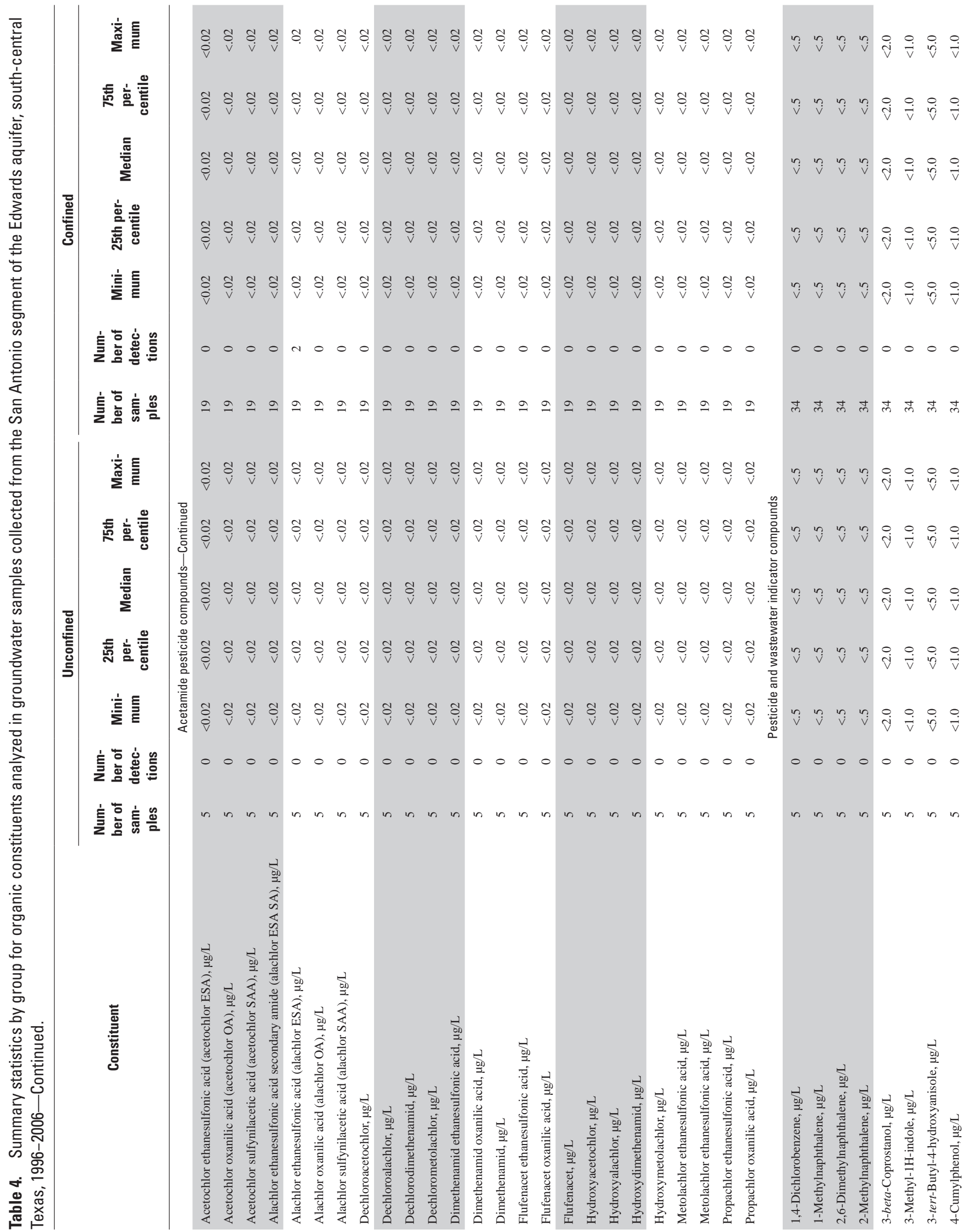




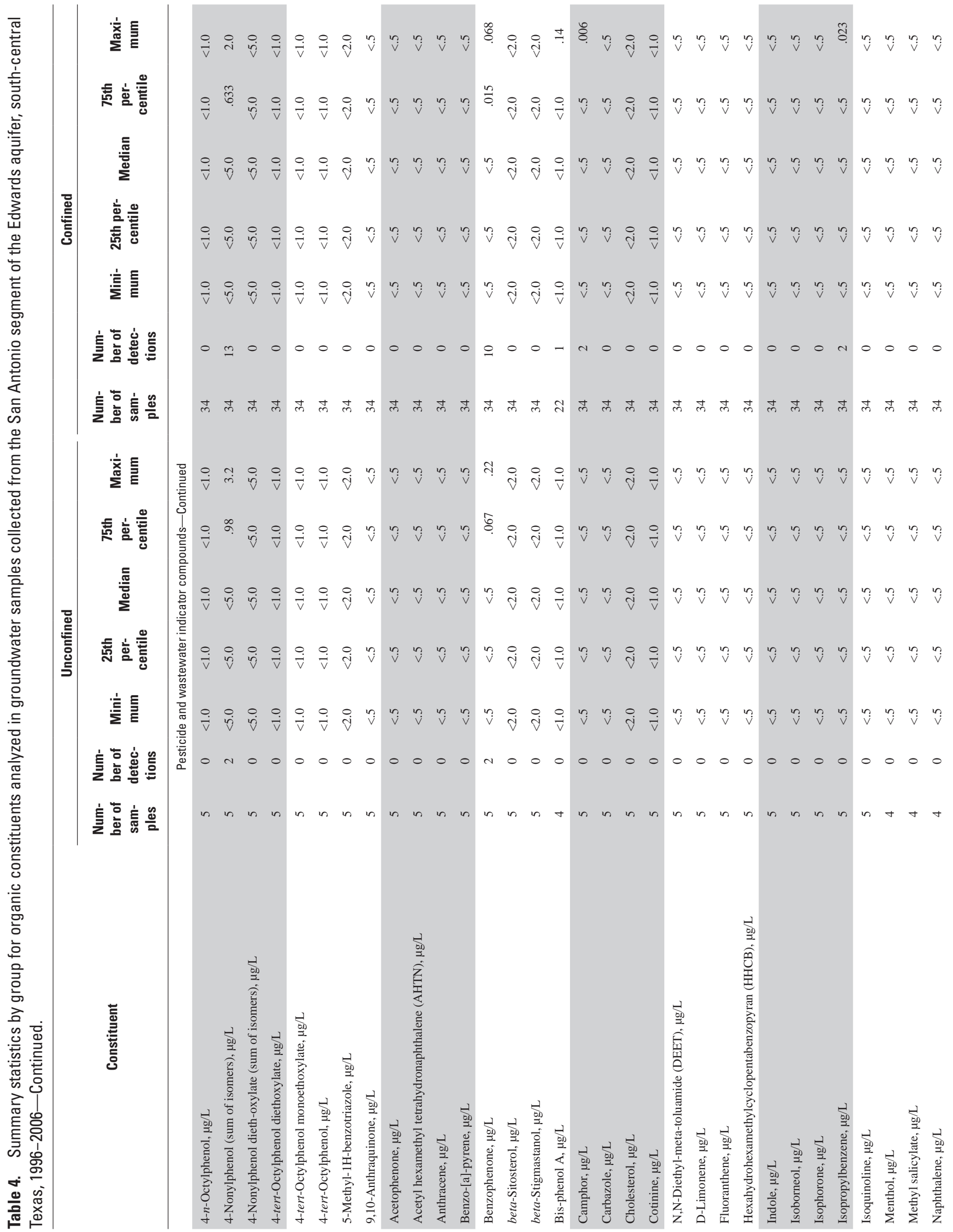




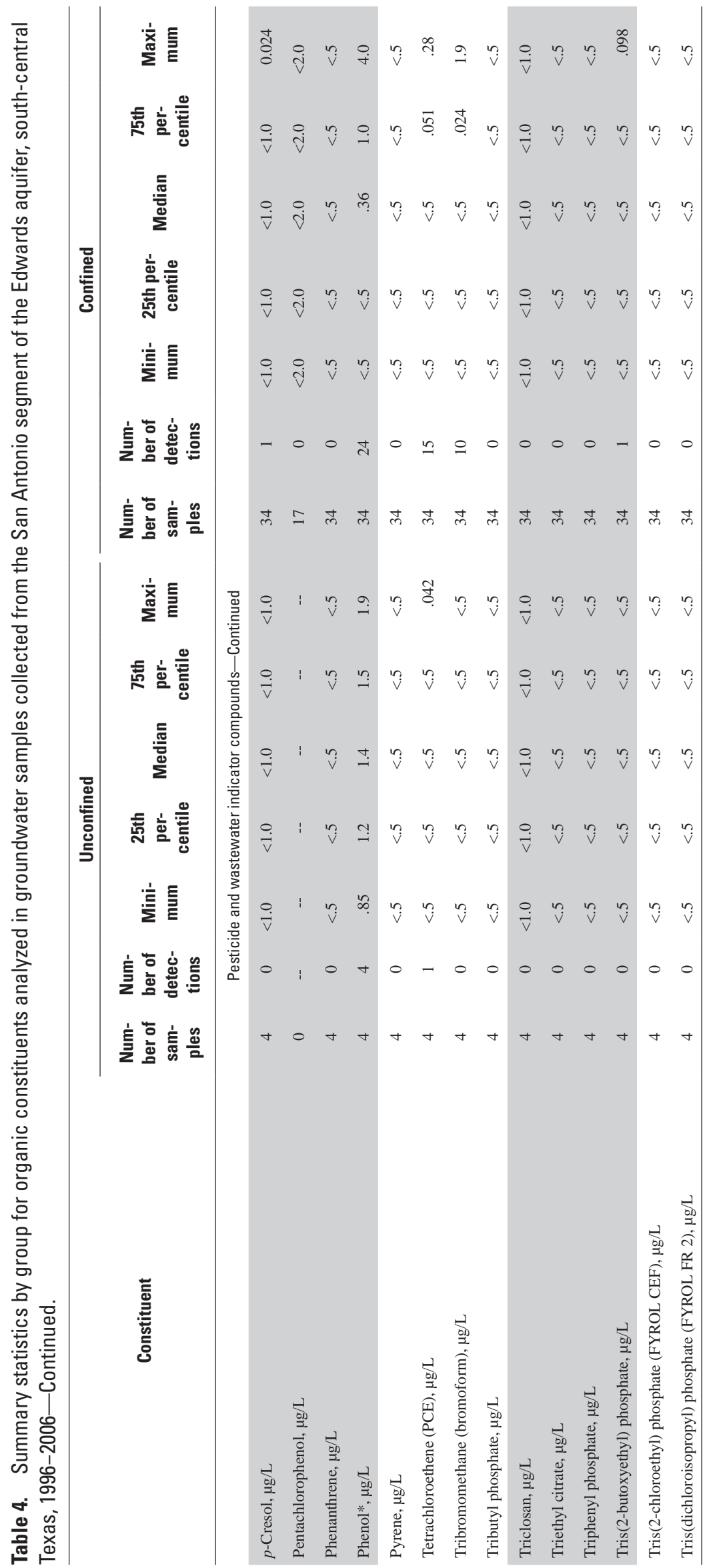


Table 5. Unconfined and confined category wells with historical water-quality data, San Antonio segment of the Edwards aquifer, south central Texas, 1957-2006.

[NAD 83, North American Datum of 1983; Mg, magnesium; Ca, calcium]

\begin{tabular}{|c|c|c|c|c|c|c|c|c|c|}
\hline \multirow{2}{*}{ Category } & \multirow{2}{*}{$\begin{array}{l}\text { State well } \\
\text { number }\end{array}$} & \multirow{2}{*}{ County } & \multirow{2}{*}{$\begin{array}{l}\text { Latitude } \\
\text { (decimal } \\
\text { degrees) } \\
\text { (NAD 83) }\end{array}$} & \multirow{2}{*}{$\begin{array}{l}\text { Longitude } \\
\text { (decimal } \\
\text { degrees) } \\
\text { (NAD 83) }\end{array}$} & \multirow{2}{*}{$\begin{array}{c}\text { Number of } \\
\text { samples } \\
\text { (one or more } \\
\text { constituents) }\end{array}$} & \multirow{2}{*}{$\begin{array}{c}\text { Range } \\
\text { of years } \\
\text { (collected } \\
\text { samples) }\end{array}$} & \multicolumn{3}{|c|}{$\begin{array}{c}\mathrm{Mg} / \mathrm{Ca} \\
\text { (molar ratio) }\end{array}$} \\
\hline & & & & & & & $\begin{array}{l}\text { Number of } \\
\text { samples }\end{array}$ & Median & $\begin{array}{c}\text { Interquartile } \\
\text { range }\end{array}$ \\
\hline Unconfined & AY-68-28-205 & Bexar & 29.58444 & -98.55722 & 16 & 1972-2004 & 11 & 0.162 & 0.198 \\
\hline Unconfined & AY-68-29-109 & Bexar & 29.58667 & -98.48806 & 29 & 1973-2006 & 26 & .170 & .377 \\
\hline Confined & DX-68-22-901 & Comal & 29.63550 & -98.26501 & 22 & 1974-2005 & 21 & .227 & .047 \\
\hline Confined & DX-68-23-303 & Comal & 29.71361 & -98.13444 & 27 & 1974-2003 & 26 & .361 & .079 \\
\hline Confined & DX-68-23-601 & Comal & 29.70800 & -98.14501 & 11 & 1974-2005 & 10 & .324 & .043 \\
\hline Confined & TD-69-40-403 & Medina & 29.43194 & -99.11611 & 11 & 1977-97 & 11 & .211 & .066 \\
\hline Confined & YP-69-45-405 & Uvalde & 29.32694 & -99.46806 & 21 & 1979-2004 & 19 & .324 & .041 \\
\hline Confined & YP-69-50-501 & Uvalde & 29.19083 & -99.83167 & 43 & 1959-2004 & 16 & .184 & .035 \\
\hline Confined & YP-69-50-506 & Uvalde & 29.20302 & -99.79922 & 20 & 1974-2004 & 20 & .155 & .035 \\
\hline
\end{tabular}


Table 6. Summary of age tracer data and interpreted apparent ages for groundwater samples collected from the San Antonio segment of the Edwards aquifer, south-central Texas, 1996-2006.

[Data summarized for all samples and for sample categories (shallow/urban unconfined and unconfined). CFC, chlorofluorocarbon; pg/kg, picograms per kilogram; pptv, parts per trillion per volume; yr, apparent age (year); $\mathrm{SF}_{6}$, sulfur hexafluoride; femtoMol/kg, femtomoles per kilogram]

\begin{tabular}{|c|c|c|c|c|c|c|c|c|}
\hline \multirow[b]{2}{*}{ Constituent } & \multicolumn{6}{|c|}{ All } & \multirow[b]{2}{*}{$\begin{array}{l}\text { Number } \\
\text { of } \\
\text { samples }\end{array}$} & Sh \\
\hline & $\begin{array}{c}\text { Number } \\
\text { of } \\
\text { samples }\end{array}$ & $\begin{array}{l}\text { Number of } \\
\text { detections or } \\
\text { measurements } \\
\text { (uncontaminat- } \\
\text { ed samples) }\end{array}$ & $\begin{array}{l}\text { Mini- } \\
\text { mum }\end{array}$ & Med & \multicolumn{2}{|c|}{$\begin{array}{l}\text { Maxi- } \\
\text { mum }\end{array}$} & & $\begin{array}{r}\text { Nur } \\
\text { detec } \\
\text { meas } \\
\text { s } \quad \begin{array}{r}\text { (unco } \\
\text { ed } s\end{array}\end{array}$ \\
\hline CFC-11, pg/kg & 82 & 28 & 0.1 & & \multicolumn{2}{|c|}{3.0} & \multicolumn{2}{|l|}{52} \\
\hline $\mathrm{CFC}-12, \mathrm{pg} / \mathrm{kg}$ & 82 & 7 & .1 & & \multicolumn{2}{|c|}{2.1} & \multicolumn{2}{|l|}{52} \\
\hline CFC-113, pg/kg & 82 & 48 & .01 & & \multicolumn{2}{|r|}{.5} & \multicolumn{2}{|l|}{52} \\
\hline CFC-11, pptv & 82 & 28 & 5.3 & 162 & \multicolumn{2}{|c|}{224.4} & \multicolumn{2}{|l|}{52} \\
\hline CFC-12, pptv & 82 & 7 & 19.5 & 421 & \multicolumn{2}{|c|}{53.5} & \multicolumn{2}{|l|}{52} \\
\hline CFC-113, pptv & 82 & 48 & 1.9 & 53 & \multicolumn{2}{|c|}{86.3} & \multicolumn{2}{|l|}{52} \\
\hline CFC-11, yr & 28 & 28 & 1956 & 1980 & \multicolumn{2}{|c|}{2003} & \multicolumn{2}{|l|}{2} \\
\hline CFC-12, yr & 7 & 7 & 1955 & 1986 & \multicolumn{2}{|c|}{1994} & \multicolumn{2}{|l|}{4} \\
\hline CFC-113, yr & 48 & 48 & 1961 & 1987 & \multicolumn{2}{|c|}{1998} & \multicolumn{2}{|l|}{26} \\
\hline CFC-11, number of years & 28 & 28 & 12.9 & 26 & \multicolumn{2}{|c|}{5.5} & \multicolumn{2}{|l|}{2} \\
\hline CFC-12, number of years & 7 & 7 & 9.4 & \multicolumn{2}{|c|}{2.3} & 1.6 & \multicolumn{2}{|l|}{4} \\
\hline CFC-113, number of years & 48 & 48 & 2.8 & 17.6 & 6 & 5.0 & 26 & \\
\hline $\mathrm{SF}_{6}$, femtoMol/kg & 22 & 20 & .4 & & .0 & 2.9 & 22 & \\
\hline $\mathrm{SF}_{6}, \mathrm{pptv}$ & 22 & 20 & .9 & & .0 & 5.8 & 22 & \\
\hline $\mathrm{SF}_{6}, \mathrm{yr}$ & 20 & 20 & 1981 & 1988 & 200 & & 20 & \\
\hline $\mathrm{SF}_{6}$, number of years & 20 & 20 & 1.2 & 18 & .7 & 5.2 & 20 & \\
\hline & & & Uncon & fined & & & & \\
\hline Constituent & $\begin{array}{c}\text { Number of } \\
\text { samples }\end{array}$ & $\begin{array}{r}\text { Number of } \\
\text { or meas } \\
\text { (uncontamin }\end{array}$ & $\begin{array}{l}\text { f detection } \\
\text { surements } \\
\text { lated samp }\end{array}$ & ns & $\begin{array}{l}\text { Mini- } \\
\text { mum }\end{array}$ & Median & & $\begin{array}{l}\text { Maxi- } \\
\text { mum }\end{array}$ \\
\hline $\mathrm{CFC}-11, \mathrm{pg} / \mathrm{kg}$ & 30 & & 26 & & 0.1 & 1.8 & & 2.8 \\
\hline $\mathrm{CFC}-12, \mathrm{pg} / \mathrm{kg}$ & 30 & & 3 & & .1 & .2 & & 1.4 \\
\hline CFC-113, pg/kg & 30 & & 22 & & .0 & .2 & & .3 \\
\hline CFC-11, pptv & 30 & & 26 & & 5.3 & 151.3 & & 23.8 \\
\hline CFC-12, pptv & 30 & & 3 & & 19.5 & 58.0 & & +21.9 \\
\hline CFC-113, pptv & 30 & & 22 & & 1.9 & 49.4 & & 79.0 \\
\hline CFC-11, yr & 26 & & 26 & & 1956 & 1980 & & 03 \\
\hline CFC-12, yr & 3 & & 3 & & 1955 & 1964 & & 86 \\
\hline CFC-113, yr & 22 & & 22 & & 1961 & 1986 & & 92 \\
\hline CFC-11, number of years & 26 & & 26 & & 2.1 & 27.10 & & 5.5 \\
\hline CFC-12, number of years & 3 & & 3 & & 2.3 & 42.73 & & 51.6 \\
\hline CFC-113, number of years & 22 & & 22 & & 14.5 & 2.60 & & 46.0 \\
\hline $\mathrm{SF}_{6}$, femtoMol/kg & 0 & & -- & & -- & -- & & -- \\
\hline $\mathrm{SF}_{6}, \mathrm{pptv}$ & 0 & & -- & & -- & -- & & -- \\
\hline $\mathrm{SF}_{6}, \mathrm{yr}$ & 0 & & -- & & -- & -- & & -- \\
\hline $\mathrm{SF}_{6}$, number of years & 0 & & -- & & -- & -- & & -- \\
\hline
\end{tabular}


Table 7. Summary of model-calculated particle-track information for groundwater sample categories, San Antonio segment of the Edwards aquifer, south-central Texas.

[Data summarized for all samples and for sample categories (shallow/urban unconfined, unconfined, and confined). yrs, years; mi, miles; ft/d, feet per day]

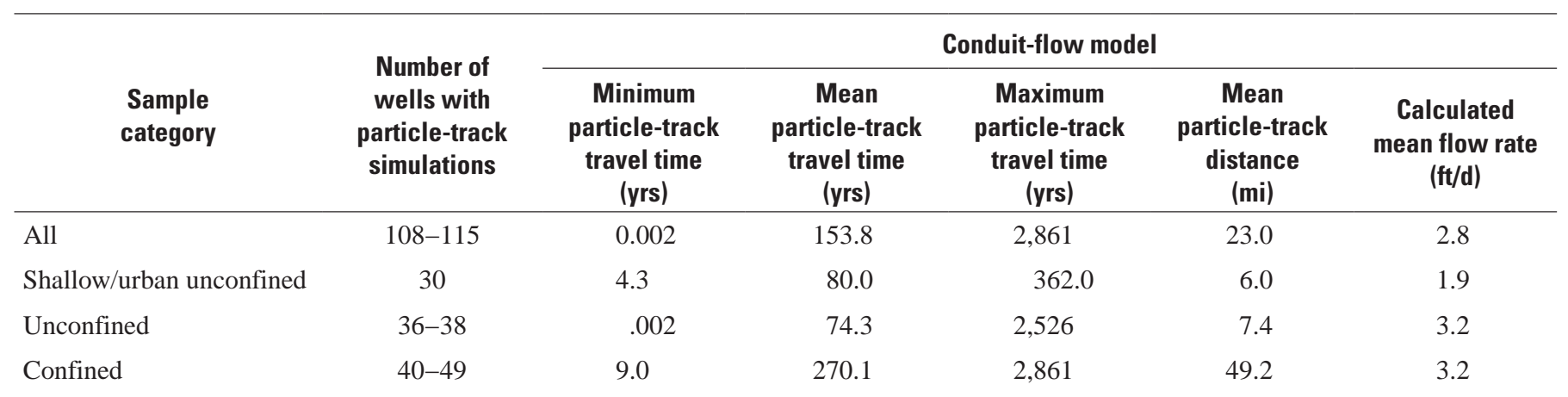

\begin{tabular}{|c|c|c|c|c|c|c|}
\hline \multirow[b]{2}{*}{$\begin{array}{l}\text { Sample } \\
\text { category }\end{array}$} & \multirow[b]{2}{*}{$\begin{array}{l}\text { Number of } \\
\text { wells with } \\
\text { particle-track } \\
\text { simulations }\end{array}$} & \multicolumn{5}{|c|}{ Diffuse-flow model } \\
\hline & & $\begin{array}{c}\text { Minimum } \\
\text { particle-track } \\
\text { travel time } \\
\text { (yrs) }\end{array}$ & $\begin{array}{c}\text { Mean } \\
\text { particle-track } \\
\text { travel time } \\
\text { (yrs) }\end{array}$ & $\begin{array}{l}\text { Maximum } \\
\text { particle-track } \\
\text { travel time } \\
\text { (yrs) }\end{array}$ & $\begin{array}{c}\text { Mean } \\
\text { particle-track } \\
\text { distance } \\
\text { (mi) }\end{array}$ & $\begin{array}{l}\text { Calculated } \\
\text { mean flow rate } \\
(\mathrm{ft} / \mathrm{d})\end{array}$ \\
\hline All & $108-115$ & 0.002 & 117.8 & 3,346 & 23.6 & 4.3 \\
\hline Shallow/urban unconfined & 30 & 5.1 & 47.2 & 341.4 & 4.8 & 4.0 \\
\hline Unconfined & $36-38$ & .002 & 68.8 & 3,346 & 7.5 & 4.9 \\
\hline Confined & 40-49 & 11.0 & 197.0 & 1,445 & 47.4 & 4.1 \\
\hline
\end{tabular}

Publishing support provided by Lafayette Publishing Service Center 

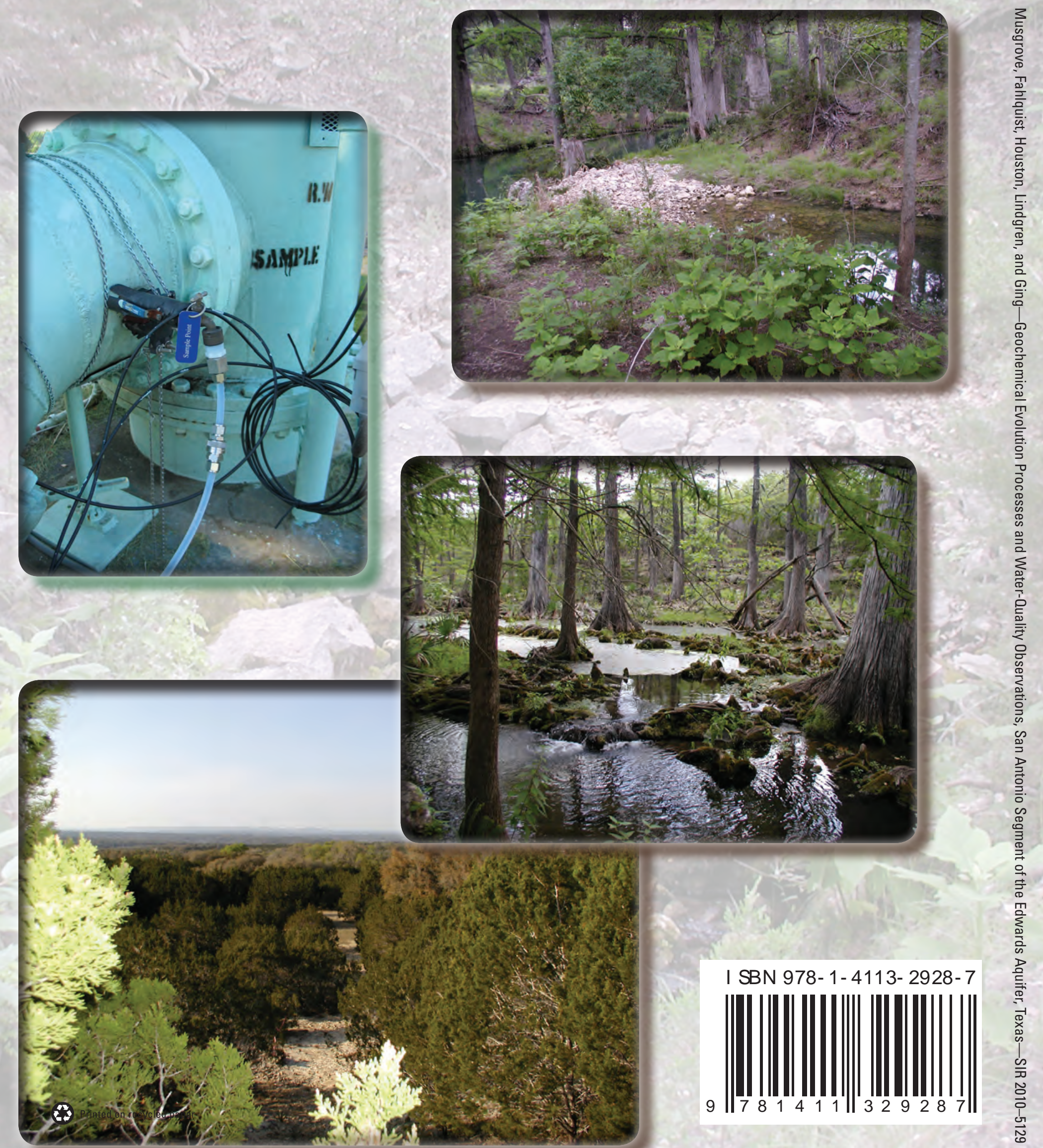